\title{
ENSINO DA TEMÁTICA SEGURANÇA DO PACIENTE NA FORMAÇÃO DOS PROFISSIONAIS DE SAÚDE NA PERSPECTIVA DE DISCENTES
}

\author{
Tese apresentada ao Programa de Pós-Graduação em \\ Gerenciamento em Enfermagem da Escola de \\ Enfermagem da Universidade de São Paulo para \\ obtenção do título de Doutora em Ciências da Saúde. \\ Área de concentração: Fundamentos e Práticas de \\ Gerenciamento em Enfermagem e em Saúde \\ Orientadora: Prof ${ }^{a}$. Dra ${ }^{\mathrm{a}}$. Marta Maria Melleiro
}

\section{São Paulo}


AUTORIZO A REPRODUÇÃO E DIVULGAÇÃO TOTAL OU PARCIAL DESTE TRABALHO, POR QUALQUER MEIO CONVENCIONAL OU ELETRÔNICO, PARA FINS DE ESTUDO E PESQUISA, DESDE QUE CITADA A FONTE.

Assinatura: Data:

\section{Catalogação na Publicação (CIP)}

\section{Biblioteca "Wanda de Aguiar Horta"}

Escola de Enfermagem da Universidade de São Paulo

\section{Garzin, Ana Claudia Alcântara}

Ensino da temática segurança do paciente na formação dos profissionais de saúde na perspectiva de discentes / Ana Claudia Alcântara Garzin. São Paulo, 2018. 268p.

Tese (Doutorado) - Escola de Enfermagem da Universidade de São Paulo.

Orientadora: Prof. ${ }^{a}$ Dr. ${ }^{\text {a }}$ Marta Maria Melleiro

Área de concentração: Fundamentos e práticas de gerenciamento em enfermagem e em saúde.

1. Segurança do paciente. 2. Qualidade da assistência à saúde. 3. Educação superior. 4. Currículo. I. Título. 
Nome: Ana Claudia Alcântara Garzin

Título: Ensino da temática segurança do paciente na formação de profissionais de saúde na perspectiva de discentes.

Tese apresentada ao Programa de Pós-Graduação em Gerenciamento em Enfermagem da Escola de Enfermagem da Universidade de São Paulo para obtenção do título de Doutora em Ciências da Saúde.

Aprovada em:

\section{Banca Examinadora}

Orientadora: Prof ${ }^{a}$. Dr ${ }^{\mathrm{a}}$. Marta Maria Melleiro

Instituição: Escola de Enfermagem da Universidade de São Paulo - EEUSP

Prof.Dr.:

Instituição:

Julgamento:

Assinatura:

Prof.Dr.:

Instituição:

Julgamento:

Assinatura:

Prof.Dr.:

Instituição:

Julgamento:

Assinatura:

Prof.Dr.:

Instituição:

Julgamento:

Assinatura:

Prof.Dr.:

Instituição:

Julgamento:

Assinatura: 



\section{DEDICATÓRIA}

Dedico este trabalho ao Felipe, meu filho amado! Todos os dias eu aprendo um pouquinho mais a ser mãe e me inspiro a tentar ser melhor, pois você é a melhor parte de mim!

Ao meu marido Ailton, companheiro em todos os momentos... seu amor, compreensão e apoio permitiram que este trabalho fosse concretizado. Obrigada por estar ao meu lado, por acreditar em mim e pela família que construímos com muito amor! 



\section{AGRADECIMENTOS}

Todos os dias sinto a presença de Deus em minha vida... pelo simples fato de estar viva, saudável e de ter formado uma linda família! Agradeço a Ele pelas graças abundantes, fé, proteção, por me iluminar e me dar tranquilidade para seguir em frente sem desanimar ao me deparar com as dificuldades.

Este trabalho não é resultado apenas de uma ideia e do esforço individual, pois nasceu a partir de significativas contribuições recolhidas em minha trajetória profissional e acadêmica. Foram tantas pessoas que apareceram e contribuíram para essa caminhada que é praticamente impossível nomear e agradecer sem cometer alguma injustiça... Obrigada a todos!

Meu sincero agradecimento à Prof ${ }^{a}$ Dra $^{a}$ Marta Maria Melleiro pelo carinho, respeito, bom humor e competência com que conduz suas orientações. Um exemplo a ser seguido!

Prof $^{-}$Dr $^{a}$ Daisy Maria Rizatto Tronchin, que sempre esteve presente nesta trajetória acadêmica, obrigada pelas suas contribuições!

Manifesto minha gratidão por toda a colaboração e acolhimento dos funcionários e professores do Departamento de Orientação Profissional - EEUSP.

Agradeço à IES que permitiu ser cenário deste estudo e aos coordenadores dos cursos participantes que colaboraram nas etapas desta pesquisa.

Aos discentes e futuros profissionais da área da saúde que aceitaram participar desta pesquisa, obrigada! Sem vocês este estudo não seria possível.

Por fim, agradeço à minha família, que me apoia e compartilha comigo o amor e a alegria deste momento! 

O Senhor é o meu pastor, nada me faltará.



Deitar-me faz em verdes pastos, guia-me mansamente a águas tranquilas.

Refrigera a minha alma; guia-me pelas veredas da justiça, por amor do seu nome.

Ainda que eu andasse pelo vale da sombra da morte, não temeria mal algum, porque Tu estás comigo; a tua vara e o teu cajado me consolam.

Preparas uma mesa perante a mim na presença dos meus inimigos, unges a minha cabeça com óleo, o meu cálice transborda.

Certamente que a bondade e a misericórdia divina me seguirão todos os dias da minha vida; e habitarei na casa do Senhor por longos dias. 

Garzin, ACA. Ensino da temática segurança do paciente na formação de profissionais de saúde na perspectiva de discentes [tese]. São Paulo: Escola de Enfermagem, Universidade de São Paulo; 2018.

\section{RESUMO}

Introdução: A segurança do paciente é reconhecida como uma dimensão intrínseca da qualidade e responsabilidade de todos os envolvidos na assistência à saúde, devendo, portanto, ser amplamente integrada à formação dos profissionais que atuam nessa área. Objetivos: Compreender a percepção de discentes de graduação de uma Instituição de Ensino Superior (IES), integrantes dos cursos de enfermagem, medicina, fisioterapia, farmácia, nutrição, terapia ocupacional e biomedicina, acerca do ensino da temática segurança do paciente; propor uma intervenção para a inserção da temática segurança do paciente, de forma interdisciplinar, nos cursos da área da saúde. Percurso metodológico: Trata-se de uma pesquisa qualitativa, com delineamento exploratório-descritivo, na modalidade estudo de caso, desenvolvida em uma IES privada, localizada no município de São Paulo, cujos participantes foram 21 discentes dos cursos supracitados. Após a aprovação nos Comitês de Ética em Pesquisa e concordância formal de cada participante, os dados foram coletados no período de agosto a outubro de 2016, por meio de entrevistas semiestruturadas, conduzidas com o apoio de um material ilustrativo elaborado a partir dos 11 tópicos para segurança do paciente elencados no Guia Curricular da World Health Organization. Os dados foram transformados em narrativas validadas pelos participantes e, posteriormente, analisadas quanto ao seu conteúdo, de acordo com Bardin. O referencial teórico da interdisciplinaridade de Edgar Morin foi adotado para fundamentar a análise interpretativa dos achados. Resultados: Emergiram das narrativas sete categorias, a saber: inserção da temática segurança do paciente durante a formação acadêmica; falibilidade humana e o aprendizado acerca dos riscos e erros assistenciais; atuação da equipe de saúde e a inclusão do paciente como parceiro nas tomadas de decisão; sistemas organizacionais e sua interface com a qualidade assistencial; protocolos como ferramentas para segurança do paciente; segurança e qualidade como elementos fundamentais na cadeia medicamentosa; e abordando a temática segurança do paciente: estratégias e metodologias de ensino. A análise interpretativa nos remeteu à necessidade da inserção formal da segurança do paciente, articulada com as diferentes disciplinas nos cursos de graduação elencados neste estudo, bem como da capacitação dos docentes para incorporá-la no processo ensino-aprendizagem. Considerações finais: O estudo propiciou a compreensão da percepção dos discentes de graduação acerca da abordagem da segurança do paciente durante a sua formação profissional, permitiu destacar a falta de uniformidade na maneira com a qual essa temática está inserida nos diferentes cursos e ainda a necessidade de sensibilizar os docentes para integrar a segurança do paciente de forma contextualizada nas disciplinas teóricas ou técnicas sob sua responsabilidade, de modo que contribua para a incorporação de atitudes e práticas conscientes e colaborativas por parte dos futuros profissionais, para o fortalecimento da cultura de segurança e por melhores resultados assistenciais nas diferentes áreas de atuação em saúde.

PALAVRAS-CHAVE: Segurança do paciente. Qualidade da assistência à saúde. Educação superior. Currículo. 

Garzin, ACA. Teaching of patient safety issues in the training of health professionals from students' perspective [thesis]. São Paulo: Nursing school, University of São Paulo; 2018.

\section{ABSTRACT}

Introduction: Patient safety is recognized as an intrinsic dimension of the quality and responsibility of all those involved in health care and should therefore be broadly integrated into the training of professionals working in this area. Aims: To understand the perception of undergraduate students of a Higher Education Institution (HEI), members of nursing, medicine, physiotherapy, pharmacy, nutrition, occupational therapy and biomedicine courses on the teaching of patient safety; to propose an intervention for the insertion of the theme of patient safety, in an interdisciplinary way, in the courses of the health area. Methodological approach: It is a qualitative research, with an exploratory-descriptive design, in the case study modality, developed in a private $\mathrm{HEl}$, located in the city of São Paulo. The participants were 21 students from the courses mentioned above. After approval by the Research Ethics Committees and formal agreement of each participant, the data were collected from August to October 2016, through semi-structured interviews, conducted with the support of an illustrative material elaborated from the 11 topics for patient safety listed in the World Health Organization Curriculum Guide. The data were transformed into narratives validated by the participants and then analyzed for their content, according to Bardin. Edgar Morin's theoretical framework of interdisciplinarity was adopted to support the interpretative analysis of the findings. Results: Seven categories emerged from the narratives, namely: insertion of the theme of patient safety during the academic formation; human fallibility and learning about care risks and errors; performance of the health team and the inclusion of the patient as a partner in decision making; organizational systems and their interface with the quality of care; protocols as tools for patient safety; safety and quality as key elements in the drug chain; and addressing the topic of patient safety: strategies and teaching methodologies. The interpretative analysis referred to the need for formal insertion of patient safety, articulated with the different disciplines in the undergraduate courses listed in this study, as well as the training of teachers to incorporate it into the teaching-learning process. Final considerations: The study provided an understanding of undergraduate students' perception about the patient safety approach during their professional training, highlighting the lack of uniformity in the way in which this theme is inserted in the different courses and also the need to sensitize teachers to integrate patient safety in a contextualized way in the theoretical or technical disciplines under their responsibility, so that it contributes to the incorporation of conscious and collaborative attitudes and practices on the part of the future professionals, for the strengthening of safety culture and for better care results in different areas of health care.

KEYWORDS: Patient safety. Quality of health care. Education, Higher. Curriculum. 

Garzin, ACA. Enseñanza de la temática seguridad del paciente en la formación de los profesionales de la salud en la perspectiva de discentes [tesis]. São Paulo: Escuela de Enfermería, Universidad de São Paulo; 2018.

\section{RESUMEN}

Introducción: Se reconoce la seguridad del paciente como una dimensión intrínseca de la calidad, siendo responsabilidad de todos los envueltos en el cuidado de la salud, por lo que se debe integrar a la formación de los profesionales que actúan en esa área. Objetivos: Comprender la percepción que los discentes de graduación de una Institución de Enseñanza Superior (IES), los integrantes de los cursos de enfermería, medicina, fisioterapia, farmacia, nutrición, terapia ocupacional y biomedicina tienen, acerca de la enseñanza de la temática seguridad del paciente; proponer una intervención para inserir la temática seguridad del paciente, de forma interdisciplinar, en los cursos del área de salud. Trayecto metodológico: se trata de una investigación cualitativa, con delineamiento exploratorio-descriptivo, en la modalidad estudio de caso, desarrollada en una IES privada, ubicada en el municipio de São Paulo, en la que participaron 21 discentes de los cursos citados. Después de ser aprobada por los Comités de Ética en Pesquisas y la concordancia formal de cada participante, los datos fueron recolectados en el periodo de agosto a octubre de 2016, por medio de entrevistas semiestructuradas, conducidas con apoyo de un material ilustrativo elaborado a partir de los 11 tópicos para seguridad del paciente referidos en la Guía Curricular de la World Health Organization. Los datos fueron transformados en narrativas validadas por los participantes $y$, posteriormente, su contenido analizado, de acuerdo con Bardin. El referencial teórico de la interdisciplinaridad de Edgar Morin se adoptó para fundamentar el análisis interpretativo de los hallazgos. Resultados: Emergieron de las narrativas siete categorías a seguir: inserción de la temática seguridad del paciente durante la formación académica; falibilidad humana y el aprendizaje de los riesgos y errores en el cuidado; actuación del equipo de salud y la inclusión del paciente al tomar las decisiones; sistemas organizativos y su interface con la calidad asistencial; protocolos como herramientas para la seguridad del paciente; seguridad y calidad como elementos fundamentales en la cadena medicamentosa; y abordando la temática seguridad del paciente: estrategias y metodologías de enseñanza. El análisis interpretativo nos remitió a la necesidad de inserir formalmente la seguridad del paciente, articulándola con las diferentes disciplinas en los cursos de graduación mencionados en este estudio, así como la necesidad de capacitar a los docentes, para poder incorporarla en el proceso enseñanza-aprendizaje. Consideraciones finales: El estudio propició comprender la percepción que los discentes de graduación tienen acerca del abordaje de la seguridad del paciente durante su formación profesional, permitió destacar la falta de uniformidad en la manera como esta temática está inserida en los diferentes cursos y la necesidad de sensibilizar a los docentes para integrar la seguridad del paciente de forma contextualizada en las disciplinas teóricas o técnicas bajo su responsabilidad, de modo que pueda contribuir a que los profesionales incorporen actitudes y prácticas conscientes y colaborativas para así fortalecer la cultura de seguridad y mejorar los resultados asistenciales en las diferentes áreas de la salud.

PALABRAS-CLAVES: Seguridad del paciente. Calidad de la atención de salud. Educación superior. Curriculum. 



\section{LISTA DE ILUSTRAÇÕES}

Figura 1 - Esquema demonstrativo da trajetória percorrida no desenvolvimento do estudo. São Paulo, 2018

Figura $2 \quad-\quad$ Esquema demonstrativo dos principais tipos de erros

Figura 3 - Etapas para a transposição da linguagem oral para a escrita realizadas em cada entrevista

Figura 4 - Esquema para operacionalização da capacitação docente e inserção da segurança do paciente nas matrizes curriculares. São Paulo, 2018

Figura 5 - Modelo de ficha para levantamento das informações de 233 cada disciplina dos cursos de graduação. São Paulo, 2018 



\section{LISTA DE QUADROS}
Quadro 1 - Áreas e estratégias de atuação da REBRAENSP
Quadro 2 - Recomendação para abordagem de sistemas de segurança
Quadro 3 - Objetivos propostos pelo Guia Curricular da WHO
Quadro 4 - Domínios do aprendizado e comportamentos desenvolvidos por meio da educação interdisciplinar em saúde

Quadro 5 - Aspectos gerais dos cursos de graduação participantes deste estudo. São Paulo, 2018
Quadro 6 - Proposta para o desenvolvimento da capacitação docente sobre segurança do paciente, 2018

Quadro 7 - Proposta para o desenvolvimento dos encontros de 229 grupo focal com os docentes. São Paulo, 2018
Quadro 8 - Proposta para o desenvolvimento da revisão das matrizes curriculares dos cursos de graduação na área da saúde. São Paulo, 2018 231

Quadro 9 - Proposta de inserção dos tópicos de segurança do 234 paciente nas matrizes curriculares. São Paulo, 2018 



\section{LISTA DE SIGLAS}

ACSQHC Australian Council on Safety and Quality in Health Care

AMA Assistência Médica Ambulatorial

ANVISA Agência Nacional de Vigilância Sanitária

APSEF Australian Patient Safety Education Framework

CAPS Centro de Atenção Psicossocial

CCIH Comissão de Controle de Infecção Hospitalar

CNPq Conselho Nacional de Desenvolvimento Científico e Tecnológico

DCNs Diretrizes Curriculares Nacionais

EEUSP Escola de Enfermagem da Universidade de São Paulo

IES Instituições de Ensino Superior

IOM Institute of Medicine

IRAS Infecções Relacionadas à Assistência à Saúde

NHS National Health Service

NPSA National Patient Safety Agency

NPSF National Patient Safety Foundation 


$\begin{array}{ll}\text { NSP } & \text { Núcleo de Segurança do Paciente } \\ \text { OMS } & \text { Organização Mundial da Saúde } \\ \text { POP } & \text { Procedimento Operacional Padrão } \\ \text { PNSP } & \text { Programa Nacional de Segurança do Paciente } \\ \text { PPGEn } & \begin{array}{l}\text { Programa de Pós-Graduação em Gerenciamento } \\ \text { RDC }\end{array} \\ \text { REBRAENSP } & \text { Rede Brasileira de Enfermagem e Segurança do Paciente } \\ \text { SAMU } & \text { Serviço de Atendimento Móvel de Urgência } \\ \text { SUS } & \text { Sistema Único de Saúde } \\ \text { UBS } & \text { Unidade Básica de Saúde } \\ \text { UTI } & \text { Unidade de Terapia Intensiva } \\ \text { WHO } & \end{array}$




\section{SUMÁRIO}

CONTEXTUALIZAÇÃO DA TEMÁTICA

OBJETIVOS DO ESTUDO

EIXO NORTEADOR

\section{CAPÍTULO 1}

A TEMÁTICA SEGURANÇA DO PACIENTE.

1.1 A FORMAÇÃO DOS PROFISSIONAIS DE SAÚDE NO QUE TANGE À SEGURANÇA DO PACIENTE: A ESTRATÉGIA PROPOSTA PELA WHO ...53

\section{CAPÍTULO 2}

ABORDAGEM INTERDISCIPLINAR E SUA INTERFACE COM A SEGURANÇA DO PACIENTE.

\section{CAPÍTULO 3}

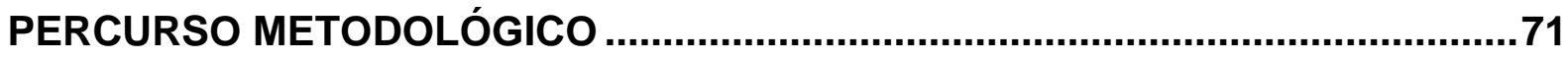

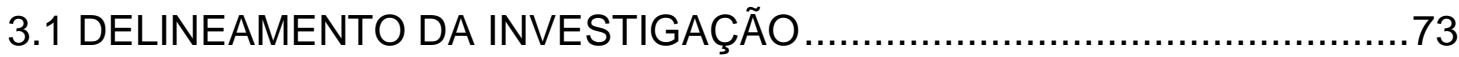

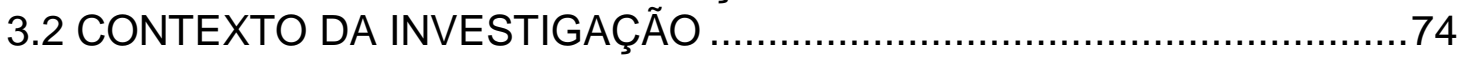

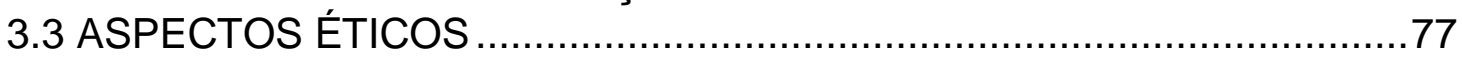

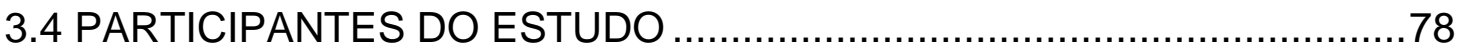

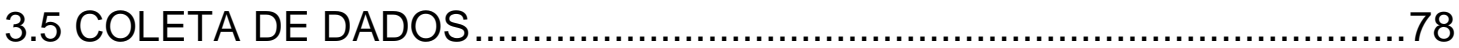

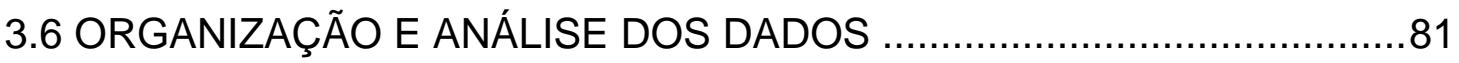

\section{CAPÍTULO 4}

NARRATIVAS

\section{CAPÍTULO 5}

CONSTRUÇÃO DAS CATEGORIAS

5.1 INSERÇÃO DA TEMÁTICA SEGURANÇA DO PACIENTE DURANTE

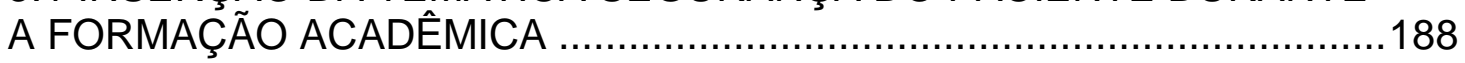

5.2 FALIBILIDADE HUMANA E O APRENDIZADO ACERCA DOS

RISCOS E ERROS ASSISTENCIAIS

5.3 ATUAÇÃO DA EQUIPE DE SAÚDE E A INCLUSÃO DO PACIENTE COMO PARCEIRO NAS TOMADAS DE DECISÃO. 
5.4 SISTEMAS ORGANIZACIONAIS E SUA INTERFACE COM A QUALIDADE ASSISTENCIAL .......................................................... 200

5.5 PROTOCOLOS COMO FERRAMENTAS PARA SEGURANÇA

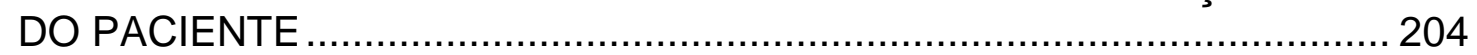

5.6 SEGURANÇA E QUALIDADE COMO ELEMENTOS FUNDAMENTAIS

NA CADEIA MEDICAMENTOSA ……............................................ 208

5.7 ABORDANDO A TEMÁTICA SEGURANÇA DO PACIENTE:

ESTRATÉGIAS E METODOLOGIAS DE ENSINO

CAPÍTULO 6

ANÁLISE INTERPRETATIVA À LUZ DO REFERENCIAL TEÓRICO 215

CAPÍTULO 7

INSERÇÃO DA TEMÁTICA SEGURANÇA DO PACIENTE: PROPOSTA DE INTERVENÇÃO.

PERSPECTIVAS E DESAFIOS FRENTE À INSERÇÃO DA SEGURANÇA DO PACIENTE NA FORMAÇÃO DOS PROFISSIONAIS DE SAÚDE:

CONSIDERAÇÕES FINAIS

REFERÊNCIAS 239

APÊNDICES. 253

APÊNDICE A - TERMO DE CONSENTIMENTO LIVRE E

ESCLARECIDO

APÊNDICE B - ROTEIRO PARA REALIZAÇÃO DAS ENTREVISTAS

COM DISCENTES

APÊNDICE C - MATERIAL ILUSTRATIVO ELABORADO PELA

PESQUISADORA A PARTIR DO GUIA CURRICULAR DE SEGURANÇA DO

PACIENTE: EDIÇÃO MULTIPROFISSIONAL

ANEXO 1 - APROVAÇÃO PELO COMITÊ DE ÉTICA EM PESQUISA INSTITUIÇÃO PROPONENTE. 
CONTEXTUALIZAÇÃO DA TEMÁTICA

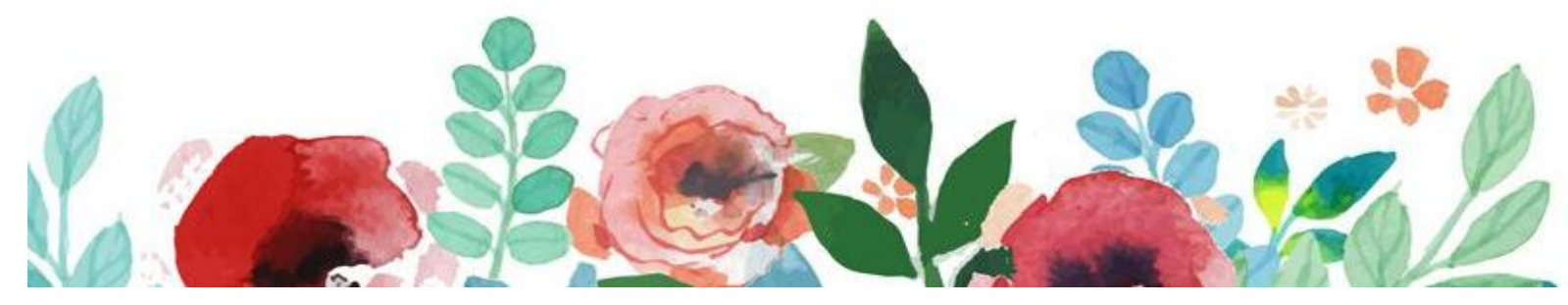



"Sem a curiosidade que me move, que me inquieta, que me insere na busca, não aprendo nem ensino."

Paulo Freire

Desde a graduação em enfermagem, a área de gerenciamento dos serviços de saúde e de enfermagem sempre despertou o meu interesse, pois a organização do trabalho e dos recursos têm como finalidade propiciar assistência à saúde com humanização, qualidade e segurança e, portanto, o gerenciamento e a prática assistencial não podem ocorrer de forma dissociada.

Com o objetivo de compreender e verticalizar o conhecimento sobre a avaliação da qualidade e segurança do paciente, desde 2008 integro o Grupo de Pesquisa da Escola de Enfermagem da Universidade de São Paulo (EEUSP), denominado "Qualidade e Avaliação de Serviços de Saúde e de Enfermagem", cadastrado no Conselho Nacional de Pesquisa e Desenvolvimento Tecnológico (CNPq).

Em 2011 defendi o mestrado com a análise da percepção dos trabalhadores de enfermagem de uma empresa de medicina diagnóstica acerca da qualidade da assistência de enfermagem prestada e seus fatores intervenientes.

Após a titulação, iniciei minha atuação como docente no curso de graduação em enfermagem em uma universidade privada, nas disciplinas relacionadas ao gerenciamento em enfermagem no ano de 2012 e, além das disciplinas teóricas ministradas na graduação em enfermagem, acompanho estágio supervisionado em gestão e de ensino clínico, o que me proporciona a interação com discentes de outros cursos da área da saúde.

Ao observar a prática ou ao participar, junto aos discentes, das ações interdisciplinares no campo de estágio, percebo que os conceitos qualidade e segurança do paciente não estão sendo difundidos de forma homogênea nem articulados entre os diferentes cursos na área da saúde, bem como o trabalho interdisciplinar não ocorre com a frequência e a naturalidade esperadas.

Dessa forma, somam-se às minhas percepções decorrentes das atividades docentes as reflexões advindas do grupo de pesquisa acima mencionado e da participação, durante o período de 2014 a 2016, do Núcleo das Escolas de 
Graduação em Enfermagem do Polo São Paulo, da Rede Brasileira de Enfermagem e Segurança do Paciente (REBRAENSP), as quais me impulsionaram aprofundar na temática segurança do paciente, no que diz respeito à formação dos profissionais de saúde.

A segurança do paciente é reconhecida como uma dimensão intrínseca da qualidade da assistência à saúde e, portanto, ambos os assuntos devem ser progressivamente integrados na formação dos profissionais de saúde de maneira interdisciplinar.

Contudo, observa-se que a introdução da interdisciplinaridade na pauta das discussões entre os docentes das Instituições de Ensino Superior (IES), especialmente naquelas voltadas para a formação na área da saúde, ainda é incipiente.

Nesse sentido, é importante ressaltar a aprovação, entre os anos 2001 e 2003, das Diretrizes Curriculares Nacionais (DCNs) dos cursos de graduação na área da saúde - exceto medicina, cujas DCNs foram publicadas em 2014. Tal fato é de extrema relevância, uma vez que no início dos anos 2000, as discussões e publicações sobre qualidade e segurança do paciente na realidade brasileira eram escassas, bem como o interesse e o reconhecimento dos benefícios da formação interprofissional dos profissionais na área da saúde.

Inserir a temática segurança do paciente na formação dos profissionais de saúde, contextualizada para atuação interdisciplinar, pode facilitar a construção da cultura de segurança e, consequentemente, melhorar a qualidade e a segurança na assistência à saúde, além de desenvolver e facilitar o trabalho em equipe dos profissionais nas instituições de saúde, visto que, inseridos no mercado de trabalho, essa será uma das competências requisitadas.

É preciso considerar, também, o aumento do interesse e o acesso às informações relacionadas à segurança do paciente e à qualidade assistencial por parte dos usuários dos sistemas de saúde. Assim, torna-se fundamental a capacitação dos futuros profissionais para atender a tais necessidades.

Portanto é inevitável o questionamento sobre a abordagem e a discussão dessa temática durante a formação dos profissionais de saúde, a fim de que estejam preparados para atuar demonstrando conhecimentos, habilidades e atitudes em relação à segurança do paciente nas práticas assistencial, gerencial e de ensino e pesquisa. 
Isso posto, evidenciam-se como questionamentos neste estudo:

$\checkmark$ Como a segurança do paciente está inserida nos currículos acadêmicos dos alunos de graduação dos cursos de medicina, enfermagem, fisioterapia, nutrição, farmácia, terapia ocupacional e biomedicina?

$\checkmark$ Os alunos têm contato com essa temática durante a sua formação e associam-na à sua prática profissional?

Com o intuito de responder tais inquietações, o presente estudo pretende identificar como a segurança do paciente está incorporada no curso de graduação dos futuros profissionais da saúde e se há alguma interface interprofissional, pois essa temática envolve todos aqueles que atuam direta ou indiretamente na assistência ao paciente nas instituições de saúde.

Frente ao exposto, espera-se que este estudo contribua para 0 reconhecimento da importância da abordagem dessa temática na formação dos profissionais de saúde visando qualificar as práticas assistencial e gerencial nos serviços de saúde. 

OBJETIVOS DO ESTUDO

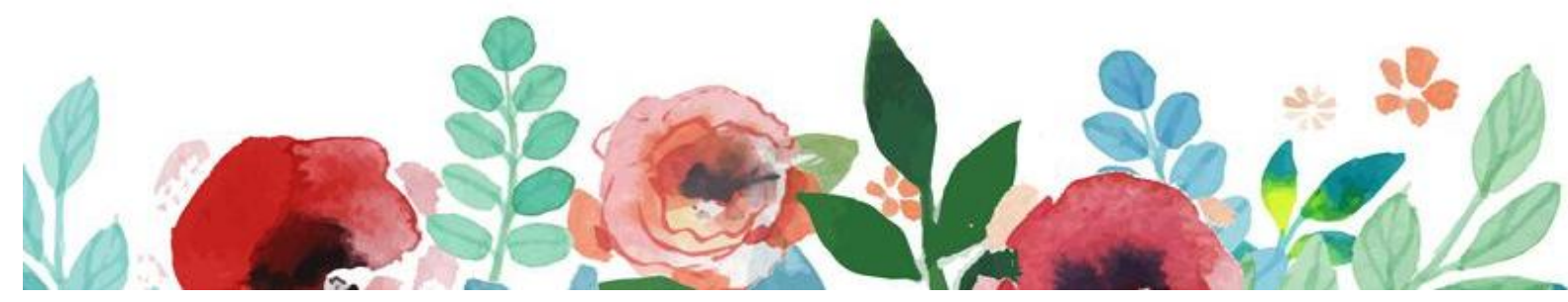



$\checkmark$ Compreender a percepção de discentes de graduação de uma instituição de ensino superior, integrantes dos cursos de enfermagem, medicina, fisioterapia, farmácia, nutrição, terapia ocupacional e biomedicina acerca do ensino da temática segurança do paciente;

$\checkmark$ Propor uma intervenção para a inserção da temática segurança do paciente, de forma interdisciplinar, nos cursos da área da saúde. 

EIXO NORTEADOR

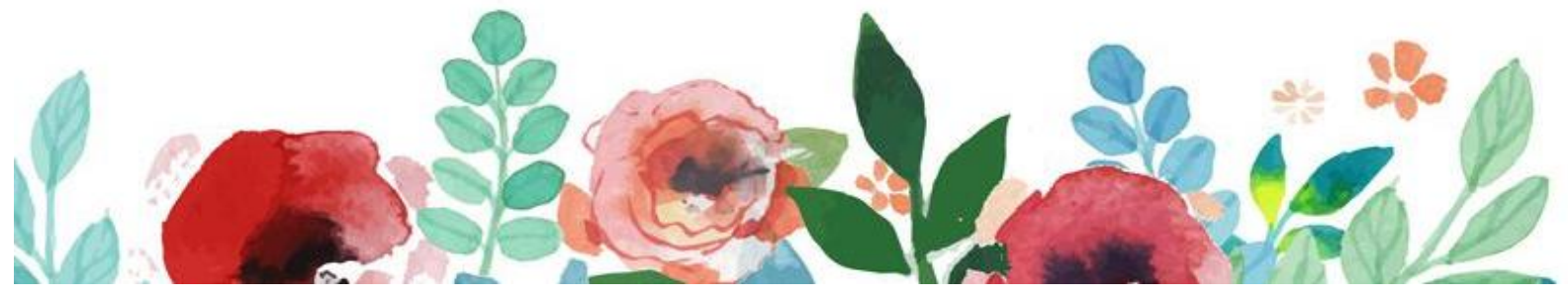



A Figura 1 demonstra os três eixos norteadores nos quais os capítulos desenvolvidos neste estudo foram inseridos:

$\checkmark$ Referenciais teóricos;

$\checkmark$ Pesquisa qualitativa;

$\checkmark$ Viabilidade.

Figura 1 - Esquema demonstrativo da trajetória percorrida no desenvolvimento do estudo. São Paulo, 2018.

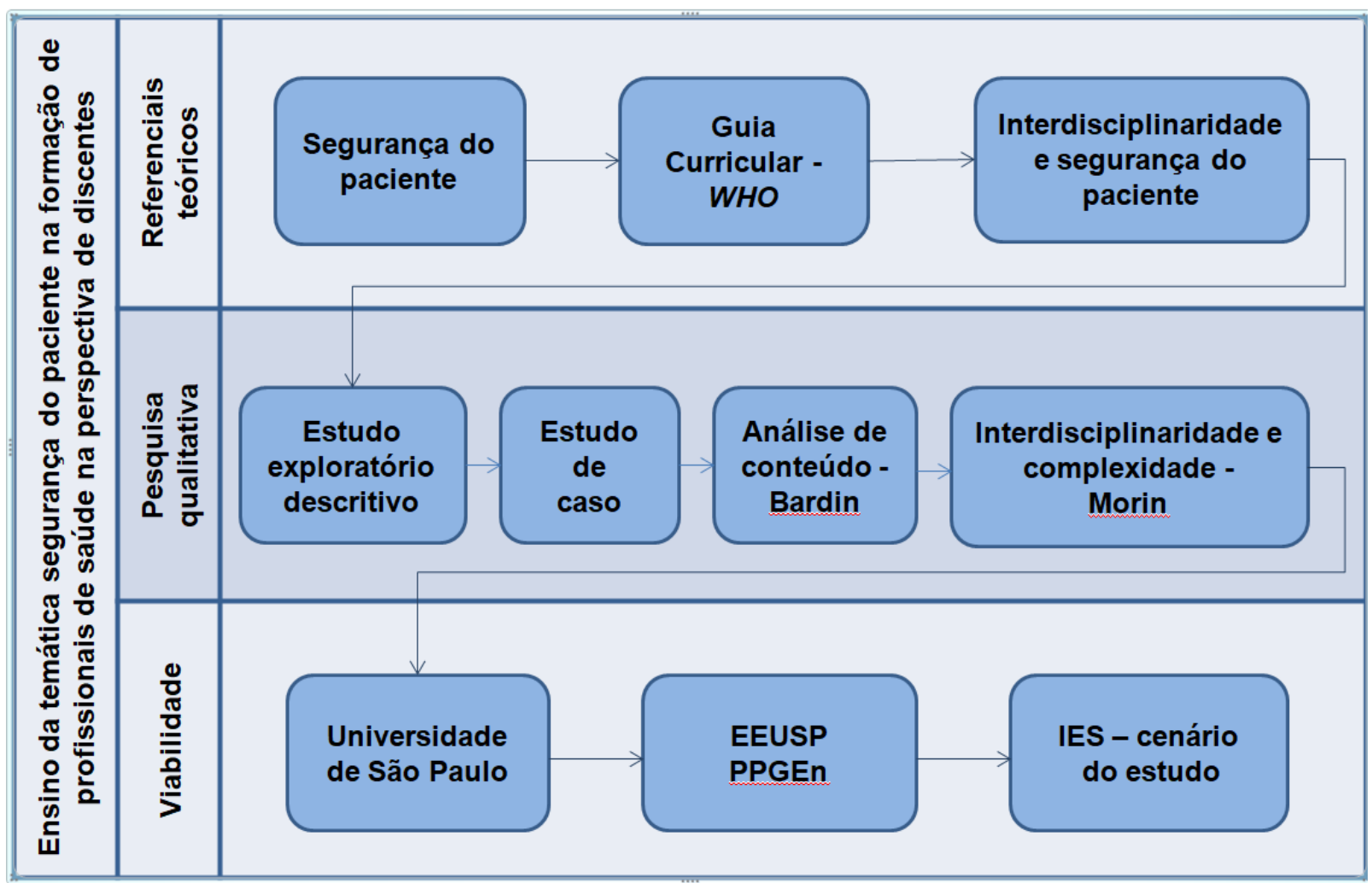



CAPÍTULO 1

A TEMÁTICA SEGURANÇA DO PACIENTE

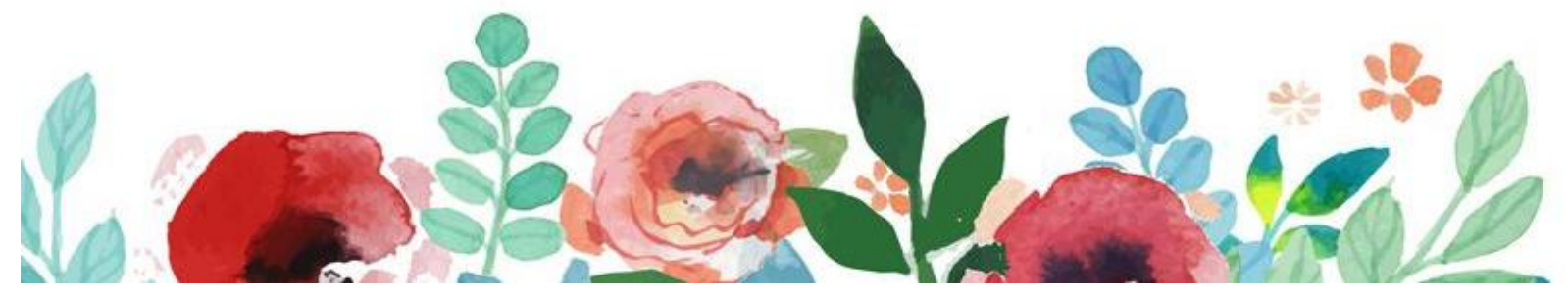



A segurança do paciente tem sido amplamente discutida nos últimos anos pelos profissionais atuantes nas instituições de saúde, principalmente após inúmeras publicações que evidenciaram a incidência de eventos adversos ocorridos nessas instituições e seus impactos, sejam eles na saúde e recuperação do usuário ou nos custos do sistema saúde.

$\mathrm{O}$ Institute of Medicine (IOM) definiu segurança do paciente como o processo de livrar o paciente de lesões acidentais, estabilizando sistemas e processos operacionais, com o objetivo de minimizar a probabilidade de erros e, sobretudo, maximizar a probabilidade de percepção dos erros quando ocorrem (IOM, 2000).

Para Vicent (2009), a expressão segurança do paciente é amplamente utilizada, contudo, raramente definida com clareza. $O$ autor descreve que a segurança do paciente consiste no ato de evitar, prevenir e melhorar os resultados adversos oriundos do processo de assistência à saúde e está inserido nos sistemas e nas pessoas; por isso a temática precisa ser ativamente estimulada, com o objetivo de reduzir os erros e atingir a alta confiabilidade, como componente essencial da qualidade assistencial.

A World Health Organization (WHO), por sua vez, define segurança do paciente como ausência ou redução de danos — associados à assistência desnecessários ou potenciais para o paciente; princípio fundamental do cuidado à saúde que exige uma abordagem abrangente e multiprofissional (WHO, 2009a).

Sousa (2007) refere que a ausência de segurança do paciente pode resultar em falta de confiança nas organizações e nos profissionais de saúde, aumento dos custos sociais e econômicos, além de reduzir a possibilidade de alcançar os resultados esperados, com impacto direto na qualidade da assistência à saúde.

Os erros e danos causados aos pacientes durante a assistência à saúde tiveram maior visibilidade junto aos profissionais de saúde após a publicação do relatório To err is human: building a safer health system pelo IOM, a partir do qual diversos estudos reforçaram a associação do risco com a assistência prestada pelos profissionais de saúde (Silva, 2012). Nesse sentido, torna-se relevante conceituar erro, evento adverso e dano, uma vez que tais termos estão intrinsecamente relacionados à temática segurança do paciente.

Erro é definido como falha na execução de uma ação planejada de acordo com o desejado ou o desenvolvimento incorreto de um plano, seja na fase de organização ou na fase de execução (WHO, 2009a). 
Evento adverso é descrito por Wachter (2013) como lesão ou dano causado em função da assistência à saúde. Podem ser classificados em evitáveis e não evitáveis.

Em contrapartida, a WHO (2009a) define evento adverso como um incidente que resulta em dano ao paciente. Nesse caso, dano caracteriza-se pelo comprometimento da estrutura ou função do corpo, incluindo-se doenças, lesão, sofrimento, incapacidade ou morte.

Os eventos adversos assistenciais apresentam o potencial de causar danos aos pacientes e prejuízos associados aos cuidados à saúde, decorrentes de processos ou estruturas da assistência. Entretanto, cabe ressaltar que o movimento para a segurança do paciente possui como característica a identificação dos erros antes que causem danos aos pacientes, uma vez que considera o erro como uma condição humana e, portanto, deve-se tirar o maior proveito dessa condição, sempre conhecendo, aprendendo e prevenindo erros nos serviços de saúde (Brasil, 2013a).

Assim, é importante conhecer os processos mais críticos e com maior probabilidade de ocorrência de erros dentro do serviço de saúde para que seja possível desenvolver ações eficazes de prevenção.

Considerando a complexidade da assistência à saúde na atualidade, os erros não serão eliminados na sua totalidade, mas seu número e severidade podem ser reduzidos significativamente se a segurança do paciente for considerada uma prioridade tanto pelos profissionais que atuam na assistência como pelos gestores das instituições de saúde (Branco Filho, 2014).

Diante da relevância do assunto, no ano de 2004, foi criada a Aliança Mundial para Segurança do Paciente, uma iniciativa da WHO em parceria com grupos de pacientes e gestores da saúde, com a finalidade de socializar o conhecimento e as soluções encontradas, lançando programas e gerando alertas sobre aspectos sistêmicos e técnicos, bem como consequências do cuidado inseguro à saúde (WHO, 2004; WHO, 2008).

Visando à intensificação dessas ações, em 2007 lançou, através do World Health Organization's Collaborating Center for Patient Safety Solutions, o programa Nine Patient Safety Solution, cujo objetivo foi aperfeiçoar a segurança do paciente com melhorias nos processos assistenciais para a prevenção de erros humanos evitáveis, elencando nove processos considerados críticos em relação à probabilidade de erros, a saber (WHO, 2007): 
$\checkmark$ Gerenciamento de riscos associados a medicamentos com aparência ou nomes similares;

$\checkmark \quad$ Identificação dos pacientes;

$\checkmark$ Comunicação na passagem de plantão e durante a transferência do paciente;

$\checkmark$ Desenvolvimento dos procedimentos corretos no lado correto do corpo humano;

$\checkmark$ Controle das concentrações de soluções eletrolíticas;

$\checkmark$ Manutenção de medicamentos indispensáveis na transferência ou segurança da medicação nas transições de cuidado;

$\checkmark$ Ausência de conexões erradas de cateteres e sondas;

$\checkmark \quad$ Uso único de dispositivos de injeção;

$\checkmark$ Incentivo à higienização das mãos para prevenir infecção associada ao cuidado à saúde.

Em 2009, um grupo de especialistas da Aliança Mundial para Segurança do Paciente publicou a International Classification for Patient Safety, um entendimento internacional de termos e conceitos relevantes no domínio da segurança do paciente com o intuito de facilitar a compreensão e a uniformização dos conceitos, a coleta de dados sistematizados, a agregação e a análise de informação relevante, a comparação entre organizações e o monitoramento de tendências no decorrer do tempo (WHO, 2009a).

Acompanhando as iniciativas mundiais, criou-se no Brasil a Rede Sentinela, composta por instituições que, desde 2002, trabalham com gerenciamento de risco sobre três pilares: busca ativa de eventos adversos, notificação de eventos adversos e uso racional das tecnologias em saúde (Brasil, 2014).

Em 2008, foi instiuída a Rede Brasileira de Enfermagem e Segurança do Paciente (REBRAENSP), com o objetivo de fortalecer a assistência segura e com qualidade, por meio do desenvolvimento de articulação e de cooperação entre instituições de saúde e educação (Cassiani, 2010).

Nos últimos anos, a REBRAENSP estabeleceu seis áreas estratégicas para atuação, conforme descrito no Quadro 1. 
Quadro 1 - Áreas e estratégias de atuação da REBRAENSP.

\begin{tabular}{|c|c|}
\hline Áreas & Estratégia de atuação \\
\hline $\begin{array}{l}\text { Área 1: } \\
\text { Formação em enfermagem e } \\
\text { segurança do paciente }\end{array}$ & $\begin{array}{l}\text { Mobilizar gestores de escolas para a inserção da } \\
\text { temática nos currículos dos cursos de enfermagem dos } \\
\text { níveis médio, graduação e pós-graduação. Contribuir } \\
\text { para a formação profissional que fortaleça o Programa } \\
\text { Nacional de Segurança do Paciente. }\end{array}$ \\
\hline $\begin{array}{l}\text { Área 2: } \\
\text { Extensão às comunidades e } \\
\text { sociedades }\end{array}$ & $\begin{array}{l}\text { Realização de aulas, palestras e eventos que } \\
\text { oportunizem discussões e reflexões acerca da } \\
\text { segurança do paciente. Criação de fóruns permanentes } \\
\text { de discussões multidisciplinares com participação de } \\
\text { membros de organizações comunitárias vinculadas aos } \\
\text { Conselhos Municipais de Saúde. }\end{array}$ \\
\hline $\begin{array}{l}\text { Área 3: } \\
\text { Investigação e disseminação } \\
\text { do conhecimento }\end{array}$ & $\begin{array}{l}\text { Realizar pesquisas relacionadas à temática segurança } \\
\text { do paciente. }\end{array}$ \\
\hline $\begin{array}{l}\text { Área 4: } \\
\text { Políticas públicas }\end{array}$ & Participação na elaboração de políticas públicas. \\
\hline $\begin{array}{l}\text { Área 5: } \\
\text { Serviços de enfermagem e } \\
\text { segurança do paciente }\end{array}$ & $\begin{array}{l}\text { Promover discussões e divulgação dos protocolos sobre } \\
\text { segurança do paciente lançados pelo Ministério da } \\
\text { Saúde e contribuir para a implementação dos Núcleos } \\
\text { de Segurança do Paciente nas instituições de prestação } \\
\text { de assistência em saúde. }\end{array}$ \\
\hline $\begin{array}{l}\text { Área 6: } \\
\text { Expansão e fortalecimento da } \\
\text { Rede }\end{array}$ & $\begin{array}{l}\text { Criar e desenvolver novos Polos/Núcleos da } \\
\text { REBRAENSP. }\end{array}$ \\
\hline
\end{tabular}

Fonte: Caldana, $G$ et. al. Rede brasileira de enfermagem e segurança do paciente: desafios e perspectivas. Texto contexto-enferm. 2015; 24(3): 906-911.

Outra ação relativa à segurança do paciente no cenário nacional diz respeito à publicação da Resolução de Diretoria Colegiada (RDC) 63, de 25 de novembro de 2011, pela Agência Nacional de Vigilância Sanitária (ANVISA), que dispõe sobre os 
requisitos de boas práticas de funcionamento para os serviços de saúde fundamentados na qualificação, na humanização da atenção e gestão e na redução e controle de riscos aos usuários e meio ambiente (Brasil, 2011).

Esse documento direciona as instituições de saúde no estabelecimento de estratégias e ações voltadas para a segurança do paciente: identificação do paciente, higienização das mãos, ações de prevenção e controle de eventos adversos, segurança cirúrgica, administração segura de medicamentos, sangue e hemocomponentes, prevenção de quedas, prevenção de lesões por pressão e orientações para inserir plenamente o paciente/usuário na assistência prestada.

Em abril de 2013, com a finalidade de contribuir para a qualificação do cuidado em saúde, o Ministério da Saúde brasileiro, através da Portaria no 529, instituiu o Programa Nacional de Segurança do Paciente (PNSP) (Brasil, 2013b).

No que diz respeito aos seus objetivos específicos, incluem-se:

$\checkmark$ Promover e apoiar a implementação de iniciativas voltadas à segurança do paciente em diferentes áreas da atenção, organização e gestão de serviços de saúde, por meio da implantação da gestão de risco e de Núcleos de Segurança do Paciente nos estabelecimentos de saúde;

$\checkmark$ Envolver os pacientes e familiares nas ações de segurança do paciente;

$\checkmark$ Ampliar o acesso da sociedade às informações relativas à segurança do paciente;

$\checkmark$ Produzir, sistematizar e difundir os conhecimentos sobre segurança do paciente;

$\checkmark$ Fomentar a inclusão do tema segurança do paciente no ensino técnico e de graduação e pós-graduação na área da saúde.

O PNSP estabeleceu, ainda, a elaboração e a implantação de um conjunto de protocolos básicos, em conformidade com as definições da WHO, destinados à prevenção de eventos adversos, a saber: prática de higiene das mãos em estabelecimentos de saúde; cirurgia segura; segurança na prescrição, uso e administração de medicamentos; identificação de pacientes; comunicação no ambiente dos estabelecimentos de saúde; prevenção de quedas; lesão por pressão; transferência de pacientes entre pontos de cuidado e uso seguro de equipamentos e materiais (Brasil, 2013a). 
Tais protocolos constituem instrumentos para a construção de uma prática assistencial segura e são componentes obrigatórios dos planos locais de segurança do paciente dos estabelecimentos de saúde, de acordo com RDC № 36, de 25 de julho de 2013, publicada pela ANVISA (Brasil, 2013c).

Investir no aperfeiçoamento dos profissionais de saúde, na utilização de boas práticas e no aprimoramento das tecnologias e na melhoria dos ambientes de trabalho constituem questões primordiais para o alcance dos melhores resultados para os usuários dos serviços de saúde, família e comunidade (Brasil, 2013a).

Nessa direção, é imprescindível contar com um quantitativo de profissionais capacitados, motivados e envolvidos no trabalho e que sejam protagonistas no processo em busca da qualidade assistencial e da segurança do paciente (Tronchin, Freitas e Melleiro, 2016).

Quinto Neto (2006) ressalta que os profissionais de saúde se esforçam em proporcionar a melhor assistência possível. Entretanto esse comportamento não impede a ocorrência de eventos adversos, sendo necessária uma abordagem de reconhecimento e de aprendizagem para evitar ou impedir novas ocorrências.

James Reason classificou os erros em dois principais grupos: deslizes e lapsos e enganos, conforme representa a Figura 2 (Reason, 2000).

Figura 2 - Esquema demonstrativo dos principais tipos de erros

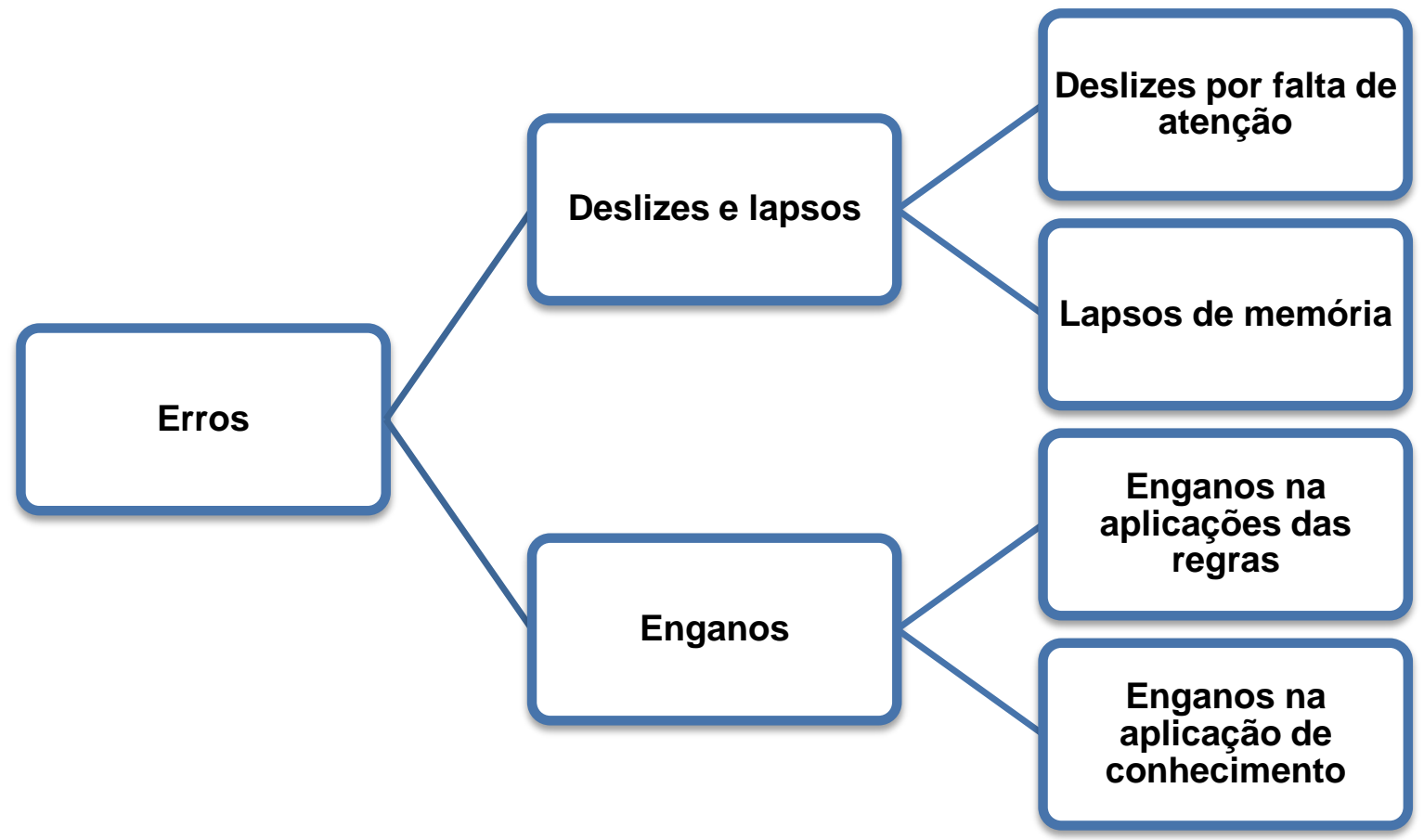

Fonte: Reason J. Humam error: models and management. Brit Med J. 2000; 320:768-70. 
Portanto, de acordo com o autor, deslizes e lapsos são erros de ação e ocorrem quando o indivíduo sabe o que quer fazer, mas a ação não sai conforme a intenção. Os deslizes estão relacionados com ações observáveis e associadas à falta de atenção, enquanto os lapsos são eventos internos associados com falha de memória. Ambos ocorrem durante a realização de uma tarefa rotineira e, geralmente, estão ligados a alguma forma de distração ou provocados por mudanças.

Em relação aos enganos, as ações podem sair da forma como foram planejadas, mas a falha ocorre nos processos mentais envolvidos no julgamento, planejamento, formulação e resolução do problema. Os enganos ocorrem quando o indivíduo não sabe qual regra seguir ou procedimento executar (Reason, 2000).

Nesse sentido, os erros são, por definição, não intencionais. As violações, contudo, são desvios deliberados das regras, recomendações, rotinas e práticas operacionais seguras. Enquanto os erros são cometidos em razão da limitação humana, as violações estão mais relacionadas às atitudes, à motivação, ao ambiente de trabalho e à cultura organizacional (Vicent, 2009).

O erro oriundo da assistência à saúde sempre estará presente; porém pode ser prevenido pelo emprego de sistemas que impossibilitem a sua ocorrência ou que tornem mais difícil para as pessoas fazerem o errado e mais fácil, o certo (IOM, 2000).

O modelo do queijo suíço proposto por Reason (2000) descreve que o erro humano pode ser analisado por meio das abordagens pessoal e sistêmica. $\mathrm{Na}$ pessoal, os erros são provenientes de processos mentais incorretos, como esquecimento, falta de atenção, negligência e imprudência; para controlá-los, é necessário reduzir o indesejável comportamento variável dos humanos com a utilização da censura, ameaça e culpa. A sistêmica, por sua vez, tem como premissa que os humanos cometem falhas, as quais são vistas como consequência e não como causa - o cerne dessa abordagem é que todas as atividades complexas devem possuir barreiras para evitar a ocorrência de eventos adversos e, quando ocorrem, a questão primordial é compreender como e porque falharam.

Assim, de acordo com esse modelo, na ocorrência de um erro, além de identificá-lo, as instituições de saúde devem avaliar, com critério, se as barreiras estão definidas adequadamente a fim de minimizar o dano ao paciente. 
Nesse contexto, a qualidade da assistência à saúde pode ser compreendida como uma busca incessante de identificação de falhas nos procedimentos e protocolos, conduzindo à melhoria dos processos e resultados. Trata-se, ainda, de uma conquista interdisciplinar que exige a participação de todos os profissionais do setor (D'innocenzo, Adami e Cunha, 2006).

O movimento para a segurança do paciente substitui a prática da culpabilidade individual pelos erros na assistência à saúde por uma abordagem que considera avaliar os processos assistenciais em busca das correções imprescindíveis. Esse novo paradigma pressupõe que os profissionais erram, por isso a necessidade da criação de sistemas que antecipem os erros, os previnam ou os interceptem antes que causem dano (Watcher, 2013).

Segundo Leape (2009), os erros são causados por sistemas defeituosos e mal desenhados e para obter-se o alto nível de segurança nas instituições de saúde pelo menos seis mudanças devem ser implementadas: olhar para os erros como falha do sistema; transpor o ambiente punitivo para uma cultura justa; passar do sigilo para a transparência; centrar o cuidado no paciente e não no profissional da saúde; desenvolver modelos para o cuidado e o trabalho em equipe de forma colaborativa, interdependente e interprofissional e, por fim, responsabilização universal e recíproca.

Para a WHO (2009a), a cultura de segurança de uma organização é produto de valores individuais e de grupo, de atitudes, capacidades de percepção e modelos de comportamento que determinam o compromisso com a gestão da saúde e a segurança.

Nas instituições eficazes, portanto, segurança é prioridade máxima que envolve todos os setores e implica no reconhecimento de que suas atividades têm uma natureza de alto risco e são propensas a erros; proporciona um ambiente sem culpa onde os indivíduos são capazes de comunicar erros ou quase eventos sem punição; promove a colaboração entre todos os profissionais para encontrar soluções para as vulnerabilidades e a alocação de recursos, por parte da organização, em assuntos relacionados à segurança (WHO, 2009a).

De acordo com a The Joint Commission (2017), em uma instituição com forte cultura de segurança, os profissionais que ali atuam tratam-se, mutuamente, e aos seus pacientes/usuários com dignidade e respeito. Contudo devem ser considerados alguns elementos na cultura de segurança, entre eles: a cultura justa, a qual trabalha 
com clareza os processos que permeiam erro humano e os comportamentos imprudentes; a cultura da notificação, na qual são relatados os erros e quase erros ou near-misses; e a cultura da aprendizagem, que utiliza as informações do sistema de segurança para implementar melhorias e aprendizados.

Para avançar de forma mais eficiente na abordagem global de sistemas de segurança do paciente, a National Patient Safety Foundation (NPSF) publicou em seu relatório intitulado Free from Harm: Accelerating Patient Safety Improvement Fifteen Years after To Err Is Human, oito recomendações para sustentar as iniciativas de melhoria descritas no Quadro 2.

Quadro 2 - Recomendação para abordagem de sistemas de segurança.

\section{Garantir que os líderes estabeleçam e mantenham uma cultura de segurança:}

Melhorar a segurança exige uma cultura organizacional que habilite e priorize a segurança. A importância da mudança cultural precisa ser levada ao primeiro plano em vez de ser tratada como suporte para várias outras atividades de segurança.

2. Criar supervisão centralizada e coordenada da segurança do paciente: A otimização das iniciativas de segurança do paciente exige envolvimento, coordenação e supervisão de órgãos dirigentes nacionais e outras organizações de segurança.

3. Criar um conjunto comum de métricas de segurança que reflitam resultados significativos: Medição é fundamental para propiciar melhorias. Para promover a segurança, é necessário o estabelecimento de métricas padrão em todo o universo da assistência à saúde e criar formas para identificar e medir os riscos e perigos proativamente.

4. Aumentar o financiamento de pesquisa em segurança do paciente e na ciência da implementação: É essencial promover avanços substanciais na segurança do paciente; tanto a ciência da segurança quanto a da implementação devem ser desenvolvidas para que se entendam completamente os perigos da segurança e as melhores maneiras de preveni-los.

5. Abordar a segurança em todo o universo da assistência à saúde: Os pacientes merecem assistência segura em todos os ambientes. As organizações de assistência à saúde precisam de melhores ferramentas, processos e estruturas para oferecer assistência com segurança e avaliá-la em vários ambientes. 
6. Apoiar a mão de obra de assistência à saúde: Segurança da mão de obra, ânimo e bem-estar são absolutamente necessários para fornecer assistência segura. Enfermeiros, médicos, farmacêuticos, técnicos e outros precisam de apoio para desenvolver seu potencial mais alto como curadores.

\section{Associar-se a pacientes e famílias para promover uma assistência mais segura:} Pacientes e famílias precisam estar ativamente engajados em todos os níveis da assistência à saúde. Na sua essência, o engajamento do paciente tem a ver com o livre fluxo de informações de e para o paciente.

\section{Garantir que a tecnologia seja segura e otimizada para aumentar a segurança do} paciente: Otimizar os benefícios da segurança e minimizar as consequências involuntárias da tecnologia da informação na saúde é fundamental.

Fonte: National Patient Safety Foundation. Free from Harm: Accelerating Patient Safety Improvement Fifteen Years after To Err Is Human, 2015.

A NPSF (2015) descreve, ainda, que proteger os pacientes contra danos durante a assistência envolve mais do que reduzir ou prevenir problemas de segurança durante a hospitalização, pois os pacientes são assistidos em ambientes fora do hospital, como ambulatórios, centros de diagnóstico, unidades assistenciais de longa permanência ou em suas residências, merecendo assistência segura em todos os cenários, assim como quando passam de um ambiente para outro.

Dessa maneira, além dos aspectos relacionados à prevenção dos erros e eventos adversos nos diversos ambientes onde ocorre a assistência à saúde, os profissionais devem possuir conhecimento para diminuir as consequências deletérias após a sua ocorrência e a apropriação desse conhecimento deve-se iniciar durante a sua formação acadêmica.

Por se tratar de um processo em evolução, aumentar a segurança do paciente é considerado um problema complexo, que exige o trabalho de diversas disciplinas para ser solucionado e aponta para a importância de incorporar a segurança do paciente na formação dos profissionais de saúde em vários níveis de treinamento (NPFS, 2015).

Nessa perspectiva, entre as estratégias para a implementação do PNSP, incluiu-se a articulação junto ao Ministério da Educação e ao Conselho Nacional de Educação para a inclusão do tema segurança do paciente nos currículos dos cursos 
de formação em saúde em nível técnico, superior e de pós-graduação (Brasil, 2013b).

Para que a segurança do paciente permeie as instituições de saúde, os novos profissionais devem ter conhecimentos e habilidades para identificar e saber intervir adequadamente quando cometerem ou presenciarem um erro. Assim, os cursos de formação profissional desempenham um papel importante na promoção de habilidades e comportamentos, no que diz respeito ao erro humano e à segurança do paciente, principalmente, ao demonstrarem a relevância dessa temática para a formação dos estudantes e para a assistência prestada ao usuário (Yoshikawa et al., 2013; Bogarin et al., 2014).

De acordo com Leung e Patil (2010), os incidentes ocorridos nos últimos anos tornaram-se importantes para a formação profissional, uma vez que possibilitaram a introdução da segurança do paciente nos currículos, o que significa que os futuros profissionais aprenderão como gerenciar os erros e entenderão os impactos das limitações humanas na prática assistencial. Os mesmos autores descrevem que estudos comparativos em duas universidades norte-americanas, com estudantes antes e depois da introdução formal da temática segurança do paciente no currículo, têm demonstrado um incremento no conhecimento, habilidades e comportamentos dos futuros profissionais.

Pearson e Steven (2009) descreveram que há pouca evidência da efetiva incorporação da segurança do paciente nos currículos dos cursos da área da saúde, embora os currículos formais sejam gradualmente incentivados a acrescentar essa temática. Além disso, não está claro até que ponto o ensino sobre segurança do paciente é conduzido pelo currículo informal ou oculto, nem as estratégias educacionais são mais eficazes na criação de mudanças.

No relatório Teaching Physicians to Provide Safe Patient Care, Leape (2010) recomenda que o ensino da segurança do paciente nos cursos de medicina inicie no primeiro dia da graduação, seja estendido ao longo do curso e incorporado em todas as atividades de ensino. Salienta, ainda, que a educação para a segurança do paciente é muito mais do que conhecer os conceitos, pois requer atenção especial à aquisição de habilidades, atitudes e comportamentos desejados para que se tornem inerentes ao modo de atuação profissional. Apesar de ser direcionada à graduação de medicina, tais recomendações deveriam ser adotadas em todos os cursos da área da saúde. 
Nessa mesma publicação, o autor listou doze recomendações para melhorar a educação em segurança do paciente, dentre elas destaca-se a recomendação na qual as escolas médicas devem conceituar e tratar a segurança do paciente como uma ciência que engloba o conhecimento da causalidade e mitigação de erros, conceitos de fatores humanos, melhoria da segurança, teoria e análise de sistemas, desenho e redesenho de sistemas, de trabalho em equipe e revelação do erro (Leape, 2010).

A WHO (2010) recomenda que os alunos aprendam inclusive sobre como os sistemas e a comunicação impactam na qualidade e segurança dos cuidados, além de desenvolver estratégias para prevenir o erro e as complicações, bem como reagir e atuar de forma apropriada, avaliando os resultados para melhorar o desempenho progressivamente.

O ensino sobre segurança do paciente e melhoria da qualidade para os alunos dos cursos da área da saúde é relativamente um novo conceito, mas tem sido reconhecido como vital para o futuro do cuidado em saúde (Miller, Winterton e Hoffman, 2014).

Assim, há de se pensar na transformação da cultura de formação dos profissionais de saúde, visando o comprometimento genuíno de todos os envolvidos com as questões relacionadas à qualidade da assistência e da segurança do paciente, uma vez que esses mesmos aspectos repercutirão nas instituições de saúde onde tais profissionais atuarão.

Conforme vimos, qualidade dos serviços e segurança dos pacientes têm sido amplamente discutidas na literatura nacional e internacional, assumindo papel relevante no desenvolvimento de esforços para tornar a assistência ao paciente mais segura em serviços de saúde (Brasil, 2013a).

Entretanto, nas IES, ainda são incipientes os esforços para inserir, efetivamente, essa temática na formação dos futuros profissionais de saúde. Tal percepção ocorre tanto de forma empírica, devido à falta de discussão sobre a temática entre os docentes das IES, como na escassez de estudos que evidenciam a efetiva inserção do assunto nas matrizes curriculares dos cursos de graduação na área da saúde.

Essa realidade pode levar a uma desarticulação nos processos de trabalho dos profissionais de saúde, os quais são exigidos pelo mercado de trabalho para a prestação de uma assistência de excelência. 


\subsection{A FORMAÇÃO DOS PROFISSIONAIS DE SAÚDE NO QUE TANGE A SEGURANÇA DO PACIENTE: A ESTRATÉGIA PROPOSTA PELA WHO}

Frente ao exposto no tópico anterior e acreditando na importância da inserção da segurança do paciente nas matrizes curriculares dos cursos de graduação na área da saúde, é relevante discorrer sobre a proposta da WHO ao sugerir um conteúdo mínimo a ser abordado na formação dos profissionais de saúde sobre essa temática, reforçando a compreensão sobre a relevância de minimizar os erros assistenciais e maximizar a cultura do cuidado seguro.

Sob essa ótica, a WHO publicou em 2011 o Guia Curricular Multiprofissional de Segurança do Paciente (Patient Safety Curriculum Guide: Multi-professional Edition) baseado no Guia Curricular para Escolas de Medicina (Curriculum Guide for Medical Schools), publicado em 2009 (WHO, 2011).

O Guia Curricular é pertinente no contexto das reformas educacionais globais e do crescente reconhecimento da necessidade de introduzir a segurança dos pacientes nos currículos dos profissionais de saúde de forma integrada e compartilhada, reforçando a capacidade dos alunos para trabalhar em conjunto de forma eficaz. Além disso, fornece orientação sobre uma variedade de métodos de ensino e atividades pedagógicas para garantir que os alunos compreendam que a segurança do paciente é uma ciência prática, ensinando-os a agir de forma baseada em evidências para reduzir o risco de erros e ajudar os professores a incorporar tópicos de segurança dos pacientes em todas as áreas da prática clínica (Leotsakos et al., 2014).

Capacitar o corpo docente na temática segurança do paciente é essencial para incorporá-la ao currículo. Em geral, buscam atualização profissional e são especialistas nas disciplinas que ministram, porém, o conhecimento em segurança do paciente requer aprendizagem adicional que extrapola as especialidades e as estratégias tradicionais (WHO,2011).

A principal finalidade desse projeto foi contribuir para o ensino de segurança do paciente na área de saúde, uma vez que existe a necessidade de desenvolver e integrar a segurança do paciente aos currículos das diferentes profissões. Sendo assim, os objetivos do Guia Curricular encontram-se descritos no Quadro 3. 
Quadro 3 - Objetivos propostos pelo Guia Curricular da WHO.

Preparar os alunos da área de saúde para a prática segura no local de trabalho.

Informar as instituições de ensino da área de saúde sobre os tópicos-chave em segurança do paciente.

Intensificar a presença da segurança do paciente como tema a ser abordado ao longo de toda a formação profissional.

Estabelecer um currículo abrangente para auxiliar o ensino e integrar o aprendizado de segurança do paciente.

Capacitar continuamente os professores em segurança do paciente.

Promover um ambiente seguro e favorável para ensinar segurança do paciente.

Introduzir ou reforçar o ensino de segurança do paciente em todos os contextos de formação em assistência à saúde no mundo.

Aumentar a visibilidade internacional do ensino e da aprendizagem de segurança do paciente.

Fomentar a colaboração internacional entre pesquisas sobre educação em segurança do paciente no ensino superior.

Fonte: Word Health Organization. Patient safety curriculum guide: multi-professional edition, 2011

A referida publicação está dividida em duas partes, sendo a primeira direcionada aos docentes de cursos da área da saúde, com o objetivo de desenvolver ou aprimorar os conhecimentos e habilidades necessárias para implementar a segurança do paciente nas IES. Fornece, ainda, informações de como selecionar e ensinar os tópicos de segurança do paciente no currículo e integrar a temática na formação dos estudantes, bem como exemplos de avaliação de aprendizagem.

O restante do Guia Curricular é dirigido aos docentes e alunos e é composto pelo detalhamento de 11 tópicos básicos que devem ser abordados sobre segurança do paciente nos cursos de graduação na área da saúde, conforme descrito a seguir:

\section{O que é segurança do paciente?}

Aborda princípios e definições requeridos aos profissionais da saúde. 
2. Por que a aplicação de fatores humanos é importante para a segurança do paciente?

Propõe o desafio para os profissionais e estudantes da área da saúde em compreender a inter-relação entre as pessoas e o ambiente de trabalho, a engenharia, o sistema e os processos relacionados ao fator humano e seu impacto na segurança do paciente.

3. Compreender os sistemas e o efeito da complexidade no cuidado ao paciente.

Os estudantes podem entender a complexidade do sistema de saúde que integra departamentos, unidades, serviços, além da prática assistencial e suas relações nas organizações.

4. Ser um participante de uma equipe eficaz.

Conhecer os benefícios de atuar em equipes multidisciplinares para a melhoria da assistência e para a redução de erros, bem como a importância da comunicação entre os membros da equipe, incluindo o paciente.

\section{Aprender com os erros para evitar danos.}

Possibilita aos profissionais de saúde e aos estudantes entender como e por que os sistemas e os processos de trabalho contribuem para a ocorrência do erro, aprender a evitá-los e compreender que, na assistência à saúde, os erros também são a base para a realização de melhorias e implementação de sistemas de comunicação eficazes.

\section{Entender e gerenciar o risco clínico.}

A gestão do risco clínico envolve todos os níveis da organização e está centrada na melhoria da qualidade e na segurança dos serviços de saúde, identificando as circunstâncias que colocam os pacientes em risco e agindo para evitar ou controlar esses riscos.

7. Utilizar métodos de melhoria da qualidade para aprimorar o cuidado. Inserir nas matrizes curriculares os principais conceitos da melhoria da qualidade e suas ferramentas, incorporando-os na prática clínica através da identificação e da avaliação de processos mensuráveis da assistência à saúde. 


\section{Interação com pacientes e cuidadores.}

A importância da equipe assistencial inclui o paciente e/ou seu cuidador como elemento fundamental na garantia de cuidados de saúde seguros.

\section{Prevenção e controle de infecção.}

Tem por objetivo apresentar as principais causas e as infecções associadas aos procedimentos e à assistência à saúde; capacitar os estudantes para identificar as ações que colocam os pacientes em risco de infecção e prepará-los para tomarem a medidas adequadas no intuito de prevenir sua transmissão.

\section{Segurança do paciente e procedimentos invasivos.}

Uma das principais causas de erros envolvendo pacientes, locais e procedimentos é a incapacidade dos profissionais de saúde se comunicarem de forma eficaz em procedimentos pré-operatórios. Este tópico aborda os benefícios de usar listas de verificação ou protocolos, bem como o conhecimento de princípios subjacentes que apoiam a uniformidade na abordagem para tratar e cuidar de pacientes.

\section{Melhorar a segurança do processo de medicação.}

Aborda a vulnerabilidade dos pacientes aos erros em qualquer uma das etapas envolvidas na prescrição, dispensação e administração de medicamentos.

A elaboração desses 11 tópicos sobre segurança do paciente na formação dos profissionais da área da saúde, proposto pelo Guia Curricular da WHO, baseouse na Australian Patient Safety Education Framework (APSEF), publicada em 2005 pela Australian Council on Safety and Quality in Health Care (ACSQHC), composta por 22 tópicos de aprendizagem distribuídos em sete categorias, que descrevem o conhecimento, as habilidades e os comportamentos necessários no processo de aprendizado sobre segurança do paciente (Walton et al., 2006; WHO, 2011).

O Guia Curricular da WHO incluiu um tópico relacionado ao controle de infecção que não foi abordado pela APSEF (WHO, 2011).

Outra publicação que contribuiu na elaboração do Guia Curricular pela WHO foi The Safety Competencies, publicado em 2009 pelo Canadian Patient Safety Institute, que abordou de forma interdisciplinar o conhecimento, as habilidades e as 
atitudes requeridas pelos profissionais de saúde agrupadas em seis domínios (Frank, Brien, 2008; WHO, 2011).

Faz-se necessário salientar que o ensino de segurança do paciente apresenta alguns fatores dificultadores: o primeiro deles diz respeito à falta de reconhecimento, por parte dos docentes, de que ensinar e aprender sobre segurança do paciente deve ser essencial nos currículos de graduação dos cursos da área da sáude. $\mathrm{O}$ segundo refere-se aos professores estarem ou não receptivos ao conhecimento vindo de outras áreas, tais como análise de sistemas e gerenciamento e melhoria da qualidade. O último fator está relacionado à atitude tradicional e hierarquizada entre professor e aluno, na qual um especialista dissemina informações para os alunos ao invés da construção coletiva do conhecimento (Walton et al., 2009; WHO, 2011).

A supervisão e a orientação dos professores e responsáveis pelo acompanhamento dos alunos são particularmente relevantes para a educação em segurança do paciente, uma vez que os estudantes naturalmente tentam copiar e modelar seu comportamento com o de seus instrutores. Ou seja, a conduta desses profissionais terá uma grande influência sobre a forma como os alunos irão, eventualmente, assistir o paciente ao finalizarem sua formação (WHO, 2011).

Essa publicação da WHO, portanto, procura preencher a lacuna na educação sobre segurança do paciente com a sugestão de um currículo desenvolvido para que tanto os professores quanto os estudantes da área da saúde sejam preparados para integrar a prática clínica em diferentes áreas de atuação com o conhecimento, as habilidades e as atitudes inerentes à segurança do paciente.

A construção do conhecimento sobre segurança do paciente deve ocorrer ao longo de toda a formação dos estudantes na área da saúde, a fim de que desenvolvam habilidades e comportamentos tão logo iniciem as atividades em um serviço de saúde. Dessa maneira, além dos conhecimentos adquiridos, os alunos podem ser agentes transformadores e modelos para os profissionais que já atuam no sistema de saúde (WHO, 2011).

Assim, os alunos precisam saber sobre qualidade e segurança da assistência à saúde e como os problemas de comunicação podem levar a eventos adversos. Precisam aprender, também, a gerir esses desafios e a desenvolver estratégias para prevenir e responder a erros e complicações, bem como a forma de avaliar os resultados para melhorar o desempenho a longo prazo (WHO, 2011). 
A WHO descreve, ainda, que os estudantes necessitam compreender quão eficazes são os cuidados de saúde quando há trabalho interdisciplinar e a importância da inclusão dos pacientes e suas famílias como parte da equipe: o trabalho em equipe pode reduzir erros e melhorar o atendimento aos pacientes, especialmente os que apresentam doenças crônicas (WHO, 2011).

Nessa direção, os profissionais de saúde devem ser formados para a assistência centrada no paciente como membros de uma equipe interdisciplinar, com ênfase na prática baseada em evidências, em abordagens de melhoria da qualidade e da segurança e utilizando a tecnologia da informação para melhorar a comunicação, mitigar erros e dar suporte às decisões (WHO, 2011).

A WHO (2011) destaca que a publicação do Guia Curricular fornece a base para a difusão do conhecimento sobre segurança do paciente em um contexto internacional, possibilitando aos estudantes da área da saúde não apenas atuarem em seu país de formação, mas também em outros países. É importante considerar que a internacionalização do ensino sobre segurança do paciente facilita o uso de tecnologias de e-learning que permitem uma interconectividade global e o compartilhamento de informações, recursos e atividades de aprendizagem.

O estudo realizado por Farley et al. (2015) avaliou doze IES que desenvolveram o ensino sobre segurança do paciente baseado no Guia Curricular da WHO em vários continentes. Os resultados demonstraram maior facilidade dos professores na abordagem da temática e aumento nas percepções e atitudes dos alunos em relação à importância da segurança do paciente e sua capacidade de influenciá-la.

No cenário nacional, destaca-se o estudo de Bohomol e Cunha (2015), que utilizaram o Guia Curricular da WHO para avaliar o projeto pedagógico do curso de graduação em medicina de uma universidade federal. Constataram que são ministrados diversos temas relacionados à segurança do paciente, contudo o ensino é fragmentado, com maior valorização dos conteúdos que desenvolvem as habilidades clínicas, e não apresentam interdisciplinaridade.

Os resultados de outro estudo brasileiro que também utilizou o Guia Curricular da WHO para avaliar os projetos pedagógicos dos cursos de graduação em enfermagem, farmácia, fisioterapia e medicina de uma universidade federal demonstraram que alguns assuntos relacionados à segurança do paciente estavam presentes no currículo formal, mas percebeu-se a valorização dos aspectos 
específicos da formação pretendida em cada um dos cursos sem interdisciplinaridade entre eles nessa temática específica (Bohomol, Freitas, Cunha, 2016).

A pesquisa conduzida por Melleiro et.al (2017) realizada em nove IES públicas e privadas de São Paulo utilizou como referencial teórico o Guia Curricular da WHO, analisou os planos de ensino das matrizes curriculares dos cursos de graduação em enfermagem e obstetrícia e concluiu que a temática segurança do paciente esteve presente nos conteúdos programáticos analisados, embora de maneira desarticulada e heterogênea, tornando-se necessário buscar práticas mais significativas que repercutam ao longo da formação do estudante e que futuramente subsidiem sua atuação profissional.

Diante desse contexto e considerando a proposta do Guia Curricular publicado pela WHO como um ponto fundamental para a inserção da temática segurança do paciente nas matrizes curriculares dos cursos de graduação da área da saúde, este estudo terá por finalidade precípua analisar a percepção dos discentes acerca dos 11 tópicos preconizados na referida publicação durante sua formação em uma IES. 

CAPÍTULO 2

ABORDAGEM INTERDISCIPLINAR E SUA INTERFACE COM A SEGURANÇA DO PACIENTE

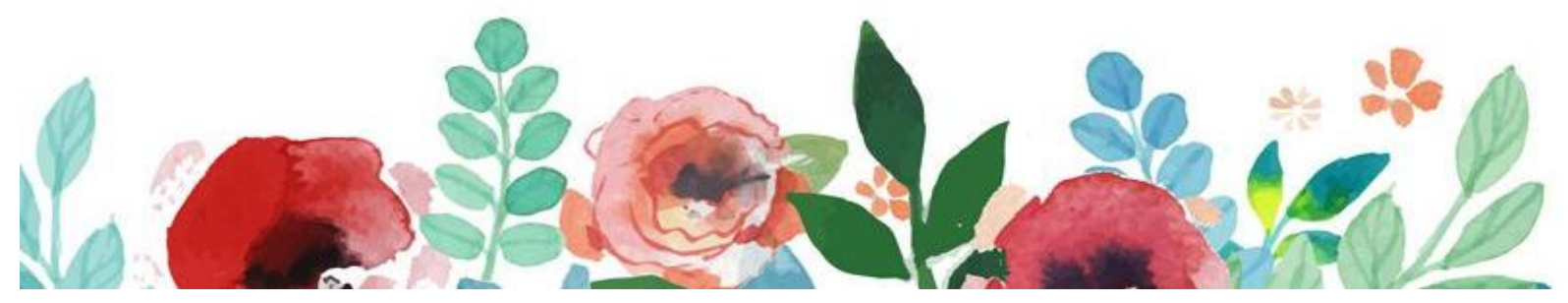



O processo de desenvolvimento e a construção de novos saberes ocorrem continuamente para os profissionais da área da saúde mediante o avanço científico e o incremento de novas tecnologias. No que tange à segurança do paciente, cuja temática passou a ser discutida com maior enfoque a partir do ano 2000 e repercute em todos aqueles que atuam direta ou indiretamente na assistência ao paciente, a aquisição de novos conhecimentos por meio da abordagem interdisciplinar e da prática colaborativa podem contribuir para melhores resultados assistenciais.

A interdisciplinaridade tem sido objeto de discussão quando se aborda as ciências da saúde e a formação dos profissionais nessa área de atuação como forma de compreender a complexidade dos fenômenos e diminuir os efeitos provocados pela fragmentação do saber (Saupe et al., 2005; Gattás, 2005).

Minayo (1994) descreveu ser impossível conceituar consensualmente a interdisciplinaridade; Japiassu (1976), um dos pioneiros desse estudo no Brasil, levantou a possibilidade do referido neologismo tomar sentidos amplos e diversificados. Segundo ele, antes de compreender 0 sentido do termo interdisciplinaridade, é necessário saber o que vem a ser a disciplinaridade, descrita como uma progressiva exploração científica especializada numa certa área ou domínio homogêneo de estudo, com seus objetos materiais e formais, métodos e sistemas, bem como conceitos e teorias.

A definição de disciplina é complementada por Morin (2011a) como uma categoria que organiza o conhecimento científico, instituindo a divisão e a especialização de domínios das ciências que tendem à autonomia por meio da linguagem, das técnicas e pelas teorias que lhe são próprias. Destaca, ainda, que a disciplinaridade pode acarretar a hiperespecialização e a percepção do objeto da disciplina como autossuficiente, o que pode dificultar ou negligenciar as ligações com objetos estudados por outras disciplinas, assim como as relações com o universo do qual ele faz parte.

A partir da definição de disciplinaridade, faz-se necessário distinguir os conceitos de multidisciplinaridade, interdisciplinaridade e transdisciplinaridade. Nesse sentido, de acordo com Morin (2011a), interdisciplinaridade significa troca e cooperação entre disciplinas de forma orgânica. Em contrapartida, o conceito de multidisciplinaridade constitui-se em uma associação de disciplinas em razão de um projeto ou de um objeto que Ihes sejam comuns. Enquanto que transdisciplinaridade caracteriza-se por esquemas cognitivos que atravessam as disciplinas; são redes 
complexas de inter e multidisciplinaridade.

Não se pode demolir o que as disciplinas criaram. É preciso que uma disciplina seja, ao mesmo tempo, aberta e fechada, pois deve-se pensar no que the é necessário e no que lhe está além, uma vez que é impossível conhecer as partes sem conhecer o todo, tanto quanto conhecer o todo sem conhecer as partes (Morin, 2011a).

Ainda de acordo com Morin (2011b), a fragmentação do conhecimento leva a uma visão reducionista do saber, impossibilita a compreensão dos fenômenos e da realidade complexa. A educação deve estar aberta às novas formas de organização da aprendizagem e necessita atrelar-se aos princípios da complexidade. Não olhar o todo induz à continuidade dessa fragmentação (Morin, 2011c).

Perceber como as partes e os fenômenos apresentam conexões faz com que o indivíduo entenda que cada ação das partes tem seus desdobramentos e repercussões sobre o todo. Portanto, para êxito do todo, é necessário que todas as partes sejam percebidas numa ideia de unidade. Essa visão pode mudar a forma do profissional refletir, agir e se relacionar no seu ambiente e com os demais integrantes da equipe (Mendonça, 2016).

Minayo (1991) descreveu que a interdisciplinaridade pode ser considerada um ponto de equilíbrio entre a análise fragmentada e a síntese simplificadora, entre a especialização e o saber geral. No que corresponde aos conceitos fundamentais, sua construção inicia-se com o aprofundamento das disciplinas para em seguida passar para a síntese, que aproxima os fragmentos convergentes, os quais levam à complementaridade dos conceitos e à construção de um saber que supera o das disciplinas originais.

A interdisciplinaridade é uma exigência do mundo contemporâneo, só possível devido à sua capacidade de adaptar-se à realidade contextual, assumir nuances, singularidades e diversidades, possibilitando 0 enfrentamento de problemáticas complexas (Fazenda, 2013).

Nas ciências da saúde, a complexidade das questões suscita a contribuição de um olhar plural de especialistas que precisam ser, ao mesmo tempo, sujeitos da totalidade e partes de um todo, viabilizando o trabalho conjunto que integra os elementos das disciplinas na busca de soluções compartilhadas para os problemas das pessoas e das instituições (Carvalho, 2007; Saupe, 2005). 
Para Headrick et al. (2012), a formação em qualidade e em segurança do paciente é a mola propulsora para a educação interdisciplinar e tem levado ao desenvolvimento de programas de educação inovadores que contribuem para alinhar a educação dos profissionais de saúde com as necessidades contemporâneas e uma mudança no sistema de saúde. Ressaltam, ainda, que a formação dos profissionais de saúde deve prepará-los para trabalharem deliberadamente de forma interdisciplinar em direção a um sistema de saúde mais seguro.

A abordagem da temática segurança do paciente deve perpassar todo 0 currículo e enfocar especificidades de riscos e medidas preventivas de dano nos diversos cenários de assistência à saúde, atentando-se para que os aspectos relacionados à segurança do paciente não sejam minimizados dentre outros tão importantes no ensino em saúde. Assim, tanto o aluno quanto o professor devem vivenciar práticas significativas no processo ensino-aprendizagem, de forma que possam repercutir na atuação segura ao longo da formação e que se sustentem também no desempenho profissional (Urbanetto, Gerhardt, 2013).

Partindo do princípio da interdisciplinaridade, destacam-se a educação e a prática interprofissional como temas emergentes no campo da saúde, tendo em vista a tendência dos profissionais de cada área em trabalhar de forma isolada e independente, dada a sua formação ter ocorrido desse modo e circunscrita à sua própria área de atuação (Peduzzi et al., 2013).

A educação interdisciplinar na formação profissional ocorre quando estudantes de duas ou mais profissões aprendem sobre os outros, com os outros e entre si para possibilitar a efetiva colaboração e melhorar os resultados na saúde. Os profissionais da área da saúde atuais e futuros são desafiados a enfrentar problemas cada vez mais complexos e que necessitam de uma força de trabalho preparada para a prática colaborativa por meio da educação interdisciplinar (WHO, 2010).

Entretanto é necessário mais do que reunir alunos de cursos diferentes em atividades conjuntas; é preciso desenvolver os recursos cognitivos, afetivos e psicomotores desses alunos para a identificação e o atendimento das necessidades de saúde nas situações apresentadas, respeitando o grau de autonomia e o domínio de cada profissão. Assim sendo, a educação interdisciplinar na área da saúde possibilita integrar o cuidado especializado com o cuidado holístico, opondo-se a 
fragmentação da assistência especializada e oportunizando a interface entre o saber técnico e a prática clínica com os aspectos relacionados à qualidade e segurança dessa prática. (Aguilar-da-Silva, Scapin e Batista, 2011).

Segundo a WHO (2010), a educação interdisciplinar e a prática colaborativa podem ser conceitos difíceis de implementar. Alguns profissionais de saúde acreditam estar atuando de forma colaborativa, simplesmente porque trabalham junto a outros profissionais de saúde, mas eles podem estar apenas trabalhando em um grupo no qual cada indivíduo concordou em usar suas próprias habilidades para alcançar um objetivo comum. Colaboração, portanto, não se refere somente a acordo e comunicação, mas sim à criação de sinergia.

A vivência de aprendizagens interativas na educação interdisciplinar promove o desenvolvimento de competência para a prática colaborativa. Para que isso ocorra, entretanto, faz-se necessário investir, primeiramente, na criação de uma cultura acadêmica que insira a prática colaborativa e compartilhada também entre os professores (Batista, Batista, 2016).

Existem evidências suficientes para indicar que a educação interdisciplinar proporciona a efetiva prática colaborativa a qual, por sua vez, otimiza os serviços de saúde, fortalece os sistemas de saúde e incita melhorias de resultados na saúde e na segurança dos pacientes, uma vez que pode reduzir as complicações de pacientes, o número e o tempo de internação, a tensão e o conflito entre os profissionais de saúde, a rotatividade de profissionais, as taxas de erros médicos e mortalidade (WHO,2010).

Através da educação interdisciplinar, é possível desenvolver os futuros profissionais de saúde para o trabalho em equipe, de forma que a competência e a autonomia de cada um sejam reconhecidas e respeitadas, assim como o senso de responsabilidade, a comunicação entre os profissionais, o foco e o envolvimento do paciente culminem na a assistência à saúde de forma integrada, com maior qualidade, segurança e ética.

A WHO (2010) reforça que, ao proporcionar a educação interprofissional em saúde, os profissionais desenvolvem comportamentos que facilitam a prática colaborativa nas instituições a que se vinculam gerando maior benefício à população atendida. Tais comportamentos podem ser classificados em seis domínios de aprendizado descritos no Quadro 4. 
Quadro 4 - Domínios do aprendizado e comportamentos desenvolvidos pela educação interdisciplinar em saúde.

\begin{tabular}{|c|c|}
\hline Domínio do aprendizado & Comportamento desenvolvido \\
\hline \multirow[b]{2}{*}{ Trabalho em equipe } & Capacidade de atuar como líder e membro da equipe. \\
\hline & $\begin{array}{l}\text { Conhecimento dos obstáculos para o trabalho em } \\
\text { equipe. }\end{array}$ \\
\hline $\begin{array}{l}\text { Funções e } \\
\text { responsabilidades }\end{array}$ & $\begin{array}{l}\text { Compreensão das próprias funções, aptidões e } \\
\text { responsabilidades bem como dos demais } \\
\text { profissionais de saúde. }\end{array}$ \\
\hline \multirow{2}{*}{ Comunicação } & Expressão apropriada de opiniões aos colegas. \\
\hline & Saber ouvir os membros da equipe. \\
\hline \multirow{2}{*}{ Aprendizado e reflexão crítica } & $\begin{array}{l}\text { Reflexão crítica sobre a própria relação em uma } \\
\text { equipe. }\end{array}$ \\
\hline & $\begin{array}{l}\text { Transferência do aprendizado interprofissional para o } \\
\text { ambiente de trabalho. }\end{array}$ \\
\hline \multirow{2}{*}{$\begin{array}{l}\text { Relação com o paciente e } \\
\text { identificação de suas } \\
\text { necessidades }\end{array}$} & $\begin{array}{l}\text { Trabalho colaborativo com foco na melhor assistência } \\
\text { ao paciente. }\end{array}$ \\
\hline & $\begin{array}{l}\text { Envolvimento com pacientes, famílias, cuidadores e } \\
\text { comunidades como parceiros no gerenciamento do } \\
\text { cuidado. }\end{array}$ \\
\hline \multirow{2}{*}{ Prática ética } & $\begin{array}{l}\text { Compreensão das visões estereotipadas próprias e } \\
\text { de terceiros sobre outros profissionais de saúde. }\end{array}$ \\
\hline & $\begin{array}{l}\text { Reconhecimento de que os pontos de vista de cada } \\
\text { profissional de saúde são igualmente válidos e } \\
\text { importantes. }\end{array}$ \\
\hline
\end{tabular}

Fonte: Word Health Organization. Framework for action on interprofessional education \& collaborative practice, 2010.

O relatório Health professions education: a bridge to quality emitido pelo IOM (2003) ressaltou a necessidade da educação interdisciplinar e da prática colaborativa dos profissionais de saúde centrada em cinco pilares: 
$\checkmark$ Atenção centrada no paciente, respeito e cuidado com as diferenças, valores, preferências e necessidades expressas pelos pacientes;

$\checkmark$ Trabalhar em equipes interdisciplinares para coordenar, colaborar, comunicar e integrar o cuidado para garantir que o atendimento seja contínuo e confiável;

$\checkmark$ Empregar a prática baseada em evidências e integrar os melhores resultados das pesquisas clínicas com os valores dos pacientes;

$\checkmark$ Aplicar as ferramentas da qualidade para identificar os erros e os riscos nos cuidados e medir continuamente a qualidade dos cuidados, além de compreender e aplicar princípios básicos da segurança do paciente;

$\checkmark$ Utilizar a informática para comunicar, gerenciar o conhecimento, mitigar erros e apoiar a tomada de decisões.

Considerando a abordagem interdisciplinar, a segurança do paciente deve ser inserida transversalmente nos currículos dos cursos da área da saúde das IES, de maneira que todas as disciplinas discutam de forma contextualizada essa temática, assim como criem oportunidades de discussão e atuação conjunta dos diferentes profissionais ao longo da formação (Wegner et al., 2016).

Não obstante, o preparo dos professores deve ser contemplado pois, embora sejam profissionais especializados e experientes na sua área de atuação, devem ser sensibilizados em relação à segurança do paciente, uma vez que atuam como agentes deflagradores de processos de melhoria no sistema de saúde e na formação da identidade profissional dos alunos (Bohomol, Freitas e Cunha, 2016).

A revisão sistemática realizada por Kiersma, Plake e Darbishire (2011), apontou algumas razões que dificultavam o engajamento dos alunos de cursos na área da saúde com questões de qualidade e segurança do paciente nos Estados Unidos até recentemente, entre elas: os professores não se sentem confiantes em ensinar esse conteúdo, as questões de qualidade e segurança não foram identificadas como prioridades educacionais e os cuidados relacionados à qualidade e melhoria dos sistemas não eram tão relevantes quanto à prática clínica.

Os esforços para melhorar a segurança do paciente devem incorporar o desenvolvimento de novas competências dos profissionais de saúde desde a sua formação, com um currículo que incentive a abordagem integrada dessa temática, 
até a prática baseada em evidências, de tal forma que os profissionais de saúde possam estar confortáveis para identificar e aprender com os erros oriundos, principalmente, dos sistemas e processos de trabalho e não dos indivíduos (VanGeest e Cummins, 2003).

A redução de eventos adversos e a melhoria da qualidade dos cuidados em saúde podem ser alcançadas com especialistas formados para trabalhar com foco na segurança do paciente, em colaboração com os demais profissionais. Assim, é possível reduzir seus riscos e dos pacientes, gerenciar os incidentes de forma pró ativa e maximizar as oportunidades de aprender com os eventos adversos e near miss (ACSQHC, 2005).

Diante dessas considerações, acreditamos ser fundamental a inclusão da temática segurança do paciente de forma interdisciplinar nas IES, almejando que a vivência acadêmica entre alunos de diversos cursos da área da saúde em atividades integradas promova o reconhecimento da atuação, responsabilidade e autonomia de cada integrante da equipe de saúde, bem como a importância do trabalho colaborativo para a melhoria da qualidade e segurança na assistência prestada. 

CAPÍTULO 3

PERCURSO METODOLÓGICO

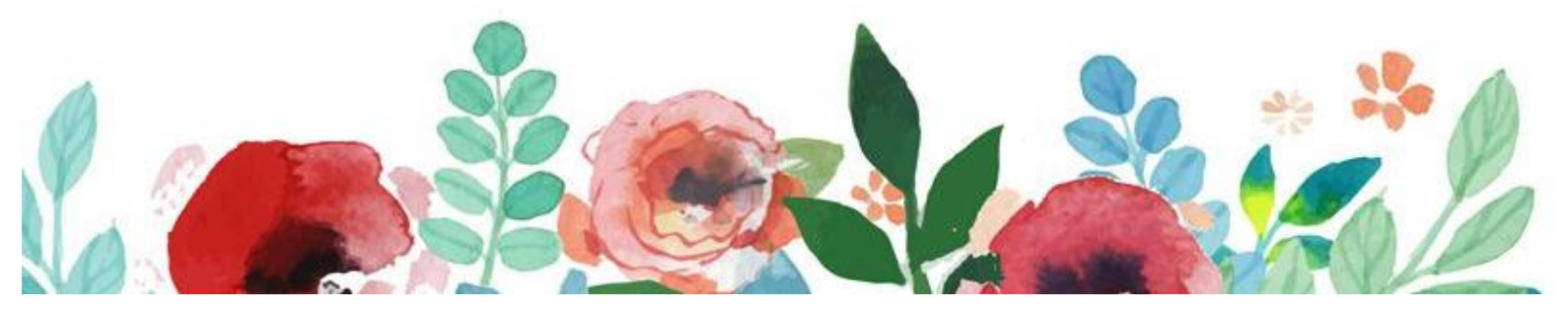





\subsection{DELINEAMENTO DA INVESTIGAÇÃO}

Tendo em vista compreender a percepção dos discentes de graduação de cursos da área da saúde acerca do ensino da temática segurança do paciente, consideramos adequado adotar, neste estudo, a pesquisa qualitativa, com delineamento exploratório-descritivo, na modalidade estudo de caso.

A pesquisa não prescinde da criatividade, entretanto se realiza fundamentalmente por meio do trabalho baseado em conceitos, proposições, hipóteses, métodos e técnicas. Inicia-se com a pergunta da pesquisa e termina com a resposta ou o produto que, por sua vez, poderá dar origem a novas indagações (Minayo, 2016).

$\mathrm{Na}$ pesquisa qualitativa, procura-se a compreensão da lógica interna de grupos, instituições e atores quanto aos valores e representações sobre a sua história e temas específico, com ênfase em seus processos e representações atribuídas pelas pessoas ao fenômeno em questão (Minayo, 2016).

Nessa abordagem, a preocupação com o universo dos significados, os motivos, as aspirações, crenças, valores, atitudes e hábitos dos indivíduos permitem-nos entender o que pensam sobre suas experiências em determinadas situações. Portanto um instrumento a mais para explorar a discussão de temas com profundidade (Minayo, 2014).

A pesquisa qualitativa busca, portanto, a compreensão dos significados e das características situacionais apresentadas pelos participantes, cujas convicções subjetivas passam a ter hegemonia explicativa sobre o conhecimento teórico do investigador (Bertonha, 2007).

Os estudos descritivos têm como proposta a descrição e a elucidação dos fenômenos em seu contexto. Os exploratórios, por sua vez, investigam a natureza complexa, os fatores a ela relacionados e desvendam as várias maneiras pelas quais o fenômeno se manifesta sem a expectativa de uma resposta definitiva (Gil, 2009; Polit, Beck, 2011).

De acordo com Stake (2005), o estudo de caso não tem por finalidade representar o mundo, mas sim o caso específico, que pode ser classificado em três tipos: o intrínseco (estuda a singularidade do caso em si como objeto de interesse do investigador), o instrumental (examina um caso em particular a partir de uma teoria refinada, na qual o caso configura-se como facilitador para a compreensão de 
algo maior) e o coletivo (estudo instrumental extensivo a vários casos articulados para a investigação e compreensão de um fenômeno).

Segundo Gil (2009), o estudo de caso mostra-se muito útil para proporcionar uma visão mais clara acerca de fenômenos pouco conhecidos, além de fornecer explicações de fatos e fenômenos tanto para propósitos exploratórios quanto descritivos e explicativos.

Como modalidade de pesquisa, o estudo de caso é uma metodologia que propõe a investigação de um caso específico, contextualizado em tempo e espaço, para que se realize uma busca circunstanciada de informações com foco na análise do caso e na representação dele dentro do todo (Ventura, 2007).

Lüdke (2013), no entanto, destaca que o estudo de caso visa à descoberta do fenômeno no contexto em que ele se situa, com o objetivo de tentar retratar a realidade de forma completa e profunda, revelando a multiplicidade de dimensões presentes dentro do todo.

O estudo de caso utiliza estratégias para mapear, descrever e analisar o contexto, as relações e percepções a respeito do fenômeno e possibilita, ainda, gerar conhecimento sobre as características significativas e fatores que interferem em determinados processos (Minayo, 2014).

Yin (2015) esclarece que o estudo de caso investiga um fenômeno contemporâneo, o caso, em profundidade e em seu contexto de mundo real, de forma que seja possível entendê-lo e relacioná-lo às condições contextuais.

Nessa direção, de acordo com o objetivo desta pesquisa, consideramos apropriada a adoção da modalidade de estudo de caso, uma vez que se dispõe a compreender a percepção de discentes de graduação acerca do ensino da temática segurança do paciente.

\subsection{CONTEXTO DA INVESTIGAÇÃO}

Este estudo foi desenvolvido em uma IES privada fundada em 1975 no município de São Paulo e que iniciou suas atividades com cursos técnicos na área da saúde. A implantação da graduação deu-se em 1977 com o curso de nutrição; mais tarde, em 1981, com a fusão de outra instituição existente desde 1959, foi incorporada a graduação em enfermagem. Em 1997, recebeu do Ministério da 
Educação o credenciamento de Centro Universitário e introduziu progressivamente os cursos de fisioterapia, farmácia, terapia ocupacional, tecnologia em radiologia, ciência da computação e administração de empresas. Em 2007, foram implantadas as graduações de medicina e psicologia e, em 2008, biomedicina e tecnologia em gastronomia.

A referida IES possui hospitais escola e uma clínica escola multidisciplinar que, além de atenderem a comunidade, oferecem ao discente a possibilidade de colocar em prática a teoria aprendida em sala de aula em ensinos clínicos e estágios supervisionados.

Atualmente dois campi sediam o ensino de graduação, pós-graduação Lato Sensu, com cursos de especialização em diversas áreas do conhecimento, e Stricto Sensu, que oferece mestrado, doutorado e pós-doutorado em bioética, mestrado profissional em enfermagem no processo de cuidar em saúde e mestrado profissional em nutrição.

Para a realização desta investigação foram escolhidos os sete cursos de graduação da área da saúde oferecidos na referida IES, a saber: enfermagem, biomedicina, fisioterapia, farmácia, terapia ocupacional, nutrição e medicina.

O curso de graduação em enfermagem tem como missão formar hoje o enfermeiro do amanhã: diagnosticador, crítico, empreendedor e promotor de saúde, através da formação e do aperfeiçoamento de profissionais generalistas com visão humanística, éticos e competentes para atuar de modo relevante na assistência e na gestão dos serviços de enfermagem, em benefício da sociedade.

A missão do curso de graduação em biomedicina é gerar profissionais com formação generalista, humanista, crítica e reflexiva para atuarem em todos os níveis de atenção à saúde, com base no rigor científico e intelectual e capacitados ao exercício de atividades referentes às análises clínicas laboratoriais, pesquisas básica e aplicada, diagnóstico por imagem, bioengenharia e análises de bioderivados, pautados em princípios éticos e na compreensão da realidade social, cultural e econômica do seu meio, dirigindo sua atuação para a transformação do produto profissional em benefício da sociedade.

No que tange ao curso de graduação em fisioterapia, o objetivo é formar o fisioterapeuta com conhecimento amplo e generalista, comprometido eticamente com a profissão e com a sociedade, humano, crítico, criterioso e capaz de atuar em 
todos os níveis de atenção à saúde, pautado de rigor científico, intelectual e ético.

Referente ao curso de graduação em farmácia, sua missão é contribuir para a melhoria da qualidade de vida da população, formando profissionais éticos e competentes para atuar em atenção à saúde.

O curso de terapia ocupacional tem como pressuposto contribuir para a melhoria da qualidade de vida da população brasileira, formando profissionais éticos, críticos e competentes para atuar de modo relevante no exercício da profissão em benefício da sociedade.

A missão do curso de graduação em nutrição é formar profissionais capacitados a atuar com percepção crítica da realidade social, desenvolvendo atividades técnicas fundamentadas em princípios científicos e éticos, promovendo, preservando e recuperando a saúde individual e coletiva, contribuindo com a melhoria da qualidade de vida, através da alimentação equilibrada.

E, finalmente, o curso de graduação em medicina objetiva formar o médico generalista, estimulando, além da aquisição dos conhecimentos técnicos desejáveis para a atuação na área médica, o desenvolvimento de profissionais humanizados, éticos e críticos que possam atuar conjuntamente com todos os profissionais da área da saúde, visando o cuidado integral.

Quadro 5 - Aspectos gerais dos cursos de graduação participantes deste estudo. São Paulo, 2018.

\begin{tabular}{|c|c|c|c|c|}
\hline $\begin{array}{c}\text { Curso de } \\
\text { graduação }\end{array}$ & $\begin{array}{c}\text { Início das } \\
\text { atividades }\end{array}$ & $\begin{array}{c}\text { Número de } \\
\text { semestres }\end{array}$ & $\begin{array}{c}\text { Número de } \\
\text { vagas } \\
\text { oferecidas por } \\
\text { ano }\end{array}$ & $\begin{array}{c}\text { Número de } \\
\text { alunos } \\
\text { matriculados } \\
\text { em 2017 }\end{array}$ \\
\hline Biomedicina & 2008 & 08 & 200 & 515 \\
\hline Enfermagem & 1981 & 10 & 200 & 600 \\
\hline Farmácia & 1998 & 10 & 100 & 138 \\
\hline Fisioterapia & 1997 & 10 & 200 & 391 \\
\hline Medicina & 2007 & 12 & 100 & 612 \\
\hline Nutrição & 1977 & 08 & 220 & 1342 \\
\hline $\begin{array}{c}\text { Terapia } \\
\text { ocupacional }\end{array}$ & 1998 & 08 & 0 & 43 \\
\hline
\end{tabular}


O Quadro 5 demonstra os aspectos gerais das atividades dos cursos de graduação participantes deste estudo no que concerne ao início da oferta do curso pela IES, após aprovação do Ministério da Educação do Brasil, o número de semestres que o compõem, a quantidade de vagas oferecidas anualmente, considerando os dois campi, e o número total de alunos matriculados em cada curso.

Observamos que Terapia Ocupacional não oferece vagas para novos ingressantes e deverá encerrar suas atividades, após 20 anos de implantação, em virtude da baixa demanda de interessados.

\subsection{ASPECTOS ÉTICOS}

Esta pesquisa foi submetida à Comissão de Ética da Escola de Enfermagem da Universidade de São Paulo - EEUSP, através da Plataforma Brasil, sob o parecer no 1.400 .152 (ANEXO 1), respeitando-se os trâmites legais estabelecidos por esse órgão e ao Comitê de Ética e Pesquisa da IES sob o parecer № 1.427.184* Após aprovações das instituições, a pesquisadora solicitou aos coordenadores dos cursos participantes a indicação e o contato de alunos dos últimos semestres para convidá-los a participar da pesquisa.

O convite foi feito pela pesquisadora de duas maneiras: via e-mail, observando a indicação dos coordenadores, e presencialmente, na sala de aula. Em ambas as abordagens, foram apresentados os objetivos da pesquisa.

Mediante aceitação espontânea dos participantes, as entrevistas foram agendadas em data e horário consensuados entre as partes e realizadas em local que garantiu a privacidade para a sua realização.

Atendendo às normas presentes na Resolução 466, de dezembro de 2012, que versa sobre as Diretrizes e Normas regulamentadoras de pesquisa em seres humanos (Brasil, 2012), a pesquisadora esclareceu os participantes sobre os objetivos da pesquisa, a garantia do sigilo das informações, a voluntariedade, a plena liberdade de desistência da participação, o registro em áudio e o compromisso da utilização dos dados apenas para fins acadêmicos. Antes do início da entrevista, todos assinaram o Termo de Consentimento Livre e Esclarecido (APÊNDICE A).

"O documento de aprovação do Comitê de Ética e Pesquisa da IES não foi anexado devido ao compromisso de sigilo com a instituição pesquisada, contudo encontra-se em poder da pesquisadora, podendo ser solicitado quando necessário. 


\subsection{PARTICIPANTES DO ESTUDO}

Participaram desta pesquisa 21 discentes regularmente matriculados nos últimos semestres dos cursos de enfermagem, medicina, fisioterapia, farmácia, nutrição, terapia ocupacional e biomedicina.

A escolha em questão ocorreu devido ao entendimento da pesquisadora de que tais cursos proporcionam o contato do estudante com os pacientes durante 0 período de estágio em instituições de saúde que desenvolvem suas atividades pautadas na qualidade e segurança da assistência prestada nas diferentes áreas de atuação.

Segundo Minayo (2014), no processo de definição dos participantes da pesquisa qualitativa, deve-se privilegiar os sujeitos sociais que detêm os atributos que o investigador pretende conhecer, uma vez que a preocupação está voltada ao aprofundamento e à abrangência da percepção desse grupo. Isso inclui definir claramente o grupo social mais relevante, cujo número de participantes é determinado de acordo com a compreensão do fenômeno estudado.

Na pesquisa qualitativa, os participantes tendem a ser escolhidos de maneira deliberada, pois é necessário dispor daqueles que gerem dados relevantes e fartos, considerando o objeto de estudo (Yin, 2016).

Assim, o número de discentes de cada curso foi definido no momento em que as falas convergiram e aproximaram-se por semelhança à temática estudada e quando foram atingidos dados suficientes que respondiam à indagação da pesquisa.

\subsection{COLETA DE DADOS}

A coleta de dados aconteceu entre os meses de agosto e outubro de 2016, por meio de entrevista semiestruturada (APÊNDICE B), que utilizou as seguintes questões norteadoras elaboradas pela própria pesquisadora:

$\checkmark$ Como você percebe a temática segurança do paciente no ensino de graduação?

$\checkmark$ Descreva-me em qual momento do curso de graduação você teve contato com a temática segurança do paciente. 
$\checkmark$ Frente aos 11 tópicos sugeridos pela OMS e apresentados a você nesta entrevista, como você acredita que isso poderia ser inserido na sua formação?

A entrevista é uma técnica para coleta de dados cujo objetivo é compreender o significado que os entrevistados atribuem a questões e situações apontadas pelo pesquisador, por meio de informações e opiniões que decorrem de uma conversação livre (Martins, 2008).

De acordo com Silverman (2009), a entrevista qualitativa busca a interação com o participante, a fim de compreender sua experiência, ideias e opiniões a respeito do fenômeno. Dessa forma, é realizada em caráter colaborativo, pois participante e pesquisador compartilham uma conversa que produz dados através do relato do participante. As entrevistas gravadas são consideradas um registro público; podem ser reproduzidas, melhorando as transcrições e preservando o sentido da conversa.

Para Minayo (2016), a entrevista é a estratégia mais utilizada no trabalho de campo de uma pesquisa qualitativa e tem como objetivo construir informações pertinentes para o objeto da pesquisa. Quando realizada de forma semiestruturada, possibilita ao entrevistado discorrer sobre o tema em questão.

As entrevistas deste estudo duraram em média 30 minutos e foram inteiramente gravadas em áudio. Fluíram próximas a uma conversa, com respostas espontâneas em forma de narrativa. Quando necessário, a pesquisadora solicitou esclarecimentos e detalhes em relação à abordagem da temática segurança do paciente durante a formação acadêmica.

\subsubsection{Material ilustrativo utilizado nas entrevistas}

No momento da entrevista foi apresentado aos participantes um encarte elaborado pela pesquisadora, cujo conteúdo versava sobre os 11 tópicos relacionados no Guia Curricular de Segurança do Paciente: edição Multiprofissional (WHO, 2011). Esse material, acrescido de gravuras e textos referentes aos supracitados tópicos preconizados pela WHO no que diz respeito à aprendizagem do tema segurança do paciente (APÊNDICE C), serviu de apoio à condução das entrevistas.

O emprego das ilustrações objetivou provocar a memória dos discentes em 
relação a situações e discussões ocorridas durante as aulas teóricas ou práticas, de forma que, por meio da semelhança das situações representadas, as entrevistas trouxessem maior detalhamento,

A apropriação dos efeitos de sentido de elementos significantes das imagens em processos de comunicação é trabalhada no campo da semiótica - ciência geral de todos os sistemas de signos, através dos quais se estabelece a comunicação entre os homens (Ramalho e Oliveira, Gaspar, Ramalho e Oliveira, 2009).

Charles Pierce, considerado um dos maiores estudiosos da semiótica, definiu signo como aquilo que, sob certo aspecto ou modo, representa algo para alguém que cria em sua mente um signo equivalente que representa ou faz referência a uma ideia ou um conteúdo familiar (Pierce, 2003).

Dentre as características dos signos estudados pela semiótica, destacam-se os ícones, cujo objetivo é sugerir algo por representar alguma semelhança com o objeto ou situação reproduzida e podem ser exemplificados por fotografias, desenhos, ilustrações ou representações figuradas (Pierce, 2003; Pepulin, Fialho e Souza, 2013).

Ao observar um signo, inicia-se um processo mental de identificação que se baseia na classificação e na inferência das representações desse signo e sua interpretação, considerando o conhecimento individual prévio. Assim, de acordo com a semiótica de Peirce, os seres humanos reconhecem e interpretam o mundo ao seu redor a partir das inferências dos signos que compõem o pensamento e que se organizam em linguagens (Pierce, 2003; Nicolau, et al., 2010).

O signo é construído para representar algo e produzir um estímulo cognitivo imediato no indivíduo que, a partir de suas experiências e conhecimentos anteriores, elabora uma interpretação significativa e traduzida para aquela realidade vivenciada (Pierce, 2003; Plaza, 2010).

Por conseguinte, são considerados uma forma de linguagem e, portanto, uma ferramenta de comunicação visual, uma vez que se constituem em uma mensagem para o outro que os interpretará de acordo com seus conhecimentos, vivências e contexto inserido (Joly, 2012).

Nesse âmbito, a elaboração do APÊNDICE C objetivou representar situações relevantes para o ensino da segurança do paciente aos futuros profissionais da saúde, de tal forma que os signos contribuíssem para o reconhecimento e a 
interpretação do assunto principal abordado em cada um dos tópicos descritos no Guia Curricular, e auxiliar o processo de comunicação com os entrevistados.

Podemos afirmar que o uso do material ilustrativo nas entrevistas atendeu ao objetivo almejado; ficou evidente a contribuição das gravuras e dos textos para despertar a memória dos discentes no que concerne às situações vivenciadas ou discutidas durante a sua formação acadêmica e relacioná-las aos tópicos preconizados no Guia Curricular.

\subsection{ORGANIZAÇÃO E ANÁLISE DOS DADOS}

Com o intuito de transformar em textos as 21 entrevistas gravadas em áudio, foram utilizadas as etapas preconizadas por Meihy e Holanda (2017), descritas como transcrição, textualização e transcriação, detalhadas na Figura 3.

Figura 3 - Etapas para a transposição da linguagem oral para a escrita realizadas em cada entrevista.

Etapa 1 - transcrição: a entrevista foi integralmente transformada da linguagem oral para a escrita. As perguntas e as respostas, bem como as repetições e vícios de linguagem, foram mantidos em estado bruto.

Etapa 2 - textualização: as questões norteadoras foram eliminadas e incorporadas às respostas; os erros gramaticais e osvícios de linguagem foram retirados para compor a narrativa.

Etapa 3 - transcriação: os parágrafos da narrativa foram ordenados e recriados, de forma que o texto estático fosse transformado em uma leitura dinâmica, capaz de retratar o contexto, o sentido e a intenção da entrevista.

Fonte: Meihy JCSS, Holanda F. História oral: como fazer, como pensar. $2^{\underline{a}}$ ed. São Paulo: Contexto, 2017.

Após cada entrevista ter sido trabalhada exaustivamente em todas as etapas descritas acima até estabelecer o texto final transcriado, as narrativas foram 
encaminhadas por e-mail aos respectivos participantes para leitura, conferência e validação do conteúdo utilizado na análise deste estudo. Meihy e Holanda (2017) reforçam que essa etapa é importante e tem como objetivo que o participante se reconheça no texto apresentado.

Cabe salientar que todos retornaram o contato da pesquisadora e não apresentaram questionamentos, dúvidas ou sugestões em relação ao texto final, validando-os integralmente, dando 0 aval para que os dados produzissem conhecimento a respeito do fenômeno estudado.

Após a validação das narrativas, as entrevistas foram identificadas com letras e números, sendo a letra correspondente à inicial do curso do participante e a numeração sequencial, de acordo com a realização da entrevista, em relação a cada um dos cursos.

Para o estudo das narrativas, decidimos pelo método de análise de conteúdo descrito por Bardin (2011): organizado em torno de três etapas, recomenda conhecer o que está por trás das palavras sobre as quais se debruça:

$\checkmark$ Pré-análise

Trata-se da fase de organização propriamente dita, na qual deve-se retomar a hipótese e os objetivos iniciais da pesquisa, além de realizar a leitura flutuante que implica em conhecer e criar familiaridade com o material a ser estudado, de forma que se constitua o corpus da análise de conteúdo. Para tanto, é necessário obedecer às regras de exaustividade e não seletividade, representatividade, homogeneidade, pertinência e exclusividade. Nessa etapa, determinam-se a unidade de registro, a unidade de contexto, a forma de categorização, a modalidade de codificação e os modelos teóricos gerais que orientação a análise do conteúdo;

\section{$\checkmark$ Exploração do material}

Nessa fase aprofunda-se a análise das narrativas para que seja possível definir as categorias ao classificar os elementos constitutivos de um conjunto e realizar o agrupamento por analogia e por unidade de significação temática, de acordo com os núcleos de sentido identificados; 
$\checkmark \quad$ Tratamento dos resultados, inferência e interpretação Implica em tratar os dados brutos para que se tornem significativos e válidos, propor inferências e interpretações, além da análise comparativa, ressaltando os aspectos considerados semelhantes e os concebidos como diferentes.

As narrativas dos 21 participantes, cujo texto final considerou as etapas definidas por Meihy e Holanda (2017), estão apresentadas a seguir, no Capítulo 4.

As categorias definidas após a identificação dos núcleos de sentido que emergiram das narrativas, a partir o emprego das etapas da análise de conteúdo de Bardin (2011), estão descritas no Capítulo 5. 

CAPÍTULO 4

NARRATIVAS

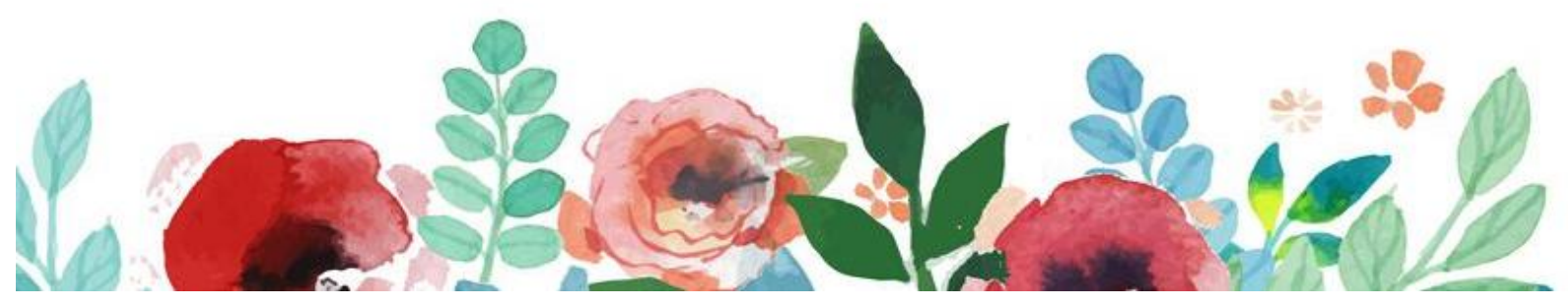



As narrativas apresentadas a seguir foram produzidas a partir das 21 entrevistas individuais realizadas pela pesquisadora com cada participante, cujas etapas para o preparo do texto final foram detalhadas no capítulo anterior.

Constituem material valioso, pois fazem referência à experiência pessoal sobre a situação ou contexto narrado e tendem a ser detalhadas, com enfoque nos acontecimentos e ações, expressando, assim, a verdade sob um ponto de vista e de uma situação específica no tempo e no espaço (Jovchelovitch, Bauer, 2002).

Para Gibbs (2009), representam uma das formas fundamentais com que as pessoas organizam a compreensão do mundo, contextualizam, dão sentido às suas experiências passadas e as compartilham por meio do relato da sua vivência.

Riessman (2005), no entanto, destaca que não falam por si só e requerem interpretação quando utilizadas em pesquisas sociais. Dessa maneira, as falas oriundas das experiências pessoais dos participantes devem ser selecionadas, organizadas, conectadas e avaliadas em relação aos seus significados, considerando os objetivos da pesquisa.

Flick (2009) descreve que as narrativas produzidas por meio da entrevista semiestruturada podem ser usadas para a obtenção de uma versão mais abrangente e contextualizada das opiniões e experiências. Geralmente, incluem situações colocadas em uma sequência de acontecimentos, dos quais nem sempre há uma interpretação temporal, construindo-se a experiência como um processo.

Outro ponto relevante da escolha da narrativa, diz respeito ao uso do material de apoio composto por ilustrações durante as entrevistas. De acordo com Bank (2009), o significado do contexto no qual uma imagem é apresentada funde-se ao significado da imagem propriamente dita e pode evocar comentários, memória e discussão, desencadeando um fluxo de detalhes no decorrer da entrevista.

Dessa forma, permitem ir além da transmissão de informações ou conteúdo, fazendo com que a experiência seja revelada, considerando aspectos fundamentais da compreensão do sujeito entrevistado individualmente e do contexto em que ele está inserido (Muylaert et al., 2014), o que nos levou a decidir pela adoção desse tipo de texto para o estudo.

A narrativa permeia nossas vidas, em diferentes instâncias, em diferentes lugares, compondo a espessura do viver (Castellanos, 2014), e revela-se um instrumento importante nas pesquisas qualitativas, ao produzir dados capazes de gerar conhecimento científico compromissado com a apreensão fidedigna e real dos 
dados, ao combinar histórias de vida com o contexto no qual o participante está inserido (Muylaert et al, 2014).

Nesse sentido, as narrativas a seguir foram compostas por interpretações e representações da temática segurança do paciente na formação dos discentes participantes, considerando o ponto de vista e a experiência diante das questões norteadoras e das ilustrações apresentadas no momento da entrevista que suscitaram elementos para posterior análise do fenômeno. 


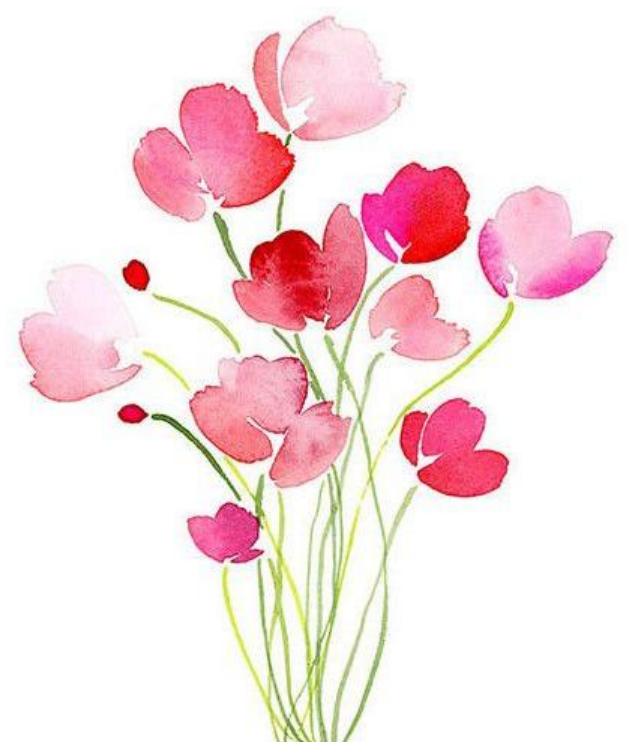

E1 - Estudante do 9 semestre do curso de graduação em enfermagem, 25 anos Data: 24/08/2016, às $13 \mathrm{~h} 30$ 

Na minha vivência da graduação, em todos os momentos foi abordada a segurança do paciente. Como a minha grade foi dividida em saúde do idoso, criança, adolescente e adulto, cada professor tinha seu modo de falar sobre essa temática, relacionando-a com cada faixa etária que estávamos aprendendo. De forma geral, também discutimos a segurança do paciente quando estudávamos as regras de como montar um hospital, o que observar e cobrar da nossa equipe em relação à segurança do paciente. Então, isso desde o princípio sempre foi abordado.

Eu acho que é muito importante, porque os profissionais sempre pensam nos seus direitos e o que importa para eles, mas precisamos pensar no outro também, porque se a gente não pensar no paciente, eles sabem quais são seus direitos e vão nos cobrar, então precisamos ter esse conhecimento sobre segurança do paciente.

A abordagem nas disciplinas sempre foi bem específica: a maioria dos professores trabalhava a questão dos cinco certos, que viraram sete certos, depois nove e agora 11. Eles sempre abordaram e renovaram isso porque o conhecimento é atualizado no dia a dia da enfermagem. Dessa forma, todas as disciplinas abordaram a segurança do paciente do seu jeito.

Em relação ao primeiro item do manual da OMS [Organização Mundial da Saúde], foi ensinado desde o começo o que é segurança, o porquê e quais são as consequências quando não seguimos os passos corretos para a segurança do paciente.

O segundo item, que fala sobre a aplicação dos fatores humanos, também foi discutido, além da questão da anotação de enfermagem e da evolução, que tratam da segurança do paciente, pois o registro garante que ele recebeu as medicações, a forma que foram realizados $o$ cuidado e o transporte de um paciente de um setor para o outro. A passagem de plantão e um prontuário completo são importantes para o profissional do setor que vai receber o paciente saber exatamente o que aconteceu com ele. A questão da tecnologia e seu impacto foi citada apenas na praticidade do trabalho. Eu, como técnica de enfermagem, expliquei para os alunos da minha sala como é no meu trabalho e porque lá a tecnologia impacta bastante na segurança do paciente; contei a minha experiência com o uso da tecnologia: medicação informatizada com código de barras, a checagem no sistema e a obrigatoriedade em mostrar ao paciente o que consta no equipamento utilizado no momento da administração do medicamento. Essa é a minha realidade, mas não é algo que a gente vê na graduação, porque a maioria dos hospitais, mesmo aqueles nos quais fizemos estágio, não fornece isso.

A complexidade do sistema foi um assunto muito abordado devido à dificuldade que temos em fazer o sistema funcionar como deveria, principalmente pelas matérias que falavam de saúde pública e o quanto isso interfere não só na segurança como no tratamento do paciente. $A$ dificuldade que o paciente tem de entender o tratamento, muitas vezes o faz tomar 0 medicamento da forma errada porque ele vai à UBS [Unidade Básica de Saúde] e lá falam uma coisa, no AMA [Assistência Médica Ambulatorial], por exemplo, falam outra. Então fica até uma questão de insegurança do paciente e esse assunto foi muito explorado.

O trabalho em equipe também foi discutido. Hoje, por causa da internet, o paciente sabe 
do tratamento antes mesmo de começá-lo. Por isso a importância da gente conversar, de falar a mesma linguagem, senão o paciente vai questionar. Isso foi discutido muito na nossa graduação: a gente tem que ter segurança no que fala, pois se falarmos alguma coisa diferente do que 0 fisioterapeuta falou, por exemplo, o paciente vai questionar. Ter uma visão multidisciplinar também foi bem trabalhada conosco.

Referente à questão da notificação, eu vejo que isso é uma grande dificuldade, porque a gente tem a visão de notificar os erros para, justamente, saber onde há falha no processo e melhorar a segurança do paciente, mas as pessoas têm medo de se expor e serem repreendidas. Nos estágios da faculdade discutimos com o professor quando alguma coisa não sai da forma correta, o que nos tranquiliza; mas acredito que quando formos profissionais e tivermos que lidar com uma falha na nossa equipe será mais difícil, porque as pessoas enxergam o fato como punição, pensando que vai gerar algum malefício para ela se o erro for descoberto. Na faculdade, tivemos a oportunidade de discutir e entender o sentido real da notificação de ocorrência; descobrir os erros para trabalhar em cima deles e não como punição.

Quanto ao gerenciamento do risco, acredito que é pouco trabalhado. Por exemplo, na aula de Farmacologia ensinaram por que é importante ter conhecimento sobre as reações dos medicamentos, o que seria normal ou não, e qual a conduta para isso. Em Instrumentos Básicos, aprendemos sobre a punção venosa e quais seus riscos, como a flebite. Você aprende a prevenir, a fazer a técnica correta, mas esses conceitos só são relembrados quando vai fazer a sua primeira punção venosa na prática; então, a professora relembra a técnica de punção e tudo o que pode acontecer. Mas a partir do momento que você se sente mais seguro para realizar o procedimento e o professor acredita que dependendo do semestre que está cursando já sabe fazer aquilo, não é tão relembrado.

Referente ao item qualidade, a gente vê que existe essa parte de monitoramento, de avaliação; a gente aprende a fazer e sua importância, mas não é algo que na graduação se trabalhe muito, nem na prática. Quando a gente vai para os hospitais que têm protocolos de tudo, então temos a oportunidade de aprender a analisar, mas não é um foco importante na graduação.

Nos ensinam bastante sobre a interação com o paciente, tanto na área hospitalar particular quanto na pública. Se for de hospital particular, ele vai saber muito sobre o seu estado de saúde, por ter mais condições e acesso às informações. Já na saúde pública e nos hospitais públicos, a gente aprende a se comunicar e a adequar o procedimento para a realidade desse paciente. Aprendemos a incluir os familiares e os cuidadores e a importância de verificar a condição financeira, o local que ele vive, quem é que cuida e como cuida dele. Também foi bastante trabalhado, nas questões de saúde pública, por que precisamos ter um cuidado especial com um paciente diabético, por exemplo.

A prevenção das infecções foi bastante abordada desde o princípio, em todos os momentos e em todas as matérias. A gente estava estudando Genética e já estavam falando da 
higienização das mãos. Discutimos também o assunto na matéria Prevenção de Infecção Hospitalar, onde aprendemos sobre controles específicos em Centro Cirúrgico; mas, no geral, todos os professores comentaram o tema.

No Centro Cirúrgico, aprendemos o uso de protocolos e checklist nos procedimentos e locais de realização da cirurgia; eu acho que o assunto poderia ser melhor abordado, embora seja difícil porque cada hospital tem um protocolo diferente, funciona de uma forma diferente. Então vimos a matéria nas aulas teóricas, mas é no estágio que o tema foi mais cobrado, especialmente no Centro Cirúrgico, porque lá tais procedimentos são uma realidade bem concreta e necessária.

O tema medicação foi muito discutido porque é uma dificuldade que a equipe de enfermagem tem nos hospitais, principalmente nos que não são muito tecnológicos, que não têm tudo no computador; então fica mais difícil. Por exemplo, a questão da letra e também a questão de controle, medicamento de risco, psicotrópico. Também tem a questão da dispensação e preparo do medicamento, dosagem e diluição, se é criança ou idoso. O assunto sempre foi bem abordado com a gente na graduação.

Eu deixaria como sugestão enfocar mais no curso de graduação o gerenciamento do risco clínico. Não que não seja abordado, mas não é relembrado, apenas é dado em matérias específicas. Acho que também poderiam abordar a questão do inesperado: se o inesperado acontecer no meu plantão, como devo agir? É difícil, pois como é inesperado, a gente nunca sabe o que pode acontecer. Como eu vou falar para o paciente se eu não sei? Se acontecer alguma coisa, eu saio e vou pesquisar para falar com o paciente ou eu chamo alguém? Como ou agir diante dessa situação no dia a dia?

Sobre a questão de medicamentos, sugiro reforçar a matéria de Farmacologia, apesar de os estudantes nunca quererem relembrar essa matéria porque é difícil. Acho que poderia ser diluída em outras disciplinas, como por exemplo, em Instrumentos Básicos. Explico: quando você vai fazer uma punção para medicação endovenosa, deveria ser relembrado o que é, para que serve e se tem alguma medicação que a reverta. Seria legal diluir as informações porque se é difícil na teoria, na prática é pior ainda. Como recém-formados teremos muitas dúvidas, mas seremos a referência para aquela equipe e pacientes. Então seria proveitoso que fosse sempre relembrada ao longo da graduação.

A parte de notificação a gente vê que existe, mas acho que o maior foco é na saúde coletiva, como a notificação de reação adversa à vacina, dos medicamentos feitos para os pacientes com tuberculose, AIDS, que são medicamentos controlados, e notificação de doença compulsória. Eu sei que existe no hospital, foi abordado na graduação, mas sei também porque eu trabalho na área, mas é importante enfocar a visão da não punição, do quanto melhora o processo se a gente descobre os erros. Então, acho que na graduação poderia ser discutida um pouco mais e serem trabalhadas novas formas de notificar os erros no hospital, que são os lugares mais ocultos. 
Também acho que se deva mudar um pouco a visão da enfermagem, pois quando há um erro médico, quase ninguém fica sabendo, porque todos os médicos dão um jeito de tentar consertar aquilo. Em algumas situações, isso é errado, eu entendo; mas na enfermagem, quando descobrimos que um colega errou, fazemos questão de que aquele erro seja ressaltado. É assim que funciona, então precisamos trabalhar um pouco mais a união na enfermagem. Eu tive uma experiência que me fez mudar um pouco a visão, pois percebi o quanto melhorou o processo de medicação na instituição em que trabalho após um erro grave de medicação, que levou ao óbito. Após o ocorrido o processo melhorou muito e as pessoas nem foram punidas, pois foi identificado que o erro começou na prescrição médica que levou toda a equipe a errar. Então, acho que esse aspecto também poderia ser mais discutido na graduação, pois quando a gente se formar e conseguir um trabalho, vai se adaptar ao que é oferecido; alguns princípios que aprendemos serão mantidos e outros serão adaptados, mas a gente também pode implementar princípios importantes no lugar que iremos trabalhar. Então, se a gente sair da graduação com o conhecimento de segurança do paciente e se no meu local de trabalho não existir um processo de notificação de erro, poderemos ver quais formas de implementá-lo. Isso faria a gente refletir e até a valorizar um pouco mais também a questão da melhoria de qualidade, os monitoramentos que fazemos e a importância disso tudo. Na prática, a gente vê que existe, o professor vai lá e explica, mas não é algo que a gente trabalhe depois. Minha sugestão seria trazer para a sala de aula o que vemos na prática; discutir, por exemplo, o quadro de risco de infecção ou algum evento relacionado à medicação sob vários aspectos, como os que ocorrem numa clínica oncológica ou num Centro Cirúrgico.

Eu desejo um dia que todos os lugares tenham segurança para o paciente, o passo a passo que hoje eu consigo oferecer aos pacientes de onde eu trabalho, porque a gente vê muito erro de medicação por aí, que a gente nem acredita que aconteça, aliás, que não deveria nunca acontecer. Eu acho que está muito relacionado com a estrutura que é oferecida ao profissional, que precisa de um ambiente de trabalho melhor que favoreça a segurança do profissional para que ele também ofereça segurança ao paciente; enfim, condições de trabalho adequadas, pois quando acontecem esses casos que a gente vê, eu fico me perguntando: e se fosse eu? Se fosse eu que tivesse que atender nove, dez, quinze pacientes sozinha... Isso pode acontecer comigo! Eu como enfermeira e só mais uma técnica com vinte ou trinta pacientes, é difícil... Então acho que deveria ter essa visão: como enfermeiro administrador, o que eu posso oferecer para minha equipe para favorecer a segurança do paciente? 


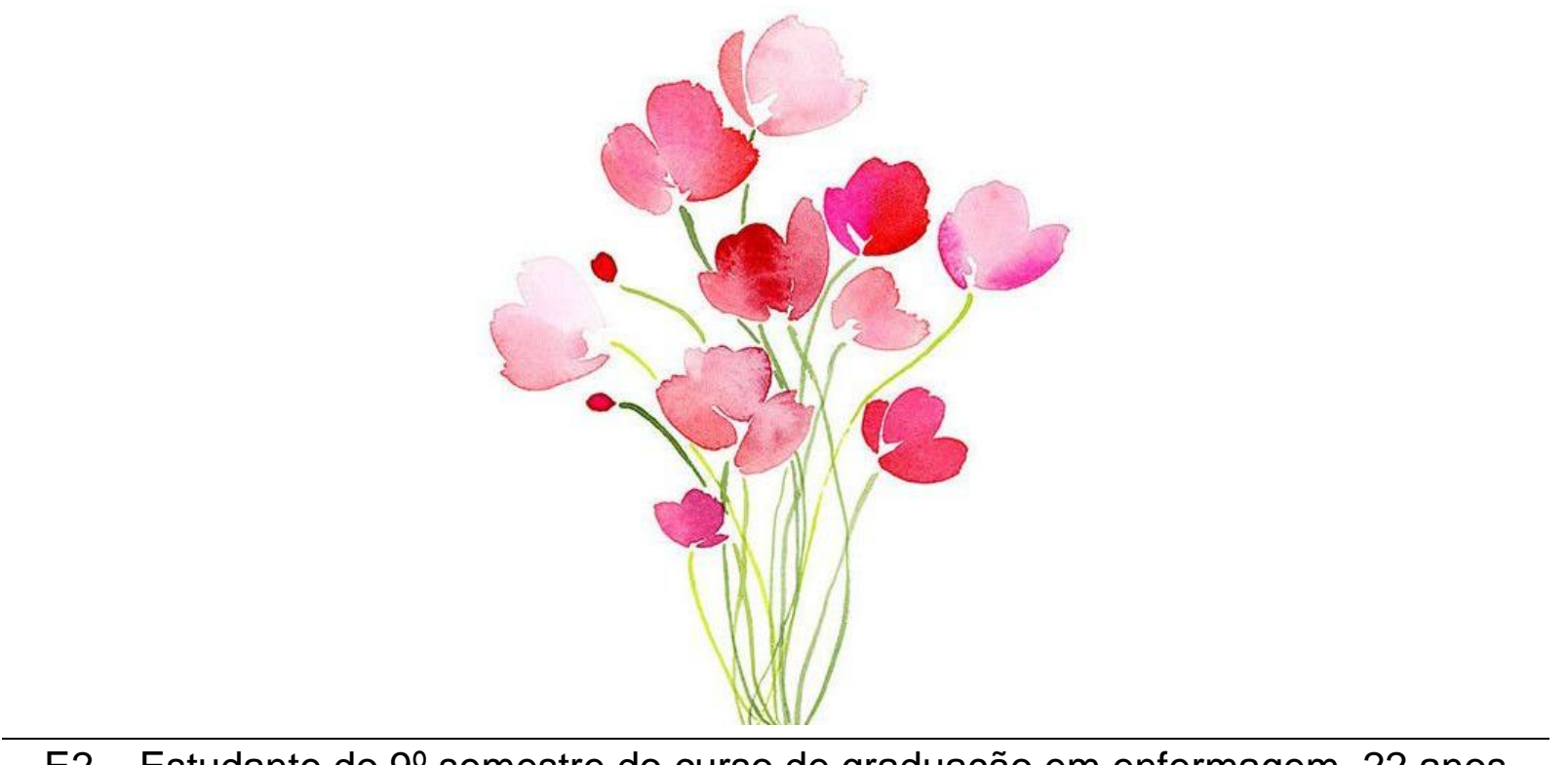

E2 - Estudante do 9º semestre do curso de graduação em enfermagem, 22 anos Data: 25/08/2016, às $12 \mathrm{~h} 30$ 

Durante a graduação em enfermagem, dá para perceber que o ensino sobre a segurança do paciente ocorre desde quando estávamos no começo da faculdade, pois em diversas disciplinas o assunto foi abordado. Eu considero a abordagem sobre segurança do paciente intensa e muito boa. A partir do momento que iniciamos os estágios assistenciais, no quinto semestre, esse assunto foi muito mais cobrado, muito mais discutido.

No que diz respeito ao primeiro tópico da OMS, sobre segurança do paciente, tivemos muita informação sobre as metas internacionais, identificação correta, comunicação efetiva, medicação certa na hora certa e todas as outras foram bem abordadas, principalmente nos estágios, quando fez mais sentido, porque ficou tudo muito mais fresco na nossa mente.

Sobre a aplicação de fatores humanos e o seu impacto na segurança do paciente não foi abordado o assunto com a gente.

Com relação a compreender os sistemas e os efeitos da complexidade no cuidado do paciente foi bastante discutido nos últimos semestres. Abordaram conosco no começo da faculdade, quando tivemos aula sobre políticas de saúde, mas essa rede e a complexidade não tinham ficado claras para mim; o que só aconteceu nesses últimos semestres, com a professora de estágio, que ajudou bastante nisso. O paciente não tem noção de onde e quando ele pode ir para receber assistência.

Referente a participar de uma equipe eficaz, não me lembro de ter discutido formalmente a importância da multidisciplinaridade, porém isso fica bem subentendido. Depois do último estágio, ficou mais evidente para mim a importância da multidisciplinaridade, pois vimos tudo o que fazem o fisioterapeuta, o estomaterapeuta, o médico...

Esse item sobre aprender com os erros para evitar danos, as não conformidades e eventos adversos, eu vi no estágio extracurricular, mas na faculdade eu não vi muita coisa sobre isso.

No que se refere a entender e gerenciar o risco clínico vimos bastante na graduação. Em Saúde do Adulto, aprendemos a fazer todas as avaliações clínicas no paciente, o que devemos ou não fazer; em Instrumentos Básicos foram abordadas as técnicas dos procedimentos e seus riscos; e os programas de monitorias que ajudam muito nos procedimentos.

No estágio, aprendi a utilizar os métodos da melhoria da qualidade para aprimorar cuidado e a importância do levantamento e acompanhamento dos dados. No meu estágio extracurricular, tive a oportunidade de fazer estatísticas e monitoramentos e também de realizar assistência ao paciente no Centro Cirúrgico.

O item interação com pacientes e cuidadores também foi mais discutido no estágio, já que interagimos com o paciente e com alguém da família No começo da faculdade, em algumas matérias que tivemos, foi destacada a importância de ter essa interação e cuidado não só com o paciente, mas com a família, até porque se a família não está bem, atrapalha a assistência ao paciente. 
O tema a respeito da prevenção e controle de infecção foi abordado durante toda a graduação, com mais foco a partir do momento em que tivemos disciplinas específicas da enfermagem, por volta do terceiro ou quarto semestre.

Em relação à segurança do paciente em procedimentos invasivos, uso de checklist $e$ protocolos eu senti falta do aprendizado quando entrei no estágio extracurricular no Centro Cirúrgico, porque só tivemos uma disciplina voltada para o perioperatório, a professora abordou bastante coisa, mas era uma disciplina muito curta. Então, em relação aos procedimentos cirúrgicos ou invasivos, o conteúdo precisa ser melhor abordado. Já os procedimentos invasivos que a enfermagem realiza, tais como passagem de sonda e punção venosa, e o passo a passo do protocolo foram discutidos na teoria, na prática e na monitoria, sempre disponível para quem quiser estudar e praticar um pouco mais.

$O$ processo de medicação e os erros para evitar danos também foram bastante abordados, pois são metas internacionais da saúde, principalmente no estágio. Tivemos nas aulas de Instrumentos Básicos e depois na disciplina de Farmacologia Aplicada à Enfermagem, então acredito que foi suficiente.

Deixo como sugestão abordar mais o segundo tópico, porque a aplicação de fatores humanos é importante para a segurança do paciente; a multidisciplinaridade também poderia ter sido também discutida de uma maneira diferente, para fixar mais a importância da equipe no cuidado ao paciente, talvez pudesse ter uma disciplina de eixo sobre segurança do paciente, com alunos de todos os cursos, como acontece em algumas disciplinas. Poderia utilizar simulação realística de eventos com o paciente contendo pessoas de diversas equipes diferentes... Eu acho que ficaria muito mais nítido para a gente a importância da multidisciplinaridade e seria bem melhor para a fixação do assunto.

A questão da notificação de eventos eu aprendi no estágio extracurricular, mas seria importante discutirmos que não é para o mal, para prejudicar outro enfermeiro ou outro setor, muito pelo contrário, serve para mantermos a assistência padronizada, diminuir os riscos para o paciente. Sobre a utilização dos métodos e melhorias da qualidade, foi bem abordado para mim, eu não mudaria nada.

Quando eu penso em segurança do paciente, o que vem à minha cabeça são as metas internacionais, é pouco comparado com o que precisamos saber para ter uma segurança efetiva do paciente, mas se soubermos bem, pelo mesmo isso, acredito que está bom. Eu me sinto seguro, porque nós aprendemos sobre tudo isso, eu consigo parar e pensar sobre o que eu posso ou não fazer, ou no que eu deveria ter feito antes e qual o impacto disso para o paciente... Com relação à segurança do paciente eu sairei da faculdade e não vou sentir carência, porque foi discutido esse assunto conosco. 


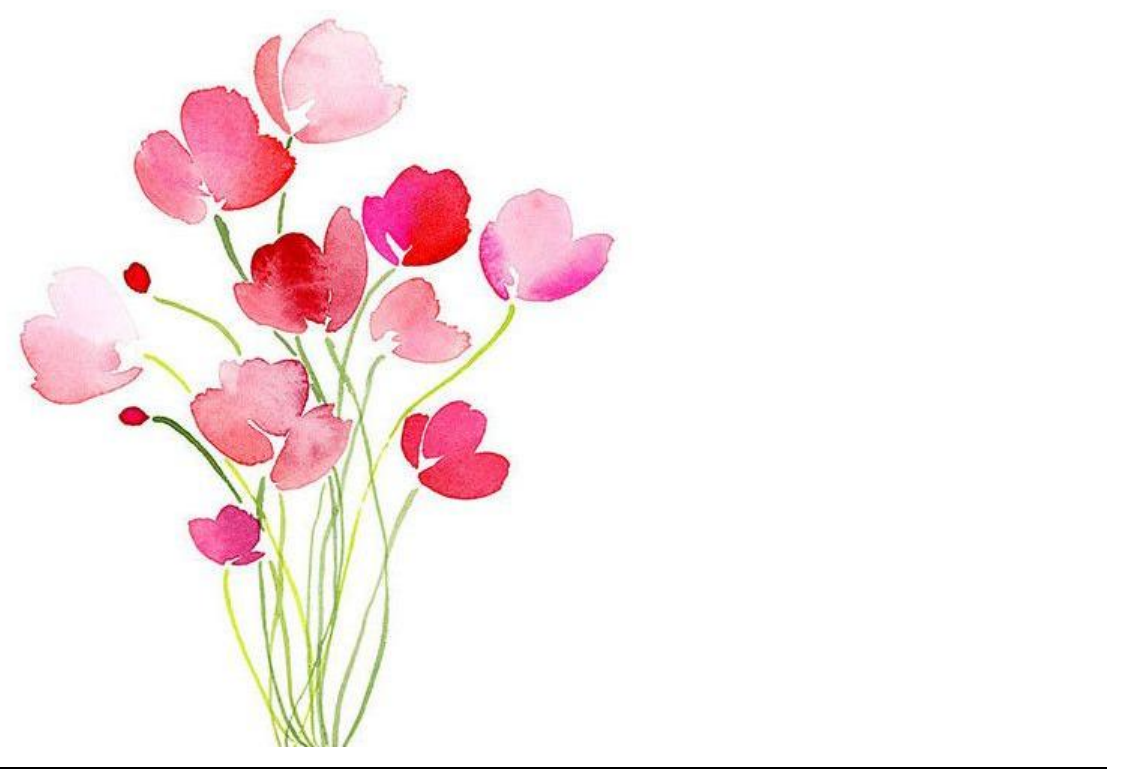

E3 - Estudante do 9ำ semestre do curso de graduação em enfermagem, 22 anos Data: 25/08/2016, às $13 \mathrm{~h} 30$ 

A segurança do paciente é abordada durante o curso de graduação, mas não em uma matéria específica; é discutida no decorrer das matérias práticas durante o curso inteiro, não de forma direta, mas é citada desde quando começamos a aprender a realizar procedimentos e compreendemos a importância de realizá-los de maneira adequada.

No que diz respeito ao primeiro item sobre o conceito de segurança do paciente, acho que é abordado sempre, mas começa quando aprendemos os procedimentos, porque é onde estamos mais sujeito a errar e o erro pode levar a consequências mais graves. Poderia ser mais discutido no processo de administração de medicação, que para a enfermagem também é muito importante.

Em relação aos fatores humanos e à tecnologia, acho que isso é importante, porque se você não souber manusear um equipamento, uma bomba de infusão, por exemplo, vai interferir no resultado final. Além disso, não só em relação aos equipamentos, mas eu, como ser humano, posso errar, eu posso acordar confusa, com um monte de problemas, ter vários empregos, ficar distraída e acabar errando. Posso preparar algo errado, ou administrar errado... São coisas que podem acontecer. Os professores falam nos estágios: "antes de entrar no quarto verifique três vezes, pergunte se tiver dúvida ou, se for preciso, revise o procedimento inteiro com o enfermeiro ou comigo, pois você tem que entrar no quarto seguro de tudo o que está fazendo". Algumas disciplinas em sala de aula também comentam sobre a possibilidade de ocorrer erros, mas é só citado. No estágio, onde fazemos os procedimentos, é mais discutido.

Quanto ao item sobre a complexidade dos sistemas, foi ensinada nas matérias de saúde pública sobre a complexidade dos pacientes: quem podemos atender em uma UBS e quais os recursos para assisti-lo. Precisamos saber se podemos tratá-lo no nosso ambiente de trabalho ou se é preciso encaminhá-lo para outro local de atendimento. Por isso, precisamos conhecer todas as unidades e serviços disponíveis, conhecer os protocolos de encaminhamento, o que fazer e com quem falar.

Sobre ser um participante de uma equipe eficaz, acredito que é pouco discutido. Tem uma disciplina que fala de relacionamento interpessoal e aborda também a importância da relação com a família, mas acho que vimos isso no estágio da área hospitalar. Por exemplo, o meu último estágio foi na UTI [Unidade de Terapia Intensiva] e percebi uma boa interação entre enfermeiro, fisioterapeuta e médico, todos trabalhando juntos. Foi só lá na UTI que eu vi isso mais efetivamente; nos outros estágios só vi a interação do enfermeiro com o técnico de enfermagem. Nesse estágio na UTI, passei bastante tempo com o enfermeiro, com os médicos, acompanhando os procedimentos deles e também com os fisioterapeutas, você precisa ter uma boa relação com todos para desenvolver o seu trabalho.

No que se refere a aprender com os erros para evitar danos, estudamos isso em relação à notificação de saúde, acidente com material biológico. Acho que a disciplina de Controle de Infecção Hospitalar citou a questão de notificar as situações para ser uma maneira de melhorar. 
Agora, sobre a notificação de um erro, uma medicação errada, por exemplo, sinceramente não sei o que fazer, eu nunca vi acontecer isso nos estágios.

No que diz respeito a entender e gerenciar o risco clínico, foi discutida na disciplina Controle de Infecção Hospitalar a importância de identificar as circunstâncias que o paciente precisa estar em isolamento, para evitar a transmissão de patógenos e o risco de contaminar outras pessoas. A orientação aos acompanhantes dos pacientes em isolamento também é importante, pois eu já vi no estágio da UTI uma acompanhante de um paciente em isolamento de contato ir conversar com o fisioterapeuta, com o médico, apoiar-se em todos os balcões, falar com o acompanhante de outro paciente e assim foi contaminando tudo. Depois que ela saiu, a gente pegou o álcool e limpou todos os lugares por onde ela passou.

A utilização de métodos de melhoria da qualidade para aprimorar o cuidado foi citada em diversas disciplinas, com mais foco em Gestão. Foi discutido sobre usar dados para saber se o processo está sendo realizado adequadamente ou não e, se não estiver adequado, quais os caminhos para melhorá-lo.

Sobre a interação com pacientes e cuidadores, o assunto é abordado de forma geral, não em uma disciplina específica, mas sempre está nas discussões de todas as matérias, porque isso é muito importante, pois às vezes a relação com a família é muito mais difícil do que a relação com o próprio paciente.

No que diz respeito às causas e tipos de infecções, nós discutimos na matéria de Controle de Infecção Hospitalar o impacto de não realizar os procedimentos de maneira adequada, desatenção, costume, fazer automaticamente e falta de atenção.

Quanto à segurança do paciente nos procedimentos invasivos, acho que todos os procedimentos que a gente aprendeu na faculdade são feitos com checklist. Primeiro saber o nome do procedimento, depois preparar a bandeja, o professor conferir a bandeja; a gente faz tudo por etapa. Também vimos os protocolos, desde o começo, passar por todos eles, fazer todas as etapas, realizar todas as etapas junto com o professor.

O item segurança no processo de medicação foi falado o tempo inteiro. Os cinco certos, que agora são 11, foram muito citados tanto nas aulas em sala e laboratório como nos estágios.

Como sugestão para abordar esse assunto na graduação, eu acho que poderia ser mais específico, não precisa ter uma matéria exclusiva, mas pelo menos um dia de aula só sobre segurança do paciente e os principais conceitos. O fator humano é sempre citado, também não tem uma matéria específica, e acho que não tem a necessidade de ter. Na minha opinião, na aula de Instrumentos Básicos poderia falar sobre segurança do paciente e abordar todos os outros tópicos, entre eles o fator humano e o manuseio das máquinas. Apesar de ser bastante relativo, porque isso eu acho que é mais a consciência do profissional, porque eu vou chegar a um hospital $X$, vai ter uma máquina da marca $X$ e no hospital $Y$ vai ter da marca $Y$ e cada profissional tem que aprender a lidar com diferentes materiais e máquinas, o ser humano precisa saber que ele não sabe tudo e que está propenso a errar... que precisa fazer as coisas com 
calma, pensar, estudar, se não tiver apto a realizar o procedimento, é melhor não fazer do que fazer uma coisa que vai dar errado. Eu acho que isso é mais da própria pessoa, não sei se tem como ensinar...

Aprender com os erros para evitar danos poderia ser mais citado durante as teorias e discutido em estágio no hospital e na UBS. Agora no final do curso dá aquele medo em relação ao futuro, mas sobre esse assunto eu me sinto segura, acredito que tenho bastante ciência do que é adequado e do que não é adequado na nossa prática profissional. 



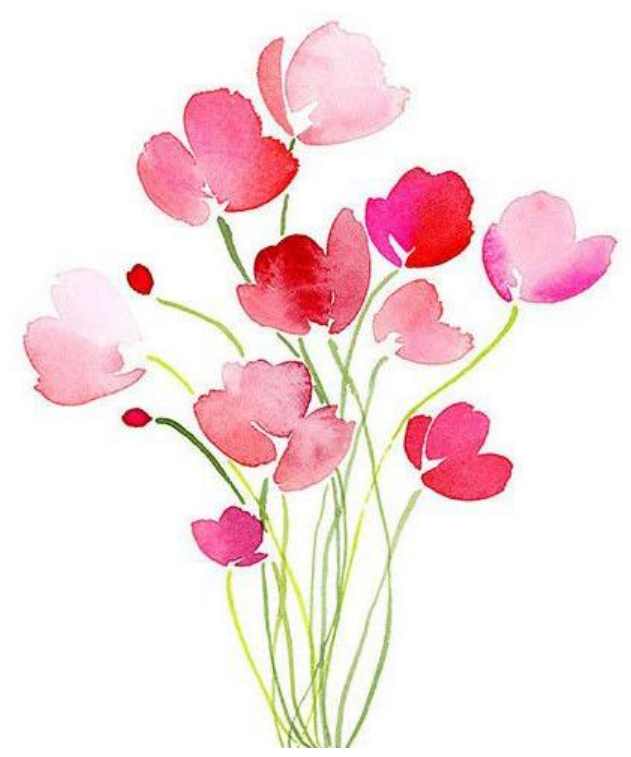

M1 - Estudante do $12^{\circ}$ semestre do curso de graduação em medicina, 24 anos

Data: 29/08/2016, às $13 \mathrm{~h} 30$ 

Na graduação pouco se fala a respeito da segurança do paciente. O que temos sobre $o$ assunto são abordagens técnicas, por exemplo, a importância da lavagem das mãos e a paramentação adequada, que indiretamente estão ligados à segurança do paciente e a prevenção de infecção. Mas o tema em si, uma discussão ampla a respeito, nunca chegamos a ter.

No que diz respeito ao primeiro item do manual da OMS, a definição do que é segurança do paciente, nunca chegamos a discutir diretamente. A identificação do paciente, eu estou vendo agora no setor de radiologia, onde acompanho a realização dos exames e observo que os profissionais chamam o paciente pelo nome e o conferem na pulseirinha no braço; mas ninguém nunca falou da importância dessa verificação, mesmo nos outros hospitais, isso nunca foi discutido, inclusive já cansamos de ver prescrições e receitas trocadas!

Com relação à aplicação dos fatores humanos, também não foi discutido; pelo contrário, sempre se coloca a culpa na outra pessoa. Por exemplo, se o técnico de radiologia fez o exame do paciente errado ou registrou errado, em nenhum momento paramos para pensar que aquele profissional pode estar com uma gripe ou cansado...

Sobre a complexidade do sistema de saúde, tivemos a organização do SUS [Sistema Único de Saúde], referência e contra referência; a UBS como entrada no sistema que encaminha o paciente para o ambulatório de especialidades que, se achar necessário, o encaminhará para o serviço hospitalar; depois, o paciente retorna para o serviço de origem. Tivemos esta parte burocrática e técnica, mas nunca discutimos sobre pensar no paciente que passará por todo esse trâmite, só percebemos que ele se perde e, às vezes, não retorna de maneira adequada.

A questão do trabalho em equipe e de incluir o paciente vivenciamos mais no internato e não nas aulas. No hospital, especialmente na UTI e na enfermaria, vimos a equipe multidisciplinar realmente funcionando, tendo reunião para discussão do paciente e toda essa importância.

Referente à notificação de incidentes, acho que nunca paramos para discutir sobre isso na graduação. No hospital, por exemplo, se você prescreveu um paciente errado, simplesmente apagava aquela prescrição e colocava outra em cima. Nunca notificamos isso como falha ou pensamos em rever o processo. É assim, bem natural, e os erros acabam até mesmo sendo encobertos. Não discutimos a questão de notificar, de ficar mais atento e resolver as falhas.

Sobre o gerenciamento de risco, o que vi um pouco mais foi em relação à alergia ao contraste em paciente submetido à tomografia, pois somos orientados sempre a perguntar se ele tem alergia a alguma coisa e se já teve alergia a frutos do mar. Em relação às outras medicações de uso rotineiro, que também podem causar alergia, não nos atentamos muito. Essa abordagem também é uma orientação superficial, um comentário para ficarmos atentos, nada de sentar para discutir o assunto.

Quanto à utilização de métodos da qualidade, não tivemos muito contato a ponto de pensar e elaborar um indicador, mas percebi que no hospital alguns indicadores recebem mais 
atenção; por exemplo, a queda, a prevenção de tromboembolismo e todo o cuidado para fazer a profilaxia adequada, mas não discutimos com esse foco de indicador, sempre foi com foco na clínica, aplicar as escalas e evitar complicações para o paciente.

Sobre a interação com os pacientes e cuidadores, discutimos mais nos extremos de idade, as crianças e os idosos, pois geralmente você inclui mais a família na discussão. 0 paciente adulto, em idade ativa, é mais complicado, nem todos os profissionais que acompanhamos sentam com o paciente, conversam e o incluem nesse processo de cuidado, alguns simplesmente passam e informam, depois viram as costas e vão embora. Não tivemos essa discussão durante a formação; a maioria das experiências em relação a isso ocorreu no internato, dentro do hospital.

A prevenção de infecção foi abordada durante toda a graduação. Começou com as enfermeiras, que falaram da lavagem das mãos, depois voltamos ao assunto nas aulas Infectologia e na disciplina de Cirurgia e Técnicas Cirúrgicas. No internato, também é exaustivamente explicada: o serviço de CCIH [Comissão de Controle de Infecção Hospitalar] do hospital insiste na importância da lavagem de mãos antes e depois de ter o contato com o paciente; não ir de um paciente para outro sem ter lavado a mão ou usar o álcool gel.

Em relação à segurança nos procedimentos invasivos, a lateralidade foi bem abordada. Tudo que tem direita e esquerda dá problema, precisa verificar o lado correto. Isso foi falado na faculdade e no hospital novamente. Acabei vendo mais o pessoal da enfermagem fazendo isso do que nós mesmos. Geralmente no pré-operatório o médico passa e o interno vai atrás e verifica o lado, mas quem faz a marcação, indica naquele boneco do prontuário que tem desenhado a lateralidade, é a enfermagem. Os médicos negligenciam um pouco isso e confiam... Se uma perna está exposta e a outra coberta, então é porque é na exposta que o procedimento deve ser feito, eles não conferem antes de iniciar o procedimento. Nem quando tivemos Técnicas Cirúrgicas o tema foi abordado, pois tivemos lavagem de mãos, paramentação adequada, sutura... A parte da cirurgia segura não foi discutida. No hospital privado onde passamos para acompanhar a anestesia era outra realidade, tinha protocolo, mas no nosso hospital escola, SUS, percebemos que muita coisa passa batido.

Nesse item sobre medicação, a letra é um grande problema. No internato tivemos professores que valorizavam que a letra estivesse bonita, o nome do medicamento sempre em letra de forma para o paciente entender; devíamos explicar como tomar, se o paciente era analfabeto tinha que fazer um esquema numa outra folha, mas tem outros preceptores que não se preocupam com isso. Depois, nem o farmacêutico entende e o paciente não toma direito a medicação. Os professores das áreas que lidam com pessoas mais idosas, a geriatria e a cardiologia, sempre ficavam bem atentos se estávamos fazendo o receituário com letra legível e se o explicávamos ao paciente com atenção.

Como sugestão para a abordagem desse assunto, acredito que todos os tópicos apresentados no manual poderiam ter sido discutidos em conjunto. Talvez na nossa entrada no 
internato, quando temos contato, de fato, com o paciente. Porque tudo que tivemos foi fragmentado, com uma informação aqui, outra observação ali... Veríamos tudo em um único momento, não que não deva ser falado nas outras disciplinas, antes do internato, onde o aprendizado seria complementado. Na minha opinião, os itens sobre o processo de prescrição da medicação, a segurança nos procedimentos invasivos e o controle de infecção são essenciais. Além disso, é interessante falar sobre a equipe multidisciplinar e a identificação do paciente. 



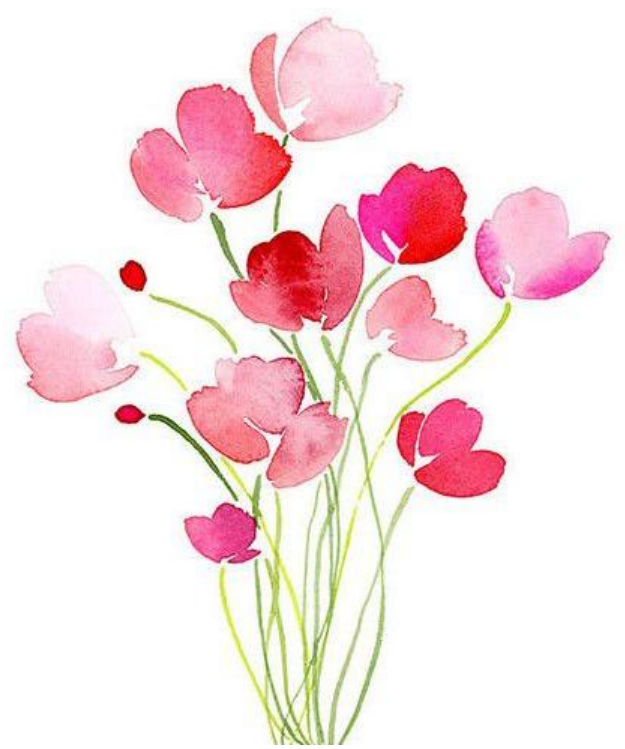

M2 - Estudante do $12^{\circ}$ semestre do curso de graduação em medicina, 25 anos

Data: 30/08/2016, às $14 \mathrm{~h}$ 

Eu acho que o assunto segurança do paciente aparece de uma forma menos presente do que eu imaginava. É abordado sempre como pano de fundo, raramente como temática principal. Discutimos essa questão na disciplina de Medicina do Trabalho, voltada para o trabalhador e não para o paciente. Eu esperava que na disciplina de Emergência, por exemplo, a segurança do paciente estivesse mais presente. Acabamos aprendendo muita coisa através do relato dos preceptores, das situações e experiências que eles passaram e nos contaram. Falta uma abordagem mais direta sobre o assunto. Poderíamos ter três aulas no semestre para essa finalidade, pois o tema foi fragmentado em algumas disciplinas.

No que diz respeito aos itens da OMS, o conceito de segurança do paciente foi abordado no primeiro ou segundo semestre. É muito precoce discutir isso no início da faculdade. Além do mais, a abordagem que se dá quando falam está relacionada à prevenção de processos judiciais. Por exemplo, a parte de deixar tudo bem descrito no prontuário é muito mais com enfoque na segurança do médico que na do paciente.

Sobre a complexidade do sistema de saúde e a integração dos serviços do SUS, deveríamos ter visto em Saúde Pública, mas a minha turma não teve essa disciplina. Estamos aprendendo alguma coisa agora na prática, mas não tivemos na teoria.

Em relação aos fatores humanos, durante os quatro anos vimos pouco, mas agora no internato vivenciamos bastante o médico se posicionar para o paciente, explicando sobre as possibilidades, as incertezas e dizendo: pode ser que dê certo, pode ser que não dê, porque não tem como sabermos tudo, as coisas acontecem não de forma proposital, simplesmente acontecem.

No que se refere ao item quatro, trabalho em equipe, temos bastante discussão sobre $o$ tema, principalmente no internato. Antes disso, no primeiro ou segundo ano, a questão da equipe multidisciplinar é abordada, mas não temos muita dimensão de qual é o nosso papel naquele momento; entendemos o conceito, porém ainda não fazemos parte de nenhuma equipe. Agora, no internato, ao participarmos de uma equipe, conseguimos avaliar os prejuízos dos serviços onde isso não acontece. Nós percebemos a importância do trabalho em equipe na conduta do médico da UTI ao ouvir a fisioterapeuta e a enfermeira, assim como a enfermeira vai ouvir os outros, vai discutir com a equipe multidisciplinar algum caso.

Quanto à notificação de eventos ou de acidente, nós sabemos que existe, mas há uma falha na graduação, pois não sabemos muito bem o que precisamos notificar nem como notificar um acidente com material perfuro cortante, por exemplo. Na aula de Infectologia apenas soubemos que precisa notificar. Em relação ao erro com paciente, isso nunca foi discutido, mas eu não vi nenhum erro grotesco, as poucas situações que eu vi, foram em posto de saúde e que conseguimos contornar.

Em contrapartida, o gerenciamento do risco clínico é mais estudado; todas as especialidades falam do assunto, bem segmentado e com foco na sua área. O tema medicação também foi bastante abordado. Aprendemos a importância de explicar ao paciente como utilizá- 
la: no caso de um medicamento inalatório, por exemplo, é preciso pedir que o paciente faça o primeiro uso na sua frente, para ele não aplicar errado. É óbvio que encontramos pessoas que não têm tanto tato, mas eu encontrei profissionais que explicavam o que era necessário fazer com o paciente, a necessidade do exame, o motivo daquele procedimento, da prescrição do medicamento e o que pode acontecer com o paciente.

No que diz respeito à qualidade do cuidado e indicadores, vimos muito isso em $\mathrm{CCIH}$ no hospital, pois ali fazem o monitoramento e as equipes recebem feedback sobre a questão da otimização da medicação, troca de antibiótico... Sobre os outros monitoramentos que existem, vimos pouco, um ou outro professor trazia alguma coisa de fora para comentar.

Referente à interação com o paciente e cuidadores, nem todas as especialidades abordaram a questão do cuidador. Na Geriatria e na Oncologia falaram sobre como tratar o cuidador, seu estresse do cuidador... Na Pediatria foi discutido sobre a necessidade de, em alguns momentos, o médico solicitar que a pessoa que cuida da criança, seja a avó ou a babá, vir à consulta para poder explicar o que deve ser feito no tratamento.

Em compensação, aprendemos muito sobre infecção já a partir do primeiro ano, depois na infectologia e no hospital: a primeira aula do internato é sobre a lavagem de mãos e prevenção de infecção. $O$ assunto é abordado de várias maneiras, na teoria e na prática. $A$ questão de isolamentos, paramentação e risco de infecção cirúrgica vimos mais no dia a dia do hospital durante o internato.

Sobre a questão de segurança em procedimento invasivo eu, particularmente, acho muito falho, porque você dá um termo e não dá nem tempo para o paciente ler com calma e assinar e já o anexa ao prontuário. Presenciamos isso no internato na área hospitalar durante o estágio de cirurgia. A questão de demarcação do sítio cirúrgico, vimos que algumas especialidades marcam o paciente, como a vascular e a plástica, então os pacientes chegam ao Centro Cirúrgico marcados.

O item processo da medicação foi bastante estudado, desde o primeiro semestre, quando aprendemos os trâmites da distribuição do remédio na UBS, porque a orientação é sempre prescrever o medicamento que pode ser encontrado na UBS: no internato, somos nós mesmos quem aviamos a receita. Aliás, tivemos uma aula sobre a receita ser legível, a necessidade de explicar a receita ao paciente, mostrar o comprimido e até desenhar se for preciso. Já vi professor que rasgou a receita porque não dava para ler... Então, ou refaz ou usa o computador.

Em relação à notificação, sugiro que fossem abordadas as questões: o que eu preciso notificar para mim, como médico, e o que preciso notificar para o paciente? Eu notifico que me furei na cirurgia e o paciente era HIV? Qual é o meu segmento? Eu tenho que fazer exame seriado? E o paciente, ele sabe ou não que tem doença? Eu conto ou não conto? É a CCIH que se responsabiliza por isso? 
No que se refere aos outros itens, a parte dos fatores humanos e inter-relações, acho que foram bem abordados, mesmo não tendo uma coisa específica. De modo geral, foi satisfatória a abordagem sobre a interação com os cuidadores, a medicação, a lavagem de mãos. A questão da prevenção infecção ficou falha em relação ao isolamento, nos ensinaram todo o conceito em Microbiologia, mas tem muita coisa e no internato, quando tivemos que fazer na prática, ficamos um pouco inseguros. O que eu uso? Como me paramento?

Também seria interessante falar sobre o que é segurança; poderia ter uma disciplina para isso, porque não estudamos diretamente esse assunto: aprendemos ouvindo, vendo e percebendo alguns fatos, mas não formalmente. Vimos alguns conceitos na saúde do trabalhador que podem ser aplicados ao paciente, mas não é a mesma coisa. 



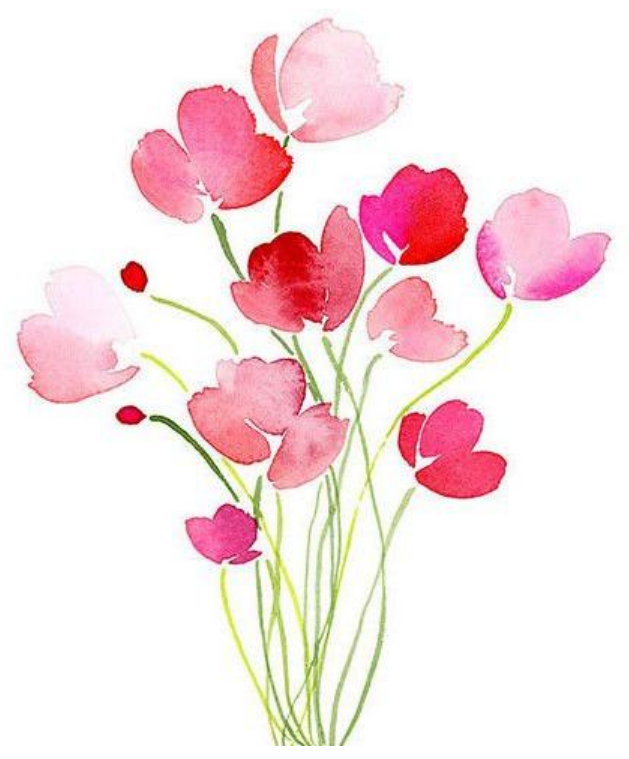

T1 - Estudante do 6ำ semestre do curso de graduação em terapia ocupacional, 21 anos

Data: 31/08/2016, às $11 \mathrm{~h} 30$ 

Até hoje eu não tive nenhuma matéria especifica para falar sobre segurança do paciente. A professora dá dicas baseadas na experiência dela. Ontem mesmo eu tive uma aula de transferência do paciente no leito e eu relacionei a segurança do paciente com a grade elevada da cama para o paciente não cair, por exemplo.

Sobre os tópicos do guia da OMS, o primeiro, o que é segurança do paciente, eu não tive; só foi comentado superficialmente ou em visita técnica em algum hospital, quando o professor falou rapidamente sobre algo.

No que concerne ao segundo tópico, nós tivemos aula de Saúde do Trabalhador e discutimos sobre como o espaço influencia no trabalho, mas não era em relação ao paciente e sim ao trabalhador e como ele pode se tornar um paciente por conta da sua relação com o ambiente de trabalho.

Em relação ao terceiro tópico, estamos aprendendo como funciona o nosso sistema de saúde, as esferas de atuação, como funciona cada uma e a relação entre elas, mas ainda não discutimos e nem sei se discutiremos como fazer o encaminhamento de um local para outro e como ter certeza de que o paciente vai chegar até lá.

O quarto tópico, a importância da equipe multidisciplinar, foi discutido em vários semestres. É importante que ocorram as reuniões de equipe para discutir como cada profissional pode colaborar no cuidado do paciente. A terapeuta ocupacional nunca estará sozinha, sempre trabalhará com a fonoaudióloga ou com a fisioterapeuta para atender a todas as complexidades do paciente.

No que diz respeito ao quinto tópico, nós aprendemos que é necessário registrar tudo no prontuário do paciente para todos os profissionais terem acesso ao que foi realizado, tanto para a segurança dele quanto para a nossa. Mas nunca foi falado sobre registrar o erro em algum outro local além do prontuário, nem sabia que existia isso.

Em relação ao sexto tópico, nas aulas práticas nós tivemos sobre os riscos que a terapia pode gerar ao paciente e como devemos lidar com isso, uma órtese que adaptamos para o paciente, por exemplo. Também nas aulas de contextos hospitalares, a professora deu exemplos do que o paciente pode solicitar quando fazemos um atendimento e, como não o conhecemos muito bem, ensinaram que, antes de Ihe atender, devemos consultar a enfermagem, pois se 0 paciente, por exemplo, pede para beber água, não sabemos se ele pode ou não, se vai ter algum risco.

No que se refere ao sétimo tópico, aprendemos nas disciplinas de Epidemiologia e Bioestatística a interpretar os gráficos; na Terapia Ocupacional utilizamos alguns gráficos e índices para avaliação funcional do paciente, não com o foco em gestão da qualidade.

O oitavo tópico foi bastante abordado durante a graduação. Aprendemos como incluir os cuidadores e a família no processo, tanto no ambiente hospitalar como domiciliar; é o cuidador quem vai ficar com o paciente a maior parte do tempo, então ensinamos o cuidador como fazer, como continuar o tratamento em casa. Foi discutido como incluir a família nos cuidados: por 
exemplo, no caso de uma criança, às vezes o familiar está sofrendo mais do que a criança, que não está entendendo o que está acontecendo. Então, conversamos para formar o vínculo entre $o$ paciente e a família.

Sobre o nono tópico, ensinaram, em diversas disciplinas básicas e específicas, a necessidade da higienização das mãos do profissional e do paciente, a maneira correta de se utilizar um brinquedo e quais os mais indicados em relação à limpeza: plásticos ou similares; nunca pelúcia ou madeira.

No que diz respeito ao décimo tópico, aprendemos alguns protocolos para fazer a avaliação do paciente e verificar se o que paciente está dizendo condiz com a avaliação, mas precisamos nos atentar para fazer a avaliação do lado correto, de acordo com a necessidade do paciente.

No último tópico, na aula de Farmacologia, apesar de não administrarmos medicamentos, o professor falou que precisamos ler a receita para o paciente, verificar se ele entendeu tudo, pedir que ele repita para ter certeza, ou seja, fazer alguma coisa para tirar suas dúvidas ou do cuidador. Outro ponto discutido foi de não compreender o que está escrito no pedido médico, então devemos conversar com outro profissional para ver se ele entende ou entrar em conato com o médico.

Como sugestão para abordagem do assunto segurança do paciente na graduação, acredito que o primeiro tópico seja o mais importante. Precisamos ter aulas sobre segurança do paciente, as definições básicas e os conceitos, pois tivemos fragmentos do assunto, que me parece ser bem mais amplo. Eu acho que o tema devia ter sido abordado como disciplina de eixo para todos os cursos juntos e depois, em cada disciplina, os professores aprofundariam a discussão nas suas especialidades, com suas experiências. De um modo geral, acho que a segurança do paciente é pouco discutida. 


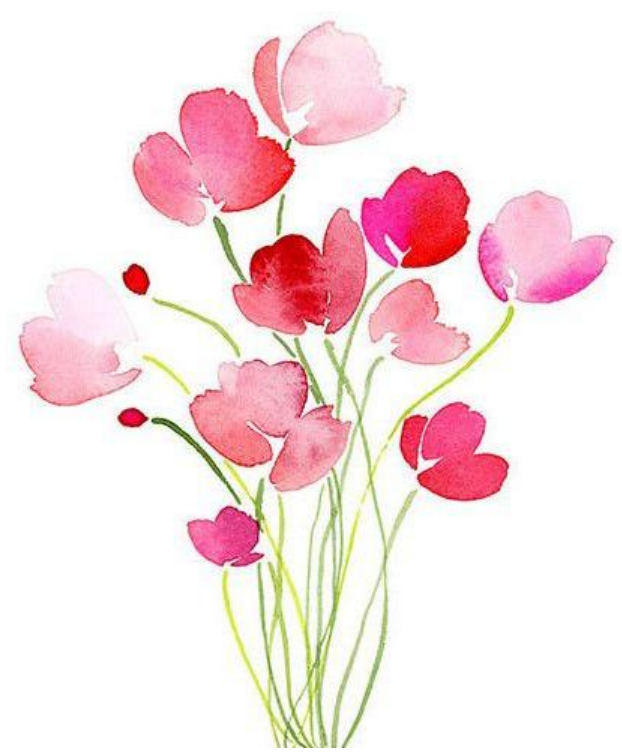

T2 - Estudante do 6ำ semestre do curso de graduação em terapia ocupacional, 27 anos

Data: 05/09/2016, às $13 \mathrm{~h}$ 

Eu não consigo me lembrar de ter sido muito abordado o assunto segurança do paciente. Algumas disciplinas ensinam alguns procedimentos e abordam alguns assuntos que eu acredito que estão relacionados à segurança do paciente, mas isso não foi discutido diretamente.

No que diz respeito aos tópicos do guia curricular da OMS, o primeiro eu não me recordo de ter sido mencionado em nenhuma disciplina.

O segundo tópico também não. A relação do ambiente e sistemas com a segurança do paciente, com erro humano não foram estudadas; tivemos, sim, a questão da ergonomia com foco na saúde do trabalhador.

Sobre o terceiro tópico, na disciplina de Saúde Pública, foi explicado como nosso sistema está estruturado, mas não relacionamos isso com a segurança do paciente, apenas aprendemos como o SUS funciona.

Em relação ao quarto tópico, a questão de trabalhar em equipe foi discutiva desde o início da graduação, quando cursamos as disciplinas de eixo e entramos em contato com outros cursos. Nas disciplinas específicas, o tema também foi abordado de diversas formas.

No que concerne ao quinto tópico, também não me recordo de termos discutido que é importante notificar uma falha que ocorreu. Aprendemos algumas atitudes que devemos ter para não ocorrer falhas como, por exemplo, levantar a grade da cama para o paciente não cair.

O sexto tópico é discutido um pouco nas aulas práticas, quando a professora ensina alguma técnica, alguma atividade e fala que temos que ter cuidado com determinadas coisas; mas não é assim tão específica para explicar: se fizer isso pode colocar o paciente em risco.

No que se refere ao sétimo tópico, também não me lembro de aprendermos sobre qualidade do cuidado.

O oitavo tópico foi muito discutido em várias disciplinas, envolver e ensinar o paciente, $o$ familiar ou cuidador no tratamento é fundamental para o sucesso e a melhora do paciente nas atividades.

Em relação ao nono tópico, o assunto foi bastante abordado, tanto nas disciplinas de eixo, no começo da faculdade, como nas disciplinas específicas. Especialmente a questão de higienização das mãos no contexto hospitalar e a higienização dos materiais e brinquedos que utilizamos.

Sobre o décimo tópico, no começo da faculdade discutimos um pouco o uso de protocolos em uma disciplina de eixo chamada Cuidados em Saúde. Aprendemos os protocolos gerais, inclusive higienizar as mãos e os materiais que usamos, e também que cada instituição tem protocolos que devemos seguir.

No que se refere ao último tópico, em Terapia Ocupacional nós não temos muito contato com os medicamentos; podemos apenas orientar algum ponto bem básico sobre isso.

Fiquei pensando, depois de ter conhecido esses tópicos, como é fraca a minha formação nesse assunto realmente muito importante. Por isso, sugiro que o ensino da temática segurança do paciente poderia ser uma disciplina de eixo, oferecida no início da faculdade, que trouxesse 
os conceitos básicos sobre o assunto para todos os cursos da área da saúde; depois cada um teria suas disciplinas específicas, que discutiriam mais alguns pontos.

O primeiro tópico [o que é segurança do paciente], por exemplo, é o básico para todos os profissionais, poderia ter nessa disciplina de eixo. O segundo tópico também é importante: tentar entender como alguns erros podem sofrer influência do ambiente. Quando discutimos sobre SUS, não focamos na segurança do paciente e na dificuldade dos encaminhamentos e do acesso ao paciente ao tratamento e o impacto disso na segurança dele.

Acho que seria interessante discutir que os profissionais erram e que isso pode acontecer com qualquer um. Então se eu errar, o que tenho que fazer? Tenho que notificar? Tenho que acompanhar por indicadores? Como as instituições acompanham essas notificações? Quais são os maiores problemas de segurança do paciente no contexto hospitalar?

Talvez esteja faltando uma disciplina para incorporar esse assunto em algum momento da nossa vida acadêmica, porque eu só parei para pensar em segurança do paciente agora que conversamos sobre isso e percebi o quanto é importante. 




$\mathrm{N} 1$ - Estudante do $8^{\circ}$ semestre do curso de graduação em nutrição, 27 anos

Data: $12 / 09 / 2016$, às $14 \mathrm{~h}$ 

Durante as disciplinas clínicas, temos essa abordagem do paciente e são discutidos os cuidados com ele, mas acho que no estágio foi onde eu tive a maior vivência e pude realmente observar como é o dia a dia, tanto do cuidado da enfermagem, da terapia ocupacional, dos fisioterapeutas, da equipe multiprofissional como um todo. Não me lembro de ter discutido especificamente sobre segurança do paciente nas aulas; no estágio hospitalar é que temos mais contato.

No que se refere ao manual da OMS, o primeiro tópico nós vimos no estágio: a identificação do paciente. Você entra no quarto e precisa identificar o paciente, mesmo que o esteja vendo todos os dias, precisa conferir a pulseirinha com o nome.

Sobre o segundo tópico, nós discutimos na graduação a questão de serem pessoas que estão trabalhando e que às vezes não estão muito bem, então não prestam atenção em algo, mas a facilidade do sistema diminui muito o risco, a chance de erro e a necessidade de verificar mais de uma vez aquilo que você está fazendo.

Em relação ao terceiro tópico, em saúde pública falamos muito sobre o SUS, os atendimentos nas UB, porém, pouco foi discutido sobre segurança do paciente.

No que diz respeito ao quarto tópico, abordamos em aula a importância dos outros profissionais da saúde e no estágio vivenciamos as reuniões feitas diariamente para acompanhamento dos pacientes.

Concernente ao quinto tópico, acabamos vendo isso no estágio, onde foi discutida a importância de notificar as falhas para melhorar o trabalho e evitar que aconteçam novamente.

Referente ao sexto tópico, nós discutimos, por exemplo, sobre o paciente alérgico. É a enfermagem que acaba avisando a nutrição quando realizam o histórico do paciente.

O sétimo tópico foi abordado um pouco em sala de aula; no estágio aprendemos sobre o indicador de satisfação, um dos maiores da nutrição.

A abordagem com o paciente, os cuidadores e acompanhantes, oitavo tópico, é muito discutido na faculdade e no estágio também. Às vezes não é o paciente quem vai cozinhar, é o acompanhante, então tem que explicar para ele, como adaptar a consistência da dieta, por exemplo.

No que se refere ao nono tópico, aprendemos desde o começo da faculdade e no estágio novamente sobre a higienização das mãos e o trabalho na cozinha para evitar infecção.

Em relação ao décimo tópico, foi discutida a questão da conferência, da identificação correta. Nós não fazemos procedimentos invasivos, apenas tivemos algumas discussões sobre casos que aconteceram.

Também discutimos na sala de aula e no estágio o último tópico, mas relacionado às prescrições de dieta. Por exemplo, em relação ao paciente que tem disfagia: se não concordamos com alguma prescrição, devemos falar com a enfermagem, que tem contato direto com o médico, com o próprio médico e com a fonoaudióloga para discutir a consistência da dieta. 
Como sugestão para abordar esses tópicos durante a graduação, acho relevante discutir um pouco mais sobre a identificação do paciente, pois o nutricionista lida também com o copeiro e quando ele entra no quarto, tem que saber identificar e seguir o procedimento corretamente.

Talvez essa parte de risco clínico também poderia ser mais reforçada, o risco de alguns alimentos para determinadas patologias.

Outro ponto importante seria falar sobre checklist ou protocolos para garantir a entrega correta da dieta pelos copeiros, pois normalmente este é o contato da nutrição com o paciente.

De um modo geral, acredito que no nosso curso temos bastante oportunidade de discutir a questão do cuidado e da segurança do paciente na sala de aula com os professores que nos trazem suas experiências, além da prática no estágio hospitalar. 


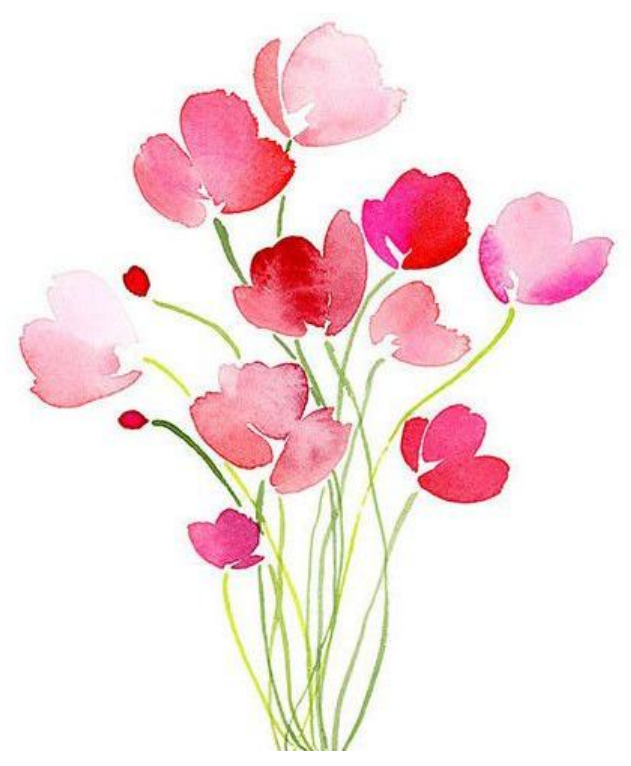

N2 - Estudante do 8ำ semestre do curso de graduação em nutrição, 23 anos

Data: 12/09/2016, às $15 \mathrm{~h}$ 

Nas matérias e nas aulas práticas, desde o primeiro semestre, é falado sobre os cuidados com paciente, mas não me recordo de ter aprendido o conceito sobre segurança do paciente. Não teve nenhuma aula formal sobre isso, mas o cuidado que temos que ter com o paciente foi abordado em diversas disciplinas.

Com relação aos tópicos do manual da OMS, o primeiro, que fala das definições de segurança do paciente, eu não tive.

Sobre o segundo tópico, não me recordo de ter sido discutido, mas entendo que alguns desses fatores são emocionais e podem atrapalhar o trabalho, pois a gente pode não ter acordado bem naquele dia, mas não me lembro de ter presenciado nada a esse respeito. Em relação aos sistemas, eu acho primordial o uso adequado, pois facilita bastante o trabalho do nutricionista, pois em um hospital geral, com característica cirúrgica, tem muita rotatividade de paciente, então se a dieta e os suplementos são inseridos no sistema, a nutricionista clínica pode ver e liberar rapidamente.

A respeito do terceiro tópico, nós tivemos uma disciplina que falava do SUS, das esferas de atendimento e políticas de saúde, mas não relacionamos isso com a segurança do paciente.

No que se refere ao quarto tópico, foi abordada a importância da equipe multiprofissional tanto nas aulas práticas como nos estágios, pois precisamos trabalhar junto com a produção para mandar a melhor refeição para o paciente; com a enfermagem para saber se está aceitando bem ou não aquela dieta; com o fonoaudiólogo para saber a melhor a consistência; e com o médico que prescreve a dieta.

Sobre o quinto tópico, eu vi um caso no hospital onde faço estágio; a nutricionista clínica precisou sair mais cedo e a nutricionista de produção teve que liberar uma dieta e cometeu um erro ao enviar a dieta para o paciente errado; então, ela notificou o incidente e eu pude ver, na prática, como devemos agir, pois ela não se envergonhou do erro, apenas identificou a falha e notificou para evitar que acontecesse novamente. Na sala de aula as professoras comentam que devemos ser sinceros com o paciente e mesmo na ocorrência de uma falha, precisamos admitir e tentar achar uma solução.

No que diz respeito ao sexto tópico, também foram abordados os riscos do paciente em relação à dieta: quando existe alguma intolerância ou alergia precisamos conversar com o médico ou quando percebemos algum problema em relação à consistência da dieta precisamos conversar com a fonoaudióloga e com o médico para utilizarmos espessantes e o paciente não correr o risco de engasgar, por exemplo.

Quanto ao sétimo tópico, só discutimos o indicador de satisfação do paciente em relação às refeições.

Em referência ao oitavo tópico, a interação com o paciente é fundamental. Aprendemos sobre o assunto tanto na faculdade quanto no estágio. Sem conhecer o paciente, não conseguimos trabalhar de verdade: às vezes, só uma visita, para perguntar como ele está, se teve uma boa aceitação nas refeições ou se podemos ajustar alguma coisa, pode fazer muita 
diferença para o paciente. Envolver quem cuida também é importante, pois muitas vezes não é o próprio paciente quem prepara os alimentos.

Com relação ao nono tópico, aprendemos na faculdade e também nos estágios sobre o controle de infecção. Em todos os andares do hospital esse controle existe; se você vai falar com o paciente, precisa verificar se tem alguma restrição. A higienização das mãos, dos produtos, a procedência do alimento, como deve ser armazenado e muitas outras coisas são observadas para evitar contaminação. Quando estamos na produção, precisamos verificar como o alimento está sendo preparado, como será enviado ao paciente, verificar o uso de máscara e luva, a limpeza com álcool das mãos, dos utensílios e das bancadas.

O décimo tópico foi discutido nas disciplinas os protocolos sobre as dietas, a montagem das bandejas e a entrega para o paciente correto quando a copeira precisa confirmar o nome completo dele. A nutricionista deve sempre olhar no sistema se a dieta foi alterada, verificar se o paciente não mudou de quarto. Existe um protocolo de aceitação da dieta que precisa ser feito com o paciente. Nós aprendemos na faculdade, mas acredito que cada hospital tem um jeito particular de realizar tudo isso.

No que se refere ao último tópico, a abordagem foi principalmente em relação à dieta enteral, que começa pela prescrição do médico, depois passa para o profissional da farmácia liberar e segue para a nutrição, que verifica se é a dieta que o paciente realmente necessita, e só depois vai para a enfermagem administrar.

Minha sugestão para abordar os tópicos da OMS na graduação é que seria interessante discutir mais sobre os fatores humanos, pois somos pessoas que cuidam de outras pessoas e há muitos fatores, emocionais principalmente, que podem interferir no trabalho diário. 


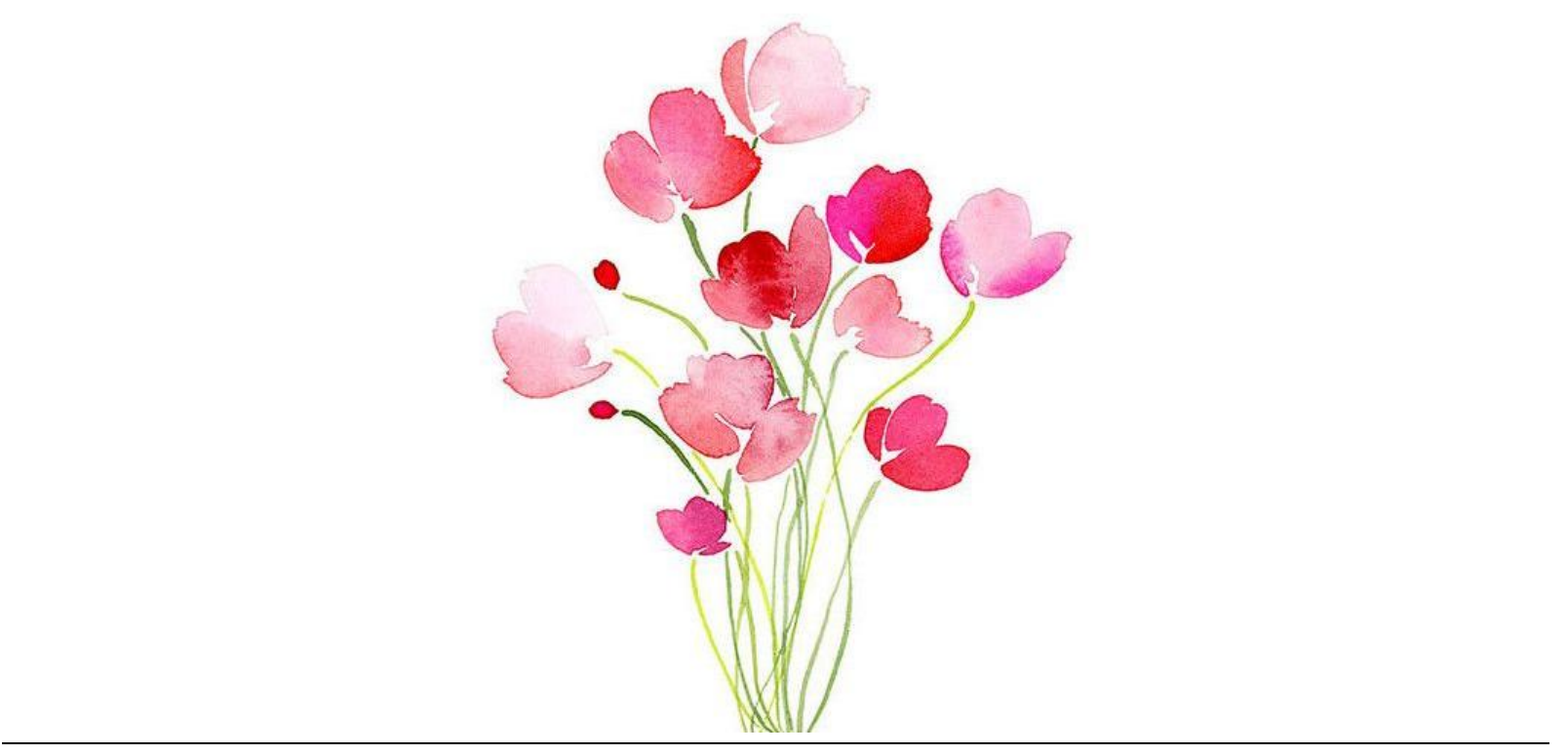

M3 - Estudante do 12 semestre do curso de graduação em medicina, 27 anos

Data: $14 / 09 / 2016$, às $13 \mathrm{~h}$ 

Na graduação, a segurança do paciente em si é mais abordada no começo do curso, em disciplinas que temos com enfermeiras. Quando entramos na parte de ambulatório, não é mencionada a segurança do paciente em si, mas, sim, a segurança do médico, para ele não ter contato com algumas doenças e coisas assim. No internato, os professores acabam se voltando um pouco mais para esse ponto, principalmente em relação à infecção hospitalar: não deixar um paciente que está com uma bactéria multirresistente perto de outro que não a tem. Durante o curso, o assunto segurança do paciente foi aparecendo em algumas disciplinas, mas não me lembro de discutir isso formalmente.

Em relação aos tópicos da OMS, o primeiro, nós tivemos no início do curso, a respeito da identificação e as cores das pulseiras: uma cor é risco de queda, outra, broncoaspiração, e assim por diante. Sobre os conceitos do que é segurança do paciente eu não me lembro de ter sido abordado.

Quanto ao segundo tópico, eu vi na prática que isso realmente acontece. Os profissionais, principalmente os técnicos de enfermagem, fazem muitos plantões de 24 horas e saem direto para outro serviço, fato que, com certeza, pode acarretar maior risco. Percebi isso na prática, não tive uma aula falando sobre o assunto.

O terceiro tópico foi abordado na aula sobre políticas de saúde e SUS, quando se falou de referência e contra referência. Na prática, já fazemos isso no hospital: quando o paciente chega ao pronto socorro apresentando alguma patologia que pode ser acompanhada pela UBS, fazemos a contra referência para acompanharem lá, ou vive versa, a UBS a encaminha para o hospital. Eu acho que na teoria isso é muito bom, mas na prática o paciente não fica tão seguro. É óbvio que se tudo funcionasse, seria um mundo ideal; no papel isso é lindo e o paciente sentese totalmente seguro, mas na prática o que acontece é que o paciente vai da UBS para o hospital e chegando lá não tem vaga e nem como atendê-lo. Ou, ainda, um paciente chega na UBS enfartando; no papel, o procedimento é chamar o SAMU [Serviço de Atendimento Móvel de Urgência] para levá-lo ao hospital, mas isso não acontece, apenas falam para ele procurar o pronto socorro! A gente não atende aqui e dispensa o paciente ali.

No que se refere ao trabalho multiprofissional, vivenciamos na prática, principalmente no CAPS [Centro de Atenção Psicossocial], onde tudo era multidisciplinar: tem médico, psicólogo, terapeuta ocupacional, fisioterapeuta e enfermagem. Todos decidem, só que tem hora que, dependendo de cada caso, o médico deveria ter mais autonomia, em outras, a psicóloga... É muito interessante na UTI, onde, pelo menos na experiência que eu tive, a equipe multiprofissional trabalha muito bem: médico, fisioterapeuta e fonoterapeuta trabalhando juntos em benefício dos pacientes, no caso os que estão entubados.

Em relação a aprender com os erros, a equipe multiprofissional ajuda nisso; por exemplo, às vezes o médico, sem querer, clicou errado e colocou alguma coisa diferente na prescrição, a enfermagem percebe e sempre pergunta antes de administrar os medicamentos, então você 
percebe que errou, aprende com os erros e corrige a prescrição. Mas nunca discutimos essa questão de notificar para alguém o erro que foi percebido pela equipe multiprofissional.

No que diz respeito ao tópico número seis, tivemos aula sobre risco clínico, quando aprendemos sobre drogas ativas. Nos ensinaram que não podem ficar mais do que seis horas em veia periférica, é preciso passar um cateter central mas devemos estar atentos ao risco da passagem do cateter, pois pode fazer um pneumotórax; então, antes de liberar o cateter, é necessário fazer e avaliar o raio $X$. Essas coisas tivemos em aula no internato.

O tópico sete, indicadores de qualidade, foi abordado, mas tudo na prática. No hospital, tivemos uma aula sobre o índice de queda, sobre manter as grades das camas elevadas e outros cuidados, também tivemos aulas sobre os riscos de infecções e seus índices.

Em relação ao envolvimento do paciente e cuidador, tópico oito, eu vi na prática essa interação acontecendo. Quando um paciente, por exemplo, começa a usar insulina, precisamos ensiná-lo como aplicá-la e orientamos que ele pode ir até a UBS mais próxima de casa e pedir para alguém aplicar, assim, o medo vai diminuindo até conseguir se aplicar sozinho. Quando tem cuidador, pedimos para que ele esteja junto nas primeiras vezes para aprender o procedimento. Outro exemplo é quando o paciente sai com colostomia e precisa aprender a trocar a bolsa. Precisamos interagir com o paciente e o cuidador porque, inicialmente, eles têm um pouco de aversão. Acho que essa interação ocorre principalmente nos casos mais críticos, em de paciente com AVC que perdeu a fala, quando temos que interagir mais com o cuidador e ensiná-lo porque quem vai ficar com o paciente depois é ele. Mas acho que tem que ter mesmo, é bom, não tive aula disso não, só vi na prática.

No que se refere à prevenção de infecção, tivemos aula no hospital com os infectologistas sobre os índices, lavagem das mãos e aplicação de precaução de contato: quando o paciente chega de outro serviço ele entra com precaução de contato, só por vigilância. Isso tudo aprendemos no hospital; acho que a primeira aula antes de começar qualquer estágio falava da prevenção de infecção e uso do álcool gel em cada quarto. Além do hospital, na faculdade as aulas de Infectologia abordaram um pouco do assunto. Também me lembro de falarem alguns assuntos em pediatria, por exemplo, sobre quanto tempo a criança que é diagnosticada com coqueluche tem que ficar isolada. Sobre tuberculose, se é um caso que exige internação, tem que ficar isolado a partir do começo do tratamento efetivo por quinze dias. Quando entra em isolamento, colocam uma plaquinha em cima da cama e temos que usar avental e luva só para aquele paciente. Na UTI, cada paciente tem seu estetoscópio, mas quando estamos na enfermaria com o paciente que está em isolamento de contato, usamos o nosso mesmo e o encapamos com luva, depois o limpamos. Na parte da técnica cirúrgica, tem a lavagem da mão também; foi o professor quem deu aula de lavagem das mãos: são cinco a sete minutos lavando a mão, é uma lavagem mais rigorosa do que uma lavagem comum, com escovinha e clorexedine. Tivemos até prova prática de lavagem das mãos e de paramentação cirúrgica. 
Quanto ao tópico dez, não me lembro de ter aula teórica; falamos um pouco na prática sobre assepsia, material estéril, limpar primeiro a área. No hospital particular era mais rigoroso, ouvíamos mais sobre time in e time out, eles falam mesmo. Eu não escutava muito isso no hospital público, quer dizer, deve fazer, mas uma coisa mais informal. No hospital particular, o paciente não saía da maca para a mesa cirúrgica enquanto não fizesse o time in. Em relação à lateralidade, tínhamos que marcar se o paciente ia operar a hérnia direita, por exemplo. Se não fazíamos, o professor ficava bravo, porque ele falava que era obrigação marcar para melhorar a segurança do processo.

O último item, a questão da letra, é importante; tem até legislação falando que o médico não pode escrever de forma que ninguém entenda. Hoje todo lugar tem computador, o que facilitou muito. Essa parte da segurança da medicação, por mais que a gente explique, depende muito da parte cognitiva do paciente, principalmente no SUS, onde tem paciente que não compreende e não fala que não entendeu por vergonha. Acho que falta um pouco de paciência do médico em explicar melhor, pois tem aqueles menos favorecidos ou idosos que não têm acompanhante, que vão sozinhos, que moram sozinhos, daí o tratamento não tem segmento, não resolve.

Como sugestão para abordar esse assunto de segurança do paciente na graduação, acho que a disciplina precisa estar relacionada com a nossa prática porque, assim, guardamos muito mais as informações. Não sei se tivéssemos aula sobre esses assuntos eu me lembraria de tudo na hora da prática. Acho que incluir os pacientes e cuidadores não foi tão discutido, poderia se falar mais; também poderíamos ter mais aulas sobre a segurança nos procedimentos invasivos, apesar de aprendermos na prática. Então, como sugestão, mais aula teórica de segurança nos procedimentos invasivos e na parte da interação com os cuidadores. 



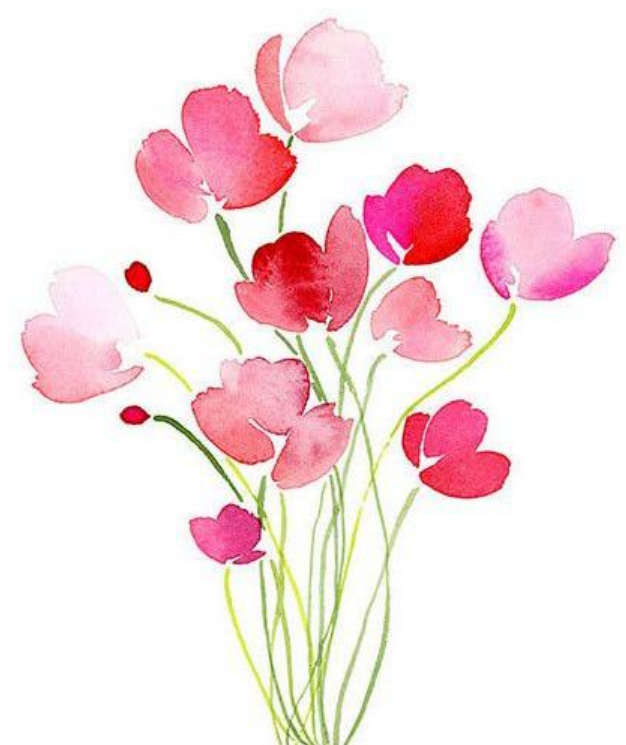

Fa1 - Estudante do $8^{\circ}$ semestre do curso de graduação em farmácia, 20 anos Data: $14 / 09 / 2016$, às $14 \mathrm{~h}$ 

Durante a graduação vimos pouquíssimo sobre segurança do paciente. No sétimo semestre tivemos uma disciplina que abordava a segurança do paciente e do profissional da saúde, com a realização de estudos de casos de diversos âmbitos da área farmacêutica. Foi uma disciplina curta; antes disso, nunca tínhamos visto o assunto. Se algum professor o citou, não chamou a atenção ou ainda não fazia nenhum sentido para nós.

Nos casos que discutimos, aprendemos, por exemplo, que a aplicação de um medicamento anticoncepcional em mulher precisa ser realizada em um lugar mais reservado; numa coleta de sangue, temos que fazer com que o paciente sinta-se confortável e não podemos deixar a sala muito cheia de objetos, pois se o paciente é agressivo, pode tentar pegar alguma coisa e jogar em você...

Sobre os tópicos do manual da OMS, o primeiro assunto, nós tivemos os conceitos básicos nessa disciplina que eu te falei.

No que diz respeito ao segundo tópico, acho que algumas partes foram discutidas nos estudos de casos, mas em poucas discussões o professor falava em erro e troca de medicação.

Em relação ao terceiro tópico, nós vimos um pouco desse assunto em políticas de saúde, no começo da faculdade. Mas não me lembro de relacionar a complexidade do SUS com a segurança do paciente. Agora, no estágio, é que estamos vendo o assunto, pois os pacientes tomam muitos medicamentos e não têm controle do que tomam porque eles passam em médicos diferentes e um não conversa com o outro, nem dão atenção ao medicamento que $o$ paciente já está tomando. O sistema era para ser lindo e maravilhoso, mas acaba não sendo porque não há a comunicação entre os médicos, entre um serviço e outro. Nós temos que nos desdobrar para achar uma forma de fazer com que o paciente tome todos os medicamentos sem que haja interação entre eles.

Quanto ao quarto tópico, o trabalho em equipe é estimulado durante todo o curso, desde o início os professores falam para ser parte de uma equipe, ser líder, tomar decisões e resolver problemas de forma que você possa somar dentro da equipe.

No que se refere ao quinto tópico, notificar incidente ou erros, não aprendemos em nenhuma disciplina e não me lembro de discutirmos o assunto.

Sobre o sexto tópico, entender e gerenciar o risco clínico, nós tivemos em disciplinas com estudos de casos.

A respeito do sétimo tópico, métodos de melhoria de qualidade para aprimorar o cuidado, foi ensinado em Gestão e também em Controle de Qualidade como utilizar os indicadores para monitoramento.

No que diz respeito ao oitavo tópico, foi abordada a interação com o paciente, mas não com o cuidador. A importância de envolver o paciente e como abordá-lo foi discutida em estágio, poucas vezes isso foi falado em sala de aula.

Em relação ao nono tópico, o controle de infecção foi abordado em várias disciplinas, entre elas a Microbiologia; depois falaram sobre a infecção hospitalar e a atuação do 
farmacêutico na indústria, na drogaria. Não foi uma matéria específica, mas várias que abordaram esse assunto.

Sobre o décimo tópico, nós aprendemos sobre a dupla checagem na dispensação e a necessidade de receita dupla para antimicrobianos: em drogaria, temos que carimbar o verso da receita, anotar o CPF do comprador, telefone e outras informações na via que fica na drogaria. Se não tiver duas vias, tiramos cópia para termos esse controle. Tem muita legislação e protocolos para serem seguidos.

No que se refere ao décimo primeiro tópico, o assunto sempre foi discutido, desde o começo do curso, mesmo nas matérias básicas. O professor do estágio é exigente, fala em todo o momento que o farmacêutico precisa conferir tudo. Já aconteceu de pegar um prontuário de paciente com o mesmo nome e quando conferimos a data de nascimento percebemos que estava trocado, o prontuário era de outro.

A letra da receita é outro problema. Vamos nos acostumando, mas quando não conseguimos entender, temos a obrigação de ligar para o médico e falar: não estamos conseguindo identificar essa prescrição do paciente. Caso o farmacêutico não consiga contato com o médico, é registrado o motivo de não ter dispensado. O farmacêutico, pela legislação, é proibido de dispensar qualquer medicamento, fármaco ou substância que esteja em um receituário que ele não consiga identificar. Inclusive, ele pode ser penalizado se dispensar um fármaco que estiver errado. Mas não me lembro de falarmos sobre quando pegarmos uma prescrição errada; é uma boa questão para discutir com o professor do estágio.

Como sugestão, eu acredito que o quinto tópico deveria ser mais abordado para sabermos o que e como notificar.

O controle de infecção também poderia ser mais abordado, não só nas disciplinas teóricas, mas na prática. Poderíamos ter uma disciplina que falasse um pouco mais, pois o que vimos e discutimos eu acho pouco. Talvez uma disciplina optativa ou em ensino a distância [EAD] para quem tiver mais interesse sobre isso. 


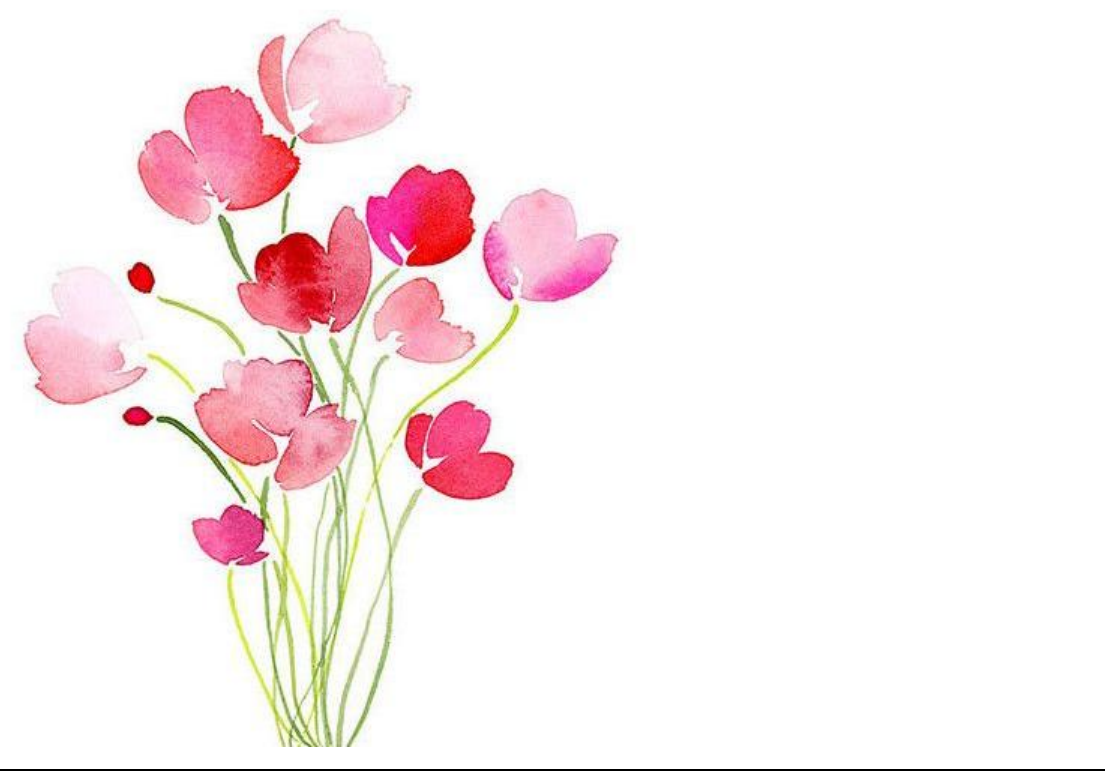

Fa2 - Estudante do 8o semestre do curso de graduação em farmácia, 30 anos Data: 15/09/2016, às $11 \mathrm{~h} 30$ 

O que pude perceber até agora é que temos foco tanto na atenção farmacêutica como na abordagem clínica e o assunto segurança do paciente tem sido falado de forma diluída entre as disciplinas. Nós tivemos uma matéria que abordou a segurança do profissional e do paciente, na qual o professor trazia casos clínicos com exemplos de situações de risco para o profissional e para o paciente em várias áreas de atuação do farmacêutico.

Em relação aos tópicos da OMS, o primeiro foi abordado na disciplina que tivemos no semestre passado, mas também é citado em outras, não de forma direta, mas os professores acabam falando algo sobre isso.

Sobre o segundo tópico, durante a graduação geralmente é falado que você não pode errar porque lidamos com vidas e o erro pode ser crucial para a outra pessoa; acho que essa questão de ser infalível é reforçada e ninguém discute sobre a vulnerabilidade do profissional; esse tema é polêmico não só na faculdade.

No que diz respeito ao terceiro tópico, quando estamos fazendo estágio de atenção farmacêutica discutimos um pouco sobre o paciente ser atendido por vários profissionais que não conversam entre si e nem se preocupam muito com os outros medicamentos que o paciente já toma, então o paciente tem uma variedade enorme de medicamentos e isso impacta na segurança dele. Além disso, nós tivemos uma disciplina que só abordava o SUS, os processos, a complexidade e os níveis de atenção.

Sobre o quarto tópico, os professores de várias disciplinas falam sobre a importância de você estar integrado em uma equipe e auxiliar em todo o processo do tratamento. $O$ enfermeiro tem o seu papel e o farmacêutico pode, por exemplo, auxiliá-lo com informações específicas sobre alguns medicamentos.

No que se refere ao quinto tópico, na faculdade não discutimos isso, porque já é da pessoa ou da vivência profissional dela. Existem legislações que descrevem o que nós podemos ou não fazer e algumas notificações que são obrigatórias, mas notificar um erro humano ou uma falha no processo de trabalho, eu não me lembro de termos discutido.

Em relação ao sexto tópico, é recorrente a discussão sobre risco clínico nas disciplinas clínicas, hoje mesmo a professora estava falando sobre uremia e trouxe vários casos clínicos para estudo para aprendermos sobre o que podemos fazer, por que isso acontece e o que precisamos nos atentar. Esse é o padrão de discussão nas outras disciplinas também.

A respeito do sétimo tópico, eu não me lembro de ter uma disciplina sobre o assunto, mas vimos a parte de controle de qualidade na dispensação dos medicamentos.

O oitavo tópico é pouco abordado, mesmo no estágio de Atenção Farmacêutica nós não discutimos como abordar o paciente para ele entender melhor o tratamento e os medicamentos.

Sobre o nono tópico, esse sim nós tivemos em várias disciplinas. É mencionado desde a pesquisa no laboratório; durante o estágio somos lembrados os dias sobre a higienização das mãos no processo de manipulação dos medicamentos e até na dispensação. 
Em relação ao décimo tópico, a disciplina que discutiu segurança do paciente e do profissional abordou um pouco sobre os protocolos, mas nada em relação aos procedimentos invasivos e não me recordo de outras disciplinas falarem sobre isso.

Quanto ao último tópico, acredito que discutimos bastante, na maioria das disciplinas específicas, a atuação do farmacêutico em todo o processo, conversando com o médico caso precise de alguma sugestão para ajustar os medicamentos necessários e com a equipe que vai aplicar o medicamento. Nas drogarias, a questão da dispensação foi bem abordada. Tem o agravante da letra, às vezes é bem difícil entender o que está escrito e não podemos correr o risco de dispensar um medicamento errado, aí é preciso conversar com o médico.

Como sugestão para a abordagem dos tópicos da OMS durante a graduação, eu acho interessante discutir sobre os fatores humanos influenciarem nos erros que podemos cometer; termos uma outra abordagem sobre os erros, porque hoje em dia só é falado que não podemos errar. Então, quando acontece um erro, nós não sabemos como lidar com a situação e não o notificamos. Isso está relacionado com o outro tópico, notificar os erros para melhorar todo o processo e deixá-lo mais seguro, mas como não podemos errar, se errarmos não será fácil assumir e ainda notificar. Eu acho que uma abordagem mais profunda sobre esse lado humano e os erros que podem acontecer seria interessante.

Outro ponto é sobre a relação com o paciente, como abordá-lo para ter mais envolvimento no tratamento. O assunto poderia ser falado em várias disciplinas com abordagens diferentes. 


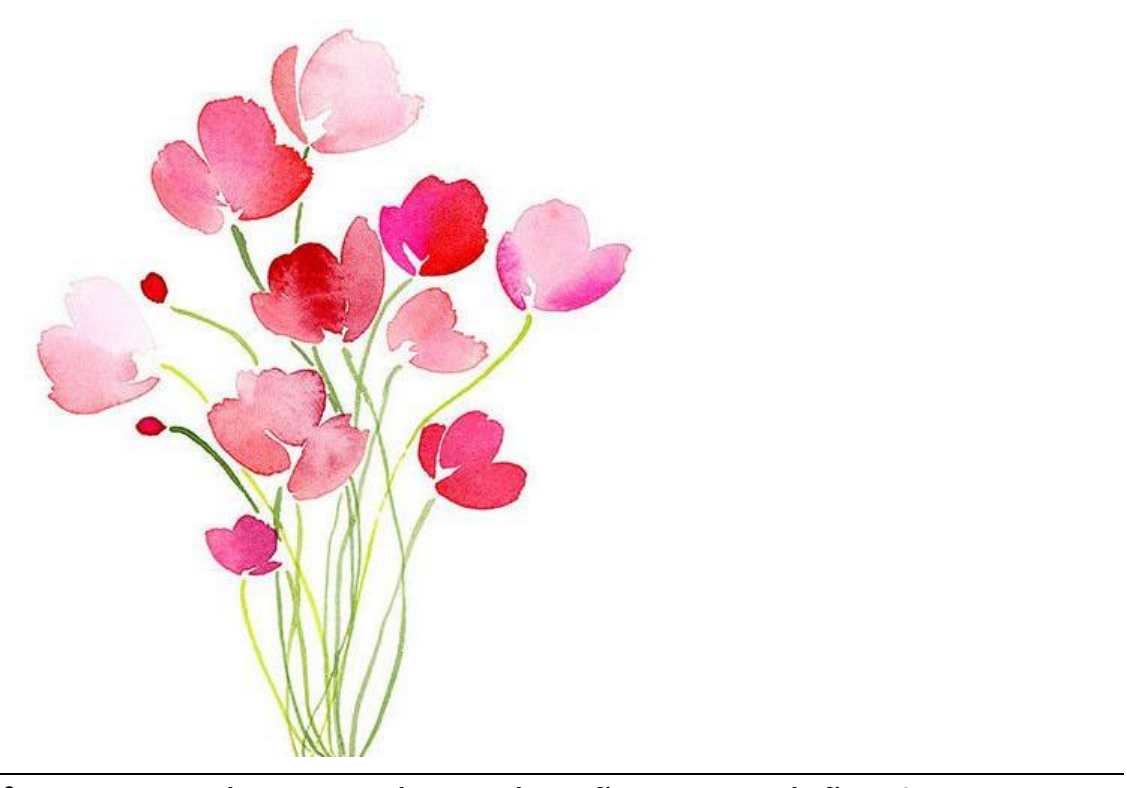

N3 - Estudante do 8 semestre do curso de graduação em nutrição, 45 anos

Data: 20/09/2016, às $12 \mathrm{~h}$ 

A disciplina de Ética, que aborda o que um profissional deva prezar ao trabalhar na área da saúde e que tipo de cuidados e valores deveríamos ter, também poderia abordar esses conceitos de segurança do paciente, mas eu não lembro de ter sido discutido.

No que diz respeito aos tópicos do manual da OMS, o primeiro deles, não me lembro de ter sido abordada essa definição básica.

O segundo tópico também não me recordo de discutirmos.

Sobre o terceiro tópico, nós tivemos uma disciplina na qual a professora falou brevemente sobre o funcionamento de uma UBS, mas não me lembro de ter sido abordado como devem ocorrer os encaminhamentos. Só comecei a entender um pouco o processo quando iniciamos o estágio e recebemos pacientes encaminhados por profissionais externos e internos ao serviço. O prontuário do paciente chega com a triagem admissional realizada pelo enfermeiro, psicólogo e assistente social, mas, de vez em quando, não está completo, faltam doenças que o paciente relata e eu não sei se é porque ele não as relatou ou porque não foi anotado; vamos descobrindo o que o paciente tem na medida em que criamos um vínculo. Eu acho que isso interfere na segurança, pois não temos as informações necessárias no prontuário sobre o motivo do encaminhamento, a história pregressa e a atual do paciente. Algumas evoluções não estão completas e temos que tomar decisões baseadas em informações incompletas ou desatualizadas. Pode ser um detalhe muito importante no tratamento do paciente e que acabamos nos descuidando.

Em relação ao quarto tópico, na disciplina que discutimos políticas públicas, também foi abordada a equipe multidisciplinar, a qual contempla o médico, o enfermeiro, o fisioterapeuta, a nutricionista e outras profissões. Eu vim para o estágio com a expectativa de vivenciar essa prática multiprofissional, mas ficamos muito restritos aos prontuários do nosso próprio setor. Se o paciente passou por outras especialidades, um clínico, por exemplo, não temos acesso, pois o prontuário é fragmentado por área.

No que se refere ao quinto tópico, temos bastante abertura para conversar com a responsável técnica sobre alguns equívocos nos cálculos ou nos parâmetros de referência que encontramos nos prontuários. Conversamos, também, sobre um padrão para a evolução, quais dados devem constar, o que não pode faltar; é interessante ter um padrão para os alunos que passarem por aqui não ficarem perdidos e a informação ficar completa. Então, ao discutirmos esses pontos com a responsável, percebemos que ela está tentando ajustar os processos aqui dentro.

Quanto ao sexto tópico, eu me sinto um pouco insegura, pois eu pensei que discutiríamos mais o assunto no estágio, porque uma coisa é a teoria e outra, a prática, com tantas diversidades de doenças e fatores. Gostaria de poder discutir mais sobre as melhores condutas para determinados pacientes, pois será que o que eu estou prescrevendo pode gerar algum problema para ele? Nós tivemos a abordagem teórica, mas são muitas doenças e 
condições específicas, não dá para falar de tudo, acabamos discutindo as mais graves e como o nutricionista deve atuar para não piorá-la ou como auxiliar para melhorar a condição do paciente.

No que concerne ao sétimo tópico, isso foi mais discutido em nível hospitalar. Por exemplo, se a dieta que você prescreveu para um paciente o ajudou na melhora da taxa nutricional; a adesão do paciente em relação às dietas e a pesquisa de satisfação, com aplicação de um questionário.

A respeito do oitavo tópico, tivemos esse assunto com maior enfoque nos cuidados geriátricos ou com pacientes que não conseguem ter autocuidado e dependem de outra pessoa; falou-se muito sobre os cuidadores para idosos, que eles precisam ter treinamento e conhecimento de algumas coisas.

O nono tópico foi discutido bastante tanto sobre a higienização das mãos, que é fundamental, como o controle de ambiente, controle higiênico-sanitário de alimentos, os cuidados para evitar a contaminação dos alimentos, a higienização dos utensílios e os cuidados com os fornecedores.

Em relação ao décimo tópico, não aboraram a atuação em procedimentos invasivos, pois o nutricionista não realizada nada assim. No uso de protocolos e checklist foi comentado em sala de aula que há uma ficha ou etiqueta contendo a descrição da dieta e a identificação do paciente que deve ser conferida no momento da distribuição. A professora falou dos erros que as copeiras poderiam cometer na entrega das refeições para os pacientes e que era muito importante a nutricionista supervisionar para verificar se realmente estão fazendo a distribuição correta.

Referente ao último tópico, em sala de aula foi abordada a importância de discutirmos, com embasamento científico, com os outros profissionais quando percebemos que a prescrição não está adequada, porque muitas vezes os médicos prescrevem alguma dieta sem conhecimento adequado, por isso devemos participar desse processo, sugerindo qual seria a melhor escolha.

Acho que segurança do paciente poderia ser ensinada em uma disciplina como a Ética e também ser abordada em cada disciplina específica, para ir conscientizando os alunos sobre o assunto.

$\mathrm{Na}$ minha opinião, entender e gerenciar o risco clínico deve ser discutido mais profundamente, eu achei que foi superficial. É claro que depende de cada aluno buscar mais o conhecimento, mas acho importante ser abordado melhor nas aulas. Eu sinto, às vezes, que a formação acadêmica parece estar um pouco distante da realidade. Por exemplo, quando estávamos aprendendo sobre as doenças e os riscos clínicos, se tivéssemos contato com o paciente, vivenciando um caso real, seria muito mais interessante e não esqueceríamos o que aprendemos e, agora, na etapa final da graduação, me sentiria mais apta para lidar com o paciente, com melhor raciocínio dietoterápico. Mas temos toda a teoria e só vamos para a prática no final do curso e por mais que tenhamos estudado, se essa teoria não faz parte da sua rotina, da sua vivência, e se você não a usa, você a esquece! 
A notificação de ocorrências também deveria ser abordada de forma que o erro não fosse visto com uma punição, pois o profissional sentiria segurança em notificar com foco na melhoria, pois muitos profissionais ou alunos por medo pensam: "O que a professora vai pensar de mim? " ou "Eu vou falar que eu errei?" Isso seria um grande benefício para o paciente, pois imagino que, por medo da punição, os erros tornam-se mais graves porque tentam esconder ou omitir certas informações. É preciso entender os motivos que levaram ao erro e isso se relaciona a outro tópico: os fatores humanos. Será que o profissional está bem treinado para a função? Será que está sobrecarregado?

Outra sugestão é sobre a interação e equipe multidisciplinar. Nós aprendemos que isso é importante, mas nunca a vivenciamos plenamente. Alguns campos de estágio proporcionam um pouco mais essa interação, outros nem tanto. Durante os semestres poderiam ser realizados encontro com discussões de casos com os outros cursos. Os alunos de um determinado curso poderiam aprender um pouco com alunos de outros cursos, sobre o modo que aquele outro profissional aborda o mesmo paciente, essa troca de conhecimento seria muito interessante. Todos juntos, com visões profissionais diferentes para o bem do paciente. 



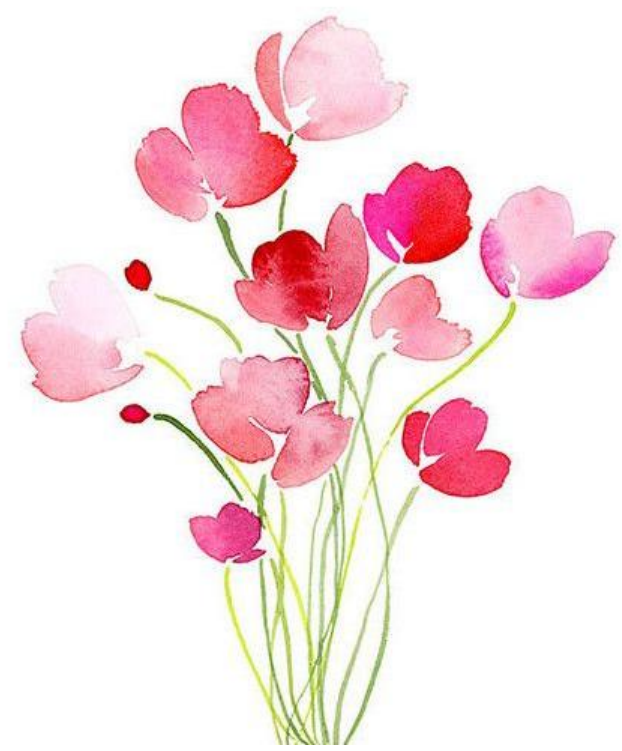

T3 - Estudante do 6o semestre do curso de graduação em terapia ocupacional, 45 anos

Data: 21/09/2016 às $11 \mathrm{~h} 30$ 

Formalmente, como disciplina, eu não me lembro de ter tido algo sobre segurança do paciente. Durante o curso, o assunto surgiu em alguma discussão sobre a prática, porque nós temos uma formação teórica, mas nos preocupamos muito com a prática, e penso que podemos não estar preparados para um eventual problema que surja durante a terapia.

No que diz respeito aos tópicos do guia da OMS, o primeiro conceito não foi abordado, eu não me lembro de ter tido isso em uma disciplina ou feito algum trabalho sobre segurança do paciente. Mas quando estávamos nas aulas práticas, com o paciente no contexto hospitalar, por exemplo, foi abordado como manejá-lo, como transferir esse paciente ou fazer a terapia durante as nossas sessões de forma que ele esteja seguro. Então acredito que alguns aspectos da segurança do paciente tenham sido abordados indiretamente.

Sobre o segundo tópico, acabamos discutindo mais sobreo medo e a insegurança em relação a estarmos ou não preparados para a prática. Às vezes, discutimos com algum professor com quem temos uma relação mais próxima sobre o medo de causar uma lesão ainda maior do que já existe por conta do despreparo. Os professores acabam nos acalmando ao falarem que não estaremos sozinhos, que os outros profissionais poderão nos ajudar.

Quanto ao terceiro tópico, estamos cursando a disciplina Prática em Terapia Ocupacional e Saúde Coletiva que aborda a organização e gestão do SUS e ficou claro o quanto é importante o sistema estar interligado e funcionar; acredito que se na prática o sistema não funcionar, irá interferir muito na segurança do paciente.

Em relação ao quarto tópico, o trabalho em equipe foi muito discutido em vários momentos. Foi falado da importância disso diretamente para o paciente e para nós enquanto profissionais, porque quando compartilhamos, acrescentamos ao todo. Ninguém é dono de um único saber.

No que se refere ao quinto tópico, não foi discutida de forma clara a questão da notificação dos erros, mas é senso comum para mim que quando erramos, pois os incidentes acontecem, conseguimos aprender com o erro e procuramos uma forma para resolvê-lo.

Sobre o sexto tópico, nas disciplinas foram abordadas as avaliações necessárias para primeiro identificar a lesão, por exemplo, depois decidir qual é a melhor indicação da órtese e o motivo da escolha de cada tipo especificamente, o que cada tipo pode auxiliar ou não o paciente. Para as outras terapias também teve esse tipo de discussão.

Referente ao sétimo tópico, algumas disciplinas abordaram o uso dos dados epidemiológicos e seu acompanhamento.

O oitavo tópico foi bem discutido. É muito relevante para a terapia ocupacional ouvir o paciente e o cuidador; faz parte de todo o processo de reabilitação e da recuperação dele. Esse assunto é recorrente e, desde o início da faculdade, é falado sobre a importância de se ouvir o paciente, ouvir o que ele traz e fazer essa interação com a família. Acredito que a terapia ocupacional traz isso como ferramenta para a nossa atuação.

No que diz respeito ao nono tópico, estudamos o assunto em disciplinas básicas e 
específicas. Foi falado tanto da higienização das mãos, como da escolha e higienização do material que utilizamos em algumas atividades.

Em relação ao décimo tópico, utilizamos como instrumentos o histórico com a entrevista e anamnese, os protocolos estabelecidos para avaliação do paciente em cada caso e acompanhamos a evolução do paciente no decorrer das terapias.

No que concerne ao último tópico, apesar de não nos envolvermos muito com os medicamentos, também recebemos as solicitações médicas que podem ter algum equívoco, portanto, precisamos conversar com o paciente ou com a família para entendermos sua necessidade e, se for o caso, fazer contato com o médico para compreendermos a solicitação e definirmos a melhor conduta.

Como sugestão para abordagem desse assunto na graduação, acredito que o quinto tópico seja muito importante, precisamos entender um pouco mais que nós podemos errar e como temos que lidar com isso de uma forma mais segura e profissional. É claro que temos que evitar que os erros aconteçam, por isso precisamos do conhecimento específico de cada área.

Também acho que poderíamos ter o conceito do que é segurança do paciente de uma forma muito clara, tanto na atuação específica da Terapia Ocupacional como a discussão dentro da equipe de saúde.

Sugiro, ainda, que esse conteúdo seja abordado em uma disciplina específica, pois temos como discutir melhor e trazer as dúvidas para o professor, já que nas discussões informais nem sempre daremos a devida atenção ao assunto. 


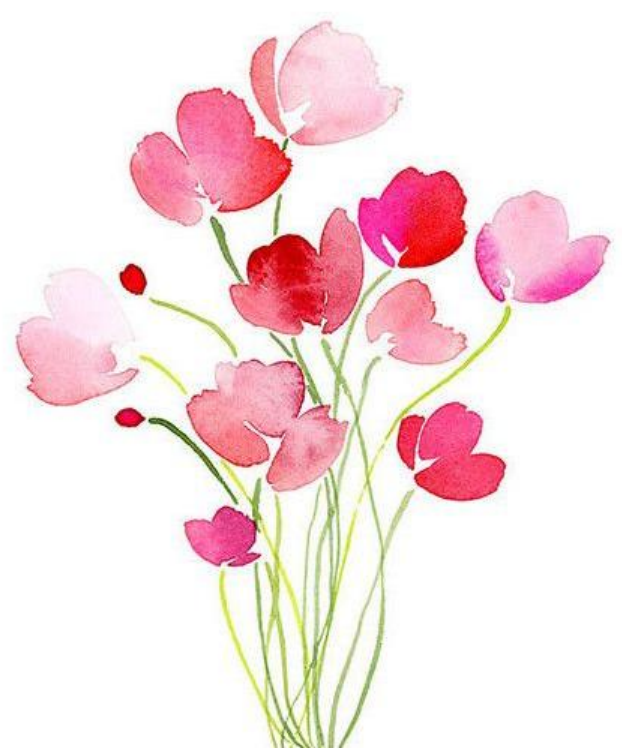

Fa3 - Estudante do 8ํㅗㄹ semestre do curso de graduação em farmácia, 21 anos Data: 22/09/2016, às $11 \mathrm{~h}$ 

No decorrer do curso alguns professores citaram bem superficialmente o assunto, mas nós tivemos uma disciplina de Projeto Integrador que abordou tanto a segurança do profissional quanto a do paciente. Eu acho que foi bem válido, deu para aprender bastante coisa. Tivemos que elaborar dois trabalhos com situações hipotéticas, o professor separava grupos e pedia para pensarmos nas medidas para a segurança tanto do profissional como do paciente. Ele também ensinou algumas diretrizes e resoluções que falavam sobre isso.

No Projeto Integrador cada grupo teve que apresentar trabalhos sobre alguns assuntos, tais como: atendimento ao paciente psiquiátrico em surto e a proteção desse paciente e do profissional que o está atendendo, agressão, intoxicação química, descarte de material biológico e resíduos. Tínhamos que conhecer a diretriz sobre o assunto e como proceder.

Quanto aos tópicos do manual da OMS, estudamos o primeiro deles na disciplina de Projeto Integrador. O professor deu algumas aulas teóricas e pediu para pesquisarmos sobre $o$ assunto.

Em relação ao segundo, o professor falou sobre o erro humano, pois lidamos com pessoas e sempre existe a chance de acontecer alguma coisa, mas temos que nos esforçar ao máximo para isso não acontecer. Também foram discutidas as condições ideais para não ficarmos tão propensos a cometer erros e a importância do treinamento para a habilitação dos profissionais.

O terceiro tópico foi abordado na disciplina Políticas de Saúde. Através de aulas expositivas e discussões aprendemos sobre o impacto que a falta de recursos causa no atendimento dos pacientes, inclusive na segurança.

A respeito do tópico quatro, alguns professores abordaram a necessidade da comunicação e o respeito entre os profissionais de saúde, mas no Projeto Integrador o tema foi mais direcionado para a boa relação entre os profissionais, sempre respeitando a opinião do outro, com foco no bem do paciente. Foi discutido muito sobre o treinamento da equipe e a importância de todos falarem a mesma linguagem com o paciente.

No que se refere ao quinto tópico, nós estudamos sobre a notificação, como funciona e, no nosso caso, tivemos que propor melhorias para evitar que o incidente acontecesse novamente, era um acidente com material pérfuro-cortante. Sobre farmacovigilância, eu sinto falta de ter mais discussão, pois não temos uma matéria específica para isso.

Sobre o sexto tópico, discutimos no Projeto Integrador algumas situações específicas, como o caso do paciente psiquiátrico e os riscos para o profissional e para ele quando está em crise. Também vimos em Farmacologia, ao estudarmos os medicamentos, os riscos e as interações com outras drogas.

Referente aos monitoramentos e aos controles de qualidade biológico e físico-químico, o assunto foi abordado ao avaliar a questão dos medicamentos, da estabilidade e para assegurar a segurança quando da administração de um medicamento. 
Em relação à interação com o paciente e cuidadores, oitavo tópico, foi explicado como orientar o paciente e a melhor maneira de falar com ele. Não temos muito contato com o cuidador, então não foi discutido quase nada a esse respeito; um grupo até abordou a atuação do farmacêutico em home care.

O nono tópico, controle de infecção, foi bastante discutido tanto no Projeto Integrador quanto em outras disciplinas. Na farmácia escola, onde fazemos estágio, tínhamos que lavar as mãos, usar luva e passar álcool na bancada para evitar infecção dos pacientes. Tivemos muita orientação sobre a limpeza das mãos, do local de trabalho e vidrarias. Aprendemos também sobre esterilização no controle de qualidade microbiológica de medicamentos injetáveis.

No que diz respeito ao décimo tópico, o professor falou sobre protocolos em farmácia hospitalar, descarte de resíduos, segurança quando alguma vidraria é quebrada, descarte de agulha, protocolo de prevenção de reações adversas, prevenção de trombose e outros. Em relação aos procedimentos invasivos, nas matérias que falavam da coleta de sangue também foram abordadas as técnicas corretas de punção e a maneira de evitar algum incidente.

Sobre o último tópico, a maioria das disciplinas discute, de uma maneira ou de outra, a segurança no processo de medicação, desde fazer uma anamnese com o paciente, a manipulação do medicamento até a farmacovigilância, que é monitorar o paciente depois que o medicamento foi administrado. Aprendemos todas as fases desse processo. No hospital verificamos se o medicamento prescrito é adequado para doença da pessoa, se a dose está certa e a via de administração. E caso haja algum equívoco, é preciso conversar com o médico, mas depende dele aceitar ou não a sugestão. A dispensação tem dupla checagem, mais de um farmacêutico faz a verificação; a enfermagem também faz esse procedimento, o que evita a ocorrência do erro - mesmo assim, às vezes ocorre. Temos muita atenção em relação à administração; precisamos olhar se a via está certa, se o frasco é correspondente, conferir o rótulo, pois às vezes é uma letrinha ou outra que muda e uma medicação intramuscular pode acabar sendo aplicada via intravenosa, levando o paciente a óbito.

Como sugestão para abordagem desse tema na graduação, eu considero que ficou faltando um pouco mais sobre farmacovigilância. O assunto sobre os fatores humanos e o que influencia as pessoas a cometer falhas também foi abordado de forma superficial e poderia ser mais discutido.

A matéria que abordou segurança, apesar de ser Projeto Integrador, foi bem dinâmica e facilitou a pesquisa e o entendimento sobre o assunto, foi melhor do que apenas aula expositiva, na qual você só ouve, mas não guarda muita coisa. 


\section{B1 - Estudante do $6^{\circ}$ semestre do curso de graduação em biomedicina, 20 anos}

Data: $27 / 09 / 2016$, às $12 \mathrm{~h} 30$ 

Para ser sincera, acho que é escasso o assunto segurança do paciente, talvez porque 0 biomédico, na maioria das áreas, não tem contato direto com o paciente, mas em algumas áreas tem. Acho que o curso foca mais a parte laboratorial. Na disciplina de Ética, a bioética engloba bastante as questões da relação com o paciente, fizemos trabalhos sobre a escolha do paciente, como se deve tratá-lo, mas sempre foi mais abordado o respeito pelo paciente do que a sua segurança.

O assunto também foi um pouco discutido na disciplina de Imagem, por ter um certo contato com o paciente; então foi falado da segurança em relação aos equipamentos, em posicionar o paciente corretamente para manter sua segurança e evitar maiores exposições à radiação, por exemplo.

Quanto ao manual da OMS, em relação ao item número um, não tivemos diretamente em nenhuma disciplina, o assunto nunca foi focado. Indiretamente, os professores de Hematologia e de Imagem comentavam alguma coisa sobre as experiências que tinham passado.

No que diz respeito ao item dois, os professores falaram sobre o impacto de trabalhar muitas horas seguidas, mas não tivemos isso especificamente, foi só um comentário.

Sobre o item três, aprendemos sobre como funciona o SUS, o fluxo do paciente, mas nunca discutimos sobre esse processo e a segurança do paciente.

Quanto ao item quatro, a professora de Hematologia e de Gestão, explicou que todos os profissionais precisam trabalhar juntos para o bem comum.

O item cinco foi bastante discutido, principalmente em relação aos erros que possam impactar no paciente; então a professora explicava e dava alguns exemplos da área laboratorial, como a questão da calibração do equipamento para fazer os exames: se você a fizer só pela manhã e não fizer mais nenhum controle durante o dia, o aparelho pode parar de funcionar no meio da tarde e todos os exames feitos depois disso estarão errados. Por isso é preciso controlar o equipamento pelo menos três vezes ao dia, para evitar erros e futuros danos ao liberar um exame errado. Todo esse controle do equipamento e também o erro, se for identificado, precisa ser registrado.

Em relação ao item seis, em Instrumentação Biomédica I nós aprendemos um pouco sobre os riscos com o foco na segurança do profissional. Em imagem, foi discutido sobre os riscos dos pacientes que precisam receber contraste, quais perguntas fazer para identificar se aquele paciente tem mais risco ou alergia para o uso de contraste ou não.

Quanto ao item sete, tivemos contato mínimo, apenas alguns comentários, mas não como assunto de aula.

Sobre o item oito, não tivemos isso de jeito nenhum, o curso não tem esse foco. Em Imagem o professor até comenta um pouco, mas nada muito importante.

Em relação ao item nove, esse sim nós tivemos com certeza, foi muito falado durante o curso inteiro. As disciplinas Microbiologia e Imunologia abordaram bastante o tema por causa das infecções por vírus. Acho que é um dos itens que eu vi até agora que foi mais explicado. 
No que diz respeito ao item dez, a orientação para procedimento mais invasivo ficou meio perdida entre outros assuntos, acho que cada matéria englobou um pouco, mas é um tema muito importante que precisaria de mais atenção. Nos exames de imagem tem toda a questão do posicionamento, de só liberar o paciente após verificar se a imagem ficou boa e de refazer ou corrigir o exame, caso verifique que há algo errado, antes de liberar o paciente. Agora, sobre confirmar se é direito ou esquerdo, que eu me lembre, não tem protocolo para isso, mas esse tipo de erro é grosseiro e não deveria acontecer. Existem os POPs [Procedimentos Operacionais Padrão] que descrevem os protocolos e o passo a passo de cada exame.

Referente ao item 11, acredito que isso é um problema. Em Farmacologia, a professora até falava que, dependendo da dose, o medicamento pode matar ao invés de tratar. Na nossa realidade o problema é o contraste quando o paciente é alérgico, aí precisa conversar com o médico para verificar as possibilidades. Temos a cultura de que o médico é melhor do que os outros profissionais da saúde; o médico não sabe tudo, como a gente também não, mas provavelmente na nossa área a gente vai saber muita coisa e precisamos saber falar, argumentar o que é correto.

Como sugestão eu acredito que deveria ser mais abordado o contato com o paciente e a família. Mas todos os assuntos são importantes para nos chegarmos à vida profissional mais preparados. Talvez a disciplina de Ética pudesse alterar o nome e envolver assuntos de bioética e de segurança do paciente. O curso é muito voltado para o laboratório e precisamos lembrar que tem biomédico que não vai trabalhar em laboratório.

É interessante focar a discussão sobre esse assunto porque quando você falou em segurança do paciente no começo da entrevista, eu pensei: nunca tive, mas ao conhecer os itens, percebi que alguns pontos foram comentados nas disciplinas, mas é preciso focar nos conceitos que são principais e não só nos comentários e experiências dos professores. 


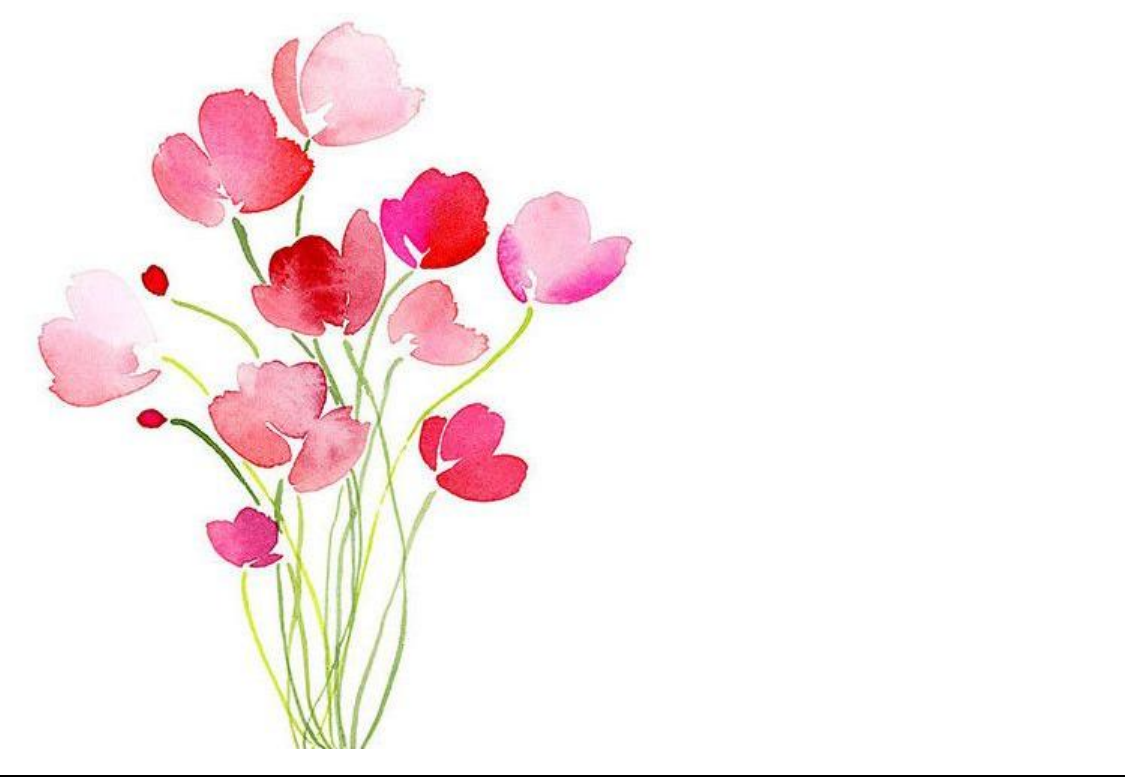

B2 - Estudante do 6ำ semestre do curso de graduação em biomedicina, 21 anos Data: 28/09/2016, às 13:00h 

Nós não temos muito contato com o paciente, só em determinadas áreas, acho que por isso a segurança do paciente não é muito tratada. Por trabalharmos mais no laboratório, nos bastidores, a segurança do laboratório em geral e a segurança do trabalhador são bem abordadas. Em relação ao paciente, discutimos um pouco na disciplina de Imagem e em Hematologia, quando estudamos sobre a coleta de sangue. Gestão também aborda superficialmente o tema, mas acho que será tratado mais no final do curso, perto de ir para o estágio, e é até mais conveniente mesmo. Mas nunca discutimos formalmente o que é segurança do paciente, apenas em comentários dos professores.

Em relação aos tópicos da OMS, o primeiro, sobre o assunto segurança do paciente, eu não me lembro de ter sido mencionado.

No que diz respeito ao segundo tópico, esse sim foi falado. Por exemplo, uma discussão entre profissionais na hora da coleta pode deixar o paciente nervoso e provocar uma vasoconstrição. Em Imagem, discutimos a questão dos equipamentos, a interface entre as máquinas e os sistemas. Não tivemos uma aula sobre as causas de erros, mas quando estávamos no laboratório os professores explicavam que a falta de atenção pode fazer a gente errar um microlitro e, consequentemente, o exame inteiro. Então o tema acabou sendo discutido na aula prática.

Sobre o terceiro item, eu não me lembro de ter discutido nada sobre o assunto.

Referente ao quarto tópico, discutimos sobre a comunicação entre o médico que emite $o$ laudo e o que assina o seu laudo, porque o laudo laboratorial impacta no laudo clínico. Também falamos sobre a comunicação com a equipe da enfermagem na coleta de sangue. Isso é discutido na prática e um pouco na teoria de Gestão, sobre equipe de trabalho, essas coisas.

Relativo ao quinto tópico, a professora explicou a necessidade de notificar os erros, comparar se há diferença de um teste para outro, e analisar o motivo da ocorrência. Isso também em relação ao erro humano, pois a não notificação do erro vai impactar em tudo, principalmente no laudo que vai será emitido para o paciente.

No que se refere ao sexto tópico, a cada procedimento que aprendemos nas disciplinas, fala-se tanto dos riscos quanto dos benefícios. Quando discutimos os contrastes e o risco de alergia, aprendemos as perguntas que devem ser feitas para identificar os riscos.

Sobre o sétimo tópico, os indicadores de qualidade, acho que foi falado superficialmente em outras disciplinas, mas em Gestão isso é bastante abordado.

Em relação ao oitavo tópico, discutimos mais na disciplina de Imagem: o professor explicava como devemos falar com o paciente, que não podemos ser indelicados, que precisamos explicar direito para o ele ou o familiar e que não podemos ser impacientes com a família. Muitas pessoas escolheram biomedicina por não ter o contato direto com o paciente, mas querem atuar na área da saúde.

No que diz respeito ao nono tópico, esse sim foi falado bastante. Na disciplina de Microbiologia, discutimos sobre a contaminação de amostra, obrigatoriedade no uso das luvas 
ser imprescindível, o cuidado no manuseio de equipamentos ...

Referente ao décimo tópico, o professor de Imagem falava muito sobre a importância de se confirmar com o paciente (se ele tiver condições) o lado correto do exame, pois apesar de estar escrito na solicitação, o pedido pode estar errado. Mas não existe um protocolo ou checklist para isso, vai depender do profissional.

No que se refere ao 11ำ tópico, sobre as medicações, o processo todo, nós nunca tivemos. Em Microbiologia, falamos um pouco sobre os antibióticos. Discutimos também sobre a prescrição de contraste para os exames de imagem, pois, dependendo do caso, se o paciente é alérgico, precisamos falar com o médico radiologista do setor.

Como sugestão para abordar o assunto segurança do paciente na graduação eu começaria pelo primeiro tópico, pois eu nem sei o que é isso. Acho contraditório, pois sou estudante da área da saúde, estou trabalhando para o bem do paciente e nem sei o que é mais seguro para ele ou não. Nem o que significa ser seguro ou não, então acho que esse é um tópico muito importante.

Outro assunto é o risco clínico, nem sei se cabe a nós, biomédicos, mas precisamos saber os riscos de cada exame e procedimentos.

Também deveríamos ter mais discussão a respeito dos protocolos de segurança, ter um checklist, principalmente dos exames de imagem, para garantir que seja feito o exame correto.

Eu acredito que a segurança do paciente deveria ser abordada em diversas disciplinas no decorrer do curso, pois cada uma tem um foco e discutiria o assunto de acordo com sua especificidade. Discutimos muito sobre segurança no controle de amostras em laboratório, mas acho que também poderíamos abordar assuntos relativos a outros segmentos nos quais o biomédico pode trabalhar, proporcionando uma visão mais abrangente pois o erro humano está presente em todas as áreas. 


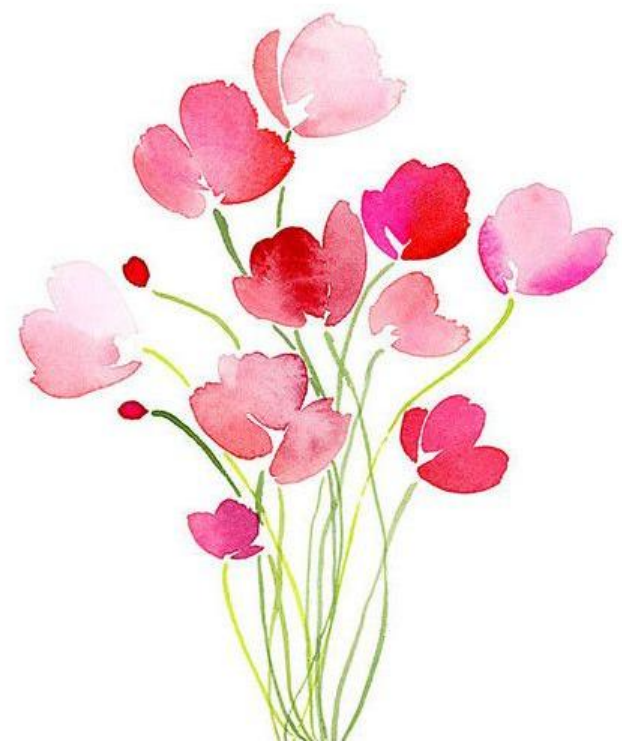

B3 - Estudante do 6 semestre do curso de graduação em biomedicina, 21 anos

Data: 29/09/2016, às $13 \mathrm{~h}$ 

Como a gente, da biomedicina, não tem muito contato com o paciente, eu acho que assunto segurança do paciente fica meio de lado. A gente tem mais a abordagem da proteção de quem está cuidando dos materiais do que do paciente. $O$ único contato que a gente teve mais profundo foi em Imagem, quando o professor falou dos equipamentos de proteção para se usar na hora da radiografia e na ressonância. Em Hematologia, quando realizamos coleta de sangue, a professora nos orientou sobre os cuidados com a seringa, sua manipulação, e como posicionála; fora isso, eu acho que não discutimos muito o assunto. Foram apenas pinceladas.

Referente aos itens da OMS, o primeiro precisa ser abordado de maneira geral, explicando o que é e por que é importante. Eu não sei a definição de segurança do paciente, nas aulas é falado apenas: "isso é importante para a segurança", mas o conceito de segurança do paciente não foi explicado pelas disciplinas.

No que diz respeito aos fatores humanos, o professor de Imagem falou bastante sobre $o$ tema, ele fazia comentários de coisas que já tinham acontecido onde ele trabalhava, da experiência dele. Mas nunca foi abordado como matéria.

Sobre compreender os sistemas e a complexidade no cuidado ao paciente, nós não tivemos, não que eu me lembre. Só diziam assim: "vocês têm que tomar cuidado"; "se der alergia, tem que ter um médico, uma pessoa preparada, um responsável"... Talvez falem alguma coisa na matéria de Gestão que a gente está tendo agora.

A respeito de participar de uma equipe eficaz, a comunicação entre os membros da equipe ou com os pacientes foi pouca discutida. Não tivemos uma disciplina exclusiva, acho que é difícil ter isso, e o assunto não foi tratado formalmente, apenas pontuado em algumas disciplinas, principalmente em Hematologia, na parte de coleta, e de Imagem, pois a gente tem contato com o paciente.

Com relação a aprender com os erros, estamos discutindo em Gestão Laboratorial sobre a notificação dos erros. A professora explicou todos os métodos que podemos utilizar para não incorrer no erro (regras, procedimentos, autodisciplina) e o que fazer para corrigir o erro em si.

Quanto ao item sobre risco clínico, na disciplina de Imagem também foi ensinado como minimizá-lo. O professor falou, por exemplo, de letra legível; que apesar do paciente falar que não tem alergia, ele pode desenvolvê-la e como podemos lidar com isso.

Sobre indicador de qualidade, aprendemos em Gestão, a montagem de gráfico para analisar sensibilidade e reprodutibilidade: quando passar uma amostra num equipamento, para não ter erro, faz a reprodução de uma amostra padrão, que gera um gráfico que permite avaliar o processo.

No que diz respeito à abordagem com o paciente ou com o familiar, a gente não teve. Acho que talvez por não termos muito contato com o paciente. A única coisa falada na disciplina de Imagem, e ainda bem por cima, foi sobre a pessoa que tem claustrofobia precisar de acompanhante na sala de exame. O professor sempre falava que o biomédico tem um problema: só pensa no exame que tem que fazer. Por exemplo, quando chega alguém que precisa fazer 
um exame de crânio, o profissional diz: "chegou o crânio". Não podemos agir assim, pois estamos diante de uma pessoa e devemos ter mais cuidado.

Referente à prevenção e controle de infecção, eu acho que é o que a gente mais aprende. Isso foi falado várias vezes, em praticamente todas as disciplinas, especialmente $o$ cuidado na hora em que pegamos a amostra. Em Imagem, a gente tem uma parte da matéria que é pontual para todos os equipamentos de proteção de quem os está manipulando, mas do paciente mesmo a gente não tem muito, mas do profissional tem bastante.

Esse item sobre segurança do paciente e procedimento invasivo não tivemos porque a gente não faz. Não me lembro de ter sido falado também sobre checklist. Em relação ao uso de protocolo, foi citada a necessidade de conferir o que foi pedido, o professor falou que acontece muito erro por conta da pessoa não conferir ou não prestar atenção na hora de fazer o exame.

A respeito do medicamento, talvez veja em Farmacologia, mas eu estou cursando esta disciplina neste semestre e a gente não entrou em nenhum ponto ainda sobre algum problema com medicação. Em Imagem o professor ensinou sobre as outras opções de contrastes quando o paciente tem alergia. Ele explicou que em alguns exames, caso o paciente tenha alergia, tomar um determinado suco ou água já ajuda como contraste.

Na minha opinião, o que deveria ser falado mais durante a faculdade é o assunto sobre sistemas, porque os professores falam, mais ou menos, de uma rotina laboratorial, mas a gente não vai ficar, necessariamente, num laboratório... Então, acho que seria legal ter alguma coisa, poderia ser até em Gestão. Agora nós temos um trabalho em que temos que montar um laboratório, mas se limita a isso. Sei lá, tem o hospital e mais coisas que daria para conversar.

Essa parte da segurança do paciente, eu acho que poderia ser melhor abordada nos procedimentos, porque temos apenas a segurança do profissional e não do paciente. Mesmo em Imagem que o professor falava sobre isso, mas era só uma pincelada, coisas básicas.

Na questão de medicação não sei... Como a gente não pode prescrever, talvez o que tivemos seja suficiente.

Nessa parte de aprender com os erros para evitar os danos, nós aprendemos como evitar os erros, mas não aprendemos o que fazer depois que o erro ocorreu, como melhorar o processo e corrigi-lo. Se acontecer alguma coisa e acabar a amostra, você não tem mais como fazer a análise, o que fazer? Quais providências teria que tomar? Eu acho que seria importante.

Eu acho que a segurança do paciente não é muito abordada porque são poucas as áreas que o biomédico poderia atuar em contato com o paciente. Então, alguns assuntos também poderiam ser discutidos, como trabalhar em equipe - é claro que trabalhamos em equipe, mas todo mundo fala que o biomédico é o médico sozinho, que fica no microscópio. Acho que é importante falar também da comunicação porque aprendemos bem a parte técnica do microscópio, máquina, passar os dados e só.... Outros tópicos importantes: carga horária e barulho demais, que dificulta a concentração no laboratório para contarmos as hemácias; às vezes está aquela confusão, e eu começo a me perder... 


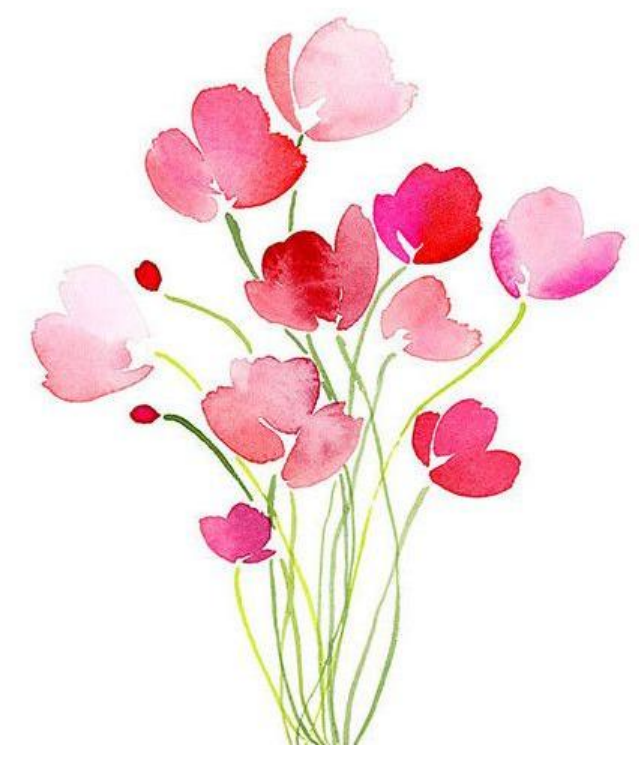

Fi1 - Estudante do $8^{\circ}$ semestre do curso de graduação em fisioterapia, 21 anos Data: 03/10/2016, às $13 \mathrm{~h}$ 

Acredito que como tem se discutido muito mais essa questão da humanização no atendimento à saúde, a segurança do paciente também acaba sendo abordada. Foi falado bastante sobre queda, como na fisioterapia lidamos com os idosos que têm esse risco maior, nós somos bem preparados em relação a isso, que foi abordado em várias disciplinas.

Sobre os tópicos do guia da OMS, o primeiro eu já ouvi falar, mas eu não me lembro de ter sido abordado formalmente em aula, alguns professores compartilharam as suas experiências conosco ou discutiram algum caso no estágio.

Em relação ao segundo tópico, não me recordo de ter discutido algo relacionado a isso.

No que diz respeito ao terceiro tópico, estamos cursando uma disciplina para compreender o SUS, como funcionam todas as esferas de complexidade, mas não fizemos nenhuma discussão a respeito de segurança do paciente no SUS.

O quarto tópico é bastante discutido aqui na faculdade, muitas disciplinas abordam a equipe multidisciplinar; no estágio nós encaminhamos pacientes para outras áreas como a enfermagem, nutrição e farmácia. Além disso, no começo da faculdade tivemos várias disciplinas juntos para nos conhecermos e entendermos um pouco de cada curso, então ficou bem enfatizada a importância do trabalho da equipe multidisciplinar para termos menos erros.

No que se refere ao quinto tópico, nunca falamos sobre os erros, nem sobre notificar os erros. Discutimos entre nós, alunos, algo que não ocorreu da forma que deveria ter ocorrido, mas nem sabia que poderia notificar os erros em uma instituição de saúde.

Concernente ao sexto tópico, quando aprendemos as técnicas e manipulações com o paciente, aprendemos o que não podemos fazer ou em quais situações não podemos fazer determinadas atividades, pois pode prejudicar o paciente, e quais os riscos, mas nunca discutimos o que fazer se acontecesse isso. Eu me sinto despreparada se acontecer alguma coisa algum dia.

O sétimo tópico, nós tivemos algumas disciplinas em que trabalhamos com dados epidemiológicos e alguns indicadores relacionados à fisioterapia, como, por exemplo, queda e extubação acidental.

Sobre o oitavo tópico, nós discutimos a interação com o paciente e o cuidador ou familiar principalmente em relação aos idosos. Mas isso não foi discutido em uma única disciplina, em vários outros momentos os professores falaram sobre o assunto.

Em relação ao nono tópico, a parte da higienização das mãos é bastante falada, mas foi mais focado na área hospitalar e não nas demais áreas de atuação da fisioterapia, como no ambulatório da ortopedia, por exemplo. Acredito que deveria ser mais reforçada a necessidade de higienização das mãos entre um paciente e outro em todas as áreas. Na área hospitalar aprendemos sobre as infecções de vias aéreas e os cuidados que precisamos ter na aspiração traqueal, a colocar as luvas estéreis e manter tudo estéril durante o procedimento.

No que diz respeito ao décimo tópico, precisamos utilizar os protocolos de atendimento de cada especialidade para avaliar o paciente e decidir pela melhor conduta em cada caso. 
Utilizamos técnicas específicas no exame físico e coletamos as informações na entrevista com o paciente ou com o familiar.

No que se refere ao último tópico, como não administramos medicamentos, não discutimos muito sobre isso. Nós verificamos sempre todos os medicamentos que o paciente toma e tentamos associá-los às patologias que ele referiu ter, mas caso tenhamos alguma dúvida, nós a encaminhamos para o farmacêutico ou para algum médico.

Adaptando para a nossa realidade, caso recebamos um paciente com a prescrição de terapia equivocada, após a avaliação da fisioterapia deveríamos ligar para o médico, explicar a avaliação realizada e o tratamento mais adequado.

Como sugestão para abordar a segurança do paciente seguindo esse guia, acho importante o quinto tópico, sobre aprender com os erros e notificá-los não como forma de punição, mas para o aprendizado de toda a equipe.

A questão dos fatores humanos também poderia ser abordada para entendermos as influências do ambiente, da tecnologia e dos sistemas no profissional e na segurança do paciente.

Talvez pudesse ter uma disciplina de Projeto Integrador que tratasse da segurança do paciente, os conceitos básicos importantes para todos os cursos e um pouco de cada um desses tópicos do manual; depois, cada disciplina específica poderia reforçar, durante a graduação, alguns assuntos que se relacionam. 


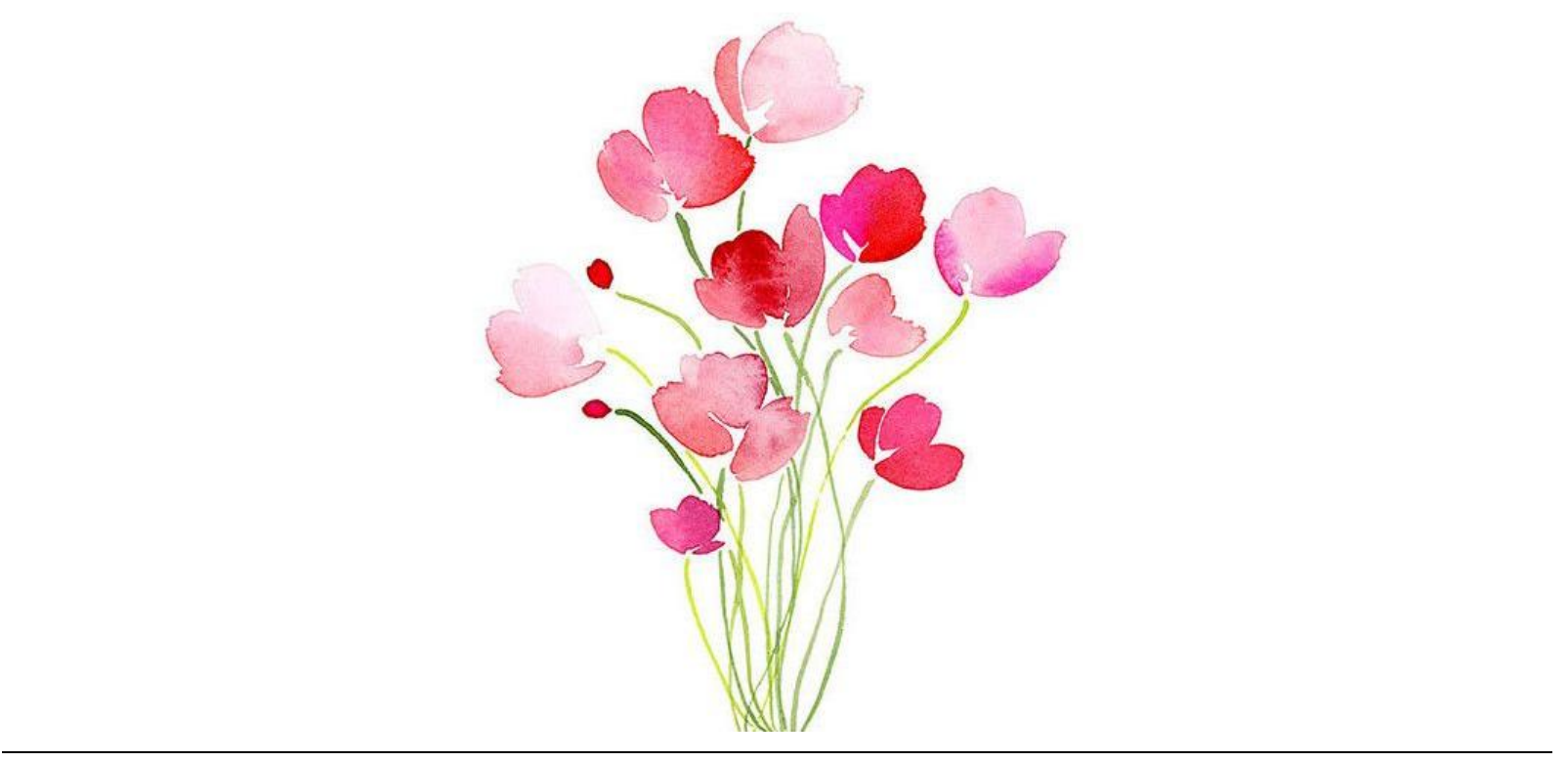

Fi2 - Estudante do 8ํㅗㄹ semestre do curso de graduação em fisioterapia, 30 anos

Data: 05/10/2016, às $11 \mathrm{~h}$ 

A segurança do paciente é abordada em conjunto com as terapias. Por exemplo, quando aprendemos determinada terapia, também são explicados seus riscos para o paciente.

No que diz respeito ao guia da OMS, o primeiro tópico não foi discutido. Talvez eu tenha lido alguma coisa ou ouvido falar, mas não tivemos isso na faculdade.

O segundo tópico também nunca foi abordado.

Sobre o terceiro item, a disciplina de Saúde Coletiva aborda a complexidade do SUS, as referências e os níveis de atuação, mas não os relaciona com a segurança do paciente.

Em relação ao quarto tópico, é discutido o trabalho em equipe multidisciplinar desde o começo e em várias disciplinas. Os profissionais, cada um com seu conhecimento específico, devem trabalhar juntos para oferecer ao paciente um tratamento mais eficaz. Acredito que a segurança seja consequência do trabalho em equipe, mas não chegamos a discutir esse ponto de vista.

No que concerne o quinto tópico, nós nunca discutimos essa questão da notificação de erros.

O sexto tópico foi mais abordado, aprendemos a identificar as circunstâncias que colocam o paciente em risco e o que fazer para reduzi-lo. Por exemplo, nos ensinaram todos os riscos de uma aspiração traqueal e os procedimentos para evita-los. Em relação ao risco de queda, sempre fomos orientados a ter bastante cuidado; também existe o risco na utilização de equipamentos: um paciente com alteração de sensibilidade que precisa fazer tratamento com correte elétrica, se não tomarmos cuidado, podemos queimá-lo.

Referente ao sétimo tópico, não me recordo de ter aprendido algo sobre avaliação da qualidade.

O oitavo tópico foi bastante discutido em várias disciplinas: a importância de interagir, de explicar para o paciente ou falar com a família e com o cuidador.

No que se refere ao nono tópico, tivemos aula teórica e prática sobre higienização das mãos e uso de luva estéril para aspiração traqueal.

O décimo tópico não foi discutido, até porque não fazemos nada invasivo, só aspiração traqueal. Quanto à lateralidade de membros, por exemplo, não tive contato com checklist ou protocolo, mas temos que ler o prontuário antes, avaliar o membro para verificar o que deve ser feito de terapia.

Em relação ao último tópico [melhorar a segurança do processo de medicação], o que podemos fazer é orientar o paciente a procurar outro profissional, um farmacêutico ou um médico, e se tiver algum pedido médico com o qual não concordamos, precisamos conversar com o profissional e explicar a melhor conduta de acordo com a nossa avaliação.

No que diz respeito à sugestão de abordagem da segurança do paciente na graduação, eu acho que todos esses tópicos [do Guia Curricular] deveriam ser abordados em uma disciplina; poderia ser um semestre inteiro discutindo o assunto com os outros cursos, pois no hospital 
vamos trabalhar com a terapeuta ocupacional, com a fonoaudióloga e com a enfermagem e todos precisam aprender sobre isso.

Acredito que a importância da notificação de erros com foco em melhorar e não errar novamente deve ser discutida no quinto tópico; aliás, no sétimo também, para aprendermos sobre a avaliação da qualidade dos hospitais. 


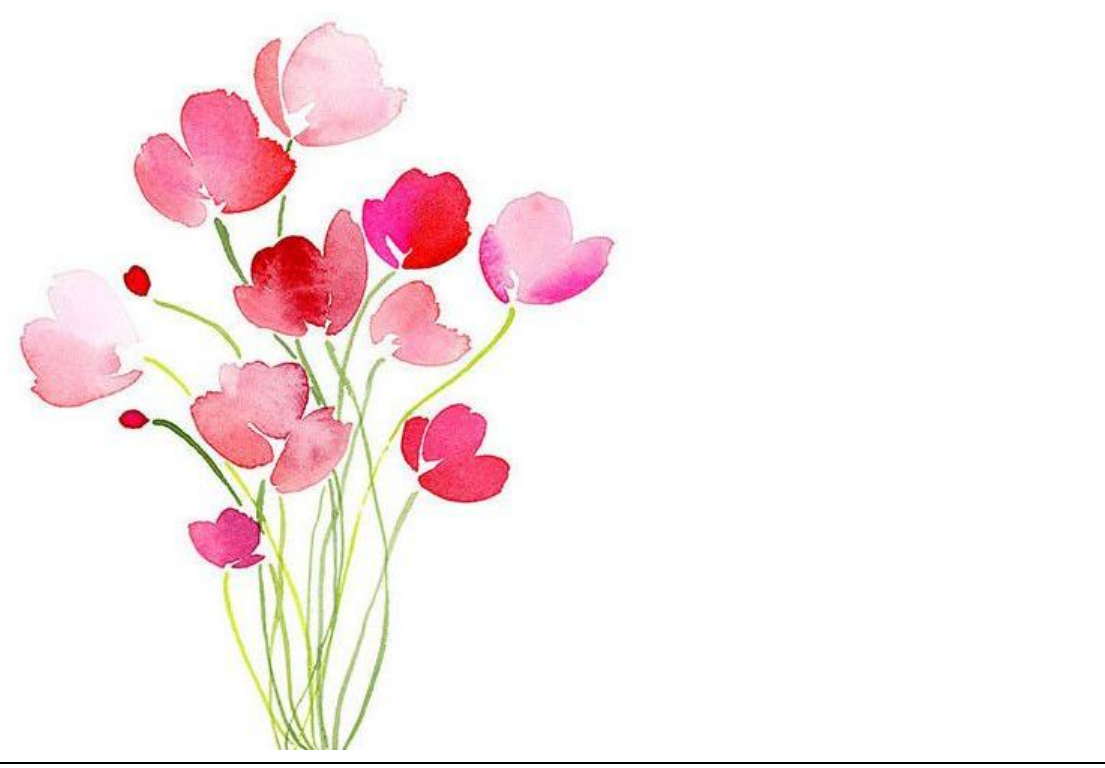

Fi3 - Estudante do 8ํㅗ semestre do curso de graduação em fisioterapia, 22 anos

Data: 05/10/2016, às $13 \mathrm{~h}$ 

O conceito de segurança do paciente não foi abordado diretamente, mas indiretamente. Acredito que esse assunto seja abordado desde o início do curso, principalmente no que diz respeito às quedas de pacientes e aos cuidados com os idosos mais vulneráveis. Como trabalhamos muito com os distúrbios de marcha e paciente em uso de andador, por exemplo, acaba sendo falado bastante sobre os cuidados para evitar queda.

No que diz respeito aos tópicos do guia da OMS, o primeiro, que fala de princípios e definições sobre segurança do paciente, não foi abordado.

Sobre o segundo tópico, também não tivemos discussões sobre o ambiente de trabalho e a segurança do paciente.

O terceiro tópico foi bastante abordado em Saúde Coletiva; tivemos as políticas públicas e agora estamos aprendendo como o SUS funciona, os diferentes serviços, os encaminhamentos para os serviços de referência, mas não relacionamos o funcionamento do sistema com a segurança do paciente.

No que concerne ao quarto tópico, o trabalho em equipe foi bastante discutido, principalmente na área hospitalar, onde teremos muito contato com o médico e demais profissionais dos setores.

Quanto ao quinto tópico, não me recordo de ter sido discutido em algum momento.

Em relação ao sexto tópico, não tenho certeza se o que aprendemos foi gerenciar o risco, pois discutimos sobre uma determinada patologia e o que devemos fazer como terapia; em alguns casos foram explicadas quais as complicações dos procedimentos ou terapias, em outros não. Por exemplo, se o paciente está com edema agudo de pulmão eu tenho que fazer tapotagem, colocar Bipap, mas não foi discutido o risco desse procedimento; já para uma aspiração traqueal, discutimos o que pode acontecer como complicação e o que eu devo fazer. Eu nunca tinha parado para pensar nisso, mas tínhamos que aprender esses riscos para todas as manipulações que fazemos.

No que se refere ao sétimo tópico, discutimos alguns assuntos quando tivemos contato com pacientes com problemas cardiorrespiratórios, pacientes intubados, pacientes graves em UTI e vimos que existe o indicador de extubação e de infecção respiratória nos pacientes com respirador, que são as áreas que a fisioterapia tem alguma relação.

O oitavo tópico foi bastante discutido em várias disciplinas, principalmente em Gerontologia, a importância da boa relação com o paciente e com o cuidador.

No que diz respeito ao nono tópico, os professores foram criteriosos em relação à higienização de materiais, o que deve ser esterilizado, higienização das mãos entre os pacientes e não se esquecer de passar álcool no estetoscópio.

Sobre o décimo tópico, foi discutido principalmente em Ortopedia que temos que ter segurança no procedimento que faremos, precisamos conferir com o paciente o lado, fazer anamnese e exame físico, além de conferir o prontuário.

A respeito do último tópico, não nos envolvemos com o processo de medicamentos; a 
orientação que tivemos é que devemos encaminhar o caso para o farmacêutico ou para o enfermeiro.

Como sugestão para abordagem desse assunto, acredito que poderíamos ter uma disciplina de eixo para todos os alunos da área da saúde, com uma abordagem geral, pois isso é importante para todos nós.

O tópico mais interessante na minha opinião é entender e gerenciar os riscos, pois nós fazemos muitos procedimentos e intervenções, mas precisamos ter clareza dos problemas que podem causar e como evitá-los.

Sobre notificar os erros, também considero importante e necessário, mas acho que as pessoas encobrem os erros que acontecem, pois não se sentem seguras para falar abertamente sobre isso. 
CAPÍTULO 5

CONSTRUÇÃO DAS CATEGORIAS

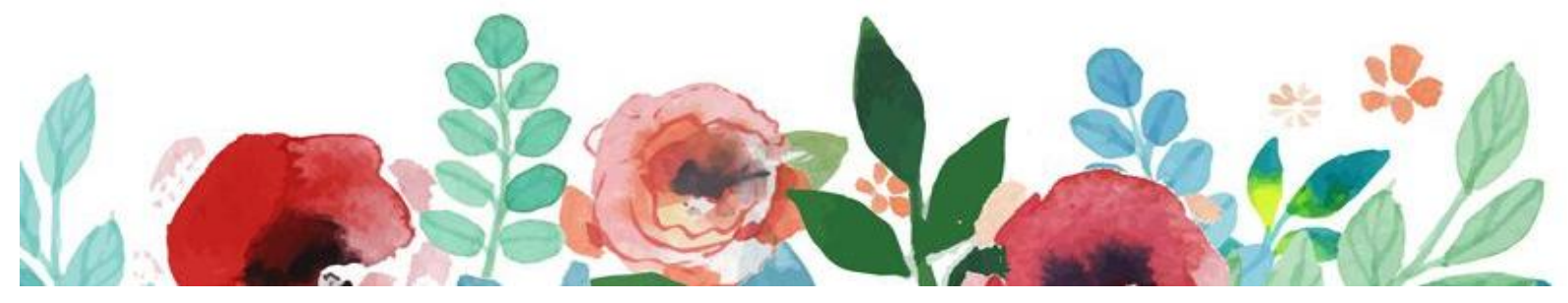



A categorização é uma operação de classificação de elementos constitutivos, agrupados em classes que reúnem elementos característicos comuns, cujo processo se dá por meio do isolamento dos elementos significantes e a classificação deles de forma organizada (Bardin, 2011).

No que concerne à análise de conteúdo, a categorização tem como objetivo fornecer uma representação simplificada dos dados brutos, os quais possibilitarão o aporte de inferências na análise do material (Bardin, 2011).

Para Campos (2004), as categorias são grandes enunciados que abarcam um número variável de temas segundo seu grau de intimidade ou proximidade e exprimem significados que vão ao encontro dos objetivos do estudo, o que possibilita a criação de novos conhecimentos.

O mesmo autor descreve, ainda, que quando a categorização emerge do contexto das narrativas dos participantes da pesquisa, exige do pesquisador um intenso ir e vir ao material analisado, sem perder de vista o atendimento aos objetivos da pesquisa.

A categorização é iniciada pela codificação das unidades significativas que serão posteriormente agrupadas, comparadas e ganharão significado ao longo do processo de análise. Entretanto esta é uma tarefa complexa na pesquisa qualitativa, uma vez que as palavras podem apresentar diferentes significados. Isso exige leituras atentas e completas das narrativas para se obter a visão global do material (Gil, 2009).

Dessa forma, as categorias são conceitos que expressam padrões que emergem dos dados, de acordo com as similaridades que apresentam e são obtidas por meio de um processo intuitivo, porém sistemático, orientado pelos objetivos da pesquisa, pela orientação e conhecimentos do pesquisador (Gil, 2009).

Nesse sentido, Bardin (2011) descreve que realizar a análise temática consiste em descobrir os núcleos de sentido que compõem a comunicação e cuja presença ou frequência de aparição no texto pode significar alguma coisa, considerando o objetivo analítico do fenômeno escolhido.

Este mesmo autor considera a inferência como um importante procedimento para a categorização temática, no qual o pesquisador deve deduzir de maneira lógica algo do conteúdo que está sendo analisado, a partir dos vestígios que se manifestam na superfície das mensagens textuais.

Considerando os pressupostos teóricos para a categorização na análise de 
conteúdo, neste estudo foram elencadas as sete categorias temáticas, a saber:

$\checkmark$ Inserção da temática segurança do paciente durante a formação acadêmica;

$\checkmark$ Falibilidade humana e o aprendizado acerca dos riscos e erros assistenciais;

$\checkmark$ Atuação da equipe de saúde e a inclusão do paciente como parceiro nas tomadas de decisão;

$\checkmark$ Sistemas organizacionais e sua interface com a qualidade assistencial;

$\checkmark$ Protocolos como ferramentas para segurança do paciente;

$\checkmark$ Segurança e qualidade como elementos fundamentais na cadeia medicamentosa;

$\checkmark$ Abordando a temática segurança do paciente: estratégias e metodologias de ensino.

\subsection{INSERÇÃO DA TEMÁTICA SEGURANÇA DO PACIENTE DURANTE A FORMAÇÃO ACADÊMICA}

Nas últimas décadas, a segurança do paciente tem sido frequentemente discutida nas instituições de saúde, bem como inúmeras publicações vêm contribuindo para a sensibilização das questões relacionadas a esse assunto, desafiando os docentes em relação à importância da abordagem dessa temática. Esse desafio vem favorecendo a formação da cultura de segurança durante 0 processo de construção da identidade dos profissionais de saúde, uma vez que o mercado de trabalho espera que, além da formação técnica específica de cada curso, o profissional possua habilidade para a prática colaborativa e atue de forma que a assistência prestada seja qualificada e segura.

Nessa primeira, categoria as narrativas a seguir evidenciam a percepção dos discentes dos setes cursos de graduação pesquisados acerca da abordagem da temática segurança do paciente na sua formação acadêmica.

Leape (2010) recomenda que o ensino da segurança do paciente seja iniciado no primeiro dia da graduação, estendido ao longo do curso e incorporado em todas 
as atividades de ensino. É importante que a educação para a segurança do paciente aborde mais do que apenas conceitos e, assim, contribua para a aquisição de habilidades, atitudes e comportamentos desejados na atuação do futuro profissional.

"Durante a graduação em enfermagem, dá para perceber que o ensino sobre a segurança do paciente ocorre desde quando estávamos no começo da faculdade, pois em diversas disciplinas o assunto foi abordado. [...] A partir do momento que iniciamos os estágios assistenciais, no quinto semestre, esse assunto foi muito mais cobrado, muito mais discutido." (E2)

Corroborando com o exposto a WHO (2011) descreve que a construção do conhecimento sobre segurança do paciente deve ocorrer ao longo da formação dos estudantes na área da saúde, para que desenvolvam habilidades e comportamentos assim que iniciem as atividades nos serviços de saúde.

“Na graduação pouco se fala a respeito da segurança do paciente. O que temos sobre o assunto são abordagens técnicas, por exemplo, a importância da lavagem das mãos e a paramentação adequada, que indiretamente estão ligados à segurança do paciente e a prevenção de infecção. Mas o tema em si, uma discussão ampla a respeito, nunca chegamos a ter." (M1)

"Durante a graduação vimos pouquíssimo sobre segurança do paciente. No sétimo semestre tivemos uma disciplina que abordava a segurança do paciente e do profissional da saúde, com a realização de estudos de casos de diversos âmbitos da área farmacêutica. Foi uma disciplina curta; antes disso, nunca tínhamos visto o assunto. Se algum professor o citou, não chamou a atenção ou ainda não fazia nenhum sentido para nós." (Fa1)

Nas falas dos participantes é possível perceber que não há uniformidade na abordagem da temática segurança do paciente nos diferentes cursos de graduação. O assunto pode estar inserido durante toda a formação e reforçado no momento do curso no qual o aluno inicia a prática clínica; pode estar presente em uma disciplina específica ou aparecer de forma subliminar em conteúdos discutidos nas disciplinas. 
"O conceito de segurança do paciente não foi abordado diretamente, mas indiretamente. Acredito que esse assunto seja abordado desde o início do curso, principalmente no que diz respeito às quedas de pacientes e aos cuidados com os idosos mais vulneráveis. Como trabalhamos muito com os distúrbios de marcha e paciente em uso de andador, por exemplo, acaba sendo falado bastante sobre os cuidados para evitar queda." (Fi3)

No estudo de Melleiro et al. (2017) evidenciou-se o predomínio da abordagem da segurança do paciente nas disciplinas dos semestres em que ocorre a inserção do discente nos cenários de prática assistencial e nos estágios supervisionados obrigatórios no final do curso.

"[...] primeiro tópico da OMS, sobre segurança do paciente, tivemos muita informação sobre as metas internacionais, identificação correta, comunicação efetiva, medicação certa na hora certa e todas as outras foram bem abordadas, principalmente nos estágios, quando fez mais sentido, porque ficou tudo muito mais fresco na nossa mente." (E2)

O ensino sobre segurança do paciente e melhoria da qualidade para os alunos dos cursos da área da saúde é considerado relativamente novo e fundamental para o futuro do cuidado em saúde (Miller, Winterton, Hoffman, 2014).

Assim, para que a segurança do paciente permeie as instituições de saúde, os cursos de formação profissional nessa área desempenham um relevante papel na promoção de habilidades e comportamentos relacionados à segurança do paciente, principalmente, ao demonstrarem a relevância dessa temática durante a formação acadêmica para assistência prestada ao usuário (Yoshikawa et al., 2013; Bogarin et al., 2014).

"[...] a definição do que é segurança do paciente, nunca chegamos a discutir diretamente. A identificação do paciente, eu estou vendo agora no setor de radiologia, onde acompanho a realização dos exames e observo que os profissionais chamam o paciente pelo nome e o conferem na pulseirinha no braço; mas ninguém nunca falou da importância dessa verificação, mesmo nos outros hospitais, isso 
nunca foi discutido, inclusive já cansamos de ver prescrições e receitas trocadas!" (M1)

"No que diz respeito ao Guia da OMS, o primeiro tópico [o que é segurança do paciente?] não foi discutido. Talvez eu tenha lido alguma coisa ou ouvido falar, mas não tivemos isso na faculdade." (Fi2)

É fundamental incorporar essa temática ao longo da formação acadêmica dos profissionais de saúde a fim de que compreendam que tanto a responsabilidade individual como a coletiva contribuem para melhorar e manter a segurança do paciente, possibilitando modificar o panorama atual, no qual as práticas em saúde acumulam riscos e potencializam falhas (Wegner et al., 2016).

No entanto, para que essa temática seja efetivamente inserida no currículo formal e informal dos cursos de graduação, faz-se necessária a sensibilização e a capacitação do corpo docente no que concerne a sua importância na formação dos futuros profissionais, bem como a exigência, por parte das instituições de saúde que irão empregá-los e que desejam a mínima capacitação de seus funcionários, sobre qualidade assistencial e segurança do paciente.

Nessa direção, a WHO (2011), ao publicar o Guia Curricular reconhecia essa necessidade, de modo que parte da publicação está direcionada aos docentes de cursos da área da saúde com o objetivo de desenvolver ou aprimorar os conhecimentos e as habilidades necessárias para implementar a segurança do paciente nas suas disciplinas, visto que requer aprendizagem adicional que extrapola a especialidade de sua formação e atividade docente.

\subsection{FALIBILIDADE HUMANA E O APRENDIZADO ACERCA DOS RISCOS E ERROS ASSISTENCIAIS}

Nesta categoria destacam-se as percepções sobre os fatores humanos que envolvem a atuação dos profissionais de saúde e a abordagem, durante a formação dos alunos, sobre a ocorrência e a notificação de erros assistenciais.

De acordo com a WHO (2011), o estudo dos fatores humanos refere-se à compreensão das limitações humanas e a interface com o ambiente de trabalho e os 
equipamentos utilizados, considerando a variabilidade dos seres humanos ao desempenharem suas atividades profissionais.

"[...] durante a graduação geralmente é falado que você não pode errar porque lidamos com vidas e o erro pode ser crucial para a outra pessoa; acho que essa questão de ser infalível é reforçada e ninguém discute sobre a vulnerabilidade do profissional; esse tema é polêmico não só na faculdade." (Fa2)

"Com relação à aplicação dos fatores humanos, também não foi discutido; pelo contrário, sempre se coloca a culpa na outra pessoa. Por exemplo, se o técnico de radiologia fez o exame do paciente errado ou registrou errado, em nenhum momento paramos para pensar que aquele profissional pode estar com uma gripe ou cansado..." (M1)

A segurança do paciente pode ser influenciada de forma negativa devido à limitação ou à escassez de recursos, sobrecarga de trabalho por insuficiência ou carência de qualificação dos profissionais e múltiplas jornadas de trabalho que potencializam o cansaço e o estresse e contribuem para a ocorrência de erros durante a assistência (Inoue, Matsuda, 2013).

Nesse sentido, é essencial a compreensão, por parte dos profissionais e gestores, de que fatores com a fadiga, o estresse, a falta de comunicação, as interrupções, as habilidade e conhecimentos insuficientes podem contribuir para a predisposição aos erros e eventos adversos (Vicent, 2009; WHO, 2011).

“[...] nós discutimos na graduação a questão de serem pessoas que estão trabalhando e que às vezes não estão muito bem, então não prestam atenção em algo, mas a facilidade do sistema diminui muito o risco, a chance de erro e a necessidade de verificar mais de uma vez aquilo que você está fazendo." (N1)

A engenharia de fatores humanos aplica os conhecimentos sobre os pontos fortes e fracos dos seres humanos para otimizar as interações com o meio ambiente, visando maximizar a produtividade do trabalho e o bem-estar. Quando utilizado na área da saúde, o objetivo é garantir cuidados seguros, eficazes e eficientes, partindo do princípio de que a estrutura molda o comportamento. Assim, os profissionais são 
influenciados pela estrutura de seu ambiente e, mesmo os indivíduos capacitados e bem-intencionados, cometem erros se o sistema não estiver bem adaptado às suas capacidades cognitivas e físicas (Clack, Sax, 2017).

Percebemos nas falas referentes à abordagem dos fatores humanos e sua relação com a segurança do paciente que em alguns cursos parte desse aspecto foi contemplado, entretanto em outros além de não ter sido abordado, o erro por parte do profissional ainda é visto com base na cultura da culpa individual e não com a visão ampliada dos processos e sistemas nos quais o profissional está inserido.

Salientamos que a busca para melhorar a segurança do paciente deve incorporar o desenvolvimento de novas competências dos profissionais de saúde por meio de um currículo acadêmico que incentive a abordagem integrada dessa temática, de forma que tais profissionais estejam confortáveis para identificar e aprender com os erros oriundos dos sistemas e processos de trabalho (VanGeest, Cummins, 2003).

"Referente à questão da notificação, eu vejo que isso é uma grande dificuldade, porque a gente tem a visão de notificar os erros para, justamente, saber onde há falha no processo e melhorar a segurança do paciente, mas as pessoas têm medo de se expor e serem repreendidas. [...] $\mathrm{Na}$ faculdade, tivemos a oportunidade de discutir e entender o sentido real da notificação de ocorrência; descobrir os erros para trabalhar em cima deles e não como punição.” (E1)

"Referente à notificação de incidentes, acho que nunca paramos para discutir sobre isso na graduação. No hospital, por exemplo, se você prescreveu um paciente errado, simplesmente apagava aquela prescrição e colocava outra em cima. Nunca notificamos isso como falha ou pensamos em rever o processo. É assim, bem natural, e os erros acabam até mesmo sendo encobertos. Não discutimos a questão de notificar, de ficar mais atento e resolver as falhas." (M1)

Reason (2000) classificou os erros em deslizes e lapsos, relacionados à falta de atenção e lapsos de memória, respectivamente, e enganos na aplicação das regras ou do conhecimento. Contudo existem circunstâncias que propiciam maior vulnerabilidade dos estudantes e dos profissionais em relação aos erros, entre elas destacam-se: a inexperiência, a falta de tempo, a verificação inadequada dos 
processos e a informação inadequada, além dos fatores humanos como a fadiga e 0 estresse, as interrupções e os ruídos, entre outros.

Segundo a taxonomia adotada pela WHO (2009a), o erro é conceituado como falha na execução de uma ação planejada de acordo com o desejado ou o desenvolvimento incorreto de um plano na fase de planejamento ou de execução.

Para Vicent (2009), os erros podem ser classificados sob várias perspectivas: o comportamento envolvido, os processos psicológicos subjacentes e os fatores que contribuíram para sua ocorrência. Para sua coerente classificação, não pode haver confusão conceitual.

Dessa maneira, é crucial que os discentes tenham uma compreensão básica da natureza e dos diferentes tipos de erros e como eles ocorrem. Assim, poderão planejar estratégias que evitem novos erros ou os interceptem antes de causar danos aos pacientes (WHO, 2011).

Conhecer e modificar o fator contribuinte de um incidente é uma ação importante de prevenção primária. $O$ documento de referência para o PNSP descreve tais fatores como circunstâncias, ações ou influências que desempenham um papel na origem, no desenvolvimento ou no aumento do risco de incidente e os classifica em: humanos, quando estão relacionados ao profissional; sistêmicos, se relacionados ao ambiente de trabalho; externos, quando ligados a fatores fora da governabilidade da instituição, e, por último os relacionados ao paciente, como a não adesão ao tratamento (Brasil, 2014).

"[...] não foi discutida de forma clara a questão da notificação dos erros, mas é senso comum para mim que quando erramos, pois os incidentes acontecem, conseguimos aprender com o erro e procuramos uma forma para resolvê-lo." (T3)

"[...] nunca falamos sobre os erros, nem sobre notificar os erros. Discutimos entre nós, alunos, algo que não ocorreu da forma que deveria ter ocorrido, mas nem sabia que poderia notificar os erros em uma instituição de saúde." (Fi1)

É possível notar nas falas de alguns participantes que não houve discussão a respeito da ocorrência e da notificação dos erros na assistência à saúde e a importância de entendê-los, mitigá-los e aprender com esse processo inerente à condição humana. 
A notificação dos incidentes é um componente fundamental para que uma organização aprenda com os erros. A frequência e a forma como serão analisados dependem da liderança e da cultura da organização. No entanto, as organizações com forte cultura de notificação são mais capazes de aprender com os erros, pois os profissionais que ali atuam sentem-se confortáveis para relatar problemas reais ou potenciais, sem medo de serem repreendidos (WHO, 2011).

Diante da ocorrência de um incidente, o PNSP preconiza a realização da prática educativa, na qual os envolvidos discutem e analisam todos os processos e aprendem juntos. É importante não haver banalização do erro, mas a reflexão dos motivos que levaram ao incidente e quais estratégias serão implantadas para evitar a recorrência (Brasil, 2014).

Tal como a notificação de erros, o gerenciamento de risco nas instituições de saúde é relevante na medida em que é possível identificar situações que expõem os pacientes a riscos e possibilita ações para que tais riscos sejam controlados.

"[...] não tenho certeza se o que aprendemos foi gerenciar o risco, pois discutimos sobre uma determinada patologia e o que devemos fazer como terapia; em alguns casos foram explicadas quais as complicações dos procedimentos ou terapias, em outros não. [...] Eu nunca tinha parado para pensar nisso, mas tínhamos que aprender esses riscos para todas as manipulações que fazemos." (Fi3)

"[...] é discutido um pouco nas aulas práticas, quando a professora ensina alguma técnica, alguma atividade e fala que temos que ter cuidado com determinadas coisas; mas não é assim tão específica para explicar: se fizer isso pode colocar o paciente em risco." (T2)

Quanto mais o aluno compreender as variáveis que estão envolvidas na ocorrência do erro, mais se comprometerá com a notificação e a análise dos incidentes de forma sistêmica como forma de prevenção. Para isso, o currículo deve possibilitar situações de ensino-aprendizagem em que 0 aluno experiencie práticas significativas e, assim, estabeleça atitudes proativas como o auxílio no desenvolvimento de estratégias para identificação e controle dos riscos (Cauduro et al., 2017). 
"[...] eu me sinto um pouco insegura, pois eu pensei que discutiríamos mais o assunto no estágio, porque uma coisa é a teoria e outra, a prática, com tantas diversidades de doenças e fatores. Gostaria de poder discutir mais sobre as melhores condutas para determinados pacientes, pois será que o que eu estou prescrevendo pode gerar algum problema para ele? Nós tivemos a abordagem teórica, mas são muitas doenças e condições específicas, não dá para falar de tudo, acabamos discutindo as mais graves e como o nutricionista deve atuar para não piorá-la ou como auxiliar para melhorar a condição do paciente." (N3)

O gerenciamento de riscos clínicos permite a identificação de potenciais erros e, embora seja impossível erradicar todo o risco, muitas ações podem ser introduzidas para minimizar oportunidades de erro. A abordagem sobre 0 gerenciamento do risco clínico é relevante para os alunos, pois os instrumentaliza para reconhecer que tanto o cuidado quanto o tratamento clínico possuem riscos que podem gerar incidentes. Assim, deve-se ponderar o tempo todo sobre os riscos e os benefícios de cada situação clínica, bem como o reconhecimento das limitações e da falta de experiência do profissional e a necessidade de evitar-se qualquer cuidado ou tratamento não supervisionado (WHO, 2011).

A National Patient Safety Agency (NPSA) define gestão de riscos como avaliação, análise e gerenciamento dos riscos potenciais. Considera que com este método é possível conhecer as circunstâncias ou perigos que podem levar a um futuro dano, minimizar a probabilidade e a frequência de ocorrência e suas consequências ou gravidade (NPSA, 2004).

Inúmeros fatores contribuem para a ocorrência de incidentes relacionados à assistência nas complexas instituições de saúde. Contudo faz-se necessária a identificação e o tratamento dos riscos aos quais os pacientes estão submetidos, tal como objetiva o PNSP e determina a RDC ํo 36 de 2013 publicada pela ANVISA, que estabelece como responsabilidade do Núcleo de Segurança do Paciente (NSP) a identificação, análise, avaliação, monitoramento, tratamento e comunicação de riscos (Brasil, 2013b; Brasil, 2013c). 


\subsection{ATUAÇÃO DA EQUIPE DE SAÚDE E A INCLUSÃO DO PACIENTE COMO PARCEIRO NAS TOMADAS DE DECISÃO}

O trabalho em equipe está frequentemente sedimentado no discurso dos profissionais de saúde, entretanto, na prática assistencial percebe-se pouco engajamento real dos diversos profissionais com um objetivo comum, que articule e congregue os saberes específicos de cada profissional.

Dessa forma, esta categoria aborda a percepção dos alunos no que diz respeito ao trabalho dos diferentes profissionais na equipe de saúde, assim como 0 envolvimento do paciente na assistência prestada.

"O trabalho em equipe também foi discutido. Hoje, por causa da internet, o paciente sabe do tratamento antes mesmo de começá-lo. Por isso a importância da gente conversar, de falar a mesma linguagem, senão o paciente vai questionar. [...] Ter uma visão multidisciplinar também foi bem trabalhada conosco." (E1)

De acordo com Peduzzi, Leonello e Ciampone (2016), o trabalho em equipe consiste em uma modalidade de trabalho coletivo que se configura na relação recíproca entre as múltiplas intervenções técnicas e a interação dos agentes de diferentes áreas profissionais, por meio das conexões existentes entre as diferentes atividades executadas.

Para a WHO (2011), o trabalho em equipe envolve mais do que a identificação com o grupo composto de pessoas da sua própria profissão. Uma equipe eficaz é aquela cujos integrantes, incluindo o paciente, comunicam-se entre si, conciliam suas observações, competências e responsabilidades pela tomada de decisão com o objetivo de otimizar a assistência prestada ao paciente. Assim, é importante que os alunos conheçam os benefícios de equipes multidisciplinares e como podem ser eficientes na melhora dos cuidados e na redução de erros.

"No que se refere ao [...] trabalho em equipe, temos bastante discussão sobre o tema, principalmente no internato. Antes disso, no primeiro ou segundo ano, a questão da equipe multidisciplinar é abordada, mas não temos muita dimensão de qual é o nosso papel naquele momento; entendemos o conceito, porém ainda não 
fazemos parte de nenhuma equipe. Agora, no internato, ao participarmos de uma equipe, conseguimos avaliar os prejuízos dos serviços onde isso não acontece. Nós percebemos a importância do trabalho em equipe na conduta do médico da UTI ao ouvir a fisioterapeuta e a enfermeira, assim como a enfermeira vai ouvir os outros, vai discutir com a equipe multidisciplinar algum caso." (M2)

"[...] a importância da equipe multidisciplinar, foi discutido em vários semestres. É importante que ocorram as reuniões de equipe para discutir como cada profissional pode colaborar no cuidado do paciente[...]." (T1)

A prática colaborativa é efetiva quando há oportunidades para a tomada de decisão compartilhada e reuniões de equipe de rotina que possibilitem aos profissionais de saúde decidir sobre metas comuns e planos de gerenciamento de pacientes, balancear tarefas individuais e compartilhadas e negociar recursos compartilhados (WHO, 2010).

[...] muitas disciplinas abordam a equipe multidisciplinar; no estágio nós encaminhamos pacientes para outras áreas como a enfermagem, nutrição $e$ farmácia. Além disso, no começo da faculdade tivemos várias disciplinas juntos para nos conhecermos e entendermos um pouco de cada curso, então ficou bem enfatizada a importância do trabalho da equipe multidisciplinar para termos menos erros." (Fi1)

Para Santos et al. (2010), os cuidados em saúde exigem que profissionais de diferentes especialidades atuem conjuntamente em micro sistemas, como enfermarias, unidades ou departamentos. Portanto, o trabalho em equipe é considerado um fator humano fundamental para a qualidade e a segurança do cuidado prestado nas instituições de saúde.

Em saúde, o trabalho em equipe é complexo e considerado impulsionador de transformações; a comunicação efetiva é ponto chave para o sucesso. Sua prática pode ser aprimorada por meio de simulações, programas de treinamentos para habilidades de comunicação e maneiras padronizadas de apresentar informações do paciente. Tais ações constituem formas efetivas de transpor barreiras à comunicação ineficaz e contribuem para o cuidado seguro e desfechos favoráveis (Nogueira, Rodrigues, 2015). 
Nessa perspectiva, a comunicação entre os membros da equipe é fundamental no sentido de fomentar a partilha de um mesmo objetivo, independente dos papéis e funções individuais. Todavia, a comunicação pode ser dificultada pela hierarquia resultante de uma cultura profissional e institucional que acarreta dificuldade de alguns grupos profissionais em se expressar abertamente com outras classes profissionais (Santos et al., 2010).

Reeves (2016) destacou que diversos estudos apontam que a educação interprofissional resulta em mudanças positivas no conhecimento e na habilidade do aluno para a comunicação e o trabalho colaborativo. Esse novo comportamento é usualmente relacionado ao maior entendimento dos papéis e responsabilidades de cada profissional na equipe; e o desenvolvimento dessas competências colaborativas pode afetar positivamente a atenção ao paciente.

"Sobre a interação com os pacientes e cuidadores, discutimos mais nos extremos de idade, as crianças e os idosos, pois geralmente você inclui mais a família na discussão. O paciente adulto, em idade ativa, é mais complicado, nem todos os profissionais que acompanhamos sentam com o paciente, conversam e o incluem nesse processo de cuidado[...]." (M1)

"[...] foi muito discutido em várias disciplinas, envolver e ensinar o paciente, o familiar ou cuidador no tratamento é fundamental para o sucesso e a melhora do paciente nas atividades." (T2)

Em 2006, na Aliança Mundial para a Segurança do Paciente, a WHO enfatizou a importância da comunicação com o paciente ao destacar que as instituições de saúde com melhores resultados em relação à segurança do paciente incentivavam a estreita participação do paciente e seus familiares nos processos de tomada de decisão durante o tratamento desenvolvido (WHO, 2006).

"Sobre a interação com pacientes e cuidadores, o assunto é abordado de forma geral, não em uma disciplina específica, mas sempre está nas discussões de todas as matérias, porque isso é muito importante [...]." (E3) 
O cuidado centrado no paciente com o qual se desenvolve a comunicação eficaz constitui um dos passos fundamentais na diminuição da probabilidade de risco, resultando no aumento da segurança e na sua satisfação, fatores determinantes para o envolvimento ativo nos processos assistenciais (Santos et al., 2010).

De acordo com a WHO (2011), os alunos devem ser apresentados ao conceito de que a equipe de saúde inclui também os pacientes e/ou seus cuidadores, e que estes desempenham um papel fundamental na garantia de assistência segura. O sistema de saúde não utiliza adequadamente as competências dos pacientes, como o conhecimento de seus sintomas, dores, preferências e sua postura em relação ao risco. Se orientados e engajados no seu próprio cuidado, podem ser um segundo par de olhos caso algo inesperado aconteça.

Para que o cuidado centrado no paciente ocorra, é preciso que os profissionais desenvolvam empatia, compaixão e capacidade de responder às necessidades, valores e preferências expressas pelo paciente ou familiar, além da transparência na assistência e condutas. Portanto, é indispensável uma discussão mais aprofundada desse aspecto na formação dos profissionais de saúde, de modo que possa ser, efetivamente, refletido na prática (Brasil, 2013a; Langer et al., 2016).

A ANVISA disponibilizou recentemente uma publicação destinada aos pacientes, familiares e acompanhantes com orientações de como participar dos processos assistenciais para melhorar a segurança do paciente, pois quando é ouvido e convidado a participar ativamente de seu cuidado e tratamento, deixa de ser um mero recebedor passivo de cuidados e pode contribuir com um atendimento mais seguro em parceria com os profissionais de saúde (Brasil, 2017c).

\subsection{SISTEMAS ORGANIZACIONAIS E SUA INTERFACE COM A QUALIDADE ASSISTENCIAL}

Esta categoria apresenta a percepção dos alunos no que concerne à complexidade do sistema de saúde que integra desde a menor unidade onde ocorre a assistência à saúde até as organizações, departamentos e serviços, bem como o uso das ferramentas da qualidade para avaliação dos processos mensuráveis do sistema de atenção à saúde. 
A prestação de cuidados em saúde é considerada integrante de um sistema complexo, pois há inúmeras partes interagindo simultaneamente, o que dificulta prever o comportamento e o resultado do sistema como um todo (WHO, 2011).

A complexidade do sistema de saúde está relacionada, entre outros aspectos, com a diversidade das fontes de informação e diferentes interfaces entre os profissionais de saúde, as equipes e setores, o paciente, a tecnologia e a necessidade de atuação em diferentes ambientes (Brasil, 2013a).

"Sobre a complexidade do sistema de saúde, tivemos a organização do SUS [Sistema Único de Saúde], referência e contra referência; a UBS como entrada no sistema que encaminha o paciente para o ambulatório de especialidades que, se achar necessário, o encaminhará para o serviço hospitalar; depois, o paciente retorna para o serviço de origem. Tivemos esta parte burocrática e técnica, mas nunca discutimos sobre pensar no paciente que passará por todo esse trâmite, só percebemos que ele se perde e, às vezes, não retorna de maneira adequada." (M1)

Conhecer o sistema de saúde pode contribuir para a compreensão de como a estrutura organizacional e os processos de trabalho colaboram para a qualidade global do cuidado ao paciente nas diversas esferas de atuação, todas as suas complexidades e interdependências, permitindo a análise dos fatores organizacionais responsáveis pelo mau funcionamento dos serviços e por erros (WHO, 2011).

“[...] na disciplina de Saúde Pública, foi explicado como nosso sistema está estruturado, mas não relacionamos isso com a segurança do paciente, apenas aprendemos como o SUS funciona." (T2)

Os erros na assistência à saúde não são raros e devem ser entendidos como resultados da complexidade dos sistemas que ainda desconsideram a falibilidade intrínseca ao processo cognitivo humano. Esforços devem ser investidos para mudar a cultura, da punição para a segurança, na qual o erro é considerado sob a perspectiva de falhas do sistema; falhas que devem ser amplamente analisadas, corrigidas e prevenidas (Pedreira, 2009). 
"[...] nós vimos um pouco desse assunto em políticas de saúde, no começo da faculdade. Mas não me lembro de relacionar a complexidade do SUS com a segurança do paciente. Agora, no estágio, é que estamos vendo o assunto, pois os pacientes tomam muitos medicamentos e não têm controle do que tomam porque eles passam em médicos diferentes e um não conversa com o outro, nem dão atenção ao medicamento que o paciente já está tomando. O sistema era para ser lindo e maravilhoso, mas acaba não sendo porque não há a comunicação entre os médicos, entre um serviço e outro. Nós temos que nos desdobrar para achar uma forma de fazer com que o paciente tome todos os medicamentos sem que haja interação entre eles." (Fa1)

Os pacientes também estão inseridos no complexo sistema de saúde e quando não se atenta ao contexto socioeconômico e cultural em que estão inseridos, a assistência pode ocorrer abaixo do ideal. A falta de comunicação clara entre os diversos profissionais de saúde entre si e com os pacientes, além de contribuir com o baixo envolvimento nas decisões do seu tratamento, influencia na fraca adesão ou nas interrupções das terapêuticas e cuidados necessários.

A abordagem sistêmica do cuidado à saúde auxilia na compreensão e análise dos múltiplos fatores subjacentes aos eventos adversos. Contudo, se os resultados da assistência ao paciente não são mensurados, é difícil saber se as ações tomadas para resolver um problema realmente foram eficientes (WHO, 2011).

Wachter (2013) descreve que a segurança do paciente é considerada um subconjunto da qualidade assistencial, porém é mais difícil de ser mensurada porque a identificação de incidentes depende, muitas vezes, da sensibilização e da notificação individual do profissional de saúde.

"[...] métodos de melhoria de qualidade para aprimorar o cuidado, foi ensinado em Gestão e também em Controle de Qualidade como utilizar os indicadores para monitoramento." (Fa1)

"A utilização de métodos de melhoria da qualidade para aprimorar o cuidado foi citada em diversas disciplinas, com mais foco em Gestão. Foi discutido sobre 
usar dados para saber se o processo está sendo realizado adequadamente ou não e, se não estiver adequado, quais os caminhos para melhorá-lo.” (E3)

O uso de métricas padronizadas é fundamental para promover melhorias porque estabelece um objetivo compartilhado entre os profissionais e confirma se as ações implantadas para a mitigação das falhas estão surtindo o efeito esperado (NPSF, 2015).

"[...] foi abordado um pouco em sala de aula; no estágio aprendemos sobre o indicador de satisfação, um dos maiores da nutrição.” (N1)

“[...] não me lembro de aprendermos sobre qualidade do cuidado." (T2)

É possível observar que os conceitos relacionados à qualidade e suas ferramentas foram abordados em alguns cursos; em outros, o aluno não teve contato com tal temática.

As ferramentas da qualidade possuem diversos objetivos, dentre eles destacam-se o mapeamento dos processos para a prevenção da ocorrência de falhas, o detalhamento e a descrição de etapas dos processos assistenciais, a análise das causas subjacentes de um evento adverso e seus efeitos, 0 direcionamento das ações em decorrência da priorização dos problemas mais incidentes, além do acompanhamento temporal dos processos mensurados, entre outros (Rodrigues et al., 2011).

De acordo com a WHO (2011), há fortes evidências que os cuidados aos pacientes melhoram e os erros são minimizados quando os profissionais utilizam métodos e ferramentas da qualidade. Portanto, quanto mais precoce for a abordagem desses aspectos com os alunos, maior será a incorporação e a aplicabilidade dos conceitos na prática profissional. 


\subsection{PROTOCOLOS COMO FERRAMENTAS PARA SEGURANÇA DO PACIENTE}

A quinta categoria versa sobre a percepção dos alunos em relação às ações empregadas para o controle de infecções, protocolos assistenciais e o uso de listas de verificação nas diferentes áreas de atuação dos profissionais nas instituições de saúde.

Protocolo é definido como o resultado do consenso técnico-científico baseado em evidências e tem como objetivo auxiliar os profissionais nas decisões frente a uma situação clínica específica. Sua implementação está relacionada à melhoria do cuidado por garantir que as melhores práticas estão sendo aplicadas na assistência à saúde e por minimizar a variabilidade de condutas entre os profissionais (Brauer, Dias, 2014).

Diante da complexidade da assistência à saúde e as peculiaridades de cada ser humano assistido, precisamos estabelecer algumas regras baseadas em evidências científicas, as quais possibilitem aos membros da equipe de saúde informações e apoio sobre decisões, ações e resultados do cuidado prestado a partir de metas pré-estabelecidas (Sartori, Yamanaka, 2014).

Para a WHO (2011), métodos efetivos para melhorar a qualidade da assistência e segurança do paciente incluem a implementação de protocolo, caracterizado por um conjunto de passos essenciais que devem ser seguidos em uma ordem específica; diretrizes, que são recomendações para determinadas situações específicas; e o checklist, cujo objetivo é garantir que itens obrigatórios não sejam esquecidos.

"[...] no começo da faculdade discutimos um pouco o uso de protocolos em uma disciplina de eixo chamada Cuidados em Saúde. Aprendemos os protocolos gerais, inclusive higienizar as mãos e os materiais que usamos, e também que cada instituição tem protocolos que devemos seguir." (T2)

"A prevenção das infecções foi bastante abordada desde o princípio, em todos os momentos e em todas as matérias. A gente estava estudando Genética e já estavam falando da higienização das mãos. Discutimos também o assunto na 
matéria Prevenção de Infecção Hospitalar, onde aprendemos sobre controles específicos em Centro Cirúrgico; mas, no geral, todos os professores comentaram o tema." (E1)

O protocolo de higiene das mãos em serviços de saúde, publicado por meio da Portaria do Ministério da Saúde no 1.377, de 9 de julho de 2013, tem por finalidade instituir e promover a higiene das mãos nos serviços de saúde do país com o intuito de prevenir e controlar as infecções relacionadas à assistência à saúde (IRAS), visando à segurança do paciente, dos profissionais de saúde e de todos aqueles envolvidos nos cuidados aos pacientes e deve ser aplicado em todos os serviços de saúde, públicos ou privados, que prestam cuidados à saúde, seja qual for o nível de complexidade. Nessa mesma Portaria foram também publicados os protocolos de cirurgia segura e úlcera por pressão (Brasil, 2013d).

Em contrapartida, os protocolos de Prevenção de Quedas, Identificação do Paciente e Segurança na Prescrição, Uso e Administração de Medicamentos, foram publicados na Portaria do Ministério da Saúde no 2.095, de 24 de setembro de 2013 e também devem ser implementados em todas as instituições de saúde do país (Brasil, 2013e).

O primeiro desafio global para a segurança do paciente proposto pela Aliança Mundial para a Segurança do Paciente em 2005 e denominado "Cuidado limpo é cuidado mais seguro" teve como um dos objetivos o aprimoramento das práticas de higiene das mãos, visando à prevenção de infecções (WHO, 2009b).

Nas falas dos participantes, é possível perceber que, durante a graduação, houve a abordagem da higiene das mãos nos diferentes cursos. Há de se refletir se nas atividades de estágio, que ocorrem nas diversas esferas da assistência à saúde, existe infraestrutura adequada para a prática recomendada e ensinada sobre a higiene das mãos, a fim de introjetar essa prática nos futuros profissionais da saúde, uma vez que se trata de uma importante intervenção individual para a prevenção e redução das IRAS.

“[...] aprendemos na faculdade e também nos estágios sobre o controle de infecção. Em todos os andares do hospital esse controle existe; se você vai falar com o paciente, precisa verificar se tem alguma restrição. A higienização das mãos, dos produtos, a procedência do alimento, como deve ser armazenado e muitas 
outras coisas são observadas para evitar contaminação. Quando estamos na produção, precisamos verificar como o alimento está sendo preparado, como será enviado ao paciente, verificar o uso de máscara e luva, a limpeza com álcool das mãos, dos utensílios e das bancadas." (N2)

As IRAS elevam consideravelmente os custos no cuidado do paciente, além de aumentar o tempo de internação, a morbidade e a mortalidade nos serviços de saúde do país. Dada à relevância desse problema, a ANVISA revisou a publicação Medidas de Prevenção de Infecção Relacionada à Assistência à Saúde para contribuir na redução da incidência das IRAS, a partir da disponibilização das principais medidas preventivas das infecções do trato respiratório, trato urinário, corrente sanguínea e sítio cirúrgico adequadas à realidade brasileira (Brasil, 2017b).

De acordo com a WHO (2011), deve-se discutir com os alunos as ações para minimizar as IRAS de maneira que eles sejam capazes de, no decorrer da sua formação e mais tarde na atuação profissional, conhecer as diretrizes de prevenção do seu local de atuação, responsabilizar-se individualmente na prática para a redução da transmissão de infecções e educar pacientes e familiares sobre a higiene das mãos e a transmissão de infecções.

Outro ponto importante na abordagem com os alunos diz respeito à segurança nos procedimentos invasivos e cirúrgicos. Os estudos mostram que milhares de pessoas morrem em decorrência direta do procedimento cirúrgico e outras tantas experimentam complicações, por causa das muitas oportunidades para algo dar errado nas múltiplas etapas envolvidas nesse tipo de procedimento. Além disso, as infecções relacionadas aos procedimentos invasivos e cirúrgicos representam uma proporção significativa das IRAS (WHO, 2011).

Com o intuito de reduzir os danos ao paciente, o Segundo Desafio Global para a Segurança do Paciente focou a atenção nos fundamentos e práticas da segurança cirúrgica, que consistem na divulgação de objetivos essenciais para a cirurgia segura, na formulação de indicadores de dados estatísticos cirúrgicos para medir o progresso e na elaboração de lista de verificação de segurança cirúrgica, a qual deve ser realizada em cada procedimento cirúrgico (WHO, 2009c).

"Em relação à segurança nos procedimentos invasivos, a lateralidade foi bem abordada. Tudo que tem direita e esquerda dá problema, precisa verificar o lado 
correto. Isso foi falado na faculdade e no hospital novamente. Acabei vendo mais o pessoal da enfermagem fazendo isso do que nós mesmos. Geralmente no préoperatório o médico passa e o interno vai atrás e verifica o lado, mas quem faz a marcação, indica naquele boneco do prontuário que tem desenhado a lateralidade, é a enfermagem. Os médicos negligenciam um pouco isso e confiam... Se uma perna está exposta e a outra coberta, então é porque é na exposta que o procedimento deve ser feito, eles não conferem antes de iniciar o procedimento. Nem quando tivemos Técnicas Cirúrgicas o tema foi abordado, pois tivemos lavagem de mãos, paramentação adequada, sutura... A parte da cirurgia segura não foi discutida. No hospital privado onde passamos para acompanhar a anestesia era outra realidade, tinha protocolo, mas no nosso hospital escola, SUS, percebemos que muita coisa passa batido." (M1)

Os campos de estágio possuem corresponsabilidade na formação dos futuros profissionais, pois não basta aprender na sala de aula as melhores práticas para a segurança do paciente se, na realidade do serviço de saúde, o aluno depara-se com um sistema que não utiliza ou subutiliza os protocolos assistenciais (Cauduro et al., 2017).

Para haver o cuidado seguro, cada membro da equipe precisa saber o que é esperado dele, considerando-se os protocolos, diretrizes e checklists instituídos. Se uma dessas ferramentas não for utilizada consistentemente pela equipe toda ou se os profissionais pularem etapas deliberadamente, a ferramenta não protegerá os pacientes de eventos adversos (WHO, 2011).

Ainda de acordo com a WHO (2011), é essencial sensibilizar os futuros profissionais sobre o valor dos protocolos, diretrizes e listas de verificação na redução de erros e diminuição de danos ao paciente. Para isso, cada indivíduo precisa compreender e confiar que tais ferramentas contribuem para melhorar a assistência à saúde ao facilitar a comunicação entre os membros da equipe, incluindo o paciente, evitando que o paciente errado receba um tratamento errado. 


\subsection{SEGURANÇA E QUALIDADE COMO ELEMENTOS FUNDAMENTAIS NA CADEIA MEDICAMENTOSA}

A cadeia medicamentosa inclui os processos de prescrição, dispensação e administração de medicamentos, cada qual com diferentes profissionais envolvidos e com potenciais falhas na execução em seus subprocessos. É, portanto, de extrema relevância para as questões relacionadas à segurança do paciente.

Nesse sentido, a categoria aborda a percepção dos alunos no que concerne à vulnerabilidade do paciente e dos processos que envolvem toda a cadeia medicamentosa.

De acordo com a WHO (2011), os futuros profissionais precisam entender a natureza do erro e quais os danos estão associados ao uso de medicamentos, além de aprender como tornar esse processo mais seguro.

O Terceiro Desafio Global para a Segurança do Paciente lançado em março de 2017 e denominado "Medicação sem dano" teve como principal desafio reduzir a frequência e o impacto de danos severos e evitáveis relacionados ao uso de medicamentos, uma vez que todos os erros de medicação são potencialmente evitáveis e podem ser muito reduzidos melhorando os sistemas e práticas de toda a cadeia medicamentosa (WHO, 2017).

A experiência de outras indústrias de alto risco e os estudos realizados por especialistas demonstram que os seres humanos raramente cometem erros por negligência; os erros ocorrem em razão de sistemas e os processos de trabalho defeituosos ou disfuncionais. O aumento de erros e danos relacionados à medicação não é exceção à regra, pois ocorrem em razão do sistema frágil e por influência de fatores humanos como a fadiga, as condições precárias do ambiente e a falta de pessoal nas etapas de prescrição, transcrição, dispensação, administração e monitoramento. Contudo os erros ocorrem com maior frequência durante a etapa de administração (WHO, 2017).

"Nesse item sobre medicação, a letra é um grande problema. No internato tivemos professores que valorizavam que a letra estivesse bonita, o nome do medicamento sempre em letra de forma para o paciente entender; devíamos explicar como tomar, se o paciente era analfabeto tinha que fazer um esquema numa outra 
folha, mas tem outros preceptores que não se preocupam com isso. Depois, nem o farmacêutico entende e o paciente não toma direito a medicação. Os professores das áreas que lidam com pessoas mais idosas, a geriatria e a cardiologia, sempre ficavam bem atentos se estávamos fazendo o receituário com letra legível e se o explicávamos ao paciente com atenção." (M1)

Problemas na legibilidade da prescrição podem comprometer a comunicação entre prescritor e paciente e/ou demais profissionais de saúde, sendo geradora importante de erros de medicação, sobretudo a troca de medicamentos com nomes parecidos. Com o intuito de melhorar a legibilidade das prescrições, o "Protocolo de segurança na prescrição, uso e administração de medicamentos" publicado pelo Ministério as Saúde e ANVISA recomenda a utilização de prescrições digitadas e eletrônicas (Brasil, 2013f).

Os erros relacionados à fase de prescrição podem envolver a comunicação inadequada no que tange à ilegibilidade e uso de abreviações, paciente errado, doses erradas, drogas erradas e via de administração errada. Tais erros podem estar relacionados com a inexperiência ou conhecimento inadequado do prescritor no que se refere à indicação, contraindicação e interações entre as drogas, bem como podem ser resultado de descuido ou fadiga (WHO, 2011).

"A letra da receita é outro problema. Vamos nos acostumando, mas quando não conseguimos entender, temos a obrigação de ligar para o médico e falar: não estamos conseguindo identificar essa prescrição do paciente. Caso o farmacêutico não consiga contato com o médico, é registrado o motivo de não ter dispensado. $O$ farmacêutico, pela legislação, é proibido de dispensar qualquer medicamento, fármaco ou substância que esteja em um receituário que ele não consiga identificar. Inclusive, ele pode ser penalizado se dispensar um fármaco que estiver errado. Mas não me lembro de falarmos sobre quando pegarmos uma prescrição errada; é uma boa questão para discutir com o professor do estágio.” (Fa1)

O farmacêutico tem, entre suas funções, a dispensação dos medicamentos e deve assegurar que eles estejam disponíveis para administração ao paciente no tempo adequado, na dose correta, assegurando a manutenção das características físicas, químicas e microbiológicas, contribuindo para o seu uso seguro. Tanto em 
farmácias ambulatoriais como hospitalares, as etapas de recebimento da prescrição, separação e dispensação dos medicamentos ao paciente devem ser realizadas com dupla conferência dos medicamentos em ambiente exclusivo para essa finalidade (Brasil, 2013f).

A WHO (2011) recomendou alguns pontos de atenção no momento da dispensação dos medicamentos, tais como confirmar se a receita está correta e completa; atentar-se às abreviações e aos medicamentos com nomes ou sons parecidos; reduzir distrações e organizar o local de trabalho, entre outros.

"O item segurança no processo de medicação foi falado o tempo inteiro. Os cinco certos, que agora são 11, foram muito citados tanto nas aulas em sala $e$ laboratório como nos estágios." (E3)

A etapa de administração é a última barreira para evitar um erro de medicação derivado dos processos de prescrição e dispensação, aumentando, com isso, a responsabilidade do profissional que administra os medicamentos (Brasil, 2013f).

Portanto, os profissionais de enfermagem, responsáveis pelo preparo, administração e monitoramento dos medicamentos, precisam estar conscientes e seguros de suas ações e possuir conhecimentos e acesso às informações necessárias para eliminar incertezas e dúvidas de modo a reduzir os fatores de risco para a ocorrência de erros nessas etapas da cadeia medicamentosa (COREN-SP, 2017).

Tradicionalmente tem sido enfatizada a utilização dos cinco certos no preparo e na administração de medicamentos pela equipe de enfermagem: paciente certo; medicamento certo; via certa; hora certa e dose certa (WHO, 2011). Entretanto, o estudo de Malcolm e Yisi (2010) recomenda o uso dos nove certos, que contém quatro outros itens de verificação: registro certo, ação certa, forma certa e resposta certa.

O uso dos nove certos não garante que os erros de administração não ocorrerão, mas pode prevenir parte significativa desses eventos, melhorando a segurança e a qualidade da assistência prestada ao paciente durante o processo de administração de medicamentos (Malcolm, Yisi, 2010; Brasil, 2013f). 
É importante considerar também os fatores ambientais que podem interromper e distrair o profissional durante a sua atividade e aumentar, assim, a possibilidade de erros relacionados ao preparo e à administração de medicamentos. Tais fatores relacionam-se à disponibilidade de materiais e medicamentos adequadamente, local limpo, organizado, com espaço e iluminação suficientes e livres de ruídos excessivos.

Um estudo australiano com mais de 4 mil observações diretas das etapas de preparo e administração de medicamentos evidenciou que as interrupções estão associadas ao aumento de $12,1 \%$ nas falhas processuais e de $12,7 \%$ nos erros clínicos, assim como a gravidade do erro aumentou de acordo com o número de interrupção (Westbrook et al., 2010).

Outro ponto importante para a prevenção de erros na cadeia medicamentosa está relacionado ao envolvimento do paciente - desde a realização do histórico com informações completas e precisas sobre os medicamentos utilizados, doses, horários e alergias - e à prática educativa; ambos garantem que paciente ou seus familiares entendam e participem das decisões sobre o tratamento colaborando, também, na segurança desse complexo processo (COREN-SP, 2017; WHO, 2011).

"Em relação ao último tópico [melhorar a segurança do processo de medicação], o que podemos fazer é orientar o paciente a procurar outro profissional, um farmacêutico ou um médico, e se tiver algum pedido médico com o qual não concordamos, precisamos conversar com o profissional e explicar a melhor conduta de acordo com a nossa avaliação." (Fi2).

Os profissionais da área da saúde deparam-se na prática cotidiana, direta ou indiretamente, com os processos complexos inerentes à cadeia medicamentosa na qual existe a vulnerabilidade dos pacientes em cada uma das etapas, pois assim como o uso de medicamentos gera melhoria na saúde, pode causar sofrimento e aumentar os custos de todo o sistema de saúde. Assim, cada profissional deve conhecer suas responsabilidades e atuar junto com os demais para uma prática segura. 


\subsection{ABORDANDO A TEMÁTICA SEGURANÇA DO PACIENTE: ESTRATÉGIAS E METODOLOGIAS DE ENSINO}

Essa última categoria retrata as sugestões dos alunos para a abordagem da temática segurança do paciente na formação profissional após terem contato com os 11 tópicos elencados no Guia Curricular durante a realização da entrevista.

Como já foi exposto anteriormente, para que os futuros profissionais ofereçam segurança no cuidado ao paciente nos diversos seguimentos de atuação na área da saúde, é necessário que tenham uma formação que contemple os conceitos de qualidade da assistência e a segurança do paciente, além da abordagem interdisciplinar que favoreça a prática colaborativa na equipe multiprofissional.

"No que diz respeito à sugestão de abordagem da segurança do paciente na graduação, eu acho que todos esses tópicos deveriam ser abordados em uma disciplina; poderia ser um semestre inteiro discutindo o assunto com os outros cursos, pois no hospital vamos trabalhar com a terapeuta ocupacional, com a fonoaudióloga e com a enfermagem e todos precisam aprender sobre isso." (Fi2)

Gilula e Barach (2009) descrevem que para mudar a cultura atual dos cuidados de saúde é importante que os alunos comecem a entender, apreciar e demonstrar habilidades relacionadas à segurança dos pacientes no início da educação profissional, pois trata-se de uma excelente oportunidade para influenciar a segurança da assistência à saúde por meio do ambiente educacional, dos métodos de ensino e dos currículos dos profissionais de saúde.

"Também seria interessante falar sobre o que é segurança; poderia ter uma disciplina para isso, porque não estudamos diretamente esse assunto: aprendemos ouvindo, vendo e percebendo alguns fatos, mas não formalmente. Vimos alguns conceitos na saúde do trabalhador que podem ser aplicados ao paciente, mas não é a mesma coisa." (M2).

"Deixo como sugestão abordar mais o segundo tópico, porque a aplicação de fatores humanos é importante para a segurança do paciente; a multidisciplinaridade 
também poderia ter sido também discutida de uma maneira diferente, para fixar mais a importância da equipe no cuidado ao paciente, talvez pudesse ter uma disciplina de eixo sobre segurança do paciente, com alunos de todos os cursos, como acontece em algumas disciplinas. Poderia utilizar simulação realística de eventos com o paciente contendo pessoas de diversas equipes diferentes... Eu acho que ficaria muito mais nítido para a gente a importância da multidisciplinaridade e seria bem melhor para a fixação do assunto." (E2)

A educação interdisciplinar em saúde é instrumento essencial para a assistência segura ao paciente. A incorporação de estratégias de ensino utilizando o trabalho em equipe e situações simuladas ou controladas em tempo real, que enfatizam a cooperação e a comunicação clara em um contexto de cuidados inseridos em sistemas complexos, pode melhorar significativamente o processo educacional e a prática assistencial no que concerne à segurança do paciente (Gilula, Barach, 2009; Zimmermann et al., 2015).

Sob essa ótica, estudantes da área da saúde podem ser beneficiados com um currículo que utilize a metodologia de aprendizagem baseada em problemas que encorajem a discussão e a colaboração, além das experiências simuladas que promovem aos alunos uma visão mais realística da prática assistencial e proporcionem o desenvolvimento de habilidades para atuação em situações complexas com foco na segurança do paciente (Kiersma, Plake, Darbishire, 2011; Zimmermann et al., 2015).

“O primeiro tópico [o que é segurança do paciente], por exemplo, é o básico para todos os profissionais, poderia ter nessa disciplina de eixo. O segundo tópico também é importante: tentar entender como alguns erros podem sofrer influência do ambiente. Quando discutimos sobre SUS, não focamos na segurança do paciente e na dificuldade dos encaminhamentos e do acesso ao paciente ao tratamento e o impacto disso na segurança dele.

Acho que seria interessante discutir que os profissionais erram e que isso pode acontecer com qualquer um. Então se eu errar, o que tenho que fazer? Tenho que notificar? Tenho que acompanhar por indicadores? Como as instituições acompanham essas notificações? Quais são os maiores problemas de segurança do paciente no contexto hospitalar? 
Talvez esteja faltando uma disciplina para incorporar esse assunto em algum momento da nossa vida acadêmica, porque eu só parei para pensar em segurança do paciente agora que conversamos sobre isso e percebi o quanto é importante." (T2)

Para a WHO (2011), os estudantes precisam aprender sobre a segurança do paciente, incluindo como a complexidade dos sistemas impactam na qualidade e na segurança da assistência, como as falhas na comunicação podem gerar eventos adversos e como as interações entre as pessoas e os equipamentos, a tecnologia e o ambiente influenciam na ocorrência de incidentes.

O estudo de Gilula e Barach (2009) recomenda que os conceitos básicos sobre segurança do paciente e qualidade da assistência sejam introduzidos nos primeiros anos do curso de graduação, seguidos pela prática supervisionada e a aplicação desse conhecimento durante os ensinos clínicos, com reforço periódico de temas como: a educação do paciente e seus familiares como membros da equipe nos estabelecimentos de saúde; trabalho em equipe interdisciplinar para criação da cultura de segurança; gerenciamento dos riscos e do erro por meio de relatórios e documentação; e uso de instrumentos e ferramentas para avaliação do serviço, análise causal e tendência de eventos adversos.

É possível notar nas falas dos participantes a necessidade da abordagem formal da segurança do paciente durante a formação acadêmica no que concerne aos conceitos básicos, bem como de aspectos relacionados ao gerenciamento de risco, a importância de se conhecer a natureza do erro, os fatores humanos e sistêmicos que favorecem sua ocorrência e a notificação de incidentes como forma de entender, mitigar e melhorar o processo assistencial na saúde.

Averiguamos, também, a necessidade da abordagem multiprofissional dessa temática, com o uso de metodologias que estimulem a participação efetiva de alunos dos diferentes cursos em práticas simuladas. 
CAPÍTULO 6

ANÁLISE INTERPRETATIVA À LUZ DO REFERENCIAL TEÓRICO

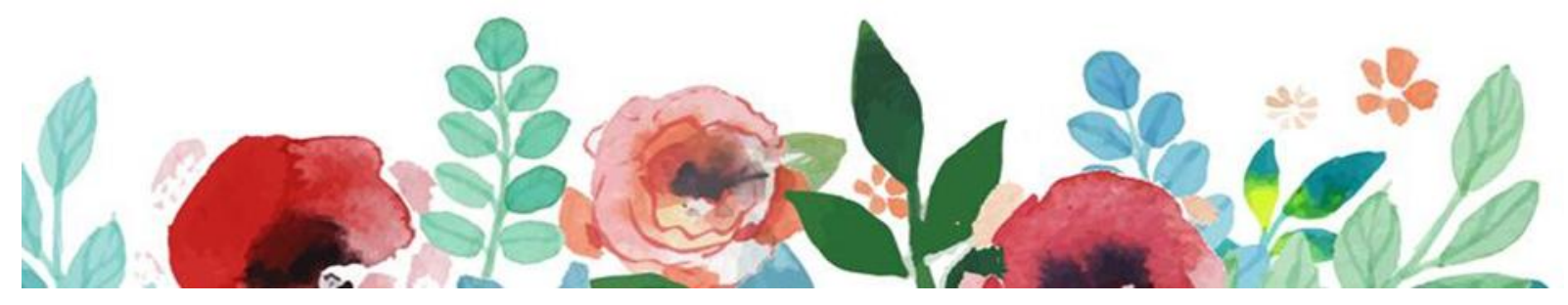



"A complexidade é um tecido de elementos heterogêneos inseparavelmente associados, que apresentam a relação paradoxal entre o uno e o múltiplo."

Edgar Morin

A análise das narrativas das entrevistas dos participantes culminou na definição das categorias e permitiu refletir, de forma mais incisiva, sobre a interdisciplinaridade na abordagem da temática segurança do paciente no âmbito da formação profissional.

Nesse sentido, adotamos como referencial teórico para fundamentar a análise interpretativa o filósofo e educador francês Edgar Morin, auxiliado por outros autores que discutem a interdisciplinaridade e a complexidade de forma que se possa atingir com mais profundidade a realidade e o aspecto multidimensional do fenômeno estudado.

Atualmente, vivenciamos a compartimentalização do conhecimento em especialidades cada vez mais peculiares, que não permitem a integração de um conjunto e do qual se considera apenas um aspecto. Assim, a superespecialização ou o recorte do conhecimento em disciplinas específicas e fechadas em si mesmas, torna impossível apreender "o que é tecido junto", o complexo, segundo o significado original do termo (Morin, 2011b p.14).

A fragmentação dos fenômenos complexos e multidimensionais impossibilita a compreensão e a reflexão por diferentes prismas e elimina as oportunidades de uma abordagem mais assertiva. Morin (2011b) descreve que apesar da superespecialização ter contribuído para a produção do conhecimento específico, trouxe consigo a ignorância e a cegueira em relação ao todo.

Nesse cenário, a interdisciplinaridade representa uma nova consciência da realidade e resulta na integração e na reciprocidade entre áreas distintas de conhecimento e objetiva a produção de novos conhecimentos e a resolução de problemas complexos (Peleias et al., 2011).

Sob essa ótica, correlacionando com a temática abordada nessa investigação, podemos afirmar que a segurança do paciente pode ser compreendida como um fenômeno complexo que envolve mundialmente os sistemas de saúde e que requer uma abordagem interdisciplinar, com a colaboração 
de todos os profissionais envolvidos na assistência à saúde compartilhando e agregando seus conhecimentos específicos na busca de novos conhecimentos e de modelos assistenciais que melhorem os resultados assistenciais nos diferentes níveis de atenção à saúde.

Apesar da crescente sensibilização dos profissionais de saúde em relação à importância da qualidade e segurança na assistência prestada, os pacientes, ainda, são amplamente acometidos por eventos adversos nos diferentes níveis de atenção dos sistemas de saúde. A percepção desse cenário favorece o entendimento de que a segurança do paciente é um problema complexo, que exige estratégias eficazes de prevenção de danos evitáveis e que as instituições de ensino preocupem-se, efetivamente, em formar profissionais de saúde com as competências necessárias para lidar com esse contexto e buscar a construção de sistemas de saúde mais seguros (NPFS, 2015).

Para que os diferentes profissionais de saúde colaborem e melhorem os resultados assistenciais, devem, essencialmente, ter oportunidade de aprender sobre os outros, com os outros e entre si para que possam desenvolver a prática colaborativa com base na integralidade da saúde e envolver os pacientes e comunidade para uma assistência qualificada e segura em todos os níveis do sistema de saúde (WHO, 2010).

É imprescindível, portanto, superar a fragmentação do conhecimento por meio de propostas educacionais emancipadoras, com base na mudança da concepção de mundo, na construção coletiva do conhecimento e, principalmente, na reflexão acerca da prática do cuidado articulado com outros processos interconectados entre eles (Mendonça, 2016).

Nas narrativas oriundas dos participantes, percebemos os princípios da interdisciplinaridade e da compreensão da complexidade da segurança do paciente, bem como a necessidade da abordagem transversal dessa temática durante a formação dos profissionais de saúde.

"[...] Precisamos ter aulas sobre segurança do paciente, as definições básicas e os conceitos, pois tivemos fragmentos do assunto, que me parece ser bem mais amplo. Eu acho que o tema devia ter sido abordado como disciplina de eixo para todos os cursos juntos e depois, em cada disciplina, os professores aprofundariam a discussão nas suas especialidades [...]." (T1) 
"Eu acredito que a segurança do paciente deveria ser abordada em diversas disciplinas no decorrer do curso, pois cada uma tem um foco e discutiria o assunto de acordo com sua especificidade. [...] pois o erro humano está presente em todas as áreas" (B2).

De acordo com Morin (2011a; 2011c), a estrutura de ensino pautada nas disciplinas isolam o objeto estudado do seu meio e não permite a integração desse objeto com as outras partes do todo. Assim, a educação deve romper com essas fragmentações para mostrar aos futuros profissionais de saúde as correlações entre os saberes, a complexidade do sistema de saúde e os problemas existentes.

O mesmo autor descreve, ainda, que a compartimentação dos saberes impede a compreensão da complexidade do todo, pois não permite que as partes se relacionem com a totalidade que, por sua vez, não se relaciona com as partes. Contudo os problemas complexos e transversais que recobrem diferentes disciplinas e áreas de atuação profissional, como a segurança do paciente, não podem ser tratados separadamente por apenas uma disciplina, devendo ser abordados na sua totalidade, incorporando os saberes específicos em um novo e compartilhado saber.

Para Morin (2011c), a interdisciplinaridade não desvaloriza as disciplinas e o conhecimento produzido por elas, mas incentiva o diálogo de um conhecimento com o outro como forma de ampliar o conhecimento do todo. Todavia, a dificuldade reside na articulação das partes com o todo e, nessa perspectiva, o papel do professor torna-se essencial, uma vez que é o responsável pelas interconexões significativas entre um saber e outro, as quais repercutirão sobre o modo do aluno pensar os novos conhecimentos, estabelecendo o sentido de integração com a realidade (Gasparian, 2010).

Morin (2011c) relata que a forma como as disciplinas estão estruturadas isolam os objetos do seu meio, assim como as partes do todo. A educação deve romper com essas fragmentações a fim de mostrar as correlações entre os saberes, a complexidade e os problemas atuais. Caso contrário, será sempre ineficiente e insuficiente para os profissionais do futuro, uma vez que a inadequação da maneira pela qual as disciplinas são trabalhadas, com saberes divididos e compartimentados, não está de acordo com a realidade é global, cuja tendência é propiciar, essencialmente, o resgate da unidade complexa. 
A complexidade dos sistemas de saúde impõe o reconhecimento da multidimensionalidade do ser humano e da necessidade de intervenções de abordagem interdisciplinar, uma vez que um profissional isoladamente não consegue dar conta de todas as dimensões do cuidado humano (Matos, Pires, 2009).

De acordo com a WHO (2011), a segurança do paciente é responsabilidade de todos e engloba desde pacientes e familiares até os gestores e políticos que elaboram e aprovam as políticas de saúde vigentes. Dessa forma, para que os profissionais de saúde sintam-se, também, responsáveis por essa totalidade, é imprescindível inserir a temática durante a formação profissional, não como uma disciplina autônoma e tradicional, mas integrando seus aspectos em todas as etapas de formação, nas diferentes áreas do cuidado à saúde, desenvolvendo conhecimento, habilidades e atitudes de modo que os futuros profissionais possam impactar positivamente nos resultados da assistência à saúde.

As falas a seguir ratificam as considerações da WHO no que tange à abordagem da segurança do paciente integrada aos conteúdos técnicos e específicos de cada curso de graduação, de forma que o conhecimento adquirido seja significativo para os discentes e contribua para a prática colaborativa, qualificada e segura.

"Talvez pudesse ter uma disciplina [...] que tratasse da segurança do paciente, os conceitos básicos importantes para todos os cursos e um pouco de cada um desses tópicos do manual; depois, cada disciplina específica poderia reforçar, durante a graduação, alguns assuntos que se relacionam." (Fi1).

"[...] acho que todos esses tópicos [do Guia Curricular] deveriam ser abordados em uma disciplina; poderia ser um semestre inteiro discutindo o assunto com os outros cursos, pois no hospital vamos trabalhar com a terapeuta ocupacional, com a fonoaudióloga e com a enfermagem e todos precisam aprender sobre isso." (Fi2)

Segundo Morin (2011c), perceber que as partes e os fenômenos estão conectados, favorece o entendimento do sujeito de que cada ação tem seu desdobramento e repercussão sobre uma dimensão maior (o todo) e que, em algum 
momento, isso recairá sobre ele (a parte). Da mesma maneira, para que o todo tenha êxito, é necessário que todas as partes sejam envolvidas nessa unidade.

O referido autor acrescenta, ainda, que a compreensão do impacto das partes no todo e do todo nas partes pode mudar a forma do profissional refletir, agir e se relacionar no que concerne à segurança do paciente na prática assistencial em saúde.

Reeves (2016) destaca que para a realização da assistência à saúde efetiva e segura é necessária a concretização da educação interdisciplinar na formação dos profissionais de saúde. No entanto os desafios relacionados a esse modelo de formação são concernentes ao desenvolvimento dos docentes, visto que para a maioria deles ensinar como aprender sobre determinadas temáticas, uns com os outros, é uma experiência nova e desafiadora.

Sob esse prisma, desenvolver as competências para 0 trabalho interdisciplinar no docente exige abranger algumas dimensões: experiência prévia, intencionalidade para o trabalho em grupo, flexibilidade e criatividade para vivenciar e compartilhar, por meio de projetos coletivos, as situações de aprendizado com os discentes. Não obstante, é importante a criação de uma cultura acadêmica que apoie as práticas colaborativas e interdisciplinares entre os docentes como uma práxis institucional (Batista, Batista, 2016).

Quando refletimos sobre a formação do profissional de saúde com foco na segurança do paciente, percebemos que para a efetiva integração dessa temática durante a construção do conhecimento acadêmico e da identidade profissional, um ponto crucial a se pensar é o envolvimento, a participação e a responsabilidade dos docentes na inserção dos princípios da assistência segura e qualificada e a repercussão disso nas instituições e na assistência ao indivíduo multidimensional inserido no complexo sistema de saúde.

Nessa direção, cabe repensar o preparo do docente para integrar a temática segurança do paciente no processo ensino-aprendizagem e agregá-la à sua experiência e especialidade direcionadas, até então, às questões teóricas e técnicas da formação profissional. A incorporação da segurança do paciente nas matrizes curriculares dos cursos e na prática docente influencia diretamente os discentes, uma vez que existe a tendência deles espelharem-se no comportamento de seus professores. Portanto, a importância dada a essa temática por cada docente poderá 
interferir na incorporação de atitudes conscientes e seguras por parte dos futuros profissionais.

Conforme Morin (2011b), diante da facilidade de acesso e da avalanche de informações que recebemos diariamente, devemos pensar nos efeitos, cada vez mais graves, da compartimentalização dos saberes e da incapacidade de articulálos, visto que quando fragmentamos a complexidade e a separamos em pedaços, o problema complexo e multidimensional torna-se unidimensional, o que de certa forma, atrofia as possibilidades de compreensão e de reflexão bem como elimina a oportunidade de uma visão completa do problema.

Por conseguinte, e frente aos pressupostos do referencial teórico adotado neste estudo, acreditamos na necessidade de pensarmos estratégias capazes de sensibilizar e instrumentalizar os docentes sobre a importância da inserção da temática segurança do paciente nos cursos de graduação na área da saúde, assim como sobre o relevante papel de cada docente ao influenciar o comportamento e as atitudes dos discentes no tocante às práticas colaborativas entre os profissionais da saúde, com foco em melhores resultados assistenciais nas diferentes áreas de atuação em saúde.

Diante do exposto neste Capítulo, é premente o estabelecimento de estratégias que atendam às peculiaridades de cada curso de graduação na área da saúde no que tange à inserção da temática segurança do paciente nas matrizes curriculares.

Corroborando com tal assertiva, o Capítulo 7 apresenta uma proposta de intervenção para o cenário desta investigação. 
CAPÍTULO 7

INSERÇÃO DA TEMÁTICA SEGURANÇA DO PACIENTE: PROPOSTA DE INTERVENÇÃO

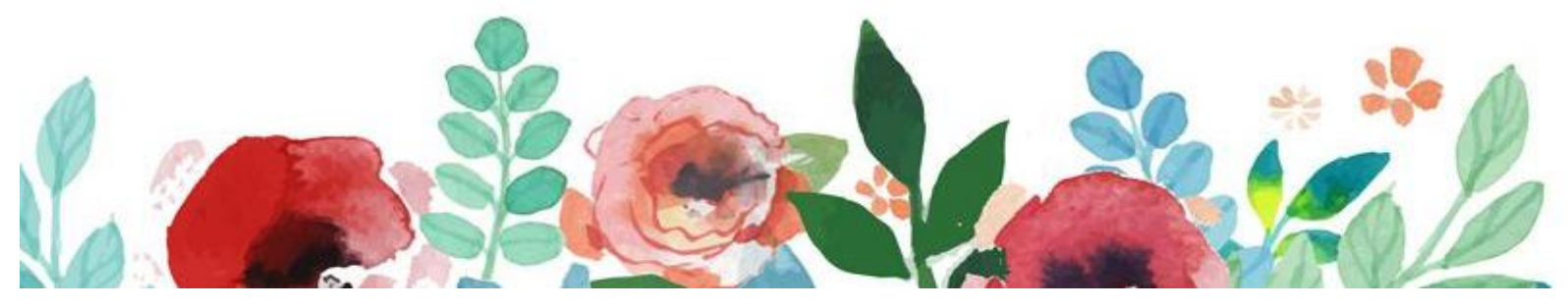



Feliz aquele que aprende o que ensina $e$ transfere o que sabe.”

Cora Coralina

No decorrer deste estudo tivemos a oportunidade de compreender como os discentes de setes cursos de graduação na área da saúde percebem a abordagem da segurança do paciente durante a sua formação acadêmica, além de conhecer suas sugestões para inserção dos aspectos gerais da temática, bem como dos assuntos específicos que compõem os 11 tópicos do Guia Curricular da WHO.

Entretanto, constatamos que para a implantação efetiva da referida temática na formação dos profissionais de saúde, há a necessidade primeiramente de sensibilizar os docentes, de forma a incorporá-la e valorizá-la no processo ensinoaprendizagem.

Para a WHO (2011), a formação dos profissionais de saúde não tem acompanhando o ritmo acelerado das mudanças e os desafios atuais do setor, no que concerne ao desenvolvimento das competências necessárias para a realização da assistência à saúde qualificada e segura, na sua perspectiva multiprofissional e englobando as complexas relações inerentes aos sistemas de saúde.

A mesma publicação aponta, ainda, que um dos fatores dificultadores na inserção da segurança do paciente na formação dos profissionais é a falta de reconhecimento, por parte dos docentes, da essencialidade da temática nos currículos. Outro ponto refere-se à falta de familiaridade dos docentes em relação à literatura sobre segurança do paciente, o que causa obstáculos na incorporação da temática aos currículos existentes (WHO, 2011).

Kiersma, Plake e Darbishire (2011) apontaram em seu estudo que, além da qualidade e segurança do paciente não serem consideradas prioridades frente ao ensino da prática clínica, a falta de confiança do docente em ensinar e relacionar a sua especialidade técnica com esse conteúdo interfere no engajamento dos estudantes em relação às temáticas.

Pesquisa de Robb et al. (2017) vai ao encontro do estudo acima ao concluir que as principais barreiras para incorporar os conceitos da melhoria da qualidade e segurança do paciente nos currículos dos cursos da área da saúde estavam relacionadas ao excesso de disciplinas existentes e ao conhecimento limitado por parte dos professores no que concerne às temáticas em questão. 
Desse modo, faz-se necessário sensibilizar os docentes em relação à inserção da temática segurança do paciente de forma que seja agregada à sua área de atuação e influencie positivamente tanto na formação da identidade profissional dos alunos como na melhoria dos processos assistenciais nas instituições de saúde (Bohomol, Freitas e Cunha, 2016).

Nesse sentido, urge ampliar a abordagem da segurança do paciente de forma a estar presente transversalmente no currículo acadêmico, favorecendo a aprendizagem significativa dessa temática no decorrer da formação dos futuros profissionais de saúde.

Para tanto, optamos por elaborar uma proposta de capacitação docente que permita fomentar a construção do conhecimento de maneira interdisciplinar e que contribua para a articulação, de forma sinérgica, entre os conteúdos sobre segurança do paciente e as disciplinas que compõem a grade curricular dos cursos de graduação na área da saúde.

A referida proposta de intervenção, visando à capacitação docente em segurança do paciente, será apresentada e submetida à análise da coordenação geral de graduação e dos coordenadores de cada curso, de modo que possa abranger conjuntamente todos os professores que atuam nos cursos de graduação na área da saúde da IES, cenário deste estudo.

A Figura 4 retrata o arcabouço de uma proposta de intervenção estimada em, aproximadamente, cinco meses de duração, de modo que as sugestões para a inserção da segurança do paciente nas matrizes curriculares dos cursos de forma interdisciplinar possam ser aprovadas e incorporadas à IES no semestre seguinte à finalização de todas as etapas.

Figura 4 - Esquema para operacionalização da capacitação docente e inserção da segurança do paciente nas matrizes curriculares. São Paulo, 2018.

\section{ETAPA 1: WORKSHOP DE SENSIBILIZAÇÃO}

\section{ETAPA 2: GRUPO FOCAL}

\section{ETAPA 3: ANÁLISE DAS MATRIZES CURRICULARES}

\section{ETAPA 4: SÍNTESE E OPERACIONALIZAÇÃO}


Cabe ressaltar que a formação do docente é um elemento de desenvolvimento pessoal e profissional, porém a IES deve investir na capacitação do seu capital humano, compartilhando a preocupação e a responsabilidade da formação e expectativa dos discentes frente ao mercado de trabalho (Perrenoud, Paquay e Altet, 2001).

A primeira etapa proposta para a capacitação docente, portanto, será programada para o evento de integração que ocorre no início de cada semestre letivo, na ocasião do retorno dos docentes às suas atividades acadêmicas, após o recesso ou férias. Esse acontecimento conta com a presença dos docentes dos diferentes cursos de graduação da referida IES.

Para a operacionalização dessa primeira etapa, estão previstos workshops com a participação do maior número possível de docentes a fim de que a temática seja apresentada e discutida de forma interdisciplinar, conforme proposta detalhada no Quadro 6.

Quadro 6 - Proposta para o desenvolvimento da capacitação docente sobre segurança do paciente. São Paulo, 2018.

\begin{tabular}{|c|c|}
\hline & ETAPA 1: WORKSHOP DE SENSIBILIZAÇÃO \\
\hline OBJETIVOS & $\begin{array}{l}\text { - Apresentar a temática segurança do paciente aos docentes da } \\
\text { IES; } \\
\text { - Oportunizar a reflexão sobre a relação entre a segurança do } \\
\text { paciente e a formação profissional em saúde; } \\
\text { - Apresentar o Patient Safety Curriculum Guide: Multi-professional } \\
\text { edition. }\end{array}$ \\
\hline ESTRATÉGIAS & $\begin{array}{l}\text { - Exposição dialogada; } \\
\text { - } \text { Apresentação do vídeo, disponível em: } \\
\text { https://www.youtube.com/watch?v=nCOcl-uS2 U } \\
\text { - Momento para reflexão e questionamentos. }\end{array}$ \\
\hline CONTEÚDO & $\begin{array}{l}\text { - Conceitos e aspectos históricos sobre a segurança do paciente; } \\
\text { - Cenário atual; } \\
\text { - Principais iniciativas da WHO; } \\
\text { - Apresentação do Patient Safety Curriculum Guide: Multi- } \\
\quad \text { professional edition. }\end{array}$ \\
\hline
\end{tabular}


Ao final da primeira etapa, os professores interessados ou indicados por cada coordenação dos cursos de graduação serão convidados a participar de grupos focais para discussões aprofundadas sobre a temática segurança do paciente em encontros previamente agendados que ocorrerão aproximadamente a cada 15 dias, na própria IES.

O grupo focal tem sido amplamente empregado em diversas áreas da produção de conhecimentos, entre as quais as pesquisas em saúde, pois é reconhecido como ambiente privilegiado de discussão e troca de experiências acerca de uma determinada temática, visto que seu formato estimula o debate entre os participantes, permitindo que os temas abordados sejam mais problematizados que numa situação de abordagem individual (Trad, 2009; Backes et al, 2011).

Flick (2009) destaca que o objetivo das discussões em grupo focal é a análise de processos comuns, cuja solução do problema dever partir do grupo. Para isso, introduz-se um problema concreto e a tarefa do grupo é descobrir, por meio das discussões de alternativas, a melhor maneira de resolvê-lo. Assim é possível alcançar níveis crescentes de compreensão e aprofundamento acerca de uma determinada temática.

Nesta fase desta pesquisa, o objetivo do grupo focal será descobrir o nível de conhecimento dos docentes sobre segurança do paciente, assim como sua conduta em relação ao processo ensino-aprendizagem dessa temática, vinvulada às disciplinas ministradas.

O Quadro 7 retrata a proposta para o desenvolvimento do grupo focal, detalhando seus objetivos, estratégias e perspectiva para a condução dos quatro encontros programados, bem como a sugestão e disponibilização de materiais para leitura e acesso aos conteúdos que abordam a temática, tais como: vídeos, programas de treinamento e sites especializados, que podem contribuir para a aquisição de conhecimento dos docentes acerca da segurança do paciente. 
Quadro 7 - Proposta para desenvolvimento dos encontros de grupo focal com os docentes. São Paulo, 2018.

\section{ETAPA 2: GRUPO FOCAL}

- $\quad$ Aprofundar as discussões sobre a segurança do paciente com os docentes;

- Discutir sobre a interdisciplinaridade na formação dos profissionais OBJETIVOS de saúde;

- Relacionar a formação em segurança do paciente de modo interdisciplinar e contínua.

- $\quad$ Encontros previamente agendados, com duração de duas horas;

- Registro das informações relevantes;

- Utilização da técnica de brainstorming por meio de questões norteadoras;

ESTRATÉGIAS - Apresentação do material ilustrativo que norteou a coleta de dados desta pesquisa (Apêndice C);

- Apresentação das narrativas dos participantes;

- $\quad$ Sugestão de leituras, vídeos e cursos online gratuitos.

\section{Brainstorming}

- $\quad$ Como você percebe a temática segurança do paciente no ensino 1 ํ ENCONTRO de graduação?

- Em qual momento você acredita que aborda as questões relacionadas à segurança do paciente nas disciplinas que ministra?

\section{ENCONTRO disciplinas que você ministra?}

- $\quad$ Apresentação do material ilustrativo elaborado que retrata os 11 tópicos sugeridos pela WHO no Guia Curricular

- Discussão permeada pela questão norteadora: Como você acredita que cada um desses tópicos poderia ser inserido nas

- Apresentação de algumas narrativas dos participantes da pesquisa, relacionadas à abordagem dos tópicos do Guia Curricular.

- Disponibilização e sugestão de leitura Patient Safety Curriculum Guide - Multi-professional edition; 


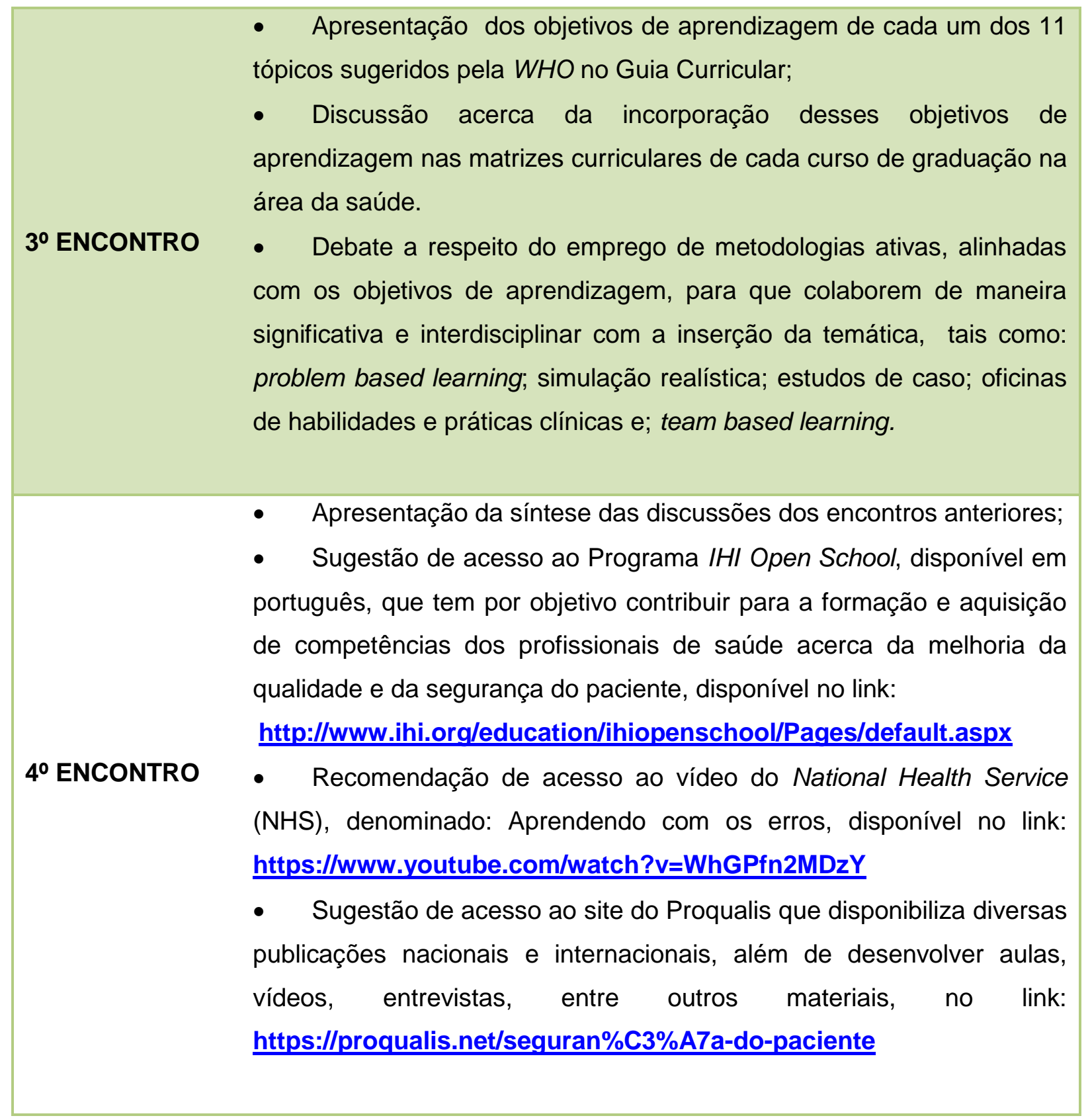

Concluída a segunda etapa, será iniciada a análise das matrizes curriculares dos cursos de graduação, de forma que seja possível oportunizar a incorporação de componentes da segurança do paciente junto aos objetivos pedagógicos das disciplinas existentes e, caso seja levantada a necessidade, a construção de uma disciplina que contemple os diferentes cursos de graduação e proporcione maior envolvimento dos discentes com as diferentes profissões que integram os serviços de saúde.

De acordo com a WHO (2011), quanto mais tópicos de segurança do paciente forem integrados ao currículo vigente, mais fácil será incorporar sua aprendizagem de maneira significativa, pois o professor especialista na área é envolvido e garante 
a contextualização do conteúdo da disciplina com os tópicos de segurança do paciente pertinentes.

É possível, também, incluir as noções iniciais de segurança do paciente em uma disciplina específica, ministrada em conjunto nos primeiros semestres dos cursos de graduação, e reabordar verticalmente os tópicos no decorrer de cada curso, de acordo com os objetivos pedagógicos estabelecidos. Cabe ressaltar que o melhor momento para aprender sobre segurança do paciente em determinado procedimento é quando se aprende a realizar as etapas desse procedimento (WHO, 2011).

O Quadro 8 representa a proposta para o desenvolvimento da revisão das matrizes curriculares, de modo que os objetivos de aprendizagem dos 11 tópicos contidos no Guia Curricular sejam abordados, de modo transversal e interdisciplinar, durante a formação acadêmica dos futuros profissionais de saúde.

Quadro 8 - Proposta para o desenvolvimento da revisão das matrizes curriculares dos cursos de graduação na área da saúde. São Paulo, 2018.

\section{ETAPA 3: REVISÃO DAS MATRIZES CURRICULARES}

- Avaliar as disciplinas que compõem a matriz curricular de cada curso de graduação para definir a melhor estratégia de inserção dos tópicos de segurança do paciente;

OBJETIVOS

- Integrar os objetivos de aprendizagem dos tópicos do Guia Curricular nas disciplinas de cada curso de graduação em saúde da IES;

- Avaliar a necessidade da criação de uma disciplina que incorpore e integre os cursos de graduação para abordagem da temática.

- Apropriação do conteúdo do Guia Curricular pelos docentes especialistas de cada curso de graduação;

- Avaliação dos objetivos de aprendizagem de cada tópico do Guia Curricular;

ESTRATÉGIAS

- Adequação dos objetivos de aprendizagem das disciplinas com os tópicos de segurança do Guia Curricular;

- Encontros previamente agendados para discussão acerca da integração dos objetivos de aprendizagem do Guia Curricular com as disciplinas do curso. 
O desenvolvimento desta etapa ocorrerá em parceria com a pesquisadora, os docentes que participaram da segunda etapa de capacitação e os docentes especialistas nas disciplinas que compõem a matriz curricular dos cursos de graduação, de modo que seja possível integrar os objetivos de aprendizagem sugeridos no Guia Curricular.

Segundo a WHO (2011), há a necessidade de se pensar como coordenar o momento oportuno e o formato adequado para que o processo ensino-aprendizagem sobre a segurança do paciente ocorra. Tal reflexão requer uma análise desafiadora por parte do docente para verificar se os elementos acerca dessa temática podem ser incorporados às atividades de ensino existentes, ampliando a abordagem holística do ensino na área da saúde.

Outro ponto fundamental ressaltado versa acerca da maximização das oportunidades para a aprendizagem ativa, nas quais os discentes se envolvem no processo de ensino de maneira significativa em vez de receberem passivamente as informações (WHO, 2011).

Nesse contexto, a WHO (2011) sugere que cada disciplina ou área do conhecimento avalie, junto aos seus especialistas, se existe a abordagem da segurança do paciente, como está sendo ensinada e avaliada ou se existe potencial para aprendizagem da temática.

Dessa forma, para que o levantamento das informações de cada disciplina dos cursos ocorra de forma mais homogênea possível, sugerimos o preenchimento de uma ficha contendo informações decorrentes da discussão e consenso entre os docentes responsáveis por tal disciplina, para posterior diagnóstico situacional, análise e intervenção.

A Figura 5 exemplifica o modelo idealizado para o levantamento das informações acerca da segurança do paciente das disciplinas 
Figura 5 - Modelo de ficha para levantamento das informações de cada disciplina dos cursos de graduação. São Paulo, 2018.

Curso:
Disciplina:
Há conteúdo de segurança do paciente? Se sim, discorra sucintamente.
Como a segurança do paciente está sendo ensinada (estratégia de ensino)?
Há potencial para abordar a segurança do paciente nesta disciplina? Se sim,
discorra sucintamente.
É possível relacionar com algum objetivo de aprendizagem dos tópicos sugeridos
no Guia Curricular?

Após a análise das informações contidas nas fichas referentes a cada disciplina, será discutida e desenvolvida, junto com os docentes dos cursos e especialistas das disciplinas, uma proposta abrangente de inclusão da segurança do paciente, considerando os objetivos de aprendizagem dos tópicos sugeridos no Guia Curricular, bem como os objetivos de cada disciplina que contemplará a temática.

Depois de finalizada, a proposta será apresentada aos coordenadores dos cursos e à coordenação geral de graduação e, posteriormente, discutida no colegiado de cada curso para análise e aprovação das sugestões.

Os objetivos e as estratégias da etapa final de intervenção deste estudo estão elencados no Quadro 9. 
Quadro 9 - Proposta de inserção dos tópicos de segurança do paciente nas matrizes curriculares. São Paulo, 2018.

\section{ETAPA 4: SÍNTESE E OPERACIONALIZAÇÃO}

- Apresentar aos coordenadores de curso e coordenação geral de graduação a proposta de integração da temática segurança do paciente nos planos de ensino das matrizes curriculares dos

OBJETIVOS cursos de graduação em saúde da IES, com o emprego de
metodologias ativas de ensino e da interdisciplinaridade;

- Aprovar e implantar as alterações nos planos de ensino que compõem as matrizes curriculares dos cursos de graduação em saúde da referida IES.

- Apresentação dos objetivos de aprendizagem de cada tópico do Guia Curricular e como foram integrados aos objetivos de aprendizagem das disciplinas dos cursos;

\section{ESTRATÉGIA}

- Apresentação, discussão e aprovação nos colegiados dos cursos acerca da implementação das alterações sugeridas nos planos de ensino das disciplinas que incorporaram a segurança do paciente conforme os tópicos do Guia Curricular.

Acreditamos que a intervenção proposta para a capacitação dos docentes e a inserção da segurança do paciente nas matrizes curriculares dos cursos de graduação em saúde contribuirá para a formação de futuros profissionais engajados nas questões relacionadas à qualidade da assistência e segurança do paciente, uma vez que o conhecimento relativo a essas temáticas será contextualizado e integrado aos conteúdos técnicos específicos de cada curso, contribuindo, dessa maneira, para a aprendizagem significativa. 
PERSPECTIVAS E DESAFIOS FRENTE À INSERÇÃO DA SEGURANÇA DO PACIENTE NA FORMAÇẨO DOS PROFISSIONAIS DE SAÚDE: CONSIDERAÇÕESS FINAIS

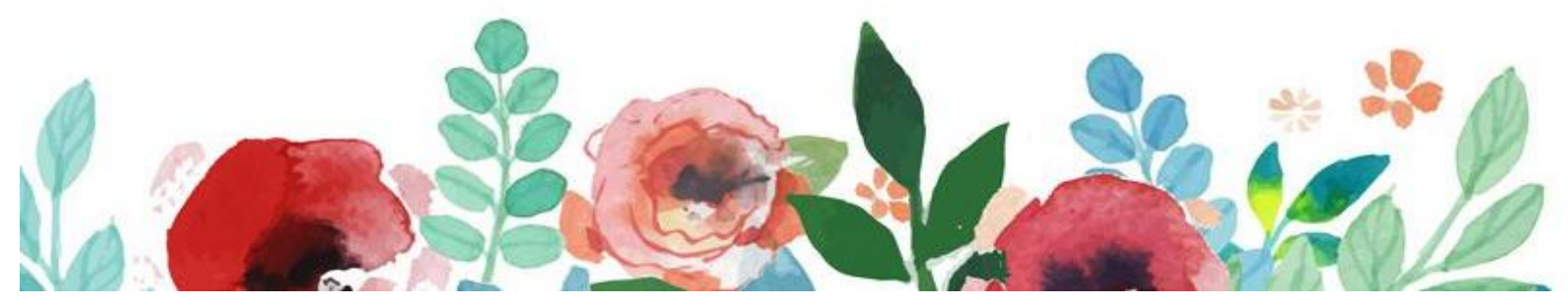



"Nós somos o que fazemos repetidamente. A excelência, portanto, não é um ato, mas um hábito.”

Aristóteles

O desenvolvimento deste estudo propiciou-nos compreender a percepção dos discentes de graduação dos cursos de enfermagem, medicina, fisioterapia, nutrição, terapia ocupacional, biomedicina e farmácia acerca da abordagem dos aspectos relacionados à segurança do paciente durante a sua formação profissional. O emprego do material ilustrativo elaborado a partir dos 11 tópicos sobre segurança do paciente sugeridos no Guia Curricular de Segurança do Paciente - edição multiprofissional da WHO para apoiar a condução das entrevistas colaborou para despertar reflexões relevantes acerca da temática.

Os resultados demonstraram que não há uniformidade na maneira pela qual a segurança do paciente é abordada nos diferentes cursos de graduação, uma vez que a temática pode estar inserida durante toda a formação e reforçada no momento do curso em que o discente inicia a prática clínica; pode ainda estar presente em algum tópico de uma disciplina específica ou aparecer de forma subliminar em conteúdos discutidos no decorrer do curso.

Percebemos que alguns tópicos, como os fatores humanos e sua relação com a segurança do paciente, a ocorrência e notificação dos erros na assistência à saúde e os conceitos relacionados à qualidade e suas ferramentas, não foram contemplados de forma homogênea entre os cursos de graduação. Com a falta da discussão sobre esses aspectos, muitas vezes, perpetua-se a cultura punitiva do erro ocorrido na assistência à saúde, com a visão de culpa individual e não com a abordagem ampliada sobre os processos e sistemas complexos nos quais os profissionais estão inseridos.

Evidenciamos, ainda, que a comunicação com o paciente assim como o trabalho em equipe foram discutidos nos cursos de graduação; entretanto não há uma abordagem interdisciplinar que permita aos futuros profissionais reconhecer a atuação e competência de cada participante da equipe e aprender a trabalhar juntos, incluindo o paciente e seu familiar para atingir melhores resultados assistenciais. 
Reconhecemos, portanto, a partir dos resultados, a necessidade da abordagem formal e equitativa da segurança do paciente no decorrer da formação acadêmica dos profissionais de saúde, por meio de uma estratégia interdisciplinar que estimulem a participação efetiva de alunos dos diferentes cursos compartilhando e agregando seus conhecimentos específicos na busca de novos conhecimentos e modelos assistenciais nos diferentes níveis de atenção à saúde.

Constatamos, todavia, que para a efetiva inserção da segurança do paciente durante a construção do conhecimento acadêmico e da identidade profissional, é necessária a sensibilização e a capacitação dos docentes, de modo que a valorizem e integrem essa temática, de forma contextualizada, nas disciplinas teóricas ou técnicas sob sua responsabilidade.

Por fim, podemos inferir que a integração da temática nas disciplinas que compõem as matrizes curriculares dos cursos de graduação, tanto nos conteúdos teóricos como na prática docente, influenciará diretamente no processo ensinoaprendizagem e na incorporação de atitudes e práticas conscientes por parte dos futuros profissionais e poderá colaborar na criação e no fortalecimento da cultura de segurança, na prática colaborativa, bem como impactar positivamente nos resultados assistenciais nas diferentes áreas de atuação em saúde. 
REFERÊNCIAS

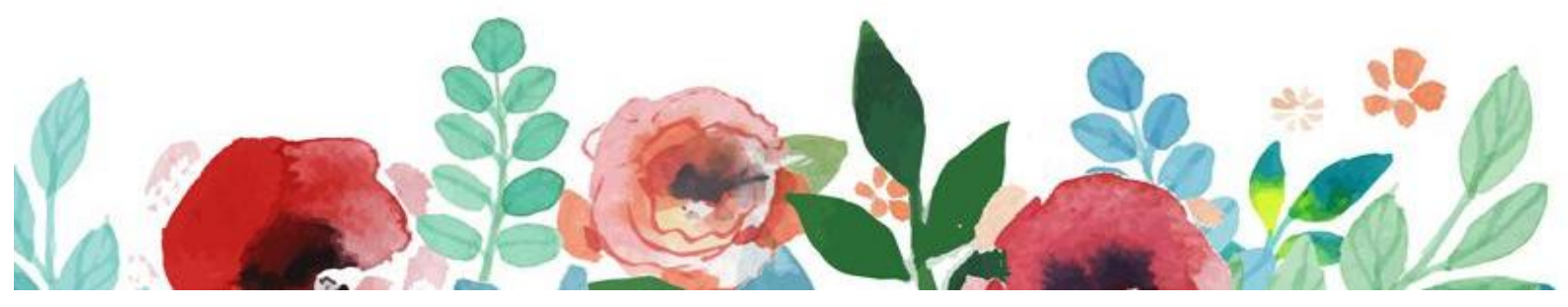



Aguilar-da-Silva R, Scapin LT, Batista NA. Avaliação da formação interprofissional no ensino superior em saúde: aspectos da colaboração e do trabalho em equipe. Avaliação: Revista da Avaliação da Educação Superior [Internet]. 2011 [cited 2017 Jan 25]; 16(1), 165-184. Available from: http://www.scielo.br/scielo.php?script=sci arttext\&pid=S141440772011000100009\&l $\underline{\mathrm{ng}}=\mathrm{pt \& nrm}=\mathrm{iso} \& \operatorname{lng}=\mathrm{pt}$

Australian Council on Safety and Quality in Health Care. National patient safety education framework. Canberra: Commonwealth of Australia 2005 [Internet]. 2005. [cited 2017 Jun 30]. Available from: https://www.safetyandquality.gov.au/wpcontent/uploads/2012/06/National-Patient-Safety-Education-Framework-2005.pdf

Backes DS, Colome JS, Erdmann RH, Lunardi VL. Grupo focal como técnica de coleta e análise de dados em pesquisas qualitativas. Mundo Saúde. 2011;35(4):43842.

Bank M. Dados visuais para a pesquisa qualitativa. Porto Alegre: Artmed; 2009.

Bardin L. Análise de conteúdo. Lisboa. São Paulo: Edições 70; 2011.

Batista NA, Batista SHSS. Educação interprofissional na formação em Saúde: tecendo redes de práticas e saberes. Interface (Botucatu) [Internet]. 2016 Mar [cited 24 jan. 2017]; 20(56):202-204. Available from: http://www.scielo.br/scielo.php?script=sci arttext\&pid=S141432832016000100202\&l $\underline{\mathrm{ng}}=\mathrm{pt \& nrm}=\mathrm{iso} \& \operatorname{lng}=\mathrm{pt}$

Bertonha V. Estudo sobre a formação de competências do estudante de graduação em enfermagem na vivência (simulada) em uma clínica de enfermagem. [tese]. São Paulo: Escola de Enfermagem, Universidade de São Paulo; 2007.

Bogarin DF, Zanetti ACB, Brito MFP, Machado JP, Gabriel CS, Bernardes A.; Segurança do paciente: conhecimento de alunos de graduação em enfermagem. Cogitare Enfermagem. 2014; 19(3):491-497.

Bohomol E, Cunha ICKO Ensino sobre segurança do paciente no curso de Medicina da Universidade Federal de São Paulo Einstein (São Paulo) [Internet]. 2015 Mar [cited 2017 Dec 22]; 13(1): 7-13. Available from: http://www.scielo.br/scielo.php?script=sci arttext\&pid=S167945082015000100003\&l $\underline{\mathrm{ng}=\mathrm{en}}$.

Bohomol E, Freitas MAO, Cunha ICKO. Ensino da segurança do paciente na graduação em saúde: reflexões sobre saberes e fazeres. Interface (Botucatu) [Internet]. 2016 Sep [cited 2017 Jan 25]; 20(58):727-741. Available from: http://www.scielosp.org/scielo.php?script=sci arttext\&pid=S14143283201600030072 7\&lng=en. Epub Mar 01, 2016. http://dx.doi.org/10.1590/1807-57622015.0699.

Branco Filho JRC. Segurança do paciente no cenário mundial e no Brasil: uma breve revisão histórica. In: Fonseca AS, Peterlini FL, Costa DA, organizadores. Segurança do Paciente.São Paulo: Martinari; 2014. p.1-10. 
Brasil. Agência Nacional de Vigilância Sanitária. RDC no 63 de 25 de novembro de 2011. Dispõe sobre os Requisitos de Boas Práticas de Funcionamento para os Serviços de Saúde [internet]. Brasília; 2011. [citado 01 out. 2015]. Disponível em: http://www20.anvisa.gov.br/segurancadopaciente/index.php/legislacao/item/rdc-63de-25-de-novembro-de-2011

Brasil. Conselho Nacional de Saúde. Resolução 466 de 12 de dezembro de 2012. Dispõe sobre diretrizes e normas reguladoras de pesquisas envolvendo seres humanos [internet]. Brasília; 2012 [citado 01 out. 2015]. Disponível em: http://conselho.saude.gov.br/resolucoes/2012/Reso466.pdf

Brasil. Agência Nacional de Vigilância Sanitária. Assistência Segura: Uma Reflexão Teórica Aplicada a Prática. [internet]. Brasília; 2013a. [citado 01 out. 2015]. Disponível em:

http://www20.anvisa.gov.br/segurancadopaciente/images/documentos/livros/Livro1Assistencia Segura.pdf

Brasil. Ministério da Saúde. Portaria 529 de $1^{\circ}$ de abril de 2013. Institui o Programa Nacional de Segurança do Paciente (PNSP). [internet]. Brasília: 2013b [citado 01 out. 2015]. Disponível em: http://bvsms.saude.gov.br/bvs/saudelegis/gm/2013/prt0529 0104 2013.html

Brasil. Agência Nacional de Vigilância Sanitária. RDC no 36 de 25 de julho de 2013. Institui ações para a segurança do paciente em serviços de saúde e dá outras providências. [internet]. Brasília: 2013c [citado 02 out. 2015]. Disponível em: http://bvsms.saude.gov.br/bvs/saudelegis/anvisa/2013/rdc0036 2507 2013.pdf

Brasil. Ministério da Saúde. Portaria № 1.377de 9 de julho de 2013. Aprova os Protocolos de Segurança do Paciente. [internet]. Brasília: 2013d [citado 18 ago. 2017]. Disponível http://bvsms.saude.gov.br/bvs/saudelegis/gm/2013/prt1377 0907 2013.html

Brasil. Ministério da Saúde. Portaria o 2.095 de 24 de setembro de 2013. Aprova os protocolos básico de segurança do paciente. [internet]. Brasília: 2013e [citado 18 ago. 2017]. Disponível em: http://bvsms.saude.gov.br/bvs/saudelegis/gm/2013/prt2095 2409 2013.html

Brasil. Ministério da Saúde. Agência Nacional de Vigilância Sanitária. Protocolo de segurança na prescrição, uso e administração de medicamentos. [internet]. Brasília: 2013f [citado 18 ago. 2017]. Disponível em: https://www20.anvisa.gov.br/segurancadopaciente/index.php/publicacoes/item/segur anca-na-prescricao-uso-e-administracao-de-medicamentos

Brasil. Ministério da Saúde. Fundação Oswaldo Cruz. Agência Nacional de Vigilância Sanitária. Documento de referência para o Programa Nacional de Segurança do paciente [internet]. Brasília: Ministério da Saúde; 2014. [citado 01 out. 2015]. Disponível em: http://bvsms.saude.gov.br/bvs/publicacoes/documento referencia programa nacion al seguranca.pdf 
Brasil. Agência Nacional de Vigilância Sanitária. Gestão de Riscos e Investigação de Eventos Adversos Relacionados à Assistência à Saúde. [internet]. Brasília; 2017a. [citado 17 ago. 2017]. Disponível em: https://www20.anvisa.gov.br/segurancadopaciente/index.php/publicacoes/item/cader no-7-gestao-de-riscos-e-investigacao-de-eventos-adversos-relacionados-aassistencia-a-saude

Brasil. Agência Nacional de Vigilância Sanitária. Medidas de Prevenção de Infecção Relacionada à Assistência à Saúde. [internet]. Brasília; 2017b. [citado 17 ago. 2017]. Disponível em: https://www20.anvisa.gov.br/segurancadopaciente/index.php/publicacoes/item/medid as-de-prevencao-de-infeccao-relacionada-a-assistencia-a-saude-3?category id=29

Brasil. Agência Nacional de Vigilância Sanitária. Pacientes pela segurança do paciente em serviços de saúde: Como posso contribuir para aumentar a segurança do paciente? Orientações aos pacientes, familiares e acompanhantes. [internet]. Brasília; 2017c. [citado 29 set. 2017]. Disponível em: https://www20.anvisa.gov.br/segurancadopaciente/index.php/publicacoes/item/guiacomo-posso-contribuir-para-aumentar-a-seguranca-do-paciente-orientacoes-aospacientes-familiares-e-acompanhantes

Brauer L, Dias CA. Conceito de Bundle para a segurança do paciente, segundo o IHI. In: Fonseca AS, Peterlini FL, Costa DA, organizadores. Segurança do Paciente.São Paulo: Martinari; 2014. p.71-9.

Caldana G, Guirardello EB, Urbanetto JS, Peterlini MAS, Gabriel CS. Rede Brasileira de Enfermagem e Segurança do Paciente: desafios e perspectivas. Texto contexto enferm. 2015; 24(3): 906-911.

Campos CJG. Método de análise de conteúdo: ferramenta para a análise de dados qualitativos no campo da saúde. Rev. Bras Enferm, Brasília (DF) 2004 set/out; 57(5):611-4.

Carvalho Vilma de. Acerca da interdisciplinaridade: aspectos epistemológicos e implicações para a enfermagem. Rev. esc. enferm. USP [Internet]. 2007 Sep [cited 2017 Jan 24]; 41(3):500-507. Available from: http://www.scielo.br/scielo.php?script=sci arttext\&pid=S008062342007000300022\&l ng=en. http://dx.doi.org/10.1590/S0080-62342007000300022.

Cassiani SHB. Enfermagem e a Pesquisa sobre Segurança dos Pacientes. Acta paul. enferm. [internet]. 2010 [cited 2015 Oct 02]; 23(6):vii-viii. Available from: http://www.scielo.br/scielo.php?script=sci arttext\&pid=S0103-21002010000600001

Castellanos MEP. A narrativa nas pesquisas qualitativas em saúde. Ciência \& Saúde Coletiva. [Internet] 2014 [cited 2017 Set 10]; 19(4):1065-1076. Available from: http://www.scielo.br/pdf/csc/v19n4/1413-8123-csc-19-04-01065.pdf

Cauduro GMR, Magnago TSBS, Andolhe R, Lanes TC, Dal Ongaro J. Segurança do paciente na compreensão de estudantes da área da saúde. Rev Gaúcha Enferm. 
[internet]. 2017 [cited 2017 Ago 11]; 38(2):e64818. Available from: http://www.scielo.br/pdf/rgenf/v38n2/0102-6933-rgenf-1983-144720170264818.pdf

Clack L, Sax H. Inpatient Notes: human factors engineering and inpatient care - new ways to solve old problems. Ann Intern Med. [internet]. 2017 [cited 2017 Jul 04] 166 166(8):HO2-HO3. Available from: http://annals.org/aim/article/2618426/annalshospitalists-inpatient-notes-human-factors-engineering-inpatient-care-new

Conselho Regional de Enfermagem de São Paulo (COREN-SP). Uso seguro de medicamentos: guia para preparo, administração e monitoramento/Conselho Regional de Enfermagem de São Paulo. - São Paulo: COREN-SP, 2017. 124p.

D'Innocenzo M; Adami NP; Cunha ICKO. O movimento pela qualidade nos serviços de saúde e enfermagem. Rev. Bras. Enferm. 2006; 59(1): 84-8.

Farley D, Zheng H, Rousi E, Leotsakos A. Field Test of the World Health Organization Multi-Professional Patient Safety Curriculum Guide. Dalby AR, ed. PLoS ONE. 2015;10(9):e0138510.

Fazenda ICA (org.). O que é interdisciplinaridade? 2ª ed. São Paulo: Cortez, 2013.

Flick U. Introdução à pesquisa qualitativa. Trad. de Joice Elias Costa. $3^{a}$ ed. Porto Alegre: Artmed; 2009.

Frank JR; Brien S (editors). The Safety Competencies - Enhancing Patient Safety Across the Health Professions. Ottawa (ON): Canadian Patient Safety Institute [internet]. 2008 [cited 2015 out 01]. Available from: http://www.patientsafetyinstitute.ca/en/toolsResources/safetyCompetencies/Docume nts/Safety\%20Competencies.pdf

Gasparian MCC. A interdisciplinaridade como metodologia de trabalho nas questões de aprendizagem e a construção do conhecimento da escola e da família. Construção psicopedagógica. [internet]. 2010 [cited 2017 Nov 03] 18(16), 129-150. Available from: http://pepsic.bvsalud.org/scielo.php?script=sci arttext\&pid=S1415695420100001000 $11 \& \operatorname{lng}=\mathrm{pt \& t} \operatorname{lng}=\mathrm{pt}$.

Gattás MLB. Interdisciplinaridade em Cursos de Graduação na Área da Saúde da Universidade de Uberaba [tese]. Ribeirão Preto: Escola de Enfermagem de Ribeirão Preto, Universidade de São Paulo; 2005.

Gil AC. Estudo de Caso: fundamentação científica, subsídios para coleta e análise de dados, como redigir o relatório. São Paulo: Atlas, 2009.

Gibbs G. Análise de dados qualitativos. Porto Alegre: Artmed; 2009.

Gilula MF, Barach PR. Patient safety education and curriculum design. In: Hurwitz B, Aziz S. Health Care Errors and Patient Safety. Blackwell Publishing; 2009 p.238 253. 
Headrick LA, Barton AJ, Ogrinc G, Strang C, Aboumatar HJ, Aud MA, et al. Results of an effort to integrate quality and safety into medical and nursing school curricula and foster joint learning. Health Aff (Millwood). [Internet]. 2012 [cited 2015 Oct 01]; 31(12):2669-2680. from: http://content.healthaffairs.org/content/31/12/2669.full.html

Inoue KC, Matsuda LM. Segurança do paciente: abordando um antigo problema. Cienc Cuid Saude [internet]. 2013 abr/jun. [cited 11 ago. 2017]; 12(2):208-209. Available http://eduem.uem.br/ojs/index.php/CiencCuidSaude/article/view/23880/13023

from:

Institute of Medicine (IOM). To err is human: building a safe Health System. Washington: National Academy Press; 2000.

Institute of Medicine (IOM). Health professions education: a bridge to quality. Washington DC, National Academy Press, 2003.

Japiassu H. Interdisciplinaridade e patologia do saber. Rio de Janeiro: Imago; 1976.

Joly, M. Introdução à análise da imagem. Campinas (SP): Papirus, 2012.

Jovchelovich S, Bauer MW. Entrevista Narrativa. In: Bauer MW, Gaskell G. Pesquisa qualitativa com texto, imagem e som: um manual prático. Petrópolis: Vozes; 2002, p. 90-113.

Kiersma ME, Plake KS, Darbishire PL. Patient Safety Instruction in US Health Professions Education. American Journal of Pharmaceutical Education. 2011; 75(8): 162.

Langer T, Martinez W, Browning DM, Varrin P, Lee BS, Bell SK. Patients and families as teachers: a mixed methods assessment of a collaborative learning model for medical error disclosure and prevention. BMJ Qual Saf [internet]. 2016 June. [cited 2017 ago. 11]; 25:615-625. Available from: http://qualitysafety.bmj.com/content/early/2016/06/22/bmjqs-2015-004292.full.pdf

Leape L. Errors in medicine. Clin Chim Acta. 2009; 404:2-5.

Leape L. Teaching Physicians to Provide Safe Patient Care. Lucian Leape Institute at National Patient Safety Foundation. Boston, MA [Internet]. 2010 [cited 2017 mar. 03]. Available https://c.ymcdn.com/sites/npsf.siteym.com/resource/resmgr/LLI/LLI-Unmet-NeedsReport.pdf

Leotsakos A, Ardolino A, Cheung R, Zheng H, Barraclough B, Walton M. Educating future leaders in patient safety. Journal of Multidisciplinary Healthcare. 2014; 7:381388.

Leung GHH, Patil NG. Patient safety in the undergraduate curriculum: medical student's perception. Hong Kong Med J 2010; 16(2):101-5. 
Ludke M. Pesquisa em educação abordagens qualitativas. $2^{\underline{a}}$ ed. Rio de Janeiro: EPU; 2013.

Malcolm E, Yisi L. The nine rights of medication administration: an overview. $\mathrm{Br} \mathrm{J}$ Nurs. 2010; 19(5):300-05.

Martins GA. Estudo de caso uma estratégia de pesquisa. 2ed. São Paulo: Atlas, 2008.

Matos E, Pires DEP, Campos GWS. Relações de trabalho em equipes interdisciplinares: contribuições para a constituição de novas formas de organização do trabalho em saúde. Rev. bras. enferm. [Internet]. 2009 Dec [cited 2017 Dec 22]; 62(6): 863-869. Available from: http://www.scielo.br/scielo.php?script=sci arttext\&pid=S003471672009000600010\&l $\underline{\mathrm{ng}=\mathrm{en}}$.

Meihy JCSS, Holanda F. História oral: como fazer, como pensar. $2^{\underline{a}}$ ed. São Paulo: Contexto, 2017.

Melleiro MM, Tronchin DMR, Lima MOPL, Garzin ACA, Martins MS, Cavalcante $M B G$, et al. Temática segurança do paciente nas matrizes curriculares de escolas de graduação em enfermagem e obstetrícia. Rev baiana enferm [Internet]. 2017 [cited 2017 jun. 26]; 31(1):e1681. Available from: https://portalseer.ufba.br/index.php/enfermagem/article/view/16814/pdf

Mendonça CTA. Vivência do enfermeiro em simulação de alta fidelidade no contexto da saúde [dissertação]. São Paulo: Escola de Enfermagem da Universidade de São Paulo, Universidade de São Paulo; 2016.

Miller R, Winterton T, Hoffman WW. Building a whole new mind: an interprofessional experience in patient safety and quality improvement education using the $\mathrm{IHI}$ Open School. S D Med. 2014 Jan; 67(1):17-9, 21-3.

Minayo MCS. Interdisciplinaridade: uma questão que atravessa o saber, o poder e 0 mundo vivido. Medicina Ribeirão Preto. 1991; 24(2):70-7.

Minayo MCS. Interdisciplinaridade: funcionalidade ou utopia: Saúde e sociedade 3(2): 42-64, 1994.

Minayo MCS. O desafio do conhecimento: pesquisa qualitativa em saúde. $14^{a} \stackrel{\text { ed. }}{ }$ São Paulo: Hucitec; 2014

Minayo MCS (org.), Deslandes SF, Gomes R. Pesquisa social: teorias, métodos e criatividade. Petrópolis, RJ: Vozes, 2016. (Série manuais acadêmicos).

Morin E. Os sete saberes necessários à educação do futuro. Trad. de Catarina Eleonora F. da Silva e Jeanne Sawaya. 2a ed. São Paulo: Cortez; 2011a.

Morin E. A cabeça bem-feita: repensar a reforma, repensar o pensamento. 19a ed. Rio de Janeiro: Bertrand Brasil; 2011b. 
Morin E. Introdução ao pensamento complexo. Trad. de Eliane Lisboa. 4a ed. Porto Alegre: Sulina; 2011c.

Muylaert CJ, Júnior VS, Gallo PR, Neto MLR, Reis AOA. Entrevistas narrativas: um importante recurso em pesquisa qualitativa. Rev Esc Enferm USP [Internet] 2014 [cited 2017 Set 10]; 48(Esp2):193-199. Available from: http://www.scielo.br/pdf/reeusp/v48nspe2/pt 0080-6234-reeusp-48-nspe2-00184.pdf

National Patient Safety Agency (NPSA) Seven steps to patient safety. The full reference guide. [Internet]. London: 2004 [cited 2017 Ago 17]; Available from: http://www.nrls.npsa.nhs.uk/resources/collections/seven-steps-to-patientsafety/?entryid $45=59787$

National Patient Safety Foundation (NPSF). Free from Harm: Accelerating Patient Safety Improvement Fifteen Years after To Err Is Human. Boston, MA [Internet]. 2015 [cited 2017 Mar. 03]; Available from: http://www.npsf.org/?page=freefromharm\#form

Nicolau M, Abath D, Laranjeira PC, Moscoso T, Marinho T, Nicolau V. Comunicação e semiótica: visão geral e introdutória à Semiótica de Peirce. Revista Eletrônica Temática. [internet] 2010 [cited 2017 Oct 25]; 6(8). Available from: http://www.insite.pro.br/2010/agosto/semiotica peirce nicolau.pdf

Nogueira JWS, Rodrigues MCS. Comunicação efetiva no trabalho em equipe em saúde: um desafio para a segurança do paciente. Cogitare Enferm. $2015 \mathrm{Jul} / \mathrm{set}$; 20(3): 636-640.

Pearson P, Steven A. Patient safety in health care professional educational curricula: examining the learning experience. Project Report. Patient Safety Education Study Group [Internet]. 2009 [cited 2017 Mar. 03]. Available from: http://www.surrey.ac.uk/fhms/research/centres/crnme/Completed\%20Projects/Report s/Patient\%20safety\%20in\%20health\%20care\%20professional\%20educational\%20cu rricula\%2008.pdf

Pedreira MLG. Práticas de enfermagem baseadas em evidências para promover a segurança do paciente [palestra]. Acta paul. enferm. 2009; 22 (especial 70 anos): 880-1.

Peduzzi M, Leonello VM, Ciampone MHT, Trabalho em equipe e prática colaborativa. In: Kurcgant P. (coord). Gerenciamento em enfermagem. $3^{\text {a }}$ ed. Rio de janeiro: Guanabara Koogan; 2016. p. 103-14.

Peduzzi M, Norman IJ, Germani ACCG, Silva JAM, Souza GC. Educação interprofissional: formação de profissionais de saúde para o trabalho em equipe com foco nos usuários. Rev. esc. enferm. USP [Internet]. 2013 Aug [cited 2017 Jan 24]; 47(4):977-983. Available from: http://www.scielo.br/scielo.php?script=sci arttext\&pid=S008062342013000400977\&l ng=en. http://dx.doi.org/10.1590/S0080-623420130000400029. 
Peirce CS. Semiótica. 3ª ed. São Paulo: Editora Perspectiva; 2003.

Peleias IR, Mendonça JF, Slomski VG, Fazenda ICA. Interdisciplinaridade no ensino superior: análise da percepção de professores de controladoria em cursos de ciências contábeis na cidade de São Paulo. Avaliação, 2011 nov; 16(3): 499-532.

Pepulim MEH, Fialho FAP, Souza RPL. Semiótica enquanto disciplinacientífica: uma ferramenta para uma comunicação eficaz. Perspectivas em Gestão \& Conhecimento, 2013 jul/dez; 3(2): 37-53.

Perrenoud P, Paquay L, Altet M, Charlier E. Formando professores profissionais: quais estratégias? Quais competências? 2ª Ed. Porto Alegre: Artmed; 2001.

Plaza J. Tradução intersemiótica. 2ª ed. São Paulo: Editora Perspectiva; 2010.

Polit DF, Beck CT, Hungler BP. Fundamentos de pesquisa em enfermagem: avaliação de evidências para a prática da enfermagem. $7^{\underline{a}}$ ed. Porto Alegre: Artmed; 2011.

Quinto Neto A. segurança dos pacientes, profissionais e organizações: um novo padrão de assistência à saúde. RAS. 2006; 33(8):153-8.

Ramalho e Oliveira SR, Gaspar DR, Ramalho e Oliveira GA. A contribution from semiotics towards visual communication within the field of healthcare. Interface (Botucatu) - Comunic., Saúde, Educ. 2009 abr./jun; 13 (29): 409-20.

Reason J. Human error: models and management. Brit Med J. 2000; 320:768-70.

Reeves Scott. Porque precisamos da educação interprofissional para um cuidado efetivo e seguro. Interface (Botucatu) [Internet]. 2016 Mar [cited 2017 Jan 25]; 20(56): 185-197. Available http://www.scielo.br/scielo.php?script=sci arttext\&pid=S141432832016000100185\&lng=en. http://dx.doi.org/10.1590/1807-57622014.0092.

Riessman, CK. Narrative Analysis. In: Kelly N, Horrocks C, Milnes K, Roberts B, Robinson D (Eds.), Narrative, memory \& everyday life. Huddersfield, England: University of Huddersfield. 2005. p. 1-7.

Robb G, Stolarek I, Wells S, Bohm G. The state of quality improvement and patient safety teaching in health professional education in New Zealand. N Z Med J. 2017 Oct 27; 130 (1464): 13-24.

Rodrigues MV, Carâp LJ, EI-Warrak LO, Rezende TB. Qualidade e acreditação em saúde. Rio de Janeiro (RJ): Editora FGV, 2011.

Santos MC, Grilo A, Andrade G, Guimarães T, Gomes A. Comunicação em saúde e a segurança do doente: problemas e desafios Rev Port Saúde Pública. 2010; (10): 47- 57. 
Sartori MRA, YAmanaka NMA. Gerenciamneto de protocolos assistenciais e indicadores: resultado e desempenho. In: Fonseca AS, Peterlini FL, Costa DA organizadores. Segurança do Paciente.São Paulo: Martinari; 2014. p.101- 8.

Saupe R, Cutolo LRA, Wendhausen Águeda Lenita Pereira, Benito Gladys Amélia Vélez. Competência dos profissionais da saúde para o trabalho interdisciplinar. Interface [Internet]. 2005 Dec [cited 2017 Jan 24]; 9(18): 521-536. Available from: http://www.scielo.br/scielo.php?script=sci arttext\&pid=S141432832005000300005\&l $\underline{\mathrm{ng}=\mathrm{en}}$.

Silva LD. Segurança do paciente no contexto hospitalar. Rev. Enferm. UERJ. 2012; 20(3): 291-2.

Silverman D. Interpretação de dados qualitativos: métodos para análise de entrevistas, textos e interações. Porto Alegre: Artmed; 2009.

Sousa P. Patient safety: a necessidade de uma estratégia nacional. Acta Médica Portuguesa [Internet]. 2007 [cited 2015 Set 25]; 19(4), 309-17. Available from: http://actamedicaportuguesa.com/revista/index.php/amp/article/view/964/637\%3E

Stake RE. Qualitative case studies. In: Denzin NK, Lincoln YN (editors) The Sage Handbook of Qualitative Research. 3rd ed. Thousand Oaks: Sage Publications, 2005. p. 443-66.

The Joint Commission. The essencial roele of leadership in developing a safety culture. 2017; [cited 03 mar. 2017]. Available from: https://www.jointcommission.org/assets/1/18/SEA 57 Safety Culture Leadership 0 $\underline{317 . p d f}$

Trad Leny A. Bomfim. Grupos focais: conceitos, procedimentos e reflexões baseadas em experiências com o uso da técnica em pesquisas de saúde. Physis [Internet]. 2009 [cited 2017 Nov 24]; 19(3): 777-796. Available from: http://www.scielo.br/scielo.php?script=sci arttext\&pid=S010373312009000300013\&l $\underline{\mathrm{ng}=\mathrm{en}}$.

Tronchin DMR, Freitas GF; Melleiro MM. Avaliação de serviços, qualidade e segurança do paciente no setor de saúde. In: Kurcgant $P$, organizador. Gerenciamento em enfermagem. $3^{\underline{a}}$ ed. Rio de Janeiro (RJ): Guanabara Koogan; 2016. p. $59-73$

Urbanetto JS, Gerhardt LM. Segurança do paciente na tríade assistência ensino pesquisa [Editorial]. Rev Gaúcha Enferm. 2013;34(3):8-9.

VanGeest JB, Cummins DS. An Educational needs assessment for improving patient safety: Results of a national study of physicians and nurses. Chicago, II: National Patient Safety Foundation [Internet]. 2003; [cited 2017 Jan 25]; Available from: http://c.ymcdn.com/sites/www.npsf.org/resource/collection/ABAB3CA8-4E0A-41C5A480-6DE8B793536C/Educational Needs Assessment.pdf 
Ventura MM. O estudo de caso como modalidade de pesquisa. Revista da Sociedade de Cardiologia do Estado do Rio de Janeiro [Internet]. 2007; [cited 2017 Jun 201]; 20(5): $383-386$. Available from: http://sociedades.cardiol.br/soceri/revista/2007 05/a2007 v20 n05 art10.pdf

Vicent C. Segurança do paciente: orientações para evitar eventos adversos. São Caetano do Sul (SP): Yendis; 2009.

Wachter R. Compreendendo a segurança do paciente. $2^{2}$ ed. Porto Alegre: AMGH; 2013.

Walton MM; Barraclough B; Van Staalduinen S; Elliott S. An Educational Approach to Improving Healthcare Safety and Quality. J Evid Based Med [Internet]. 2009; [cited 2015 Oct 01]; 3:136-142. Available from: https://www.ncbi.nlm.nih.gov/pubmed/16719739

Walton MM; Shaw T; Barnet S; Ross J. Developing a national patient safety education framework for Australia. Qual Saf Health Care [Internet]. 2006; [cited 2015 Oct 01]; 15:437-442. Available from: https://www.ncbi.nlm.nih.gov/pmc/articles/PMC2464900/pdf/437.pdf

Wegner W, Silva SC, Kantorski KJC, Predebon CM, Sanches MO, Pedro ENR Educação para cultura da segurança do paciente: Implicações para a formação profissional. Esc. Anna Nery [Internet]. 2016 [cited 2017 Jan 25] ; 20(3): e20160068.

Available

from:

http://www.scielo.br/scielo.php?script=sci arttext\&pid=S141481452016000300212\&l ng=en. Epub June 07, 2016. http://dx.doi.org/10.5935/1414-8145.20160068.

Westbrook JI, Woods A, Rob MI, Dunsmuir WTM, Day RO. Association of Interruptions With an Increased Risk and Severity of Medication Administration Errors. Arch Intern Med. 2010;170(8):683-690.

World Health Organization (WHO). The World Alliance for Patient Safety [Internet]. Geneva: WHO, 2004. [cited 2015 Oct. 11]. Available from: http://www.who.int/patientsafety-/worldalliance/en/

World Health Organization (WHO). The World Alliance for Patient Safety. Forward Program 2006- 2007 [Internet]. Geneva: WHO, 2006 [cited 2017 Ago 11]. Available from:

http://www.who.int/patientsafety/information centre/WHO EIP HDS PSP 2006.1.pdf

World Health Organization (WHO). Patient safety solution preamble. [Internet]. Geneva: WHO, 2007. [cited 2015 Oct. 11]. Available from:

http://www.who.int/patientsafety/solution/patient-safety/Preamble.pdf

World Health Organization (WHO). The World Alliance for Patient Safety. Forward Program 2008- 2009 [Internet]. Geneva: WHO, 2008 [cited 2015 Oct. 11]. Available from:http://www.who.int/patientsafety/information centre/reports/Alliance Forward P rogramme 2008.pdf 
World Health Organization (WHO). Conceptual framework for the international classification for patient safety. Version 1.1. Final Technical Report [Internet]. Geneva: WHO, 2009a [cited 2015 Oct. 11]. Available from: www.who.int/patientsafety/taxonomy/icps full report.pdf

World Health Organization (WHO). Guidelines on hand hygiene in health care [Internet]. Geneva: WHO, 2009b [cited 2017 Ago. 18]. Available from: http://apps.who.int/iris/bitstream/10665/44102/1/9789241597906 eng.pdf

World Health Organization (WHO). Surgical safety checklist. Safe surgery saves lives. [Internet]. Geneva: WHO, 2009c [cited 2017 Ago. 18]. Available from: http://apps.who.int/iris/bitstream/10665/44186/1/9789241598590 eng.pdf

World Health Organization (WHO). Framework for action on interprofessional education \& collaborative practice. [Internet]. Geneva: WHO, 2010 [cited 2017 Jun. 18]. Available from: http://apps.who.int/iris/bitstream/10665/70185/1/WHO HRH HPN 10.3 eng.pdf?ua=1

World Health Organization (WHO). Patient safety curriculum guide: multi-professional edition [Internet]. Geneva: WHO, 2011. [cited 2015 Oct. 01]. Available from: http://whalibdoc.who.int/publications/2011/9789241501958 eng.pdf

World Health Organization (WHO). Medication Without Harm. Global Patient Safety Challenge on Medication Safety. [Internet]. Geneva: WHO, 2017 [cited 2017 Ago. 18]. Available from: http://apps.who.int/iris/bitstream/10665/255263/1/WHO-HIS-SDS-2017.6eng.pdf?ua $=1 \& u a=1$

Yin RK. Estudo de caso planejamento e métodos. 5ed. Porto Alegre: Bookman, 2015.

Yin RK. Pesquisa qualitativa do início ao fim. Porto Alegre: Penso, 2016.

Yoshikawa JM; Sousa BEC de; Peterlini MAS; Kusahara DM; Pedreira MLG; Avelar AFM. Compreensão de alunos de cursos de graduação em enfermagem e medicina sobre segurança do paciente. Acta paul. enferm. [Internet]. 2013 [cited 2015 Oct 01]; 26(1): 21-29. Available from: http://www.scielo.br/scielo.php?script=sci arttext\&pid=S0103-21002013000100005

Zimmermann K, Holzinger IB, Ganassi L, Esslinger P, Pilgrim S, Allen M et.al. BMC Medical Education. 2015; 15:189. 

APÊNDICES

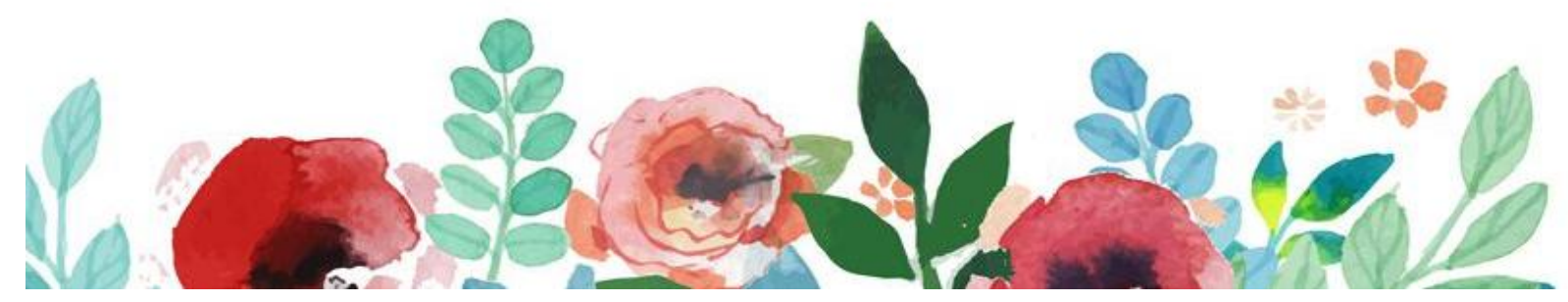





\section{APÊNDICE A - Termo de Consentimento Livre e Esclarecido}

Eu, Ana Claudia Alcântara Garzin, doutoranda do Programa de Pós-graduação em Gerenciamento em Enfermagem da Escola de Enfermagem da Universidade de São Paulo, orientanda da Prof $^{a}$ Dr $^{a}$ Marta Maria Melleiro, venho convidá-lo(a) a participar da pesquisa em desenvolvimento intitulada SEGURANÇA DO PACIENTE NA FORMAÇÃO DOS PROFISSIONAIS DE SAÚDE, a qual busca compreender a percepção de alunos de graduação dos cursos de enfermagem, medicina, fisioterapia, farmácia, biomedicina, terapia ocupacional, psicologia e nutrição acerca do ensino da temática segurança do paciente em uma instituição de ensino superior privada. Este estudo se justifica, pois o tema envolve todos os profissionais que prestam assistência ao paciente nas instituições de saúde.

Para tanto, solicito sua anuência para realizar uma entrevista gravada, que compreende a coleta de dados, conduzida pela própria pesquisadora no local e momento de sua escolha, com a duração aproximada de 30 minutos, cujo conteúdo será empregado, apenas, para a realização do estudo. Esclareço que os resultados da pesquisa poderão ser apresentados em eventos ou publicados em revistas científicas sem a sua identificação; o sigilo das informações e o anonimato serão garantidos.

O estudo não acarretará em despesas financeiras ou danos diretos; contudo há a possibilidade de desconforto em função do tempo despendido por ocasião da entrevista. A pesquisadora informa ainda que, caso necessário, haverá indenização pertinente ao participante em decorrência de algum prejuízo advindo da pesquisa.

A sua participação no estudo é totalmente voluntária, podendo deixá-la a qualquer momento, sem nenhum prejuízo. Caso aceite participar, solicito a sua assinatura nas duas vias deste documento, sendo que uma delas Ihe será entregue e a outra permanecerá com a pesquisadora. A conclusão desta pesquisa está prevista para outubro de 2017.

Desde já agradeço a sua colaboração e coloco-me à disposição para quaisquer esclarecimentos durante todas as etapas da pesquisa. Seguem meus dados para contato: celular (11) 97515.4374; e-mail: anagarzin@usp.br.

Caso você tenha alguma consideração ou dúvida sobre a ética da pesquisa, entre em contato com o Comitê de Ética em Pesquisa da Escola de Enfermagem da USP - SP: av. Dr. Enéas de Carvalho Aguiar, 419 - Cerqueira César - CEP 05403-000 - São Paulo - SP; tel.: (11) 3061.8858; e-mail:cepee@usp.br ou com o Centro Universitário São Camilo; Rua Raul Pompeia, 144 - Pompeia - São Paulo - SP- CEP: 05025-010; tel.: (11) 3465-2669; e-mail: coep@saocamilo-sp.br.

Esta pesquisa atende a todas as especificações da Resolução 466, de 12 de dezembro de 2012, que aprova as diretrizes e normas regulamentadoras de pesquisa envolvendo seres humanos.

São Paulo, de de 2016.

Participante da pesquisa 


\section{APÊNDICE B - Roteiro para a realização das entrevistas com discentes}

Caracterização do sujeito de pesquisa

Sexo: $F(\quad) M(\quad)$

Idade:

Curso:

Semestre:

Questões norteadoras

$\checkmark$ Como você percebe a temática segurança do paciente no ensino de graduação?

$\checkmark$ Descreva-me em qual momento do curso de graduação você teve contato com a temática segurança do paciente?

$\checkmark \quad$ Frente aos 11 tópicos sugeridos pela OMS e apresentados à você nessa entrevista, como você acredita que isso poderia ser inserido na sua formação?

Observações da pesquisadora: 
APÊNDICE C - Material ilustrativo elaborado pela pesquisadora a partir do Guia Curricular de Segurança do Paciente: edição Multiprofissional

$$
\begin{gathered}
11 \text { TÓPICOS } \\
\text { DO GUIA CURRICULAR } \\
\text { MULTIPROFISSIONAL DE } \\
\text { SECURANGGA DO PACIENTE } \\
\text { DA ORGANIZACJ̈O } \\
\text { MUNDIAL DA SAÚDE }
\end{gathered}
$$

World Health Organization (WHO). Patient safety curriculum guide: multi-professional edition. 2011. Disponivel em: http//whqlibdoc. who.int/publications/2011/9789241501958_eng.pdf 


\section{0 que é segurança do paciente?}

Princípios e definições básicos sobre a temática segurança do paciente, necessários a todos os profissionais da saúde.

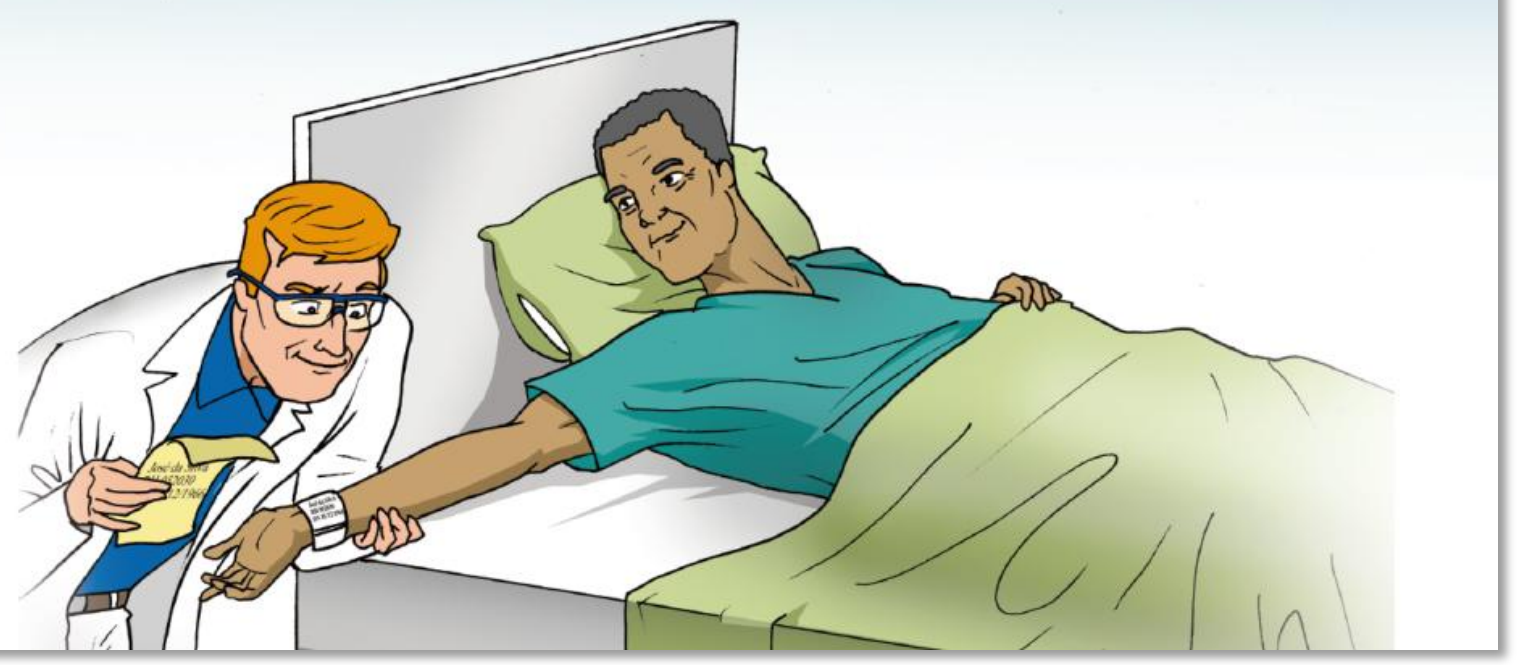

\section{Por que a aplicação de fatores humanos é importante para a segurança do paciente?}

Inter-relação entre as pessoas e o ambiente de trabalho, a engenharia, o sistema e os processos relacionados ao fator humano e seu impacto na segurança do paciente.

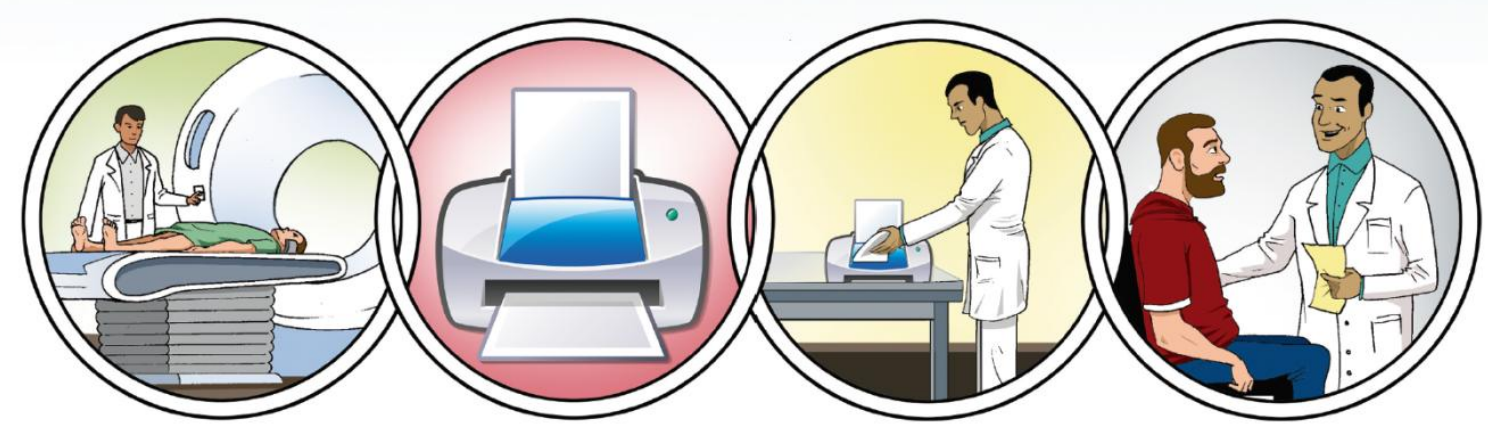




\section{Compreender os sistemas e o efeito da complexidade no cuidado ao paciente.}

Complexidade do sistema de saúde que integra departamentos, serviços, unidades, além da prática assistencial e suas relações nas organizações.

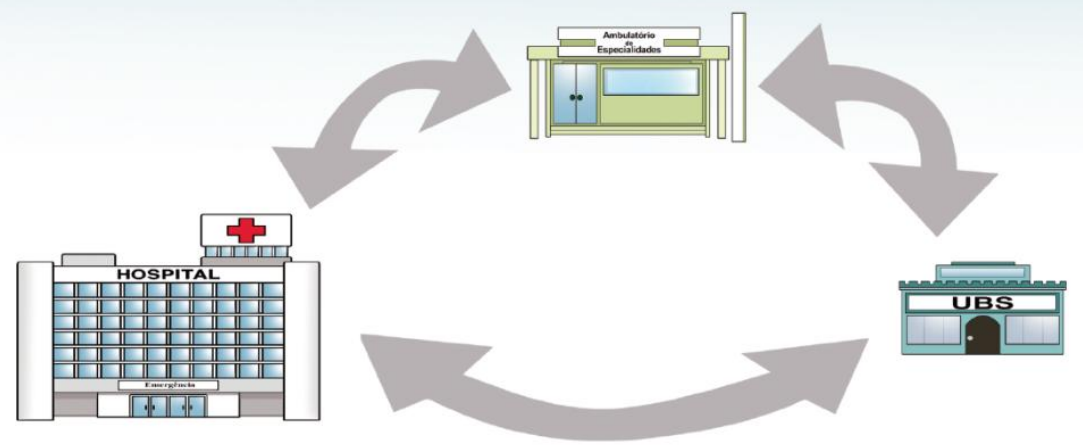

\section{Ser um participante de uma equipe eficaz.}

Benefícios de atuar em equipes multidisciplinares para a melhoria da assistência e para a redução de erros, bem como a importância da comunicação entre os membros da equipe, incluindo o paciente.

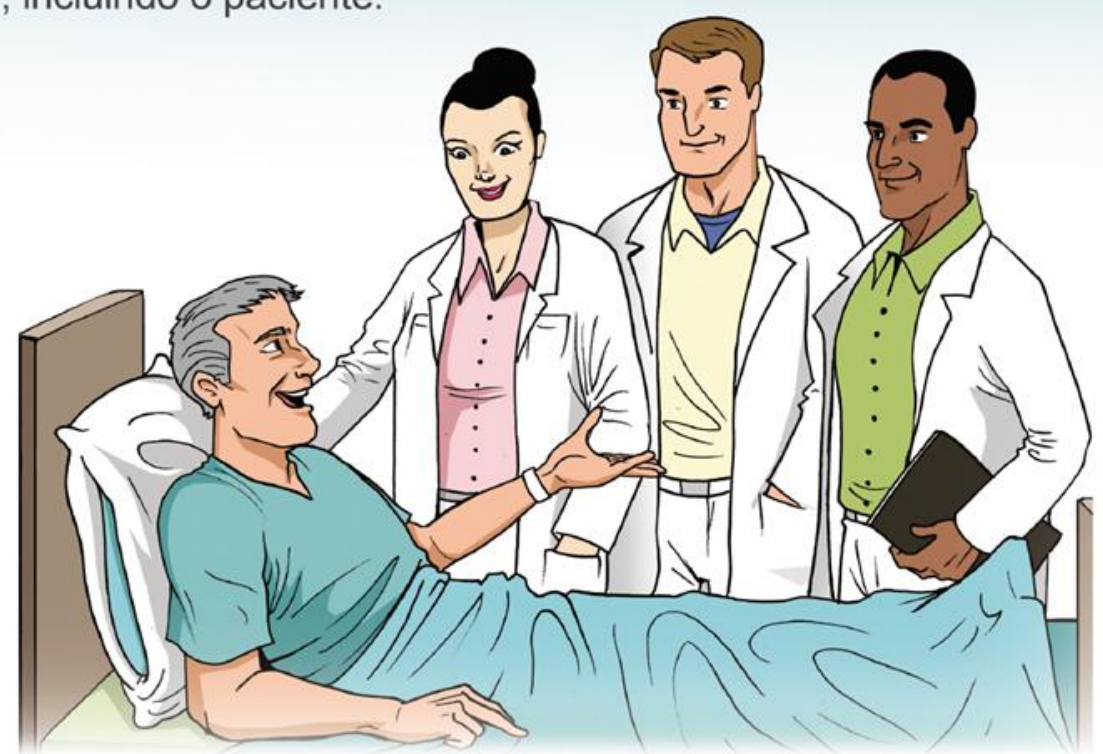




\section{Aprender com os erros para evitar danos.}

Importância da notificação de incidentes para aprender e compreender que os erros na assistência à saúde fornecem a base para a realização de melhorias e implementação de sistemas e processos mais eficazes.

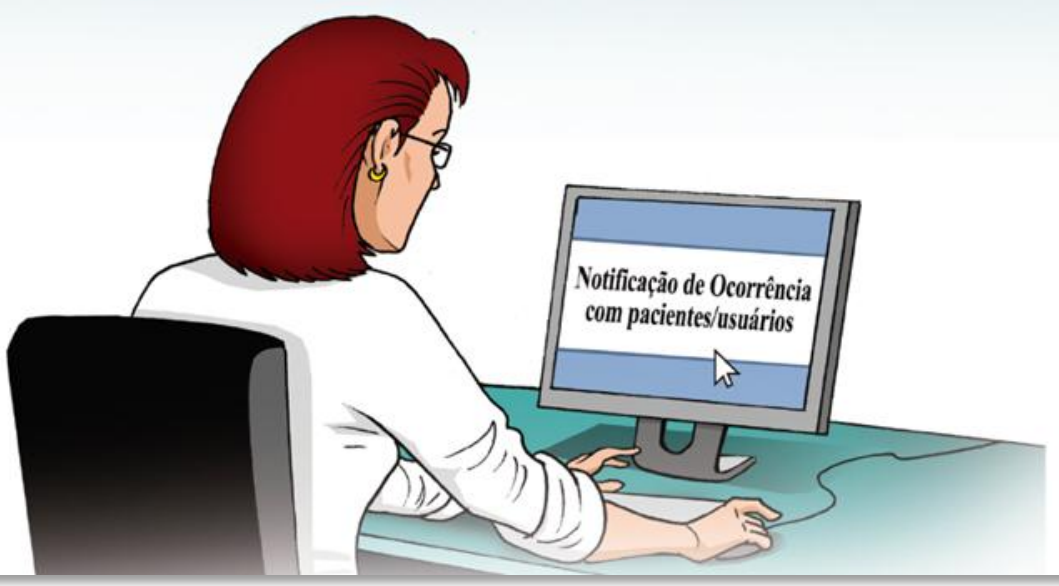

\section{Entender e gerenciar o risco clínico.}

Identificação das circunstâncias que colocam os pacientes em risco e desenvolvimento de ações para evitá-los ou controlá-los.

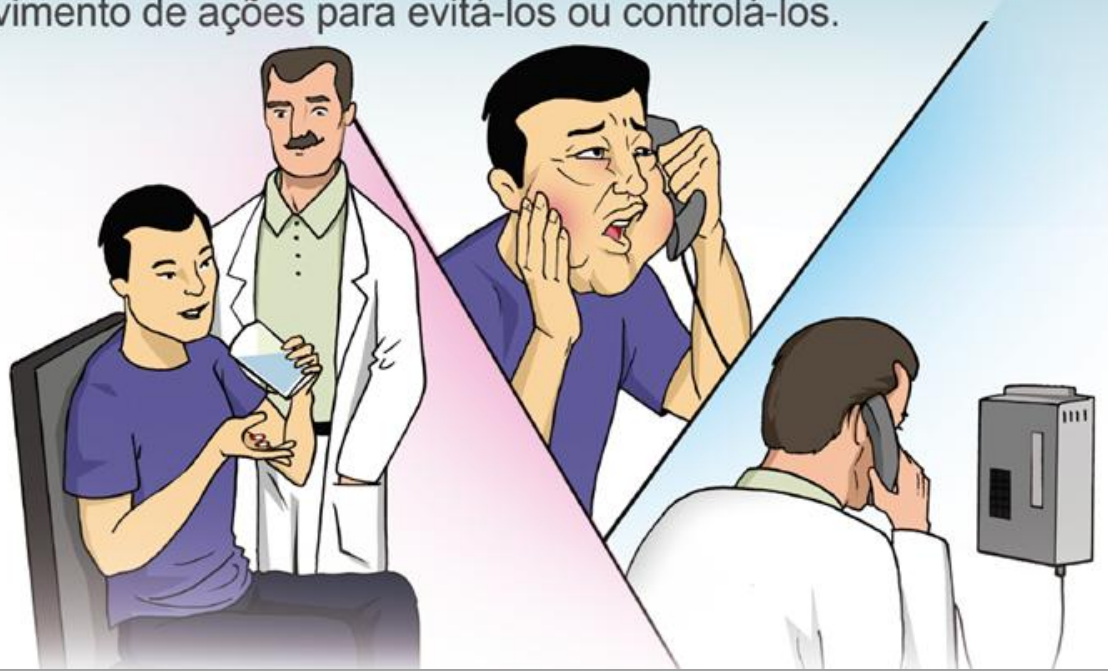


7 Utilizar métodos de melhoria da qualidade para aprimorar o cuidado. Incorporação dos principais conceitos da melhoria da qualidade e suas ferramentas, na prática clínica, por meio da identificação e avaliação de processos mensuráveis da assistência à saúde.

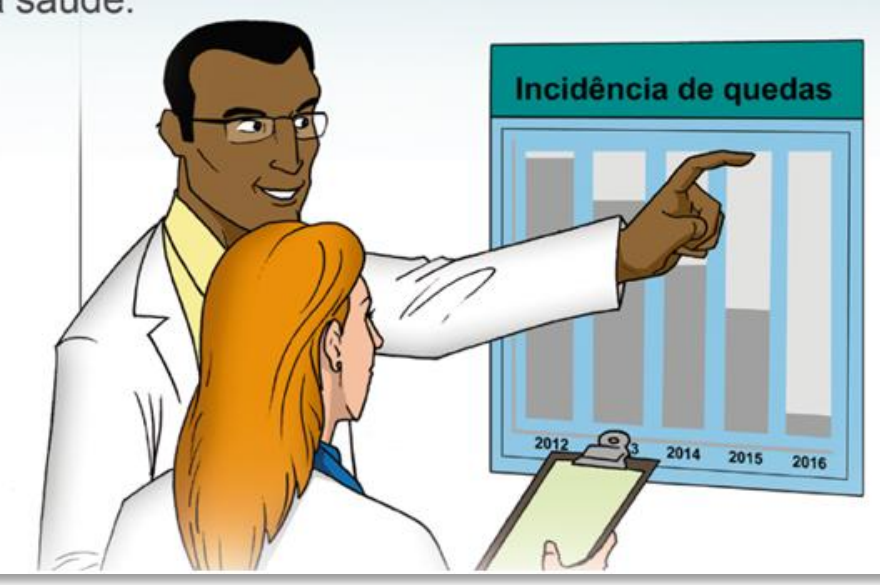

\section{Interação com pacientes e cuidadores.}

Importância da equipe assistencial incluir o paciente e/ou seu cuidador como elemento fundamental para a segurança dos cuidados à saúde.

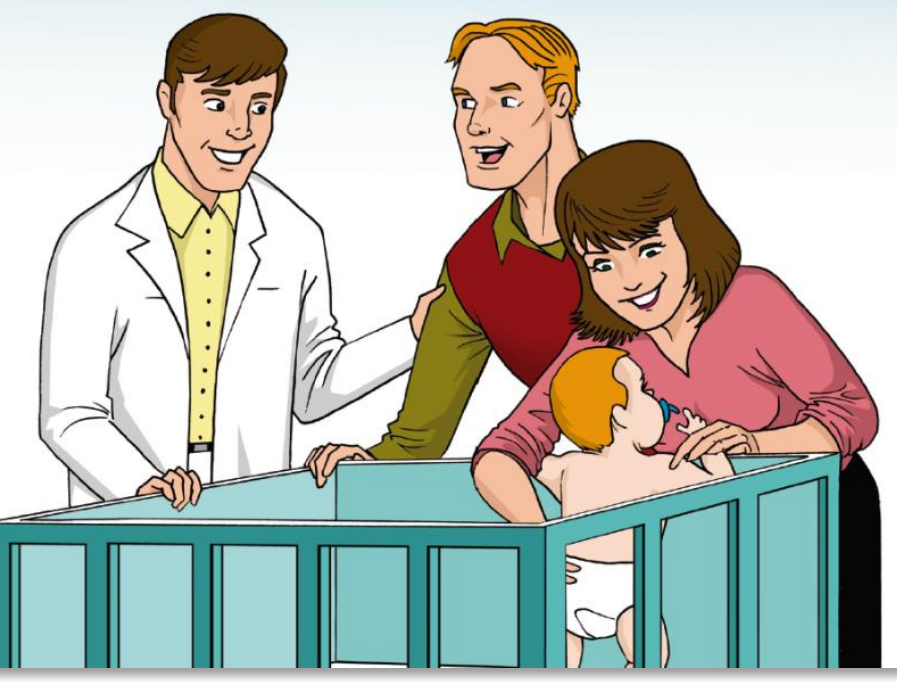




\section{Prevenção e controle de infecção.}

Principais causas e tipos de infecções associados aos procedimentos empregados na assistência à saude e as medidas adequadas para prevenir a transmissão.

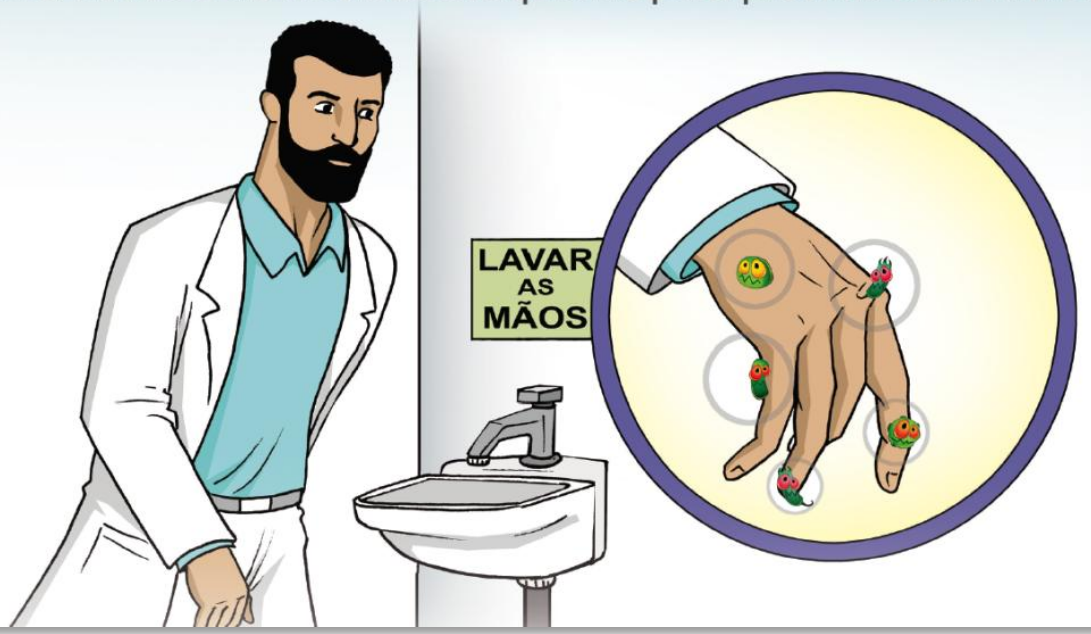

\section{Segurança do paciente e procedimentos invasivos.}

Os benefícios de usar listas de verificação ou protocolos para evitar erros envolvendo pacientes, locais e procedimentos errados. 


\section{Melhorar a segurança do processo de medicação.}

Vulnerabilidade dos pacientes aos erros em qualquer uma das etapas envolvidas na prescrição, dispensação e administração de medicamentos.

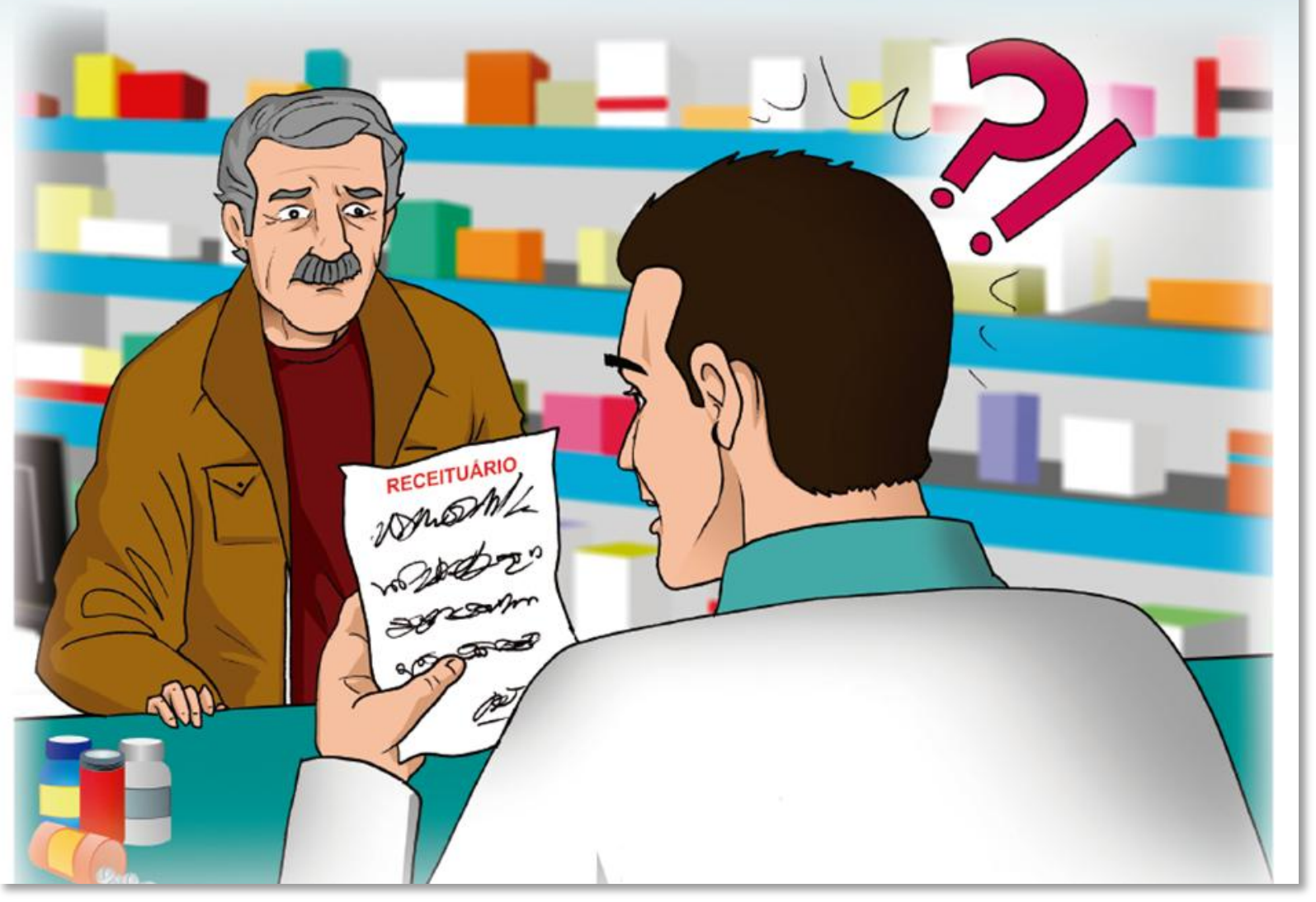



ANEXO

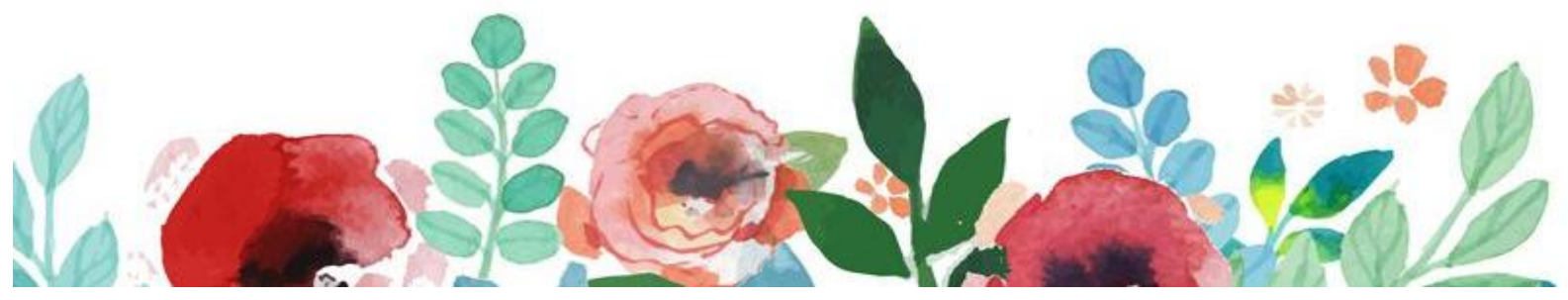





\section{ANEXO 1 - Aprovação pelo Comitê de Ética em Pesquisa - Instituição Proponente}

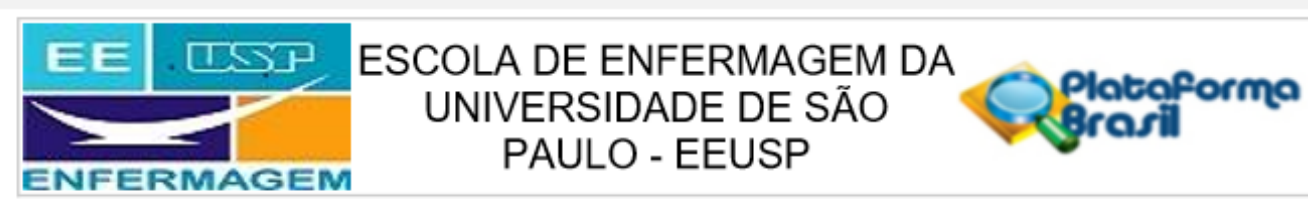

\section{PARECER CONSUBSTANCIADO DO CEP}

\section{DADOS DO PROJETO DE PESQUISA}

Título da Pesquisa: PERCEPC̣ÃO DA TEMÁTICA SEGURANÇA DO PACIENTE NA FORMAC̣ÃO DOS PROFISSIONAIS DE SAÚDE

Pesquisador: ANA CLAUDIA ALCANTARA GARZIN

Área Temática:

Versão: 2

CAAE: 51279815.1 .0000 .5392

Instituição Proponente: Escola de Enfermagem da Universidade de São Paulo - EEUSP

Patrocinador Principal: Financiamento Próprio

\section{DADOS DO PARECER}

Número do Parecer: 1.400 .152

Apresentação do Projeto:

Este estudo tem por objetivo compreender a percepção de discentes de graduação de uma instituição de ensino superior, lotados nos cursos de enfermagem, medicina, fisioterapia, farmácia, nutrição, terapia ocupacional, biomedicina e psicologia acerca do ensino da temática segurança do paciente. É uma pesquisa qualitativa, com delineamento exploratório-descritivo, cuja coleta de dados será realizada por meio de entrevista semi estruturada.

\section{Objetivo da Pesquisa:}

Compreender a percepção de discentes de graduação de uma instituição de ensino superior, lotados nos cursos de enfermagem, medicina, fisioterapia, farmácia, nutrição, terapia ocupacional, biomedicina e psicologia acerca do ensino da temática segurança do paciente.

\section{Avaliação dos Riscos e Benefícios:}

Segundo a pesquisadora, o estudo não acarretará em despesas financeiras ou danos diretos; contudo há a possibilidade de desconforto em função do tempo despendido por ocasião da entrevista. E os benefícios estão voltados em compreender a percepção de alunos de graduação dos cursos da saúde acerca do ensino da temática segurança do paciente em uma instituição de ensino superior privada, uma vez que este assunto envolve todos os profissionais que prestam assistência ao paciente nas instituições de saúde.

Endereço: Av. Dr Enéas de Carvalho Aguiar, 419

Bairro: Cerqueira Cesar

CEP: $05.403-000$

UF: SP

Município: SAO PAULO

Telefone: (11)3061-8858

E-mail: cepee@usp.br 


\section{EE पSSP ESCOLA DE ENFERMAGEM DA UNIVERSIDADE DE SÃO PAULO - EEUSP \\ ENFERMAGEM}

Continuação do Parecer: 1.400 .152

\section{Comentários e Considerações sobre a Pesquisa:}

Pesquisa relevante na área de saúde, pela temática atual, e importante para o ensino /aprendizado do aluno de graduação.

Considerações sobre os Termos de apresentação obrigatória:

Todos os termos foram apresentados de forma clara e objetiva.

Recomendações:

Não há.

Conclusões ou Pendências e Lista de Inadequaçōes:

Não há pendências ou inadequações.

Considerações Finais a critério do CEP:

- Este CEP informa a necessidade de registro dos resultados parciais e finais na Plataforma Brasil;

- Esta aprovação não substitui a autorização da instituição coparticipante, antes do início da coleta de dados.

Este parecer foi elaborado baseado nos documentos abaixo relacionados:

\begin{tabular}{|l|l|c|l|c|}
\hline \multicolumn{1}{|c|}{ Tipo Documento } & \multicolumn{1}{|c|}{ Arquivo } & Postagem & \multicolumn{1}{c|}{ Autor } & Situação \\
\hline $\begin{array}{l}\text { Informações Básicas } \\
\text { do Projeto }\end{array}$ & $\begin{array}{l}\text { PB_INFORMAÇOES_BASICAS_DO_P } \\
\text { ROJETO 629747.pdf }\end{array}$ & $\begin{array}{c}24 / 12 / 2015 \\
15: 23: 21\end{array}$ & & Aceito \\
\hline Outros & Carta_Autorizaca_CPQ_CUSC.pdf & $24 / 12 / 2015$ & \\
& & $15: 21: 42$ & $\begin{array}{l}\text { ANA CLAUDIA } \\
\text { ALCANTARA } \\
\text { GARZIN }\end{array}$ & Aceito \\
\hline $\begin{array}{l}\text { Projeto Detalhado / } \\
\text { Brochura } \\
\text { Investigador }\end{array}$ & Projeto_Doutorado.docx & $\begin{array}{c}24 / 12 / 2015 \\
13: 08: 20\end{array}$ & $\begin{array}{l}\text { ANA CLAUDIA } \\
\text { ALCANTARA } \\
\text { GARZIN }\end{array}$ & Aceito \\
\hline $\begin{array}{l}\text { TCLE / Termos de } \\
\text { Assentimento / } \\
\text { Justificativa de } \\
\text { Ausência }\end{array}$ & TCLE.docx & $24 / 12 / 2015$ & $\begin{array}{l}\text { ANA CLAUDIA } \\
\text { ALCANTARA } \\
\text { GARZIN }\end{array}$ & Aceito \\
\hline Folha de Rosto & FolhaderostoPlataformaBrasil.pdf & $24 / 11 / 2015$ & \\
& & $14: 02: 31$ & $\begin{array}{l}\text { ANA CLAUDIA } \\
\text { ALCANTARA } \\
\text { GARZIN }\end{array}$ & Aceito \\
\hline
\end{tabular}

Situação do Parecer:

Aprovado

Necessita Apreciação da CONEP:

Não

$$
\begin{aligned}
& \text { Endereço: Av. Dr Enéas de Carvalho Aguiar, } 419 \\
& \text { Bairro: Cerqueira Cesar CEP: } 05.403-000 \\
& \text { UF: SP Município: SAO PAULO } \\
& \text { Telefone: (11)3061-8858 } \\
& \text { E-mail: cepee@usp.br }
\end{aligned}
$$

